UNIVERSIDADE DE SÃO PAULO

ESCOLA DE COMUNICAÇÕES E ARTES

VERÔNICA REIS CRISTO

A comunicação integrada em negócios sociais:

um estudo aplicado do caso Quintessa

São Paulo

2019 
VERÔNICA REIS CRISTO

\section{A comunicação integrada em negócios sociais: um estudo aplicado do caso Quintessa}

\section{Versão original}

Dissertação apresentada à Escola de Comunicações e Artes da Universidade de São Paulo para obtenção do título de Mestre em Ciências da Comunicação.

Área de Concentração: Interfaces Sociais da Comunicação - Políticas e Estratégias de Comunicação.

Orientadora: Profa. Dra. Margarida Maria Krohling Kunsch

São Paulo 
Nome: CRISTO, Verônica Reis

Título: "A comunicação integrada em negócios sociais: um estudo aplicado do caso Quintessa"

Dissertação apresentada à Escola de Comunicações e Artes da Universidade de São Paulo para obtenção do título de Mestre em Ciências da Comunicação.

Aprovado em:

Banca examinadora

Profa. Dra.

Instituição:

Julgamento:

Assinatura:

Profa. Dra.

Instituição:

Julgamento:

Assinatura:

Profa. Dra.

Instituição:

Julgamento:

Assinatura: 


\section{AGRADECIMENTOS}

Agradeço a Deus,

por tudo que sou e tudo que tenho.

Ao meu marido Andrei,

por ficar ao meu lado durante toda esta jornada.

À minha mãe e ao meu pai,

pelo incentivo e compreensão.

Aos brothers Vanessa e Rodolfo,

pelo carinho e toda a torcida!

À Escola de Comunicações e Artes da USP,

que se tornou minha segunda casa.

\section{Ao PPGCOM,}

pela acolhida à pesquisa e pelos muitos ensinamentos.

Às colegas da ECA, Ju, Laís e Key,

cujo apoio foi tão importante!

Ao Quintessa, seus profissionais e empreendedores sociais

que tornaram esta dissertação possível.

À minha orientadora, Margarida Maria Krohling Kunsch, a quem admiro mais a cada dia que passa. 


\section{RESUMO}

\section{CRISTO, V. R. A comunicação integrada em negócios sociais: um estudo aplicado do caso}

Quintessa. 2019. 186 f. Dissertação (Mestrado em Ciências da Comunicação) - Escola de Comunicações e Artes, Universidade de São Paulo, São Paulo, 2019.

O objetivo desta dissertação foi analisar o gerenciamento da comunicação para acelerar negócios sociais - organizações que têm sido tema de estudos de outros campos do saber e têm conquistado projeção crescente na contemporaneidade pela sua atuação em problemas sociais. Considera-se o estudo relevante na medida em que permite discutir o valor estratégico da comunicação para novos modelos organizacionais, configurando-se como uma nova dimensão de estudos para o campo da comunicação organizacional. O estudo visou contextualizar negócios sociais, abordando aspectos ligados aos seus conceitos e características, sua articulação com o desenvolvimento sustentável e o ecossistema de negócios sociais. Uma releitura de marcos teóricos da comunicação organizacional, em particular da comunicação integrada, permitiu aproximar conhecimentos do campo ao caso em estudo. Trata-se de pesquisa qualitativa que emprega o método de estudo de caso envolvendo a aceleradora de negócios sociais Quintessa, além da coleta de dados em três negócios sociais: 4YOU2, Banca do Bem e E-Moving. Por meio de um conjunto de categorias, buscou-se refletir sobre a comunicação dos negócios sociais em um contexto de desenvolvimento sustentável; analisar a comunicação dos negócios sociais sob uma filosofia e política de comunicação integrada; e identificar, em nível estratégico, tático e operacional, práticas e técnicas de comunicação adotadas pelos negócios sociais. Constatou-se que a comunicação é pouco abordada nos programas de aceleração, sendo compreendida pelos empreendedores, no entanto, pelo seu valor estratégico para o negócio. Ficou evidente também a necessidade de maior clareza sobre o conceito de negócios sociais e negócios de impacto social, tanto entre os atores do ecossistema quanto na comunicação com os públicos. Observou-se ainda a imprecisão quanto ao lugar dos negócios sociais no contexto de desenvolvimento sustentável, sendo preciso amadurecer a comunicação dos Objetivos de Desenvolvimento Sustentável pelos negócios sociais, no sentido de fortalecer alianças intersetoriais para alavancar o impacto social. Por fim, notou-se o predomínio da dimensão da comunicação mercadológica nos negócios sociais, sob uma lógica de mercado ligada, sobretudo, a aspectos táticos e operacionais.

PALAVRAS-CHAVE: Comunicação. Comunicação integrada. Negócios sociais. Sustentabilidade. 


\begin{abstract}
CRISTO, V. R. Integrated communication at social enterprises: an applied study of the

Quintessa case. 2019. $186 \mathrm{f}$. Thesis (Master's in Communications Sciences) - Escola de Comunicações e Artes, Universidade de São Paulo, São Paulo, 2019.

The purpose of this thesis was to analyze the management of communications to accelerate social enterprises growth. These organizations have been the subject of studies in different fields of knowledge and have increased their projection in today's society for their performance regarding social problems. This study is considered relevant because it discusses the strategic value of communication applied to new organizational models, configuring itself as a new dimension of studies for organizational communication. This study consisted of a brief contextualization of social enterprises, addressing aspects related to their concepts and characteristics, its articulation with sustainable development and the social enterprises' ecosystem. A reinterpretation of theoretical frameworks of organizational communication, mainly of integrated communication, allowed us to associate the field's references to our case study. This is a qualitative research which employs the case study method, regarding the accelerator for social enterprises Quintessa, as well as data collected from three accelerated enterprises: 4YOU2, Banca do Bem, and E -Moving. Through a set of categories, the communication of social enterprises was analyzed in a context of sustainable development; social enterprises communication was evaluated under an integrated communication's philosophy and policy; and their communication practices and techniques were identified at a strategic, tactical, and operational level. It was found that communications are not often approached in acceleration programs, despite entrepreneurs acknowledging its strategic value for businesses. It was also evident that greater clarity is required regarding the concept of social enterprises and social impact enterprises among ecosystem actors and strategic audiences. The place of social businesses in a context of sustainable development is also not clear. The communication of the Sustainable Development Goals by social enterprises needs to be more efficient in order to strengthen intersectoral alliances and, therefore, increase social impact. Finally, there was a predominance of marketing communication in social enterprises, associated with tactical and operational aspects.
\end{abstract}

KEYWORDS: Communication. Integrated organizational communication. Social enterprises. Sustainability. 


\section{LISTA DE FIGURAS}

Figura 1 - Sequência lógica do estudo............................................ 13

Figura 2 - Procedimentos para a análise de conteúdo..................................23

Figura 3 - Classificação dos negócios sociais, conforme lógica de atuação...................36

Figura 4 - Escala de negócios híbridos ........................................... 37

Figura 5 - Objetivos de Desenvolvimento Sustentável (ODS) .........................40

Figura 6 - Tipo de suporte oferecido aos empreendedores por organizações de apoio aos

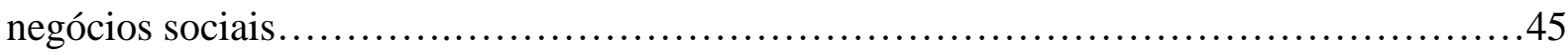

Figura 7 - Modelo de avaliação de programas de aceleração.............................51

Figura 8 - Comunicação integrada.............................................66

Figura 9 - Árvore da comunicação..................................................69

Figura 10 - Linha do tempo: ano de fundação das organizações de apoio aos negócios

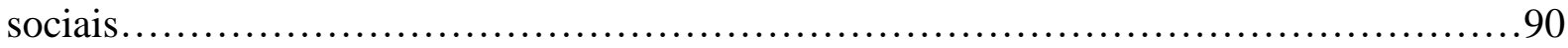

Figura 11 - Noite dos mentores do Quintessa no CIVI-CO..............................93

Figura 12 - Matriz em construção para estudos da comunicação integrada em negócios sociais

\section{LISTA DE GRÁFICOS}

Gráfico 1 - Classificação dos negócios acelerados pelo Quintessa por segmento de atuação.................................................................. 110

Gráfico 2 - Classificação dos negócios acelerados pelo Quintessa de acordo com os ODS 


\section{LISTA DE QUADROS}

Quadro 1 - Fatores para a classificação de empreendimentos sociais.......................35

Quadro 2 - Atores-chave do ecossistema de negócios sociais..........................45

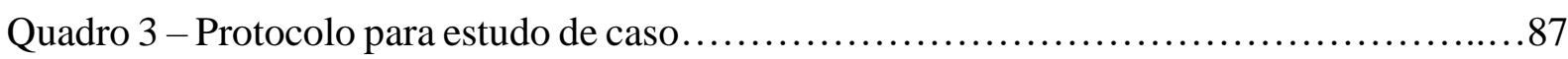

Quadro 4 - Tipos, objetivos, dependência e expectativas de relacionamento do Quintessa com

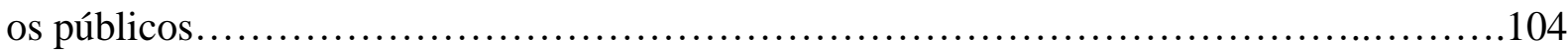

Quadro 5 - Quadro-síntese do método de análise de conteúdo...........................116

Quadro 6 - Categoria 1: A sustentabilidade dos negócios sociais e os negócios sociais

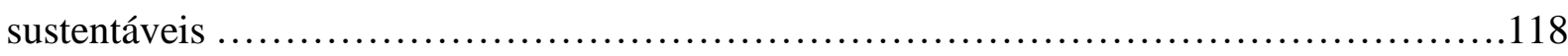

Quadro 7 - Categoria 2: A comunicação na aceleração de negócios sociais..................119

Quadro 8 - Categoria 3: A filosofia da comunicação integrada em negócios sociais.........120

Quadro 9 - Classificação de empreendimentos sociais aplicado a E-Moving, 4YOU2 e Banca do Bem 130

Quadro 10 - Proposta para a classificação de fatores da comunicação integrada em negócios sociais.

Quadro 11 - Classificação dos negócios acelerados pelo Quintessa, em termos de contribuição aos ODS. 


\section{SUMÁRIO}

1 INTRODUÇÃO

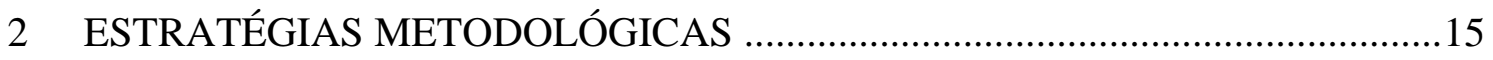

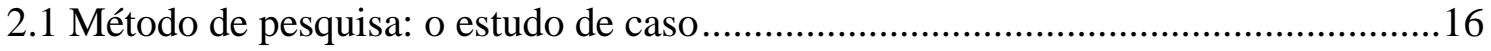

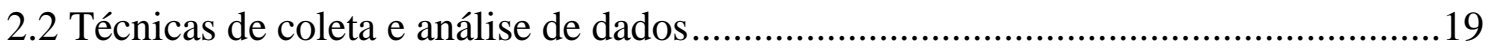

3 DA SUSTENTABILIDADE CORPORATIVA AOS NEGÓCIOS SOCIAIS .......25

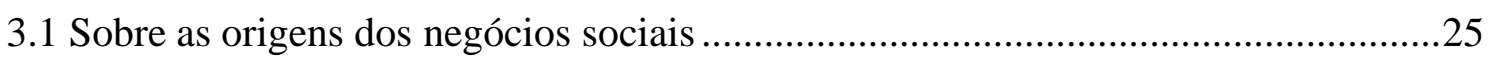

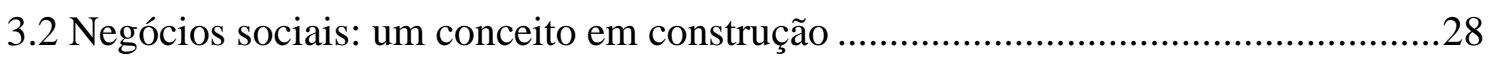

3.3 Mudando a forma de fazer negócios: os negócios híbridos ....................................32

3.4 Negócios sociais e os Objetivos de Desenvolvimento Sustentável (ODS) ................38

3.5 O ecossistema de negócios sociais no Brasil .............................................................4

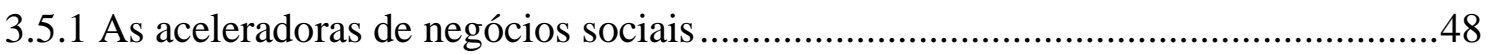

3.6 Desafios para os negócios sociais na contemporaneidade......................................51

4 A COMUNICAÇÃO EM NEGÓCIOS SOCIAIS .............................................56

4.1 A comunicação integrada em interface com os negócios sociais ...............................56

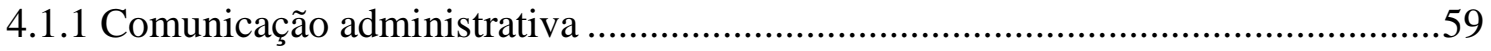

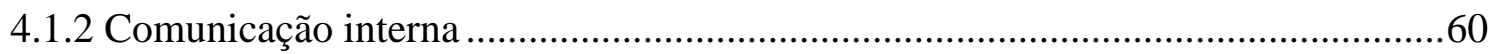

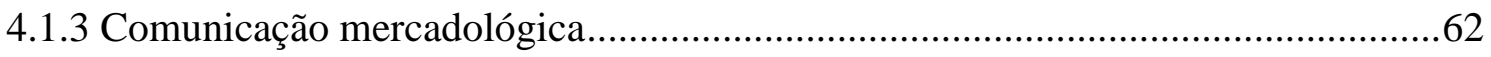

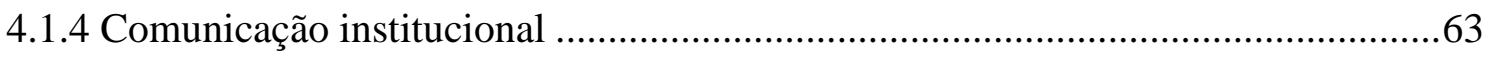

4.2 Políticas e estratégias na gestão da comunicação dos negócios sociais ....................67

4.3 Classificação de públicos e o ecossistema de negócios sociais..................................72

4.4 Comunicação para a sustentabilidade: uma contribuição para a comunicação dos

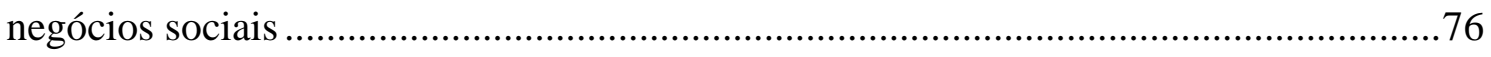

4.5 Negócios sociais: novas perspectivas para as relações públicas comunitárias...........81

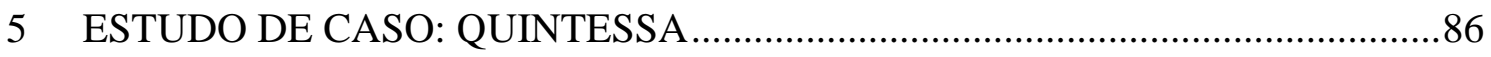

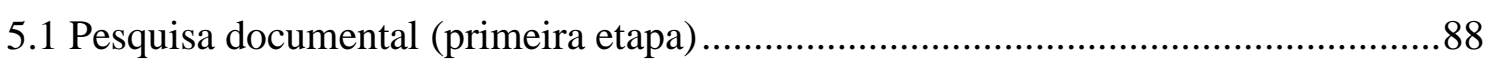

5.2 Análise descritiva da pesquisa documental: perfil institucional do Quintessa ..........89

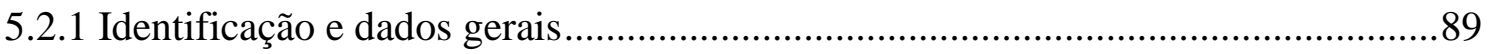




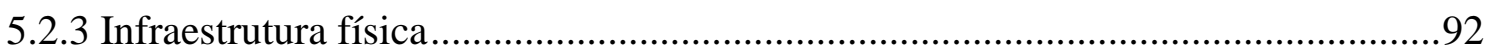

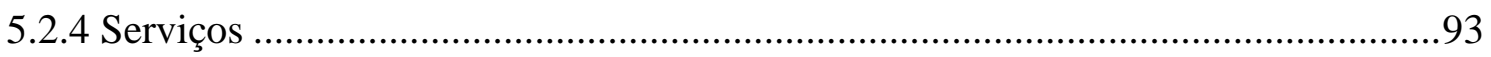

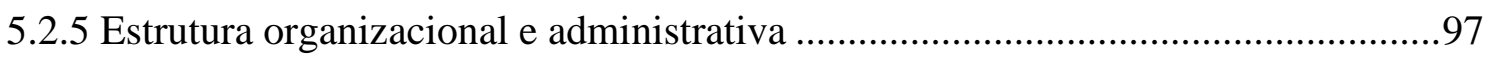

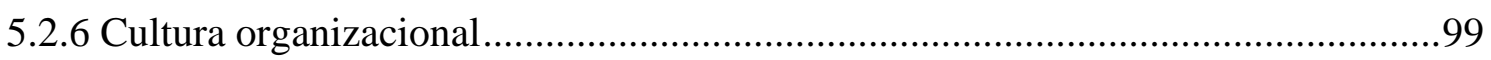

5.3 Entrevistas em profundidade com o Quintessa (segunda etapa) ...........................100

5.4 Análise descritiva da comunicação do Quintessa...................................................101

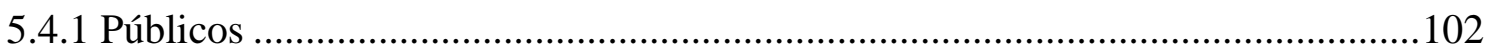

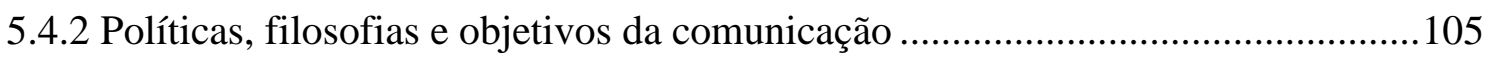

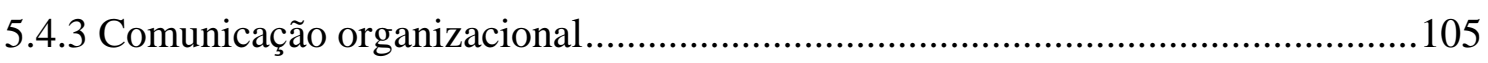

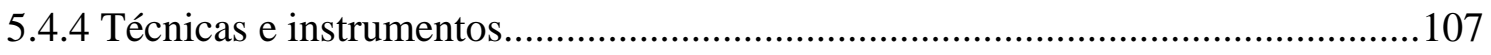

5.4.5 Mensuração e avaliação de resultados ...............................................................108

5.5 Entrevistas com os negócios acelerados (terceira etapa)......................................109

5.5.1 Negócios sociais selecionados para o estudo de caso............................................111

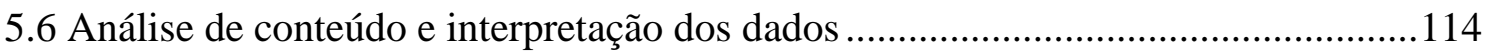

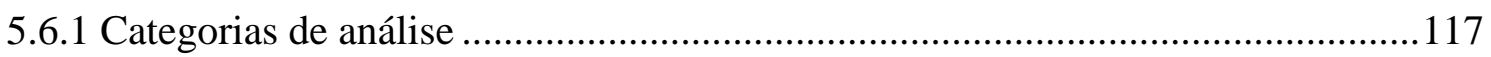

5.6.2 Quadros-resumo da construção progressiva das categorias de análise..................118

5.6.3 Categoria 1: A sustentabilidade dos negócios sociais e os negócios sociais

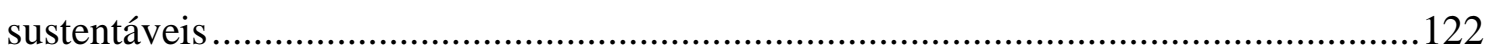

5.6.4 Categoria 2: A comunicação na aceleração de negócios sociais ..........................132

5.6.5 Categoria 3: A filosofia da comunicação integrada em negócios sociais.............139

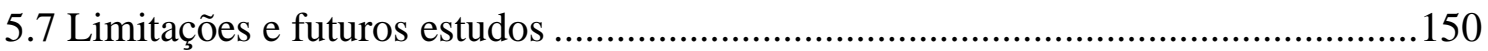

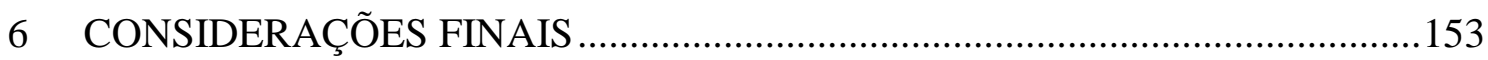

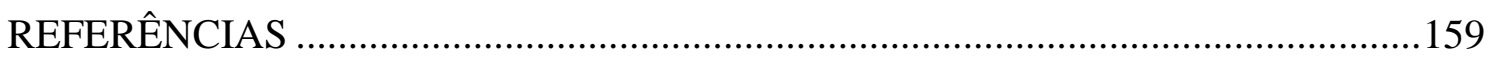

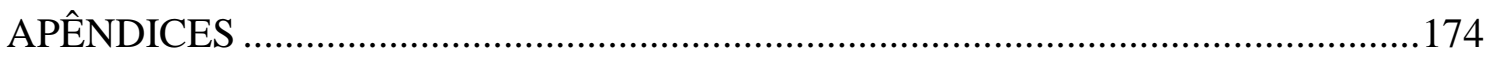

APÊNDICE A - Carta-convite para participação da pesquisa......................................174

APÊNDICE B - Roteiro para entrevista com o Quintessa..........................................175

APÊNDICE C - Roteiro para entrevista com empreendedores sociais ........................178

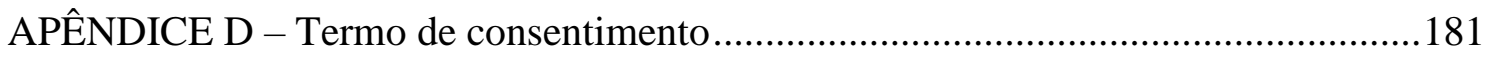

APÊNDICE E - Negócios acelerados pelo Quintessa .................................................183 


\section{INTRODUÇÃO}

Quando Muhammad Yunus - conhecido como "banqueiro dos pobres" (YUNUS, 2000) - ganhou, em 2006, o Prêmio Nobel da Paz, os negócios sociais receberam grande atenção da opinião pública, alcançando projeção e visibilidade globais até então sem precedentes. A experiência bem-sucedida e inovadora do microcrédito em Bangladesh deu força à tese do economista bengali de que o empreendedorismo é hoje a melhor solução para combater os problemas sociais que afetam o planeta.

Desde então, os negócios sociais seguem em expansão, inclusive no Brasil. Trata-se de organizações que, ou pela ausência ou em complemento às iniciativas estatais ou às organizações privadas tradicionais, se lançam na busca por soluções de problemas sociais. Não é tarefa fácil. Não é tarefa para um só. Somente pela articulação e engajamento de diferentes segmentos sociais em torno dos problemas da sociedade poderão emergir soluções efetivas para o desenvolvimento sustentável. Por isso, faz-se urgente criar novos canais de diálogo entre Estado, organizações e sociedade civil, em que os processos comunicacionais são fundamentais.

Os estudos sobre comunicação integrada e sobre negócios sociais ganharam fôlego no Brasil na mesma época, e não por mera coincidência: a redemocratização do país, no final da década de 1980, abriu espaço para pesquisas que ressaltavam o protagonismo da sociedade civil, que desempenhou papel decisivo no final da ditadura militar e na consolidação da Constituição de 1988. Naquele momento, crescia o número de pesquisas de natureza interpretativa, que enfatizavam a comunicação pelo seu potencial dialógico e transformador da realidade social.

A partir de então, a comunicação passou a ser identificada como elemento estratégico nas organizações, que passaram a atuar em um mercado cada vez mais aberto e competitivo (TORQUATO, 2009). Os profissionais de comunicação migraram, em parte, das redações para as empresas, focando o discurso, a imagem e identidades organizacionais. Paralelamente, cresceu o número de pesquisas em comunicação organizacional que pretendiam estudar "todo o sistema, o funcionamento e o processo da comunicação entre a organização e seus diversos públicos” (KUNSCH, 2016, p. 149) em busca de maior eficiência, eficácia e efetividade de suas estratégias de comunicação.

É neste cenário que observamos emergir a comunicação integrada, uma filosofia e política de comunicação organizacional pela qual as quatro dimensões da comunicação - institucional mercadológica, interna e administrativa - canalizam seus esforços de 
maneira coordenada e planejada para os objetivos institucionais e de negócios das organizações (KUNSCH, 2006), levando em conta as demandas, os interesses e as exigências dos públicos e da sociedade. Assim, a comunicação organizacional passou a ser mais valorizada tanto no mercado profissional quanto no meio acadêmico (KUNSCH, 2006), e a comunicação integrada ganhou espaço em agências e departamentos de comunicação (PALMERSTON et al., 2004) e nas universidades.

O surgimento dos estudos de comunicação organizacional à época da redemocratização do país também fez crescer o número de pesquisas em uma área que se convencionou chamar, na década de 1980, de relações públicas comunitárias (KUNSCH, 2007b), numa aproximação das relações públicas com a comunidade que estendeu a perspectiva da profissão para além dos objetivos empresariais predominantes até então. Os estudos nessa área privilegiam conceitos e fundamentos para as relações públicas em diferentes frentes de atuação, principalmente em ações com a comunidade, programas de responsabilidade social e gestão de processos comunicativos em organizações do terceiro setor.

Este estudo integra um campo de pesquisa fértil, que abrange investigações interdisciplinares nos campos da comunicação organizacional e da administração, percorrendo temáticas variadas: gestão integrada da comunicação, negócios sociais, negócios híbridos, sustentabilidade, responsabilidade social, empreendedorismo, políticas e estratégicas de comunicação e participação social.

O potencial para realizar pesquisas e gerar conhecimento sobre os negócios sociais, por sua vez, parece se evidenciar no número de teses e dissertações relacionadas à temática ${ }^{1}$. Também identificamos relatórios sobre a atuação dos negócios sociais no Brasil produzidos por organizações desse ecossistema, os quais, apesar de sua natureza qualitativa, descritiva e da baixa representatividade em todo o país, mostram tendências importantes do setor. Contudo, apesar do crescimento do número de pesquisas sobre os negócios sociais, é necessário ainda construir as bases e referências deste novo campo do conhecimento (ROSOLEN; TISCOSKI; COMINI, 2014).

\footnotetext{
${ }^{1}$ A base de dados on-line da Coordenação de Aperfeiçoamento de Pessoal de Nível Superior (CAPES) abrigava, até junho de 2019, 89 trabalhos, recuperados por meio de busca simples pelo termo negócios sociais. Desses, 57 são ligados à área da administração e nove ao direito, enquanto outras áreas do conhecimento figuram em menor número. Foi localizado um estudo na área de comunicação (MEDEIROS, 2018); no entanto, após consulta à tese, observamos que o estudo - centrado nas ações de responsabilidade social da Fundação Roberto Marinho - fugia do escopo proposto pela pesquisadora, razão pela qual foi desconsiderado.
} 
A etapa empírica desta pesquisa foi desenvolvida em uma aceleradora de negócios sociais, a Associação Quintessa² (www.quintessa.org.br). Criada há dez anos com o objetivo de estimular o empreendedorismo social e impulsionar novas formas de fazer negócios, a aceleradora atua no apoio e gestão de novos empreendimentos com o propósito de ajudar a resolver problemas sociais coletivos. Neste estudo, constituem o corpus para a nossa pesquisa empírica entrevistas com funcionários da associação e empreendedores de negócios sociais acelerados, documentação diversificada e observação direta.

O estudo de caso vincula-se a um tema central - o processo de comunicação em negócios sociais -, a partir do qual estabelecemos como objetivo geral analisar a gestão da comunicação para acelerar negócios sociais, ou seja, para amadurecer mais rapidamente um negócio cuja missão social seja central e determinante para o modelo de gestão organizacional. Entendemos que a relevância e a originalidade desta pesquisa se encontram no fato de que são identificados poucos trabalhos dedicados à comunicação dos negócios sociais - uma das razões que motivaram esta proposta investigativa.

A justificativa deste estudo reside ainda na importância de reforçar o caráter estratégico da comunicação organizacional em novos padrões, como é o caso dos negócios sociais, entre os quais é comum adotar modelos de negócios híbridos cujos formatos mesclam características de organizações com e sem fins lucrativos a fim de alcançar resultados de valor econômico e social. Justifica-se também pelo poder e pela relevância que a comunicação assume no mundo de hoje, em organizações dos três setores (KUNSCH, 2015), e pelos desafios impostos para o desenvolvimento de ações de comunicação eficazes para articular e engajar diferentes segmentos sociais em práticas efetivas e de real interesse da sociedade.

Pretende-se, assim, contribuir para os estudos da comunicação organizacional, que possui volume expressivo e qualificado de pesquisas em instituições públicas, empresas privadas e organizações do terceiro setor. Pela natureza deste estudo e pelas próprias características dos negócios sociais, pretende-se ainda contribuir com pesquisas sobre comunicação para a sustentabilidade, que já conta com contribuições importantes do campo da comunicação em ações de responsabilidade socioambiental de empresas tradicionais e organizações do terceiro setor - dois públicos dos negócios sociais.

\footnotetext{
${ }^{2}$ Para fins deste estudo, adotamos, deste ponto em diante, o nome fantasia "Quintessa" para designar a organização, comumente utilizado pela aceleradora.
} 
A sequência lógica do estudo (Figura 1) foi adequada aos objetivos e problema de pesquisa, estando a dissertação estruturada em seis partes: "Introdução", conforme já descrita; "Estratégias metodológicas"; dois capítulos de fundamentação teórica, que contemplam negócios sociais (Capítulo 3) e comunicação e negócios sociais (Capítulo 4); o estudo de caso com o Quintessa (Capítulo 5), que engloba todo o processo de coleta de dados, análise e reflexões sobre resultados da pesquisa empírica; e, por fim, as "Considerações finais", que incluem conclusões, limitações do estudo e sugestões de novas pesquisas na área.

Figura 1 - Sequência lógica do estudo

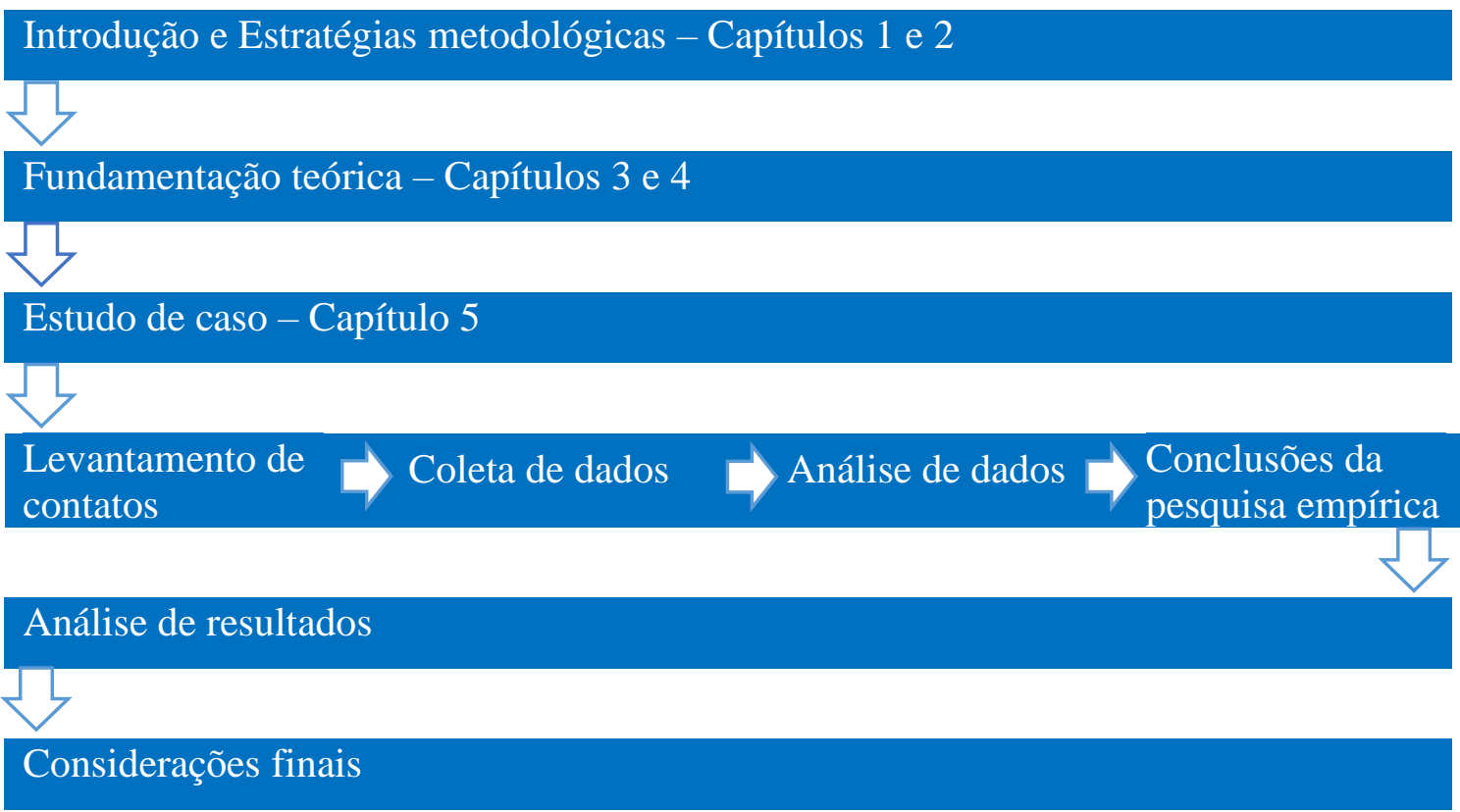

Fonte: Elaborada pela autora.

Em "Estratégias metodológicas", justificamos a escolha do método de estudo de caso e apresentamos a abordagem do autor de referência escolhido para este estudo (YIN, 2001), assim como objetivos e premissas iniciais da pesquisa. Descrevemos as técnicas adotadas para a coleta e análise dos dados, que se vale da técnica de análise de conteúdo (BARDIN, 2002).

O Capítulo 3 aborda uma revisão da literatura sobre negócios sociais, na qual a pesquisadora contextualiza o setor e apresenta os estudos identificados. Contemplam esta etapa do estudo: um breve resgate das origens dos negócios sociais, mostrando sua relação com as demandas sociais da contemporaneidade; as reflexões de autores da área quanto ao conceito e às características dos negócios sociais, com foco nos diferentes formatos 
organizacionais observados no empreendedorismo social; as possíveis contribuições dos negócios sociais para uma agenda local e global de sustentabilidade, tendo como referenciais os Objetivos de Desenvolvimento Sustentável (ODS) da Organização das Nações Unidas (ONU) (BRASIL, [201-]); e, por fim, uma revisão com dados do próprio setor acerca de desafios e oportunidades para os negócios sociais, visando articulá-la, em momento posterior, com os estudos de comunicação integrada.

No Capítulo 4 apresentamos o referencial teórico que servirá de base para as questões de pesquisa. Desenvolvemos reflexões acerca da comunicação integrada em negócios sociais numa dupla abordagem: teórico-conceitual, refletindo sobre conceitos, características e contribuições ao campo da comunicação organizacional; e práticareflexiva, tratando das políticas e filosofias da comunicação integrada. Completam esse capítulo tópicos da comunicação que contribuem de forma importante para o estudo aplicado aos negócios sociais: a conceituação de públicos, a comunicação para a sustentabilidade em empresas privadas tradicionais e organizações do terceiro setor e as relações públicas comunitárias.

O Capítulo 5 apresenta o estudo de caso propriamente dito, caracterizando a coleta de dados e o perfil da Associação Quintessa e de três negócios por ela acelerados: a escola de inglês 4YOU2 (www.4you2idiomas.com.br), o e-commerce Banca do Bem (www.lojabancadobem.com.br) e a empresa de mobilidade urbana sustentável E-Moving (www.e-moving.com.br). Discutimos também os resultados da análise das evidências coletadas.

$\mathrm{Na}$ última parte, "Considerações finnais", apresentamos as conclusões da pesquisa, assim como suas limitações. A etapa final deste estudo aponta perspectivas para investigações futuras, com proposta, ainda em construção, de uma matriz de estudos da comunicação integrada em negócios sociais híbridos, determinando fatores de classificação das dimensões da comunicação integrada e classificando-as pela sua lógica de mercado ou social, visando, com isso, refletir sobre os aspectos relevantes para uma comunicação de impacto social. 


\section{ESTRATÉGIAS METODOLÓGICAS}

Diante da temática escolhida e das motivações que impulsionam nosso estudo, optamos por apresentar, inicialmente, as estratégias metodológicas adotadas. Isso porque a escolha do método é decisiva no transcorrer de todo o trabalho, devendo considerar sua

problemática e seus objetivos sem perder de vista sua aplicabilidade e viabilidade prática.

As estratégias metodológicas utilizadas têm por finalidade conceber uma investigação exploratória e de natureza qualitativa, elegendo-se como abordagem o estudo de caso - para fins desta pesquisa, um estudo de caso único com subunidades múltiplas de análise - com aplicação das seguintes técnicas de coleta de dados: documentação, entrevistas em profundidade semiabertas e observação direta. Para avaliar os dados, optamos pela técnica de análise de conteúdo, tendo como referência os estudos de Bardin (2002). Com os resultados empíricos, propomos analisar os dados obtidos nas entrevistas no Quintessa e nos negócios sociais por ele acelerados tendo como referência a proposição teórica da comunicação integrada.

Tuzzo e Manieri (2011) afirmam que a pesquisa empírica, na comunicação, permite oferecer dados à reflexão, sendo fonte de transformação de discursos teóricos. Braga (2011, p. 6) ressalta ainda que a pesquisa empírica exige a observação direta da realidade, a partir de um recorte, e procura respostas a partir de perguntas sobre certos aspectos do objeto de estudo, de modo a "enfrentar a resistência da realidade, cercá-la com nossa problematização e ser capaz de perceber alguma coisa ali que, por mais modesta e singular, antes não era claramente percebida”. Quando aplicadas aos estudos do campo da comunicação organizacional, as pesquisas empíricas "exploram, descrevem, explicam e formulam predições sobre os acontecimentos do mundo que nos rodeia" (TUZZO; MANIERI, 2011, p. 240).

A identificação inicial de um complexo ecossistema de negócios sociais, repleto de arranjos e rearranjos, exige, a nosso ver, uma postura de análise mais global - o que motivou a escolha por uma pesquisa qualitativa. Para Roxo (2016, p. 126), esse tipo de investigação tenta "atingir seus objetivos de forma indutiva, através de um conjunto de inferências levantadas no transcurso da pesquisa”. Diferentemente da pesquisa quantitativa, o foco "não será a distribuição de opiniões conforme gêneros ou faixas etárias, mas sim os temas abordados e a estrutura argumentativa das respostas" (KISCHINHEVSKY, 2016, p. 291). 
Quanto à finalidade de pesquisa, a opção pelo estudo exploratório permitiu "localizar e identificar quais são os autores que estão trabalhando com o tema, com qual referencial teórico-metodológico e com quais palavras-chave" (BARICHELLO, 2016, p. 134). Neste sentido, o levantamento bibliográfico realizado para fins deste estudo buscou contextualizar a ação dos negócios sociais no Brasil, articulando referências teóricas quanto às suas origens e conceito, sua caracterização do ecossistema, relação com a sustentabilidade e seus desafios contemporâneos.

Em seguida foi a vez de articular as referências teóricas do campo da comunicação organizacional, em particular da comunicação integrada - teoria a partir da qual serão analisados os resultados empíricos do estudo de caso -, com estudos da comunicação para a sustentabilidade e das relações públicas comunitárias, sempre tendo em vista as características e particularidades dos negócios sociais. Complementam esta etapa da pesquisa reflexões acerca de políticas e estratégias de comunicação para negócios sociais, notadamente contribuindo para a conceituação lógica de públicos do setor.

Para Malhotra (2006), a pesquisa qualitativa exploratória sustenta-se em metodologia exploratória, não estruturada e baseada em pequenas amostras, que devem proporcionar maior compreensão e percepção do contexto estudado. Tal estratégia é indicada quando é necessário aprofundar conceitos preliminares sobre um tema que não foi analisado de forma adequada anteriormente, como se verificou no levantamento bibliográfico, que aponta a necessidade de novas referências que articulem estudos da comunicação e dos negócios sociais.

Selltiz, Wrightsman e Cook (1975) apontam que a pesquisa exploratória tem como objetivo examinar temas pouco estudados, desenvolver conceitos de forma mais clara e buscar padrões, hipóteses e ideias. Marconi e Lakatos (2003) identificam uma tripla finalidade desse tipo de pesquisa, envolvendo a possibilidade de: desenvolver hipóteses; compreender melhor conceitos; e aumentar a familiaridade do pesquisador com o objeto de estudo, tendo em vista pesquisas futuras.

\subsection{Método de pesquisa: o estudo de caso}

O método utilizado nesta pesquisa foi o estudo de caso, nos termos propostos por Yin (2001, p. 35), segundo o qual esse recurso "representa uma maneira de se investigar um tópico empírico seguindo-se um conjunto de procedimentos pré- 
especificados". Não deve ser confundido com o método do caso, amplamente difundido como estratégia de ensino do campo da administração (GODOY, 1995). O estudo de caso constitui estratégia de pesquisa abrangente, com técnicas específicas para coleta e análise de dados, dos quais serão tiradas conclusões motivadas pelas questões iniciais propostas.

Com o objetivo de "proporcionar vivência da realidade por meio da discussão, análise e tentativa de solução de um problema extraído da vida real" (GODOY, 1995, p. 25), o estudo de caso:

- enfrenta uma situação tecnicamente única em que haverá muito mais variáveis de interesse do que pontos de dados, e, como resultado,

- baseia-se em várias fontes de evidências, com os dados precisando convergir em um formato de triângulo, e, como outro resultado,

- beneficia-se do desenvolvimento prévio de proposições teóricas para conduzir a coleta e análise de dados. (YIN, 2001, p. 32-33)

Enquanto estratégia de pesquisa, o estudo de caso procura compreender os processos sociais em determinado contexto. Para isso, Freitas e Jabbour (2011) propõem um protocolo de pesquisa próprio para o método, que deve contemplar: a questão e o objetivo principal da pesquisa, embasamento teórico, a definição da unidade de análise, escolha dos potenciais entrevistados e múltiplas fontes de evidência; período de realização; local da coleta de evidências; validação do estudo por meio de múltiplas fontes de evidência; e síntese do roteiro de entrevista.

Em nosso estudo de caso o tema central é o processo de comunicação em negócios sociais e as questões iniciais propostas são:

- Quais dimensões da comunicação integrada são identificadas nos negócios sociais?

- Quais meios, técnicas e práticas de comunicação são adotados em negócios sociais e por quê?

- Quais são as diferenças identificadas na comunicação de um negócio social e de um tradicional?

- Nos negócios sociais, a comunicação se configura de forma planejada e estratégica ou ocasional e operacional? Em qual estágio do negócio?

- Como a comunicação se relaciona com as estratégias de negócio e a tomada de decisões?

- Em qual estágio do negócio a comunicação passa a ser trabalhada do ponto de vista da estratégia de negócio?

- Como são abordadas questões ligadas à sustentabilidade na comunicação dos negócios sociais? 
- Qual é a influência dos ODS na comunicação dos negócios sociais?

As questões iniciais formuladas para fins deste estudo levaram à identificação do caso. Observamos, no amplo conjunto de questões propostas, a recorrência de questões do tipo "como" ou "por que" sobre um conjunto de acontecimentos de um fenômeno da contemporaneidade - os negócios sociais. Além disso, é mínimo o controle que a investigadora deste estudo tem sobre os eventos, haja vista que tanto o comportamento dos entrevistados quanto as dinâmicas e trocas comunicativas entre Quintessa e negócios acelerados acontecem independentemente da sua vontade e controle. Assim, todas as características expostas anteriormente tornaram vantajosa a escolha do método de estudo de caso, na perspectiva de Yin (2001).

Desta forma, foi possível determinar a unidade de análise a partir das questões e do método de pesquisa, a qual pode ser "o indivíduo, uma prática cultural, um processo de trabalho, um grupo de pessoas ou mesmo a política e a estratégia organizacional" (FREITAS; JABBOUR, 2011, p. 14), a depender do objetivo pretendido com o estudo de caso. Para fins desta investigação, optou por um estudo de caso único, de natureza representativa ou típica - o Quintessa -, cuja unidade de análise compreende o objetivo geral da pesquisa. Também foram adotadas subunidades de análise, que correspondem aos objetivos específicos deste estudo, a saber:

- refletir sobre a comunicação dos negócios sociais em um contexto de desenvolvimento sustentável;

- analisar a comunicação dos negócios sociais sob uma filosofia e política de comunicação integrada;

- identificar e analisar, em nível estratégico, tático e operacional, práticas e técnicas de comunicação adotadas pelos negócios sociais.

Ressaltamos que, assim como qualquer método de pesquisa, o estudo de caso também incorrerá em limitações no que se refere à análise dos dados - os estudos de caso único são criticados, por exemplo, por fornecer pouca base para generalizações científicas. Porém, a despeito das limitações, esse "é o método mais adequado para conhecer em profundidade todas as nuances de um determinado fenômeno organizacional" (FREITAS; JABBOUR, 2011, p. 13).

Ao final, nosso objetivo, neste estudo, foi contemplar as cinco características gerais de Yin (2001) para um estudo de caso exemplar: ser significativo, tanto para os 
estudos de comunicação organizacional quanto para o ecossistema de negócios sociais; ser completo, a despeito dos prováveis limites de pesquisa; considerar perspectivas alternativas, proporcionando uma investigação crítica da temática; apresentar evidências suficientes, que sustentem ou contestem as premissas deste trabalho; e ter uma redação envolvente, que instigue a leitura e amplie a transmissão dos resultados alcançados.

\subsection{Técnicas de coleta e análise de dados}

Com vistas a ligar de forma lógica os dados da pesquisa empírica às questões iniciais e unidades de análise, escolhemos variadas técnicas de coleta de dados, consultando documentação e realizando entrevistas em profundidade semiabertas e observação direta no Quintessa.

A escolha pelo Quintessa se justifica em virtude da sua atuação no fomento de novos negócios sociais, do vínculo aos objetivos de desenvolvimento sustentável na escolha dos negócios acelerados e da sua influência e participação ativa no ecossistema estudado. Justifica-se ainda pela falta de estudos mais detalhados que avaliem a efetiva contribuição de aceleradoras na consolidação dos negócios sociais (COMINI, 2016).

Com o propósito de obter uma visão mais abrangente e polifônica do papel da comunicação no relacionamento entre aceleradora e negócios sociais, optamos também por coletar informações em negócios acelerados. Tal escolha é motivada, sobretudo, pela necessidade de, no estudo de caso,

\footnotetext{
mostrar a multiplicidade de dimensões presentes numa determinada situação, uma vez que a realidade é sempre complexa. Desta forma, para uma apreensão mais completa do fenômeno em estudo, é preciso enfatizar as várias dimensões em que ele se apresenta, assim como o contexto em que se situa. A divergência e os conflitos, tão característicos da situação social, devem estar presentes no estudo (GODOY, 1995, p. 25-26).
}

Desse modo, foram escolhidos três negócios acelerados pelo Quintessa para coleta de dados: 4YOU2, E-Moving e Banca do Bem. A pesquisadora teve acesso a dados fornecidos pela aceleradora e pelos negócios acelerados (notícias na imprensa, site, relatórios, publicações institucionais, perfis nas redes sociais). Segundo Yin (2001), são pontos fortes da documentação a sua estabilidade (pois pode ser revisada várias vezes), exatidão, ampla cobertura e discrição (não é resultado direto do estudo de caso). Por outro lado, pode ser difícil acessá-la, sendo ainda necessário considerar a seletividade tendenciosa de quem a fornece. 
Para este estudo também foram entrevistados integrantes da aceleradora e empreendedores dos negócios acelerados. A entrevista em profundidade foi escolhida a fim de extrair informações das organizações consultadas mais do que propriamente responder às perguntas de pesquisa, garantindo, ao mesmo tempo, uma visão crítica do estudo proposto.

\footnotetext{
Mais do que uma coleta de informações interativa baseada na consulta direta a informantes, a entrevista em profundidade pode ser um rico processo de aprendizagem, em que a experiência, visão de mundo e perspicácia do entrevistador afloram e colocam-se à disposição das reflexões, conhecimento e percepções do entrevistado (DUARTE, 2005, p. 81).
}

Assim, a entrevista em profundidade representa uma "técnica qualitativa que explora um assunto a partir da busca de informações, percepções e experiências de informantes para analisá-las e apresentá-las de forma estruturada" (DUARTE, 2005, p. 62). Quanto ao tipo de entrevista, optamos por questões semiestruturadas, elaboradas a partir do problema e dos objetivos da pesquisa, conforme os roteiros apresentados nos Apêndices B e C. Dessa forma, foi possível garantir maior flexibilidade e liberdade durante as entrevistas, buscando-se explorar ao máximo a temática em pauta.

Também integram esta etapa da coleta de dados levantamentos estruturados que correspondem à identificação de práticas, ações e instrumentos de comunicação adotados por aceleradoras e negócios acelerados, obtidos, sobretudo, com os profissionais de comunicação que atuam no negócio e empreendedores entrevistados. Já a observação direta do Quintessa se deu pela participação da investigadora em eventos organizados pela aceleradora, em que foi possível verificar o posicionamento e a interação de seus principais gestores com seus públicos no ecossistema de negócios sociais.

Foi a partir deste conjunto de fontes múltiplas de evidências que os dados da etapa empírica deste estudo foram selecionados, coletados, organizados, encadeados e analisados para compor e apresentar os resultados. Para os fins deste trabalho, as hipóteses deram lugar a algumas premissas iniciais que se tornaram critérios para a interpretação das descobertas, a saber:

a) No âmbito das aceleradoras de negócios sociais, a comunicação é entendida pelo seu potencial de promover maior conscientização socioambiental e mudança de comportamento dos públicos dessas organizações.

b) A comunicação, de modo amplo, seria percebida como um elemento importante para o desenvolvimento dos negócios sociais, contribuindo para o efetivo alcance de resultados sociais e financeiros. Contudo, ainda é necessário 
estabelecer políticas e estratégicas sólidas e mais bem definidas para a comunicação dos negócios sociais, alinhadas ao plano de negócios.

c) As ações de comunicação adotadas para si e recomendadas pelas aceleradoras de negócios sociais se restringem à dimensão da comunicação mercadológica, focada em produtos e serviços, deixando em segundo plano outros aspectos da comunicação integrada.

d) Por fim, busca-se identificar, no ecossistema de negócios sociais, um campo fértil para as relações públicas, que, nas últimas décadas, acumularam sólida experiência na atuação junto a movimentos sociais e institutos de responsabilidade social, com ênfase em processos participativos e democráticos, no relacionamento com os públicos e na promoção de mudanças na realidade social.

Yin (2001) sugere que a análise dos dados de um estudo de caso compreenda uma generalização analítica, e não estatística, quando se faz inferências sobre uma população a partir de uma amostragem. Na generalização analítica, “o pesquisador está tentando generalizar um conjunto particular de resultados a alguma teoria mais abrangente" (YIN, 2001, p. 58).

Dessa forma, "os estudos de caso, da mesma forma que os experimentos, são generalizáveis a proposições teóricas" (YIN, 2001, p. 29), sendo que na etapa de análise dos dados o objetivo do pesquisador é expandir e generalizar teorias que serão apropriadas pelo estudo. Assim, continua o autor, “o método de [...] 'generalização analítica' [...] se utiliza [de] uma teoria previamente desenvolvida como modelo com o qual se deve comparar os resultados empíricos do estudo de caso" (YIN, 2001, p. 54). Por outro lado, Godoy (1995, p. 25) alerta que o pesquisador, "mesmo que inicie o trabalho a partir de algum esquema teórico, deverá se manter alerta aos novos elementos ou dimensões que poderão surgir".

Para fins deste estudo, optamos pela generalização analítica dos dados à luz da teoria da comunicação integrada, desenvolvida por Kunsch (1997, 2006, 2007a, 2009, 2016), a partir da qual descrevemos, analisamos e interpretamos os resultados do estudo de caso. Criamos, para tanto, um conjunto de categorias em que são dispostas as evidências obtidas na pesquisa empírica.

Enquanto o método consiste no caminho ordenado e sistemático percorrido pela pesquisa para se chegar a um fim, a técnica estabelece o como fazer a pesquisa, ou seja, 
a forma de agir nas diferentes etapas do método escolhido. Para fins deste estudo, seguimos a técnica de análise de conteúdo, que,

atualmente, pode ser definida como um conjunto de instrumentos metodológicos, em constante aperfeiçoamento, que se presta a analisar diferentes fontes de conteúdos (verbais ou não-verbais). Quanto a interpretação, a análise de conteúdo transita entre dois polos: o rigor da objetividade e a fecundidade da subjetividade (SILVA; FOSSÁ, 2015, p. 3).

Bardin (2002), principal referência da técnica escolhida neste estudo, divide os procedimentos para análise de conteúdo em três fases: pré-análise; exploração do material; e tratamento dos resultados, inferência e interpretação (Figura 2). Na préanálise, os dados são organizados, selecionados e lidos, empregando-se leitura geral ou flutuante (ou seja, trata-se do primeiro contato com os documentos). São sistematizadas as ideias iniciais postas pelo quadro referencial teórico, formuladas as premissas e os objetivos e estabelecidos os indicadores para interpretação das informações coletadas. A seleção de materiais obedece a quatro regras: exaustividade, representatividade - quando se tem um número elevado de dados, opta-se por uma amostra -, homogeneidade (a partir dos critérios de escolha) e pertinência quanto ao objetivo do estudo.

A exploração do material consiste em recortar todo o material coletado (entrevistas, textos, anotações em diário de campo) na forma de unidades de registro, obtendo-se, portanto, recortes em nível semântico - por exemplo, os temas identificados pela pesquisadora. Em seguida, faz-se uma primeira categorização, identificando-se as primeiras palavras-chave, agrupadas em temas correlatos. As categorias iniciais dão origem, por sua vez, às categorias intermediárias e, por fim, estas são agrupadas nas categorias finais da pesquisa, que possibilitarão as inferências. A escolha pela análise categorial é justificada tendo em vista que "é a melhor alternativa quando se quer estudar valores, opiniões, atitudes e crenças, através de dados qualitativos" (SILVA; FOSSÁ, 2015, p. 8), como os expressos no material coletado neste estudo.

$\mathrm{Na}$ fase de tratamento dos resultados, inferência e interpretação, busca-se captar os conteúdos manifestos e latentes contidos em todas as evidências coletadas, e os dados são comparados pela justaposição de categorias. Este momento da análise exige um olhar atento às referências teóricas da pesquisa, uma vez que a relação entre os dados coletados e a fundamentação teórica é o que dará sentido à interpretação.

Os procedimentos da análise de conteúdo compreendem uma descrição do teor das mensagens, a partir da qual se obtêm “indicadores (quantitativos ou não) que permitam a inferência de conhecimentos relativos às condições de produção/recepção 
(variáveis inferidas) destas mensagens" (BARDIN, 2002, p. 42). Nesse sentido, propomos inferir sobre o processo de comunicação em negócios sociais a partir da descrição e análise do conteúdo extraído dos dados coletados no Quintessa e nos negócios por ele acelerados.

O roteiro apresentado na Figura 2, criado por Bardin (2002), resume os procedimentos para a análise de conteúdo adotados neste estudo.

Figura 2 - Procedimentos para a análise de conteúdo

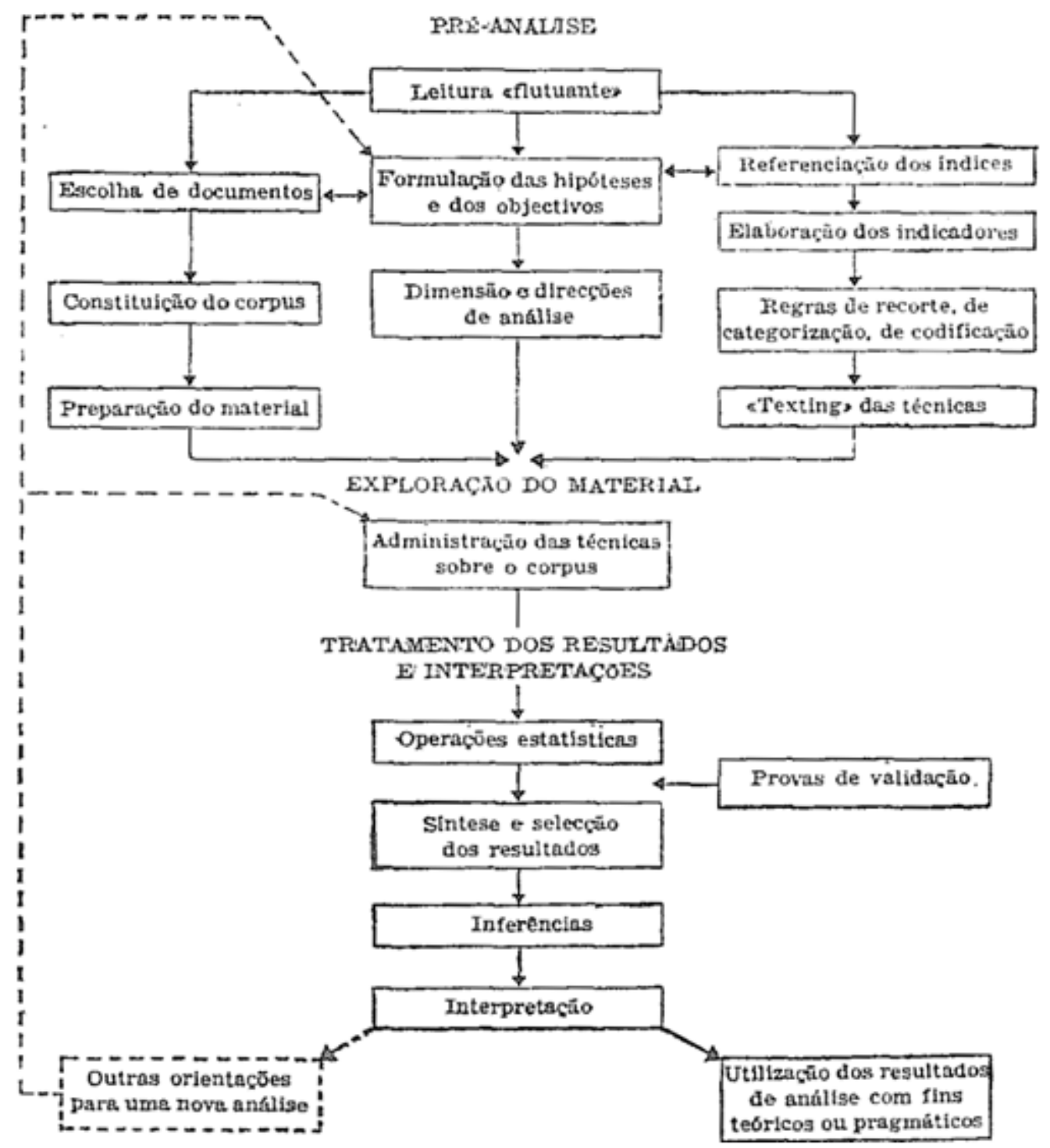

Fonte: Bardin (2002, p. 102).

A escolha da análise de conteúdo para este estudo justifica-se pela adequação aos objetivos e questões de pesquisa e pela ampla adesão dos estudos de ciências humanas e ciências sociais aplicadas (SILVA; FOSSÁ, 2015) para a análise de comunicações 
diversas, como documentos, entrevistas e discursos. Além disso, a categorização das unidades de registro facilita o acesso ao conteúdo, uma vez que permite padronizar critérios para a seleção e análise de dados e auxilia na comparação entre os diferentes casos, podendo ser utilizada inclusive em pesquisas mais complexas.

Quanto às limitações, ressaltamos que a categorização pode impedir uma leitura mais profunda dos dados, além de privilegiar as formas de comunicação oral e escrita, como indicam Mozzato e Grzybovski (2011). Os autores também apontam possíveis dificuldades de análises contextuais e efeitos sobre a neutralidade do pesquisador, que deve buscar critérios de validade e confiabilidade, detalhando todos os procedimentos adotados para a análise de dados (MOZZATO; GRZYBOVSKI, 2011).

A aplicação das estratégias metodológicas descritas neste capítulo será apresentada no Capítulo 5, no qual, com base nos dados coletados, expomos a análise dos resultados alcançados em três etapas: pesquisa documental, com o perfil institucional da organização escolhida para o estudo de caso; entrevistas em profundidade com membros do Quintessa, a fim de compreender a comunicação no âmbito da aceleradora; e entrevistas em profundidade com negócios sociais, em que, por meio de trechos dos depoimentos cedidos à pesquisadora, buscamos captar as percepções repassadas pelos profissionais sobre o processo de comunicação em negócios sociais. 


\section{DA SUSTENTABILIDADE CORPORATIVA AOS NEGÓCIOS SOCIAIS}

Neste capítulo, apresentamos os debates acerca do conceito de negócios sociais, realizamos um breve resgate histórico e caracterização da matéria no Brasil e discorremos sobre sua ação na contemporaneidade, sempre em interlocução com o tema da sustentabilidade e do desenvolvimento social. É dada especial atenção para a caracterização do ecossistema dos negócios sociais e a contribuição das aceleradoras. Também apresentamos um panorama das pesquisas relativas aos negócios sociais desenvolvidas nos últimos anos.

Para o desenvolvimento deste capítulo, foram essenciais as contribuições de Fischer e Comini (2012), Comini, Barki e Aguiar (2012), Comini (2011, 2016), Fischer (2012,), Dees (1998), Prahalad e Hart (2002), Yunus (2007), Alter (2007), Battilana e Lee (2014), Reficco e Vernis (2010), Porter e Kramer (2011), Portocarrero e Delgado (2010), Oliveira Filho, Kiyama e Comini (2013) e Rodrigues (2016), além de relatórios e estudos conduzidos no ecossistema de negócios sociais.

\subsection{Sobre as origens dos negócios sociais}

O termo "empresa social” começou a ser usado nos Estados Unidos no final dos anos 1970 para se referir a organizações não governamentais que passaram a expandir suas atividades comerciais motivadas pela redução de recursos de origem estatal (KERLIN, 2006). No Brasil, os negócios sociais têm sua origem ligada à redemocratização do país, na década de 1980, quando se observou o aumento da participação da sociedade civil em iniciativas de modernização do Estado, principalmente em programas e políticas sociais (FISCHER; COMINI, 2012), e estende-se até a década de 1990, com o crescimento de ações filantrópicas de empresas privadas e o protagonismo de organizações do terceiro setor (COMINI, 2016).

Para Comini (2016), o surgimento dos negócios sociais está atrelado a um longo processo que envolveu a mudança da própria definição de desenvolvimento e seus desdobramentos. Isso porque, durante as décadas de 1960 e 1970, predominou no Brasil uma visão de desenvolvimento que privilegiava o crescimento da produção industrial, numa ação combinada entre Estado e setor privado (FISCHER; COMINI, 2012). "Desenvolvimento era sinônimo de crescimento industrial e urbano, centrado em objetivos macroeconômicos e frequentemente separados das necessidades 
socioambientais específicas de cada lugar e sua população"33 (FISCHER; COMINI, 2012, p. 364, tradução nossa).

Nos anos 1980, contudo, a recessão econômica mundial acentuou a inadequação do processo de crescimento econômico brasileiro. Naquele momento, o conceito de desenvolvimento começava a ganhar um sentido mais amplo, levando em consideração a noção de sustentabilidade (FISCHER; COMINI, 2012), que pressupõe padrões de desenvolvimento baseados nas especificidades de cada localidade. Fortemente ligado às causas ambientais, o conceito de sustentabilidade "esboçou-se em seguida como um construto de maior complexidade porque passou a abranger, concomitantemente, ampla gama de componentes da vida social e de agentes sociais" (FISCHER, 2001, p. 28).

Dessa maneira, o conceito de crescimento, popular nas décadas de 1960 e 1970 e ligado, sobretudo, a indicadores econômicos, mostrava-se insuficiente para atender às demandas sociais crescentes da redemocratização brasileira das décadas de 1980 e 1990, dando lugar a uma outra noção de desenvolvimento:

Tão importante quanto os bens materiais é saber a que finalidades servem e, sobretudo, é avaliar o acesso dos indivíduos a bens públicos e serviços coletivos que definem seu lugar social e ampliam (ou limitam) suas chances de cooperação social. Liberdade política, uso real (e não só direito legal) da palavra, ausência de discriminação de gênero e de raça, por exemplo, são constitutivos do desenvolvimento, tanto quanto as condições materiais que dão base a essas liberdades (ABRAMOVAY, 2015, n. p.).

Sen (2010) também apresenta uma visão mais abrangente do conceito de desenvolvimento, entendido como o processo de expansão das liberdades substantivas dos seres humanos e de suas capacidades para fazer escolhas. Propõe, para tanto, uma análise integrada de desenvolvimento que contemple dimensões econômicas, sociais e políticas e seus diversos atores, em que são necessárias certas "liberdades instrumentais" (SEN, 2010, p. 58): liberdades políticas, facilidades econômicas, oportunidades sociais, garantias de transparência e segurança protetora. É neste contexto que irão surgir os negócios sociais, quando se observa maior incentivo a iniciativas que contemplem a noção de desenvolvimento em suas múltiplas dimensões.

$\mathrm{Na}$ prática, esse entrelace entre responsabilidade social e o mundo corporativo ganhou impulso no Brasil, "por meio da ação de entidades não-governamentais, institutos de pesquisa e empresas sensibilizadas pela questão" (GONÇALVES et al., 2007, p. 138), somente após a ECO-92, Conferência das Nações Unidas sobre o Meio Ambiente e o

\footnotetext{
3 No original: "Development was synonymous with urban and industrial growth, centered on macroeconomic targets and often divorced from the specific environmental and social needs of each place and of its population".
} 
Desenvolvimento, realizada no Rio de Janeiro em 1992. São dessa época as primeiras associações empresariais de desenvolvimento sustentável e responsabilidade social: em 1995 foi criado o Grupo de Institutos, Fundações e Empresas (GIFE); em 1997, o Conselho Empresarial Brasileiro para o Desenvolvimento Sustentável (CEBDS); e, no ano seguinte, o Instituto Ethos.

Outra ação articuladora ainda mais ampla foi capitaneada pela própria ONU, com a fundação, em 2003, da Rede Brasil do Pacto Global. A iniciativa brasileira representa hoje a quarta maior rede local da instituição, com mais de 800 signatários, sob a gestão do Comitê Brasileiro do Pacto Global, formado por representantes da ONU, de entidades empresariais, organizações da sociedade civil, instituições de ensino, entre outros. Essas iniciativas foram criadas com o objetivo de promover ações que auxiliem as empresas a compreender e incorporar os conceitos de responsabilidade social e sustentabilidade no cotidiano de suas gestões. Com efeito, as organizações "passaram a assumir mais poderes e, ao mesmo tempo, são chamadas a exercer novos papéis, sobretudo em relação à responsabilidade social e à sustentabilidade" (KUNSCH, 2009, p. 63).

Assim, os primeiros anos de redemocratização do Brasil revelaram a necessidade de "construir um Estado sensível às necessidades sociais, capaz de criar políticas que respeitassem a diversidade e que fornecessem os meios de comunicação aos diversos atores sociais, permitindo sua participação"4 (FISCHER; COMINI, 2012, p. 366, tradução nossa), fomentando assim parcerias entre diferentes setores da sociedade. Por outro lado, já nessa época começam a ser observadas deficiências nos mecanismos de participação da sociedade civil em programas sociais e iniciativas governamentais para a população de baixa renda.

Neste contexto, observa-se também o surgimento de um novo formato organizacional, que opera em função dois objetivos centrais, até então entendidos como incompatíveis: geração de valor social e sustentabilidade financeira (COMINI, 2011). Os negócios sociais iriam além de ações de responsabilidade social e boas práticas corporativas que naquele momento vinham ganhando espaço nas grandes empresas brasileiras e multinacionais: a intencionalidade do negócio, ou seja, a sua razão de ser, é fundamentalmente social e tão importante quanto os resultados financeiros alcançados pelo empreendimento (FISCHER; COMINI, 2012).

\footnotetext{
${ }^{4}$ No original: "to build a State sensitive to social needs, capable of creating policies that respected diversity and that provided the means of communication to the several social players, allowing their participation".
} 
Os negócios sociais estão presentes em segmentos bastante diversificados, tais como educação, saúde, moradia, combate à fome e preservação ambiental, em que não há atuação forte do mercado e em complemento às iniciativas governamentais (DEES, 1998). Quanto à sua estrutura e área de atuação, os negócios sociais possuem organização formal e legal, ao contrário de uma parcela dos movimentos organizados da sociedade civil, que atua de forma mais informal e orgânica. Em diversos países da Europa, como na Bélgica, Itália e no Reino Unido, existe uma regulamentação específica para novos formatos de organizações com finalidades sociais (KERLIN, 2006).

Dados recentes mostram a ascensão do segmento no Brasil e no exterior: os negócios sociais têm movimentado cerca de US\$ 60 bilhões em nível global, registrando um crescimento aproximado de 7\% ao ano, segundo estudo da Aspen Network of Development Entrepreneurs (ANDE Brasil) et al. (2014). Na América Latina, foram investidos cerca de US\$ 1,4 bilhão em negócios sociais, sendo Peru, Equador e México os países que receberam maior volume de capital em 2016 e 2017, levantamento no qual o Brasil aparece somente em quarto lugar (DAVIDSON; ROCHA, 2018). Estudo do Serviço Brasileiro de Apoio às Micro e Pequenas Empresas (SEBRAE) em parceria com o Programa das Nações Unidas para o Desenvolvimento (PNUD) identificou mais de 800 negócios sociais em todo o Brasil, em sua maioria startups voltadas ao atendimento de demandas da população de baixa renda (BRITO, 2018).

Apesar de a linguagem sobre o tema parecer nova, o fenômeno em si já era conhecido (DEES, 1998). A nova nomenclatura, porém, teria função de diluir fronteiras entre setores e atores sociais.

\subsection{Negócios sociais: um conceito em construção}

Campo de estudos recente e pouco explorado pelos pesquisadores, os negócios sociais ainda carecem de consenso quanto ao uso de uma terminologia única. Para fins deste estudo, esclarecemos inicialmente dois conceitos: empreendedorismo social e negócios sociais, expressões por vezes usadas como sinônimos.

Empreendedores costumam ser identificados como agentes do progresso econômico - ligados a processos de inovação - capazes de mobilizar recursos de setores pouco produtivos para áreas de maior retorno e produtividade (FISCHER; COMINI, 2012). Os empreendedores podem ter suas habilidades canalizadas para diferentes tipos de organizações e, enquanto agentes de mudanças sociais, atuam "reconhecendo e 
perseguindo implacavelmente novas oportunidades para servir a sua missão, engajandose em um processo contínuo de inovação, adaptação e aprendizado" (DEES, 1998, n. p., tradução nossa). Segundo Dees (1998, n. p., tradução nossa), os empreendedores sociais nada mais são do que empreendedores cujos negócios têm uma missão social, a qual "é central e explícita"6, e a sustentabilidade financeira do negócio é apenas um meio para se alcançar uma finalidade.

Assim, o "empreendedorismo social" (no inglês, social entrepreneurship) refere-se, em linhas gerais, a uma atividade inovadora com objetivo social, podendo ocorrer no setor privado, no terceiro setor ou em organizações híbridas (AUSTIN; STEVENSON; WEI-SKILLERN, 2012). A expressão “negócios sociais”, por sua vez, designa iniciativas organizacionais, agrupadas em diferentes setores de mercado, que visam "prover soluções eficientes para os problemas sociais e com sustentabilidade financeira por meio de mecanismos de mercado"7 (FISCHER; COMINI, 2012, p. 367, tradução nossa).

"Empresas sociais" (social enterprise) e "negócios inclusivos" (inclusive business) são outros termos conhecidos nesta área. Na Ásia e na maioria dos países da América Latina há certa resistência quanto ao termo "empresa social", optando-se pela expressão "negócios inclusivos"; já no Brasil predomina o termo "negócios sociais" (COMINI, 2011), razão pela qual adotamos esta expressão neste estudo. O que todas essas terminologias têm em comum é a "noção de usar um modelo de negócios com um propósito maior, financeiramente sustentável e que tenha impacto social"8 (YOUNG, 2007 apud BARKI et al., 2015, p. 380, tradução nossa). Comini, Barki e Aguiar (2013) alertam para o fato de que a pluralidade de conceitos e terminologias pode representar uma barreira para o desenvolvimento desses negócios.

Nos Estados Unidos, o termo "empresa social" é usado de maneira ampla para se referir a diferentes atividades que visam alcançar certo benefício social. Pode se referir a entidades híbridas com finalidades sociais e metas financeiras, a organizações sem fins lucrativos que desenvolvem atividades comerciais e a empresas dedicadas à oferta de

\footnotetext{
${ }^{5}$ No original: "Recognizing and relentlessly pursuing new opportunities to serve that mission, Engaging in a process of continuous innovation, adaptation, and learning".

${ }^{6}$ No original: "explicit and central".

${ }^{7}$ No original: "to solve social problems efficiently and with financial sustainability through market mechanisms".

${ }^{8}$ No original: "the notion of using a business model with a higher purpose, financially sustainable and that has a social impact".
} 
produtos e serviços para parcelas da população que são excluídas do consumo (ROSOLEN; TISCOSKI; COMINI, 2014).

Nos Estados Unidos também é usual ver o termo "negócio social" associado a estratégias ou simplesmente negócios da base da pirâmide (COMINI, 2011). Trata-se de modelos de negócios voltados à população de baixa renda que fornecem recursos para produção e administração de produtos locais e que sejam, ao mesmo tempo, economicamente rentáveis e responsáveis com o meio ambiente (PRAHALAD; HART, 2002).

$\mathrm{Na}$ Ásia, a grande referência sobre o tema é o bengali Muhammad Yunus. O criador do Grameen Bank entende que os negócios sociais devem ter como objetivo principal o impacto social e que todo o lucro obtido pela empresa deve ser reinvestido no próprio negócio. "Yunus é estudado em várias partes do mundo e seu modelo é amplamente reconhecido, especialmente em países como Bangladesh e Índia” (COMINI; BARKI; AGUIAR, 2013, p. 54).

Yunus (2007) identifica dois tipos de negócio social: aquele que busca oferecer um benefício social - redução da pobreza, justiça social, sustentabilidade - ao invés de maximizar lucros para seus donos e acionistas; e aquele que é de propriedade dos mais pobres, cujo lucro é distribuído por dividendos ou direcionado a um projeto de interesse de um público específico. O autor define sete princípios para iniciar um negócio social:

\footnotetext{
O objetivo da empresa será superar a pobreza, ou um ou mais problemas (como educação, saúde, acesso à tecnologia e meio ambiente) que ameacem as pessoas e a sociedade; não maximizar o lucro.

Sustentabilidade financeira e econômica

Os investidores recebem de volta apenas o valor do investimento. Nenhum dividendo é dado além do dinheiro investido

Quando o valor do investimento é pago de volta, o lucro da empresa permanece na empresa para expansão e melhoria

Sensibilidade de gênero e consciência ambiental

Força de trabalho recebe salário de mercado com melhores condições de trabalho

... faça isso com alegria9 (YUNUS, c2011, n. p., tradução nossa).
}

\footnotetext{
${ }^{9}$ No original: "Business objective will be to overcome poverty, or one or more problems (such as education, health, technology access, and environment) which threaten people and society; not profit maximization. Financial and economic sustainability Investors get back their investment amount only. No dividend is given beyond investment money When investment amount is paid back, company profit stays with the company for expansion and improvement

Gender sensitive and environmentally conscious

Workforce gets market wage with better working conditions

... do it with joy".
} 
Já a literatura sobre o assunto produzida na América Latina enfatiza a solução de problemas sociais, ou seja, a ação dos negócios sociais como forma de servir à sociedade e melhorar as condições de vida de populações de baixa renda. Há uma "forte preocupação na redução da pobreza e que sejam iniciativas que necessariamente tenham impacto social positivo, efetivo e, sobretudo, de longo prazo" (COMINI, 2011, p. 12).

No Brasil, os negócios inclusivos são tratados como uma subcategoria dos negócios sociais (COMINI, 2011) e não se restringem às pessoas com deficiência, como é comum nos negócios tradicionais. Os negócios inclusivos são voltados à geração de emprego e renda para pessoas em situação de vulnerabilidade social e com baixa mobilidade no mercado de trabalho, possibilitando a elas oportunidades de " "trabalho decente' e de forma autossustentável" (COMINI, 2011, p. 13). Nos negócios inclusivos, essas pessoas assumem papel preponderante na governança corporativa e, mesmo que não sejam proprietárias do negócio, participam das tomadas de decisão.

Outra terminologia comum nesta área é a expressão "negócios de impacto", que, assim como os negócios sociais, são empreendimentos que atuam com regras de mercado e que visam gerar valor econômico e social. Para Comini, Barki e Aguiar (2013), porém, o conceito de negócios de impacto é mais abrangente e atribuído a empresas ou a unidades de negócios de uma empresa tradicional com objetivos sociais. Dessa maneira, o termo "negócios de impacto" "pode ser usado também por grandes corporações que almejam desenvolver negócios que tenham lucro e impacto social ao mesmo tempo" (COMINI; BARKI; AGUIAR, 2013, p. 49, grifo dos autores).

Ainda segundo esses autores, a expressão "negócios de impacto" também foi apropriada por organizações sem fins lucrativos que passaram a atuar no mercado ofertando produtos e serviços. Variações comuns no ecossistema brasileiro e latinoamericano dos negócios sociais são as expressões "negócios socioambientais" ou "de impacto socioambiental", reforçando a importância de empreendimentos cujo propósito seja a resolução de problemas que afetam o meio ambiente.

Situam-se ainda, neste contexto, as empresas B, organizações com fins lucrativos que buscam também gerar impactos socioambientais positivos. São empresas certificadas pelo B-Lab, entidade que avalia práticas e modelos corporativos em questões como governança e relação com trabalhadores, comunidade, meio ambiente e clientes. $\mathrm{O}$ objetivo é estabelecer padrões comuns e distinguir empresas comprometidas com a responsabilidade socioambiental (RODRIGUES, 2016). Entre as vantagens de um negócio adotar a certificação B estão ganhar visibilidade de mercado, atrair consumidores 
e investidores com este propósito e participar da rede de negócios do Movimento B (RODRIGUES, 2016).

Atualmente, 104 empresas brasileiras possuem a certificação $\mathrm{B}^{10}$, com predominância nos segmentos de Agência, Consultoria e Assessoria (32), Produtos Sustentáveis (26) e Educação (16). Alguns dos negócios certificados já foram acelerados pelo Quintessa, como a 4YOU2 (educação), CAUSE (agência), Editora MOL (comunicação e marketing), Boomera (agência/produtos sustentáveis), Courri (produtos sustentáveis) e Move (educação).

O Quintessa, que será objeto do nosso estudo de caso no Capítulo 5, se denomina, de acordo com seu representante entrevistado neste estudo, uma "aceleradora de negócios de impacto" e adota a proposição da Carta de princípios para negócios de impacto no Brasil, estabelecida pela Força Tarefa de Finanças Sociais (2015a). Segundo o documento, negócios de impacto" "são empreendimentos que têm a missão explícita de gerar impacto socioambiental ao mesmo tempo em que produzem resultado financeiro positivo de forma sustentável" (FORÇA TAREFA DE FINANÇAS SOCIAIS, 2015a, p. 5).

\subsection{Mudando a forma de fazer negócios: os negócios híbridos}

As mudanças no entendimento do conceito de desenvolvimento - aproximandoo das demandas sociais coletivas - e as diversas nomenclaturas e definições para os negócios sociais revelam o quanto as iniciativas empreendedoras no campo social e ambiental podem ser diferentes entre si. Mas, afinal, no que um negócio social difere de um negócio tradicional? Alguns autores têm se dedicado a compreender como esta dimensão social tem impactado os modelos e formatos organizacionais vigentes.

Em termos de modelos de gestão, o triple bottom line, ou "tripé da sustentabilidade", é hoje a principal orientação conceitual adotada pelas grandes empresas brasileiras que empregam ações de responsabilidade socioambiental (KUNSCH; MOYA, 2014). O conceito de tripé, proposto por John Elkington em 1997, visa representar a necessidade de equilíbrio econômico, social e ambiental para viabilizar

\footnotetext{
${ }^{10}$ Dados extraídos do Sistema B (https://sistemab.org) pela pesquisadora em junho de 2019.

${ }^{11}$ O termo "negócios de impacto" é uma simplificação adotada pelo documento para a expressão "negócios de impacto social e/ou ambiental” (FORÇA TAREFA DE FINANÇAS SOCIAIS, 2015a, p. 4).
} 
o desenvolvimento sustentável, e ficou conhecido como modelo 3P (do inglês, people, planet e profit):

o desenvolvimento sustentável envolve a busca simultânea da prosperidade econômica, da qualidade ambiental e da igualdade social. As empresas que buscam a sustentabilidade precisam empenhar-se não somente na direção de uma única linha de resultados, a financeira, mas sim na linha dos três pilares (ELKINGTON, 2011, p. 429).

Segundo Elkington (2011), os três pilares andam juntos e dependem um do outro: as pessoas dependem da economia e a economia depende dos recursos ambientais, que devem ser preservados para que os três pilares continuem em pé. A intenção do autor é mostrar que o lucro, as pessoas e o meio ambiente estão interligados e, sob essa percepção, o sistema precisaria ser revisto, readaptado e equilibrado para não perecer. Observa-se, contudo, certa fragmentação do modelo de Elkington no interior das organizações: a dimensão social é desenvolvida por institutos empresariais de responsabilidade social, a dimensão ambiental está ligada às práticas produtivas nas indústrias e a dimensão econômica é tradicionalmente vinculada aos acionistas e às lideranças corporativas.

Para Kunsch (2015), a opção pelo pensamento de Elkington e seus pilares se deve ao fato de que o autor foi um dos pioneiros do trabalho com o conceito de sustentabilidade direcionado às organizações. Críticos ao modelo, contudo, ressaltam a maior ênfase dada à dimensão econômica do tripé - predominante nas grandes corporações. A visão das empresas para o desenvolvimento sustentável seria muito restrita a "um qualificativo de um processo de produção ou de um produto" (BOFF, 2012, p. 36).

Por isso, na gestão de um negócio social "é impossível reproduzir o modelo dos negócios tradicionais e simplesmente adicionar-lhe uma dimensão de ação social. [...] É necessário pensar e agir de forma diferente"12 (FISCHER; COMINI, 2012, p. 367, tradução nossa). Dees (1998, n. p., tradução nossa), por sua vez, irá defender que os empreendedores sociais são necessários para desenvolver os modelos de negócio do próximo século, uma vez que, para o autor, esses agentes "procuram pelos métodos mais eficientes para as suas missões sociais"13.

Nesse sentido, Porter e Kramer (2011) defendem a ampliação das conexões entre o progresso social e o econômico. Para que isso aconteça, objetivos empresariais precisam

\footnotetext{
${ }^{12}$ No original: "It is impossible to reproduce the traditional business model of capitalist market relations and simply add to it a dimension of social action [...]. It is necessary to think and to act differently".

${ }^{13}$ No original: "social entrepreneurs look for the most effective methods of serving their social missions".
} 
evoluir e gerar o que os autores chamam de "valor compartilhado", "que implica criar valor econômico de forma a também criar valor para a sociedade ao se direcionar às suas necessidades e desafios ${ }^{14 \text { " }}$ (PORTER; KRAMER, 2011, p. 1, tradução nossa). Para os autores,

valor compartilhado não é responsabilidade social, filantropia nem mesmo
sustentabilidade, mas uma nova forma de se obter sucesso econômico. Não
está na margem do que as empresas fazem, mas no centro. Nós acreditamos
que isso pode dar pode dar origem à próxima grande transformação do
pensamento empresarial ${ }^{15}$ (PORTER; KRAMER, 2011, p. 1, tradução nossa).

Assim, é em um contexto de "evolução do tema de responsabilidade social e sustentabilidade na busca pela inserção do valor social e ambiental na estratégia das organizações” (RODRIGUES, 2016, p. 20) que surge o conceito de negócios híbridos, que misturam elementos de negócios tradicionais e de organizações sem fins lucrativos. Para Rodrigues (2016), diferentemente de organizações com práticas de responsabilidade social e sustentabilidade, as organizações híbridas colocam lucro e geração de valor socioambiental num mesmo patamar.

Austin, Stevenson e Wei-Skillern (2012, p. 372) acreditam que as diferenças entre negócios comerciais tradicionais e aqueles sociais não são de natureza dicotômica, mas propõem "uma escala contínua que vai do puramente social ao puramente econômico[, sendo que,] mesmo nos extremos, [...] há elementos comuns a ambos" ${ }^{\text {"16. Os }}$ autores propõem quatro dimensões de análise para distinguir empreendedorismo comercial e social: falha de mercado, ou seja, quando uma parcela da população não é atendida por produtos ou serviços de sua necessidade; missão; mobilização de recursos, neste caso, dos lucros; e mensuração de performance, haja vista que negócios sociais devem apresentar, além de indicadores econômicos, resultados sociais em relação à sua atuação no mercado (AUSTIN; STEVENSON; WEI-SKILLERN, 2012).

Perspectiva semelhante é observada em Comini (2016), que apresenta um conjunto de fatores de análise com o objetivo de classificar as várias dimensões dos negócios sociais e sua ênfase no mercado ou no social (Quadro 1). São eles: objetivo

\footnotetext{
${ }^{14}$ No original: "which involves creating economic value in a way that also creates value for society by addressing its needs and challenges".

${ }^{15}$ No original: "Shared value is not social responsibility, philanthropy, or even sustainability, but a new way to achieve economic success. It is not on the margin of what companies do but at the center. We believe that it can give rise to the next major transformation of business thinking".

${ }^{16}$ No original: "a continuum ranging from purely social to purely economic. Even at the extremes, however, there are still elements of both".
} 
principal, oferta, intencionalidade, clientes, trabalhadores, envolvimento da comunidade no processo decisório, distribuição do lucro e valor econômico.

Quadro 1 - Fatores para a classificação de empreendimentos sociais

\begin{tabular}{|c|c|c|c|}
\hline & Fatores & Lógica de Mercado & Lógica Social \\
\hline \multirow{4}{*}{ 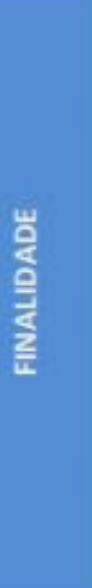 } & Objetivo principal & $\begin{array}{l}\text { Aproveitar uma oportunidade de } \\
\text { mercado Score }(-1)\end{array}$ & $\begin{array}{l}\text { Resolver um problema } \\
\text { socioambiental. Score (1) }\end{array}$ \\
\hline & Oferta & $\begin{array}{l}\text { Bens e serviços voltados para o } \\
\text { consumo da população Score (-1) }\end{array}$ & $\begin{array}{l}\text { Bens e serviços voltados para } \\
\text { necessidades básicas da população } \\
\text { ou que conservem a biodiversidade. } \\
\text { Score (1) }\end{array}$ \\
\hline & Intencionalidade & $\begin{array}{l}\text { Geração de valor social é um } \\
\text { componente importante, porém } \\
\text { não central. Score (-1) }\end{array}$ & $\begin{array}{l}\text { Geração de valor socioambiental é o } \\
\text { core business do negócio. Score (1) }\end{array}$ \\
\hline & Escala & Fator relevante Score $(-1)$ & $\begin{array}{l}\text { Replicabilidade é mais relevante que } \\
\text { a escalabilidade. Score (1) }\end{array}$ \\
\hline \multirow{3}{*}{ 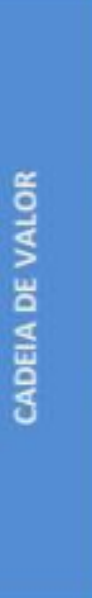 } & Clientes & $\begin{array}{l}\text { Os clientes pertencem a diversas } \\
\text { classes sociais Score }(-1)\end{array}$ & $\begin{array}{l}\text { Predominantemente segmentos da } \\
\text { população que estão em situação de } \\
\text { maior vulnerabilidade social. Score } \\
\text { (1) }\end{array}$ \\
\hline & Fornecedores & $\begin{array}{l}\text { Os critérios para escolha são } \\
\text { preço e qualidade Score (-1) }\end{array}$ & $\begin{array}{l}\text { Procura-se contratar segmentos da } \\
\text { população que estão em situação de } \\
\text { maior vulnerabilidade social. Score } \\
\text { (1) }\end{array}$ \\
\hline & Colaboradores & $\begin{array}{l}\text { Não há nenhuma prioridade na } \\
\text { contratação. Score }(-1)\end{array}$ & $\begin{array}{l}\text { Prioridade para segmentos da } \\
\text { população que estão em situação de } \\
\text { maior vulnerabilidade social. Score } \\
\text { (1) }\end{array}$ \\
\hline$\frac{\delta}{\frac{\delta}{c}}$ & $\begin{array}{l}\text { Processo } \\
\text { decisório }\end{array}$ & $\begin{array}{l}\text { Não há mecanismos institucionais } \\
\text { para participação coletiva. Score } \\
(-1)\end{array}$ & $\begin{array}{l}\text { Há mecanismos institucionais para } \\
\text { participação coletiva das } \\
\text { comunidades com as quais o } \\
\text { empreendimento atua. Score (1) }\end{array}$ \\
\hline \multirow{3}{*}{ 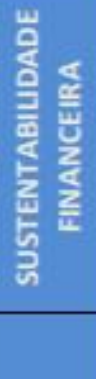 } & $\begin{array}{l}\text { Distribuiçảo de } \\
\text { lucro }\end{array}$ & $\begin{array}{l}\text { Distribuição de dividendos. Score } \\
(-1) \text { Score }(-1)\end{array}$ & $\begin{array}{l}\text { Lucro é totaimente investido no } \\
\text { empreendimento. Score (1) }\end{array}$ \\
\hline & Valor econômico & $\begin{array}{l}\text { Todos os recursos são } \\
\text { provenientes de vendas de } \\
\text { produtos e serviços. Score }(-1)\end{array}$ & $\begin{array}{l}\text { Depende de doaçōes e/ou } \\
\text { contribuições institucionais para } \\
\text { desenvolver sua atividade principal. } \\
\text { Score (1) }\end{array}$ \\
\hline & Total & -10 & 10 \\
\hline
\end{tabular}

Fonte: Comini (2016). 
A partir das notas obtidas, a autora classifica os negócios sociais em uma régua, a fim de identificar a sua lógica de atuação:

Figura 3 - Classificação dos negócios sociais, conforme lógica de atuação

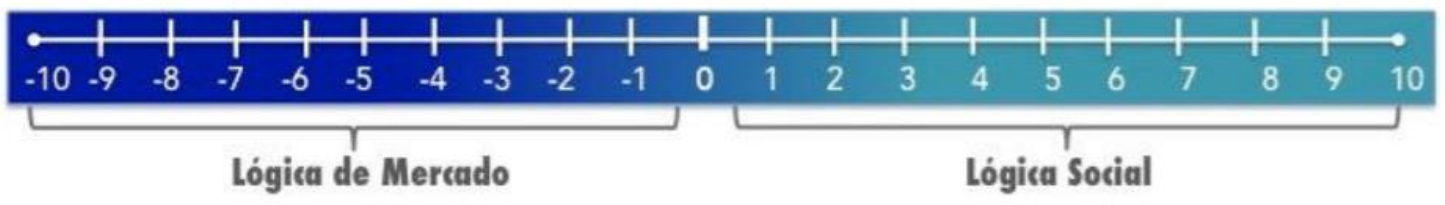

Fonte: Comini (2016).

Em sua análise, a autora ressalta ainda que o formato dos negócios sociais pode sofrer grandes variações, podendo haver negócios mais ligados aos aspectos sociais, em que se encontram as organizações sem fins lucrativos, e aqueles vinculados aos aspectos econômicos, representadas por iniciativas de mercado para a base da pirâmide de uma multinacional (COMINI, 2016).

As iniciativas de mercado voltadas para segmentos da base da pirâmide se referem à proposição, desenvolvida no final da década de 1990 por Stuart L. Hart e C. K. Prahalad, de que as organizações deveriam desenvolver produtos e serviços direcionados para essas camadas da população, reduzindo a penalização dos mais pobres (poverty penalty ${ }^{17}$ ) que, devido à sua condição de pobreza e vulnerabilidade social, sofrem com um custo de vida proporcionalmente mais alto do que o de outras camadas sociais. Para Prahalad e Hart (2002), a pobreza pode diminuir na medida em que as pessoas mais pobres sejam empoderadas enquanto consumidoras, a partir da oferta de produtos e serviços direcionados a elas.

Já Alter (2007) propõe uma escala dos negócios híbridos (Figura 4) na qual, em uma ponta, figuram os organizações sem fins lucrativos tradicionais, seguidos por organizações sem fins lucrativos com geração de renda, empreendimentos sociais, negócios socialmente responsáveis, organizações com práticas de responsabilidade social, e, na outra ponta, negócios tradicionais e lucrativos.

Um dos pontos críticos na gestão de um negócio híbrido é administrar as tensões internas e externas que resultam da combinação de formas organizacionais sociais e comerciais (BATTILANA; LEE, 2014) e que irão emergir nas trocas comunicativas entre

\footnotetext{
${ }^{17}$ Fenômeno descrito pela primeira vez nos Estados Unidos pelo sociólogo David Caplovitz na obra Poor pay more, de 1963 (PRAHALAD; HART, 2002).
} 
os negócios sociais e seus públicos. Apesar da dificuldade em se definir um formato organizacional padronizado e das possíveis ambiguidades resultantes da combinação de características de negócios tradicionais e organizações sociais, Comini, Barki e Aguiar (2013) apontam que o interesse por negócios sociais é cada vez maior.

Figura 4 - Escala de negócios híbridos

Hybrid Spectrum

\begin{tabular}{|c|c|c|c|c|c|}
\hline $\begin{array}{c}\text { Traditional } \\
\text { Nonprofit }\end{array}$ & $\begin{array}{c}\text { Nonprofit } \\
\text { with Income- } \\
\text { Generating } \\
\text { Activities }\end{array}$ & $\begin{array}{c}\text { Social } \\
\text { Enterprise }\end{array}$ & $\begin{array}{c}\text { Socially } \\
\text { Responsible } \\
\text { Business }\end{array}$ & $\begin{array}{c}\text { Corporation } \\
\text { Practicing } \\
\text { Social } \\
\text { Responsibility }\end{array}$ & $\begin{array}{c}\text { Traditional } \\
\text { For-Profit }\end{array}$ \\
Income reinvested in social programs \\
Or operational costs \\
Stakeholder Accountability
\end{tabular}

Fonte: Alter (2007, p. 14).

Com ações voltadas à redução da pobreza, Yunus (2007, 21, tradução nossa) explica que é necessário ampliar o nosso próprio entendimento de economia "a fím de melhor servir estas comunidades de forma a redefinir as noções tradicionais de crédito, reafirmando o auto-emprego e criando negócios sociais" ${ }^{18} . \mathrm{O}$ economista vai na contramão dos autores citados anteriormente: ele entende que maximizar lucros e alcançar impacto social são objetivos conflitantes e inconciliáveis. Não seria possível haver organizações híbridas; por isso, Yunus defende que os lucros de um negócio social devem ser reinvestidos no próprio empreendimento.

O Quintessa adota os quatro postulados da Carta de princípios para negócios de impacto no Brasil para reconhecer um negócio social: compromisso com a missão social e ambiental; com o impacto social e ambiental monitorado; com a lógica econômica; e com a governança efetiva (FORÇA TAREFA DE FINANÇAS SOCIAIS, 2015a). Os quatro princípios dos negócios sociais também são descritos no site da aceleradora:

[negócios de impacto] 1) Têm como propósito gerar impacto socioambiental positivo (explícito em sua missão)

2) Conhecem, mensuram e avaliam seu impacto periodicamente

3) Geram receitas próprias a partir da comercialização de produtos e serviços

\footnotetext{
${ }^{18}$ No original: "to best serve these communities by redefining traditional notions of credit, reaffirming selfemployment and creating social business".
} 
4) Possuem uma governança que leva em consideração os interesses de investidores, de clientes e da comunidade (não fazem o que fazem a qualquer custo $)^{19}$

Para o Quintessa, a geração de impacto socioambiental e a sustentabilidade financeira devem estar presentes na atividade principal da organização, de forma que ambos os aspectos estejam alinhados. A aceleradora atende tanto organizações com fins lucrativos quanto negócios que distribuem dividendos para acionistas, desde que alinhados a um ou mais ODS.

\subsection{Negócios sociais e os Objetivos de Desenvolvimento Sustentável (ODS)}

Partimos da compreensão inicial de que, quando aliados aos ODS, os negócios sociais contribuem efetivamente para alcançar os objetivos comuns de desenvolvimento socioambiental. Isso porque, em primeiro lugar, os estudos sobre negócios sociais produzidos na América Latina reforçam a ênfase dada por esses empreendimentos à solução de problemas sociais, ou seja, a ação dos negócios sociais como forma de contribuir para a sociedade e, principalmente, para as populações de baixa renda.

Hoje, esses empreendimentos estão presentes em segmentos bastante diversificados, o que contribuiu para que, nos últimos anos, começassem a ser reconhecidos como uma força importante para a agenda global de sustentabilidade. A organização Pipe Social (O RETRATO..., 2019), ao mapear o setor, define as áreas de impacto dos negócios sociais com base nos ODS, consolidadas em seis vertentes de efeito socioambiental: cidadania, cidades, educação, serviços financeiros, saúde e tecnologias verdes.

A contribuição dos negócios sociais para a sustentabilidade ganhou o reconhecimento e apoio da Iniciativa Incluir: Inovação em Negócios e Mercados, cujo objetivo é fortalecer negócios que causem impacto socioambiental em nível local, regional e nacional. Criada em 2015 pelo PNUD, a Iniciativa Incluir promove pesquisas sobre o ecossistema de negócios sociais, oferece apoio a modelos de negócios sociais e inclusivos e auxilia no desenvolvimento de soluções de impacto socioambiental e na realização de encontros entre empresas, entidades e formuladores de políticas públicas.

Através da Iniciativa Incluir, o PNUD reconhece que o verdadeiro poder do setor privado vai muito além da Filantropia e da Responsabilidade Social; e que as empresas podem desenvolver soluções sustentáveis, inclusivas e

\footnotetext{
${ }^{19}$ Disponível em: https://www.quintessa.org.br/negocios-de-impacto. Acesso em: 13 ago. 2019.
} 
economicamente viáveis a favor das comunidades onde atuam (PNUD, 2019, n. p.).

A publicação The 2018 GlobeScan-SustainAbility Leaders, que monitora as práticas sustentáveis das organizações, perguntou a 729 especialistas de diferentes áreas de atuação e regiões do mundo quais são os segmentos organizacionais que mais contribuem para o desenvolvimento de uma agenda sustentável. Nesta consulta, os empreendedores sociais ficaram em segundo lugar, com $48 \%$ de menções, atrás apenas das organizações não governamentais (54\%). Em terceiro lugar aparecem as parcerias multisetoriais (42\%). O setor privado foi apontado por $28 \%$ dos entrevistados e as instituições financeiras por $21 \%$. O pior desempenho ficou por conta das organizações governamentais (8\%) (GLOBESCAN; SUSTAINABILITY, 2018).

A ANDE Brasil e o Instituto de Cidadania Empresarial (ICE) também estão entre as organizações que fomentam iniciativas empreendedoras capazes de gerar impacto positivo no Brasil. O setor conta ainda com o apoio do SEBRAE, entidade que se dedica a estimular o desenvolvimento de micro e pequenas empresas e que, mais recentemente, tem atuado no ecossistema de negócios sociais.

$\mathrm{O}$ atendimento do SEBRAE a esses empreendimentos envolve os seguintes eixos estratégicos: articulação com o ecossistema local; incentivo a uma cultura de inovação; desenvolvimento e implantação de gestão do conhecimento; promoção da capacidade interna e competências técnicas dos profissionais; geração de conteúdos e ferramentas de planejamento, gestão e avaliação de impacto; customização de cursos e capacitações; identificação de novas oportunidades de atuação para o SEBRAE; parcerias com universidades locais; e desenvolvimento e atualização de métricas de impacto social (SERVIÇO BRASILEIRO DE APOIO ÀS MICRO E PEQUENAS EMPRESAS, 2016). A entidade ressalta que os ODS "podem ser adotados como norteadores para o estímulo e apoio de negócios de impacto social que contribuam para o alcance dos objetivos" (SERVIÇO BRASILEIRO DE APOIO ÀS MICRO E PEQUENAS EMPRESAS, 2016, p. 31).

Os ODS foram aprovados em 2015 por líderes de Estado em Assembleia Geral da ONU e integram o documento Transformando nosso mundo: a Agenda 2030 para o desenvolvimento sustentável (PROGRAMA DAS NAÇÕES UNIDAS PARA O DESENVOLVIMENTO, 2016). São 17 objetivos e 169 metas em cinco dimensões entrelaçadas: pessoas, planeta, prosperidade, paz e parceria. Entre seus objetivos estão a erradicação da pobreza, a proteção dos recursos naturais, a garantia de vida próspera e em 
harmonia com a natureza, a promoção de sociedades pacíficas, justas e inclusivas e o incentivo à formação de redes colaborativas (Figura 5). Nações de todo o mundo firmaram o compromisso de atingir esses objetivos e metas até 2030.

Segundo a ONU, os ODS não se restringem aos Estados; as empresas também podem fazer uso dos objetivos e metas de sustentabilidade "como um quadro global para moldar, conduzir, comunicar e relatar as suas estratégias, objetivos e atividades, permitindo que essas tirem proveito de uma escala de benefícios" (GLOBAL REPORTING INITIATIVE; UNITED NATIONS GLOBAL COMPACT; WORLD BUSINESS COUNCIL FOR SUSTAINABLE DEVELOPMENT, [2015], p. 6). Tais benefícios incluem: identificar oportunidades futuras de negócios; valorizar a sustentabilidade corporativa; fortalecer relações com clientes, funcionários e outras partes interessadas a fim de desenvolver uma política de sustentabilidade; contribuir para um ambiente de negócios mais transparente e bem administrado; e, por fim, utilizar uma linguagem comum, estimulando parcerias para tratar de problemas sociais.

Figura 5 - Objetivos de Desenvolvimento Sustentável (ODS)

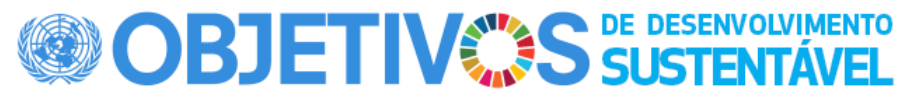
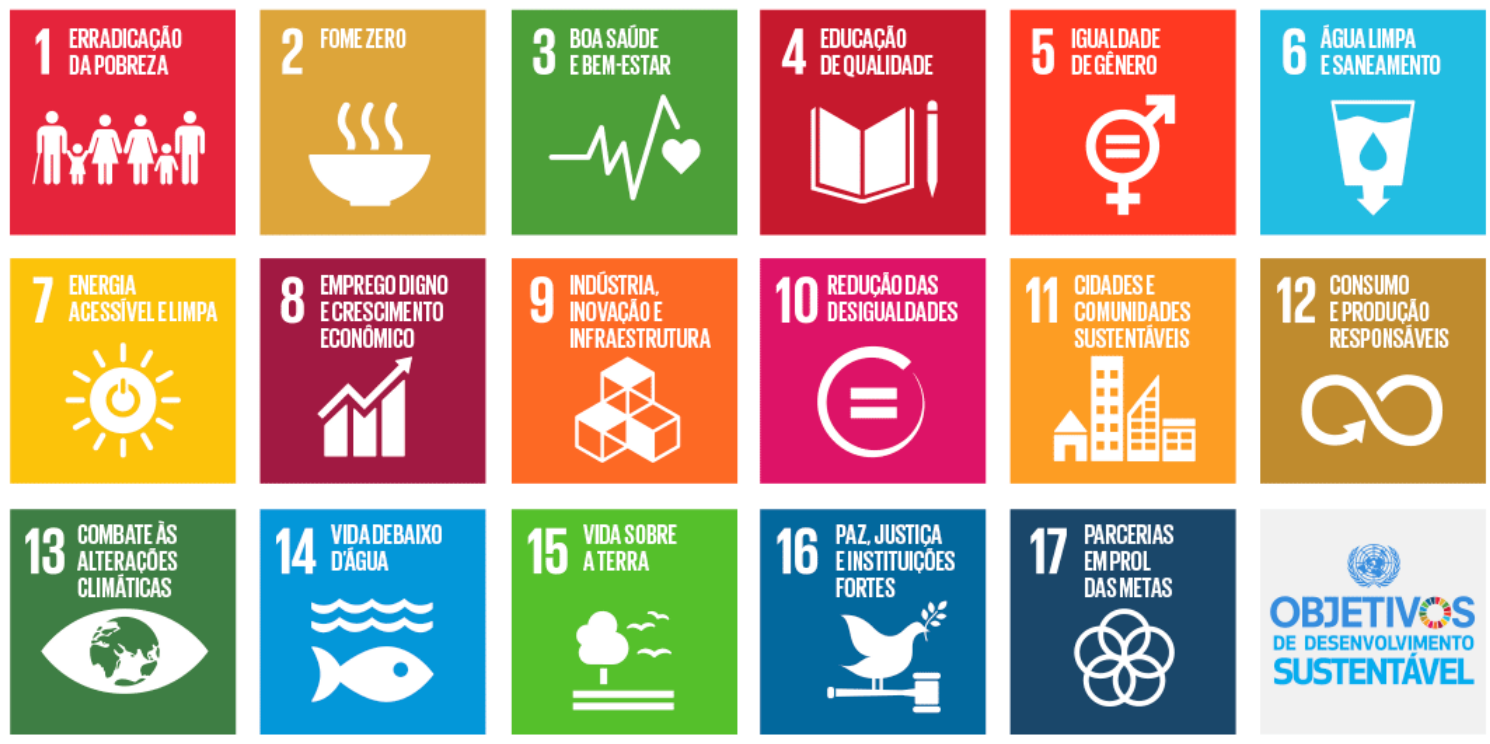

(6)

OBJETIVOS

DE DESENVOLVIMENTO SUSTENTÁVELL

Fonte: Brasil ([201-]). 
Os ODS têm sido uma referência importante para a agenda de sustentabilidade de Estados e grandes empresas. No Brasil, o Decreto $n^{\circ}$ 8.892/2016 criou a Comissão Nacional para os Objetivos de Desenvolvimento Sustentável, estabelecendo governança nacional para o processo de implantação da Agenda 2030 no país (BRASIL, 2016). No âmbito empresarial, "78\% das empresas que integram a Rede Brasil já estão alinhando suas estratégias de negócio com os objetivos globais" (REDE BRASIL DO PACTO GLOBAL; PROGRAMA DAS NAÇÕES UNIDAS PARA O DESENVOLVIMENTO, 2019, p. 5). Foi criado ainda o Grupo de Trabalho ODS, que tem como prioridades, em 2019, apresentar as contribuições do setor empresarial para o alcance dos Objetivos no Brasil, desenvolver um programa-piloto para integrar os ODS aos relatórios corporativos das empresas, e promover workshops para apresentar uma metodologia que integre os ODS às estratégias empresariais e iniciativas para alavancar o financiamento da Agenda 2030 (REDE BRASIL DO PACTO GLOBAL; PROGRAMA DAS NAÇÕES UNIDAS PARA O DESENVOLVIMENTO, 2019).

A despeito de tais iniciativas, o relatório Think global, trade local, do British Council e da Social Enterprise UK (2015), critica a ausência de metas dos ODS ligadas aos pequenos e médios negócios. O documento defende que não há um único caminho para o desenvolvimento sustentável e que empresas de todos os tamanhos podem desempenhar papel relevante para concretizar nossos objetivos sociais e ambientais comuns:

\begin{abstract}
A última versão dos ODS tem 17 objetivos e 169 metas associadas. No entanto, é falha ao não refletir o papel crítico dos negócios como um todo, principalmente do empreendedorismo social e dos negócios sociais. Há uma única referência para micro, pequenas e médias empresas. Embora sejam bemvindos, os ODS escolhem uma característica - o tamanho da empresa enquanto, ao mesmo tempo, não refletem como as empresas podem elas mesmas estar alinhadas com os objetivos ${ }^{20}$ (BRITISH COUNCIL; SOCIAL ENTERPRISE UK, 2015, p. 26, tradução nossa).
\end{abstract}

No mesmo ano em que é publicado o relatório, o próprio PNUD manifestou-se sobre o tema no Brasil, identificando os negócios sociais como "uma das possibilidades do setor privado trabalhar para os ODS" (PROGRAMA DAS NAÇÕES UNIDAS PARA O DESENVOLVIMENTO; FUNDAÇÃO DOM CABRAL, 2015, p. 8) em dois aspectos principais: inclusão social e sustentabilidade ambiental. Também a Carta de princípios

\footnotetext{
${ }^{20}$ No original: "The latest draft of the SDGs has 17 goals and 169 associated targets. Yet it fails to reflect the critical role of business at all, let alone that of responsible trading social entrepreneurship and social enterprise. There is one reference to micro, small and medium sized business. While welcome, the SDGs pick out one characteristic of enterprise - size - while at the same time failing to reflect how businesses may be aligned with the goals themselves".
} 
para negócios de impacto no Brasil procura alinhar as agendas dos negócios sociais com os ODS nas 15 recomendações aos atores do ecossistema, ligadas a princípios, apoio, geração de conhecimento e expansão de linhas de crédito para os negócios sociais (FORÇA TAREFA DE FINANÇAS SOCIAIS, 2015a).

Em 2017, o PNUD publicou, em parceria com o SEBRAE, o documento Retrato dos pequenos negócios inclusivos e de impacto no Brasil, em que ressalta a contribuição de pequenos negócios - estruturados e competitivos - para os ODS:

\begin{abstract}
Sabemos que 34 em cada 100 brasileiros adultos possuem uma empresa ou estão envolvidos com a criação de um negócio próprio. Soma-se a isto a contribuição incontestável dos pequenos negócios para o desenvolvimento do país ao responderem por $27 \%$ do PIB e $51 \%$ dos postos de trabalho. Desta forma, desempenham um papel vital para promover o crescimento econômico inclusivo e sustentável, o emprego e o trabalho decente, bem como impulsionar a produção sustentável e fomentar a inovação (PROGRAMA DAS NAÇÕES UNIDAS PARA O DESENVOLVIMENTO; SERVIÇO BRASILEIRO DE APOIO ÀS MICRO E PEQUENAS EMPRESAS, 2017, p. 3).
\end{abstract}

O estudo mapeou 837 iniciativas, identificando os ODS com mais negócios no Brasil. São eles: o ODS 8 ("Emprego digno e crescimento econômico"), ODS 3 ("Boa saúde e bem-estar") e ODS 4 ("Educação de qualidade"). Os negócios brasileiros também colaboram de forma significativa com o ODS 12 ("Consumo e produção responsáveis) e o ODS 10 ("Redução das desigualdades"), uma vez que também empregam frequentemente pessoas que se encontram à margem do mercado de trabalho. Em média, as iniciativas mapeadas pelo estudo declararam estar alinhadas com 4,9 ODS (PROGRAMA DAS NAÇÕES UNIDAS PARA O DESENVOLVIMENTO; SERVIÇO BRASILEIRO DE APOIO ÀS MICRO E PEQUENAS EMPRESAS, 2017).

A contribuição efetiva dos negócios sociais para a Agenda 2030 passa, necessariamente, por questão recorrente entre os atores do ecossistema e pesquisadores da área: a geração de valor e a mensuração de impacto socioambiental. Os estudos consultados apontam que essa questão em negócios sociais necessita de modelos e métricas de avaliação diferentes das empresas tradicionais, que não levem em conta somente aspectos econômicos do negócio.

Para fins desta pesquisa, impacto social é definido como o "efeito de uma atividade no tecido social de uma determinada comunidade e suas influências no bemestar dos indivíduos e famílias que a compõe" (OLIVEIRA FILHO; KIYAMA; COMINI, 2013, p. 213). As avaliações de impacto, por sua vez, "procuram responder a questões de causa e efeito. Em outras palavras, buscam mudanças nos resultados (outcomes) que são 
diretamente atribuídas ao programa" (GERTLER et al., 2010 apud BRANDÃO; CRUZ; ARIDA, [2014], p. 6).

Ao analisar 33 negócios sociais ibero-americanos, Portocarrero e Delgado (2010) destacaram quatro dimensões pelas quais puderam avaliar o valor social gerado pelos empreendimentos:

a) aumento da renda, por meio de estratégias de geração de emprego ou autoemprego, interação com fornecedores da cadeia produtiva e oferta de recursos aos empreendedores;

b) acesso a produtos e serviços para pessoas de baixa renda que, até então, não eram atendidas pela iniciativa privada (ou eram mal atendidas pelo setor público);

c) construção de cidadania, diminuindo a assimetria de informação, poder e influência em negócios que eliminam intermediários, oferecendo acesso ao mercado formal e à informação para o exercício dos direitos individuais; e

d) desenvolvimento de capital social em negócios que estimulam a inclusão de pessoas no mercado de trabalho e fortalecem grupos sociais.

Em sua análise, Portocarrero e Delgado (2010) também ressaltam a importância de avaliar aspectos tangíveis e intangíveis dos resultados alcançados pelos negócios sociais. Comini, Barki e Aguiar (2013), por sua vez, enfatizam a avaliação dos resultados alcançados pelos negócios sociais em longo prazo, e não somente pelo seu impacto imediato.

Uma das dificuldades em mensurar o impacto social é isolar a contribuição da empresa sobre os aspectos sociais e ambientais (SILVA; GONÇALVES-DIAS, 2015). Diversos indicadores permitem aos empreendedores sociais "selecionar métricas mais pertinentes às especificidades das atividades que seus negócios sociais demandam" (SILVA; GONÇALVES-DIAS, 2015, p. 128), o que, por outro lado, dificulta a comparação entre os empreendimentos.

Nesse sentido, a mensuração de impacto social requer "definir uma clara relação de causa e efeito e isolar outros fatores que podem ter gerado impacto social" 21 (KHANDKER et al., 2010 apud BARKI et al., 2015, p. 381, tradução nossa). É preciso

\footnotetext{
${ }^{21}$ No original: "to define clearly cause-effect relationships and isolating other causes that might have been the cause of the social impact".
} 
considerar ainda que, a despeito de indicadores e metodologias de avaliação, é necessário compreender a quais atributos os públicos estratégicos dos negócios sociais atribuem valor (OLIVEIRA FILHO; KIYAMA; COMINI, 2013). Tais públicos incluem investidores, empreendedores e os públicos beneficiados pelos negócios sociais, compreendidos, por meio de processos comunicativos, em suas diferenças estruturais e culturais.

\subsection{O ecossistema de negócios sociais no Brasil}

O termo "ecossistema" tem sido usado por pesquisadores brasileiros e estrangeiros para se referir ao ambiente em que se inserem os negócios sociais. Com origem nas ciências biológicas, o termo refere-se, neste contexto em particular, a uma comunidade econômica formada por diferentes organizações que interagem entre si e em torno de uma cadeia de valor de produção de bens ou serviços. Descreve, assim, "a forma como indivíduos, empresas, organizações e governos interagem para influenciar o desenvolvimento de empreendedores interrelacionados e suas empresas em uma única área metropolitana ou região local” (MORRIS, 2015 apud ENDEAVOR INSIGHT, 2016, p. 4).

A denominação "setor 2.5" também é comum para se referir ao ecossistema de negócio sociais, aludindo às características combinadas do segundo setor, ou seja, de empresas privadas com foco em geração de lucro, e do terceiro setor, de organizações sem fins lucrativos com o propósito de gerar impacto socioambiental positivo, conforme descrito em documentação cedida pelo Quintessa. Em sua segunda edição, o guia enumera 34 iniciativas de apoio aos negócios sociais que "podem fortalecer os negócios através do estímulo a competências referentes a vendas e gestão" (KIYAMA; COMINI; D’AMARIO, 2014, p. 14) em diferentes frentes de atuação e nos seus vários estágios, conforme resume a Figura 6.

No Brasil, o ecossistema de negócios sociais é formado por diferentes atores que se aproximam pelo propósito que mantêm em comum (ENDEAVOR INSIGHT, 2016), mesmo que não pertençam a uma mesma indústria ou segmento do mercado. São fundos de investimento, fundações, pesquisadores e empreendimentos sociais de áreas como saúde, educação, moradia, reciclagem, bens de consumo etc. Também compõem o ecossistema atores que estimulam a ação dos empreendedores sociais - por exemplo, 
aceleradoras, incubadoras, programas de inovação do setor público, family offices, entre outros. A Força Tarefa de Finanças Sociais enumera 28 atores-chave do ecossistema de negócios sociais (Quadro 2), apresentando para sua atuação recomendações específicas.

Figura 6 - Tipo de suporte oferecido aos empreendedores por organizações de apoio aos negócios sociais

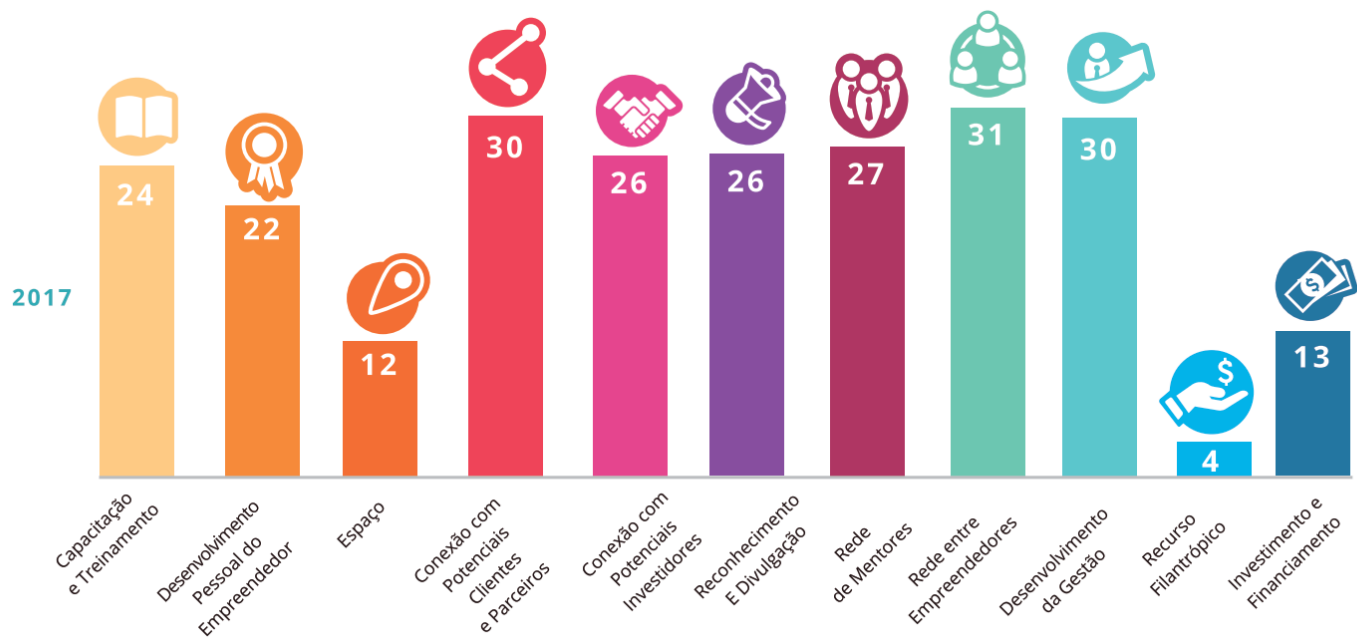

Fonte: Quintessa (2017)

Quadro 2 - Atores-chave do ecossistema de negócios sociais

\begin{tabular}{|l|l|}
\hline $\begin{array}{l}\text { Associação Brasileira de Private Equity e Venture } \\
\text { Capital (ABVCAP) }\end{array}$ & $\begin{array}{l}\text { Fundações e institutos (empresariais e } \\
\text { familiares) }\end{array}$ \\
\hline Agências de fomento à pesquisa & Fundos de investimento \\
\hline $\begin{array}{l}\text { Associação Nacional de Entidades Promotoras de } \\
\text { Empreendimentos Inovadores (Anprotec) }\end{array}$ & Fundos sociais \\
\hline Avaliadores/auditores/certificadores independentes & $\begin{array}{l}\text { Grupo de Institutos, Fundações e Empresas } \\
\text { (GIFE) }\end{array}$ \\
\hline Banco Central & Governo (federal, estadual e municipal) \\
\hline Bancos comerciais e de investimento & Incubadoras e aceleradoras \\
\hline $\begin{array}{l}\text { Banco Nacional de Desenvolvimento Econômico e } \\
\text { Social (BNDES) }\end{array}$ & Indivíduos de alta renda \\
\hline Comissão de Valores Mobiliários & Instituições de Ensino Superior (IES) \\
\hline Empreendedores de negócios de impacto & Ministério Público \\
\hline Empresas & ONGs que atuam na gestão pública \\
\hline Estudantes de graduação e pós-graduação & $\begin{array}{l}\text { Órgãos de controle (Ministério Público Federal, } \\
\text { Tribunal de Contas da União, Advocacia-Geral } \\
\text { da União etc.) }\end{array}$ \\
\hline Family offices & Organismos multilaterais de crédito \\
\hline Financiadora de Estudos e Projetos (FINEP) & Professores \\
\hline Firmas de investimento (gestores ou distribuidores) & SEBRAE \\
\hline Fonte: Adaptado de Força Tarefa de Finanças Sociais & (2015b). \\
\hline
\end{tabular}


Para Reficco e Vernis (2010, p. 129), “a metáfora de ecossistema ajuda a comunicar de forma clara a complementariedade e interdependência que existe entre os membros de uma comunidade de interesses" ${ }^{22}$, ressaltando a conexão íntima entre uma organização e o seu contexto e a condição de vulnerabilidade de organizações que estão isoladas do ambiente externo. Segundo eles, os atores sociais ligados à cadeia de valor estão no centro do ecossistema, pois deles depende a produção de bens e serviços (REFICCO; VERNIS, 2010). Também figuram no ecossistema os órgãos reguladores e apoiadores, assim como outros atores, como concorrentes, grupos de interesse e produtores de bens complementares ou substitutos.

A literatura sobre o tema irá, assim, reforçar o vínculo entre os negócios sociais e o ambiente em que estão inseridos, seja pelas características da economia local, seja pelas necessidades específicas daquela comunidade. Para Barki e Aguiar (2013), os negócios sociais são consequência de diferentes pressões do ambiente em que estão inseridos: da sociedade, que cobra um papel social das organizações; dos funcionários, especialmente a geração mais jovem, que buscam desenvolver iniciativas mais inovadoras e inclusivas; dos negócios, ou seja, de um mercado da base da pirâmide que demanda organizações mais próximas de consumidores e comunidades. Neste cenário, os ecossistemas locais, pela sua capacidade de se articular com diferentes atores e de criar redes de relações confiáveis entre as organizações, têm forte influência no desenvolvimento de modelos de negócios (REFICCO; VERNIS, 2010).

A literatura também destaca a importância de estabelecer redes e alianças amplas para o sucesso dos negócios sociais, apontando que "o setor privado, o terceiro setor e o setor público são parceiros naturais nessa construção" (COMINI; BARKI; AGUIAR, 2013, p. 63). No terceiro setor, por exemplo, a parceria com os negócios sociais permite possibilita o desenvolvimento de ações com impacto positivo em comunidades locais (BARKI; AGUIAR, 2013). Essa é perspectiva semelhante à de Fischer (2002), segundo a qual, no Brasil, a formação de alianças para uma atuação com foco social já é recorrente entre as empresas (por meio de seus programas de responsabilidade social), nas organizações do terceiro setor (há mais tempo em atuação no país) e em instituições públicas. "Estes atores reconheceram que a colaboração intersetorial é condição necessária para viabilizar um desenvolvimento sustentável” (COMINI, 2016, p. 23).

\footnotetext{
22 No original: "La metáfora del ecosistema ayuda a comunicar en forma clara la complementariedad e interdependencia que existe entre los miembros de una comunidad de intereses".
} 
Oliveira e Nader (2017, p. 49), por sua vez, reforçam entre os empreendedores sociais "a importância da estruturação de laços sociais, permitindo a atuação em rede e ampliação de seu impacto para o alcance dos objetivos de transformação social", dado que esses empreendimentos requerem concepção coletiva, participativa e engajada de trabalho, visando o interesse público.

A posição dos autores é reforçada pela recomendação da ONU quanto à implementação dos ODS na estratégia dos negócios. Segundo a entidade, “cada vez mais empresas engajam em parcerias com sua rede de fornecedores, com empresas do seu setor, e até com governos e organizações da sociedade civil" para alcançar os ODS e contribuir para a solução de problemas sociais sistêmicos (GLOBAL REPORTING INITIATIVE; UNITED NATIONS GLOBAL COMPACT; WORLD BUSINESS COUNCIL FOR SUSTAINABLE DEVELOPMENT, [2015], p. 7). O documento recomenda às empresas explorar ao menos três tipos de parcerias: entre líderes de um mesmo segmento de mercado, num esforço para mudar práticas da indústria como um todo; dentro da cadeia de valor, a fim de desenvolver novas soluções para o mercado; e com diversas partes interessadas (governos, terceiro setor e sociedade civil) para enfrentar desafios complexos.

Numa visão mais crítica do ecossistema, Oliveira Filho, Kiyama e Comini (2013, p. 211-212) afirmam que os atores do ecossistema de negócios sociais "estão sendo tratados como parte de um todo que na prática não existe, a não ser pelo fato de que todos buscam possibilidades de servir da melhor forma possível a população de baixa-renda". Já Reficco e Vernis (2010, p. 153) defendem que as relações no ecossistema de negócios inclusivos se pautem pela "amistad de negocio", ou seja, por um relacionamento próximo, personalizado e perene entre os atores sociais, em oposição a uma simples transação comercial, e pela "intimidad de negocio", quando empresa e comunidade estabelecem um compromisso recíproco com o desenvolvimento mútuo em longo prazo.

Reficco e Vernis (2010) também defendem a importância de identificar e compreender a rede de relações do ecossistema, a fim de constituir plataformas colaborativas permanentes ou pontuais para os negócios inclusivos. Advogam ainda a necessidade de reconhecer as estruturas, lideranças e normas existentes; harmonizar expectativas, reduzir incertezas e definir com clareza compromissos e papéis desempenhados pelos atores sociais; e assegurar a apropriação do negócio por parte da comunidade, identificando-a como parte integrante e participativa do ecossistema e explorando as capacidades e particularidades de cada lugar. Ressaltam, por fim, a 
importância de os negócios inclusivos estabelecerem, em longo prazo e com base na confiança mútua, relações mais humanizadas e benéficas a ambas as partes, aspecto para o qual a comunicação será indispensável.

\subsubsection{As aceleradoras de negócios sociais}

Geralmente, potenciais empreendedores no segmento de negócios sociais costumam se enquadrar em uma destas duas vertentes principais: trata-se de pessoas ligadas ao terceiro setor, com propósito de causar impacto social, mas sem experiência nos negócios; ou pessoas do segundo setor que estão buscando constituir um empreendimento que visa solucionar problemas socioambientais, mas com pouca experiência nestas temáticas (SERVIÇO BRASILEIRO DE APOIO ÀS MICRO E PEQUENAS EMPRESAS, 2016). Neste contexto, ganharam espaço no ecossistema de negócios sociais as aceleradoras ou incubadoras, que são "organizações que t[ê]m como objetivo facilitar e acelerar o amadurecimento e consolidação de empreendimentos sociais" (COMINI, 2016, p. 33).

As aceleradoras de negócios sociais atuam em um problema comum aos empreendedores sociais: a dificuldade em gerar rendas iniciais para o negócio, que nessa fase incipiente costuma ser marcado pela experimentação e adaptação (KIYAMA; COMINI; D’AMARIO, 2014). Também é recorrente, durante esse processo, que os empreendedores mudem sua ideia original de negócio após o contato com aceleradoras ou outras organizações de apoio e possíveis sócios.

As aceleradoras costumam manter programas de aceleração próprios, para os quais selecionam um número limitado de negócios por meio de chamada pública, prospecção de empreendedores ou ficha de cadastro em seus sites institucionais. O empreendimento selecionado tem então seu modelo de negócios e suas operações otimizados pela metodologia da aceleradora. O tempo de aceleração pode variar conforme o estágio de maturação do negócio. Em troca desse suporte, o empreendedor remunera a aceleradora, podendo optar por formas variadas, como taxas fixas, percentual do faturamento ou mensalidade. Entre os serviços oferecidos estão treinamento e consultoria, auxiliando no desenvolvimento de planos de negócios, apoio na replicação do modelo de negócios criado pela organização ou, ainda, suporte para expandir.

Esse tipo de organização de apoio aos empreendedores difere das incubadoras no que se refere ao estágio do negócio e ao tempo de aceleração: as incubadoras dão 
suporte às empresas nascentes (startups) na fase inicial do ciclo de negócios e por períodos mais longos (dois ou três anos), enquanto as aceleradoras dão apoio a negócios em crescimento e por um período menor (LIMEIRA, 2014).

No caso das incubadoras, também são identificadas aquelas de base tecnológica, que apoiam o desenvolvimento de negócios e soluções em tecnologia e inovação. Segundo Ribeiro, Andrade e Zambalde (2005), o objetivo destas organizações é dar suporte a pequenas e microempresas do ramo, oferecendo instalações físicas, redes de contatos e consultoria e facilitando a interação com centros de ensino e pesquisa, tornando a região em que atuam mais competitiva no mercado. Mesmo entre as aceleradoras, negócios que envolvem alguma tecnologia tendem a ser mais aceitos em programas de aceleração (O RETRATO..., 2019).

No ecossistema dos negócios sociais, aceleradoras e incubadoras são muito semelhantes, sendo que a diferença mais significativa entre elas é que as aceleradoras têm maior chance de receber investimentos para empresas do seu portfólio, segundo o estudo O panorama das aceleradoras e incubadoras no Brasil, publicado em 2017 pela ANDE Brasil em parceria com o ICE (DAVIDSON et al., 2017). O documento apresenta algumas características desta modalidade de organização de apoio: as aceleradoras normalmente oferecem programas de aceleração mais curtos, privilegiam negócios que causem impacto socioambiental e atuam principalmente nos segmentos de educação, meio ambiente e serviços financeiros (DAVIDSON et al., 2017), que hoje são os principais setores para investimento de impacto no Brasil (DUMONT et al., 2016).

Para fins deste estudo, optamos pelo termo "aceleradora", com o qual o Quintessa se autodenomina. Em seu programa de aceleração, o Quintessa contribui com empreendedores em estágio de validação, tração ou escala do negócio nas seguintes frentes: desenvolvimento pessoal do empreendedor, conexão com eventuais parceiros, clientes e potenciais investidores, reconhecimento e divulgação, rede de mentores, rede de empreendedores e desenvolvimento da gestão, sendo este último apontado como diferencial da aceleradora no ecossistema de negócios sociais.

As aceleradoras também costumam manter parcerias estratégicas - formais e informais - com perfil diversificado de organizações, tais como investidores, profissionais especializados, empresas, negócios sociais e outras entidades do ecossistema de negócios sociais (LIMEIRA, 2014). Essas parcerias geram oportunidade de negócios, investimentos, estudos, eventos para debater o setor, chamadas para projetos e serviços de consultoria e mentoria, entre outros. 
Em estudo qualitativo sobre o papel das aceleradoras no desenvolvimento de negócios sociais no Brasil, Limeira (2014) identificou, entre os desafios do setor:

- o número reduzido de negócios baseados em modelos sustentáveis, do ponto de vista econômico;

- a falta de metodologias apropriadas para mensurar o impacto social; e

- a falta de capacitação para encontrar oportunidades de financiamento para os negócios acelerados.

Quanto ao número reduzido de iniciativas empreendedoras baseadas em modelos sustentáveis de negócio, uma das hipóteses para este problema é o pouco apoio aos empreendimentos em estágios iniciais. O Guia 2.5 identifica um total seis estágios que compõem o ciclo de vida de um negócio social:

1) exploração de ideias para um negócio;

2) refinamento da ideia e validação do negócio, com foco no cliente;

3) prototipagem do produto ou serviço, com foco na necessidade do cliente;

4) início de vendas e validação do negócio, com foco em acesso ao mercado;

5) estruturação da gestão e refinamento do modelo de negócios; e

6) expansão do negócio (QUINTESSA, 2017).

Observamos, pela análise do documento cedido pelo Quintessa, que as iniciativas de apoio aos negócios sociais estão concentradas majoritariamente nos estágios 4, 5 e 6, quando o foco é se lançar no mercado, refinar o modelo de negócios e ganhar escala.

Quanto à mensuração de impacto, publicação da International Business Innovation Association (INBIA), rede global para incubadoras, aceleradoras e centros de empreendedorismo, desenvolveu um modelo de avaliação (Figura 7) em que recomenda "mapear quais produtos e serviços cada empresa utiliza e então usar ferramentas estatísticas para distinguir a contribuição de certos programas"23 (RENAULT, 2017, p. 18, tradução nossa), a fim de medir sua efetividade nos negócios acelerados, contribuir para a gestão, comunicar melhor os resultados alcançados e justificar propostas de investimento para parceiros estratégicos.

\footnotetext{
${ }^{23}$ No original: "to track which products and services each company uses, and then use statistical tools to distinguish the contribution of certain programs".
} 
Figura 7 - Modelo de avaliação de programas de aceleração

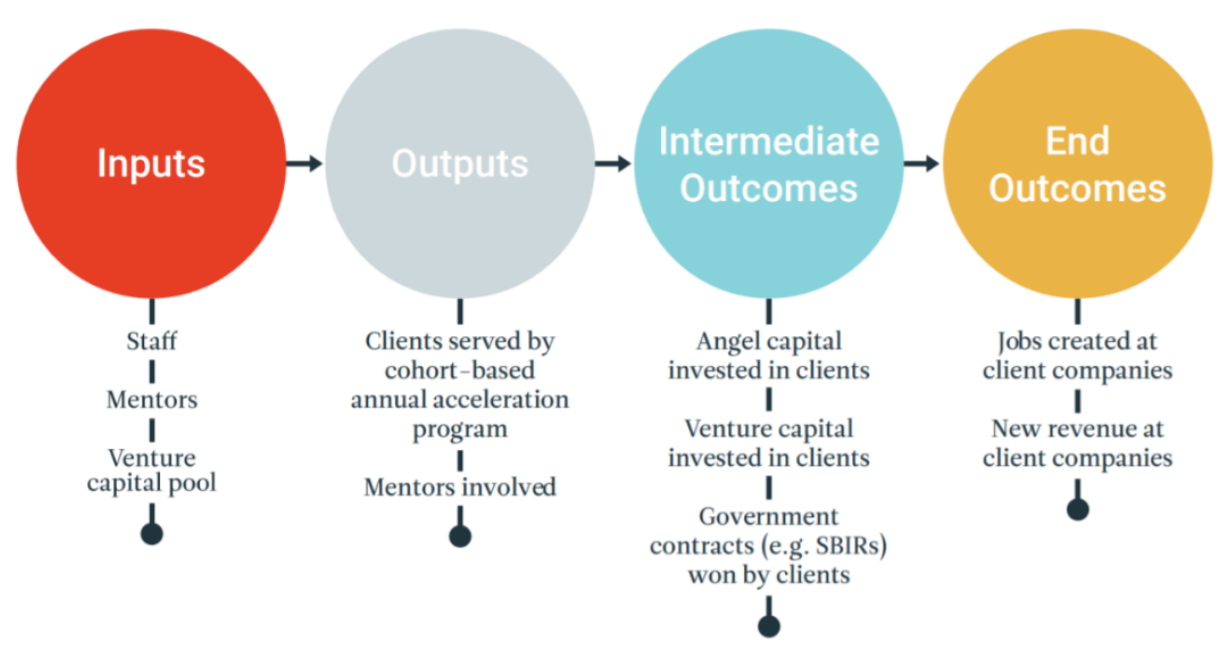

Fonte: Renault (2017, p. 13).

Quanto à incapacidade para obter financiamento, o relatório Panorama do setor de investimento de impacto na América Latina, de 2016, entrevistou investidores de impacto social que relataram ter dificuldades de encontrar empreendedores qualificados e identificar parceiros técnicos que pudessem auxiliá-los, o que leva muitos investidores a oferecer atividades de assistência junto com o investimento (DUMONT et al., 2016).

De acordo a Pipe Social (O RETRATO..., 2019), são necessárias mais oportunidades de aceleração de negócios sociais no Brasil. O estudo revela que $50 \%$ dos negócios consultados já buscaram programas de aceleração e incubação, mas não tiveram sucesso. Outros 30\% dos negócios afirmaram já terem sido acelerados uma vez, e 11\% nunca participaram nem têm interesse em ser acelerados. O levantamento também aponta que é preciso elaborar programas de aceleração mais customizados e adequados às necessidades específicas do segmento de atuação, do momento do negócio e da problemática principal do empreendedor.

\subsection{Desafios para os negócios sociais na contemporaneidade}

Kiyama, Comini e D’Amario (2014, p. 14) apontam para a necessidade de fortalecer o ecossistema de negócios sociais, "fazendo com que novos empreendedores, exemplos de sucesso, organizações apoiadoras e clientes corporativos se aproximem a fim de facilitar a jornada das pessoas que iniciam negócios sociais", aumentando suas 
chances de êxito. Perspectiva semelhante têm os investidores de impacto social, que citam o isolamento do setor como um dos desafios a serem enfrentados pelo ecossistema de negócios sociais:

Iniciativas que promovem o diálogo e a cooperação entre diferentes organizações são fundamentais para o setor de investimentos de impacto. Apesar de existirem algumas iniciativas que buscam uma abordagem mais unificada, a comunicação entre os membros do setor ainda precisa ser aprimorada ${ }^{24}$ (DUMONT et al., 2016, p. 72, tradução nossa).

Tal isolamento dos empreendedores, sentido, sobretudo, na gestão e ao dar escala aos seus negócios, é indicador da necessidade de maior apoio do ecossistema (PROGRAMA DAS NAÇÕES UNIDAS PARA O DESENVOLVIMENTO; SERVIÇO BRASILEIRO DE APOIO ÀS MICRO E PEQUENAS EMPRESAS, 2017). A baixa difusão do conceito de negócios sociais pelos próprios empreendedores (atuais e potenciais) e o seu pouco conhecimento sobre instituições de apoio existentes são desafios do setor (SERVIÇO BRASILEIRO DE APOIO ÀS MICRO E PEQUENAS EMPRESAS, 2016). Também é necessário que o ecossistema de negócios sociais inclua profissionais qualificados e de diferentes áreas do conhecimento, conforme as necessidades dos empreendedores sociais (SERVIÇO BRASILEIRO DE APOIO ÀS MICRO E PEQUENAS EMPRESAS, 2013).

O setor ainda opera com número relativamente baixo de soluções de inovação social, de base tecnológica ou não, voltadas, sobretudo, para atender pessoas de menor renda. Os negócios sociais que puderem estabelecer um elo entre tecnologia (principalmente tecnologias verdes) e impacto social aumentarão as chances de potencializar e expandir (PROGRAMA DAS NAÇÕES UNIDAS PARA O DESENVOLVIMENTO; FUNDAÇÃO DOM CABRAL, 2015). Num contexto em que cresce o uso de tecnologias por parte das camadas de renda média e baixa da população, os negócios sociais também devem otimizar o uso de tecnologias para viabilizar o acesso e distribuição dos produtos e serviços para a base da pirâmide.

A inovação social também pode estar ligada à reconfiguração das relações sociais para "maior empoderamento e mobilização política de população marginalizada no desenho das soluções" (COMINI, 2016, p. 57) ou, ainda, à inovação de processos, por exemplo, pela tendência recente de facilitar o acesso ao crédito por meio de plataformas e instrumentos coletivos (O RETRATO..., 2019).

\footnotetext{
${ }^{24}$ No original: "Initiatives that promote dialogue and cooperation between different organizations are fundamental to the impact investing field. Despite the existence of some initiatives striving for a more united approach, communication between members of the ecosystem still needs to improve".
} 
Um dos desafios dos negócios sociais é ter a sua importância reconhecida para colaborar com os nossos objetivos comuns - expressos nos ODS -, para a qual é necessário consolidar indicadores de impacto social. Nesse sentido, os negócios sociais podem se beneficiar da maior visibilidade dada ao setor, hoje restrita a poucos empreendimentos (SERVIÇO BRASILEIRO DE APOIO ÀS MICRO E PEQUENAS EMPRESAS, 2016), a partir da interação com órgãos locais e globais, tais como o SEBRAE e o PNUD. Além disso, negócios que articulam impacto social e valor ambiental poderão se fortalecer e trazer um diferencial ao seu core business (PROGRAMA DAS NAÇÕES UNIDAS PARA O DESENVOLVIMENTO; FUNDAÇÃO DOM CABRAL, 2015).

O financiamento de negócios sociais é outro tópico que preocupa o ecossistema. A notícia recente de que "o maior fundo de investimento do mundo - o americano BlackRock - se comprometeu a concentrar seus investimentos em negócios e ativos de impacto social" (SCHELLER, 2019, n. p.) é avaliada como um sinal positivo do mercado, ainda que os investimentos estejam restritos às áreas de meio ambiente, saúde e educação. O investimento de impacto como estratégia convencional nos mercados financeiros poderá vir a ser tendência também no Brasil, segundo investidores do setor (DUMONT et al., 2016), e poderá contar inclusive com capital estrangeiro (O RETRATO..., 2019).

Apesar da movimentação recente do mercado financeiro em torno da temática, o resultado do $2^{\circ}$ mapa de negócios de impacto social + ambiental, de 2019, mostra que a captação de recursos ainda é crítica entre os negócios sociais: a busca por recursos é o mais recorrente pedido de ajuda dos empreendedores, apontado em 48\% dos 1.002 negócios mapeados (O RETRATO..., 2019). Nesse sentido, os empreendedores necessitam de acesso facilitado e menos burocrático ao crédito, menores custos transacionais, novos modelos de investimento e relacionamento ampliado com investidores (SERVIÇO BRASILEIRO DE APOIO ÀS MICRO E PEQUENAS EMPRESAS, 2013). "Hoje, os empreendedores de impacto encontram diversas dificuldades para acessar recursos entre R \$ 100 mil e 1 milhão. Por sua vez, há recursos disponíveis para negócios mais estruturados e que precisam atingir escala", disse Helena Masullo, da Wright Capital (2 ${ }^{\circ}$ MAPA..., 2019, n. p.). Até que ponto atrelar a comunicação com investidores às intencionalidades e, principalmente, a contribuição dos resultados alcançados pelos negócios sociais aos ODS poderá alterar este cenário?

A ampliação da participação do setor público no ecossistema de negócios sociais também é defendida por uma parcela de atores da área, na forma de apoio aos novos 
negócios, disponibilização de fundos governamentais e criação de novas leis de incentivo aos investimentos de impacto (DUMONT et al., 2016), assim como o envolvimento de universidades na identificação de soluções tecnológicas e treinamento de empreendedores. Tais interações podem ajudar a reduzir a concentração de eventos em determinadas regiões do país, o que também é apontado como uma dificuldade para a disseminação da informação e a exposição mais diversificada dos empreendedores sociais (SERVIÇO BRASILEIRO DE APOIO ÀS MICRO E PEQUENAS EMPRESAS, 2016).

A parceria com grandes empresas configura oportunidade para os negócios sociais. Investidores do setor acreditam que "o crescente interesse geral sobre o impacto social e ambiental das empresas também está fomentando a expansão de investimentos de impacto"25 (DUMONT et al., 2016, p. 74, tradução nossa), o que se verifica em empresas que começam a integrar negócios sociais ao seu core business, em vez de restringir suas ações nesta área a departamentos de sustentabilidade e responsabilidade social.

Para isso, os negócios sociais precisam se integrar à cadeia produtiva e de suprimentos de empresas e governos (SERVIÇO BRASILEIRO DE APOIO ÀS MICRO E PEQUENAS EMPRESAS, 2013), a fim de ganhar escala e ampliar seu impacto por meio de estratégias para atingir plataformas Business-to-Government (B2G) e Businessto-Business (B2B). Nesse sentido, o alinhamento com os ODS é um passo importante, uma vez que as Nações Unidas recomendam às grandes empresas mapear toda a cadeia de valor a fim de identificar áreas de maior impacto social positivo ou negativo, tendo como referência os ODS e suas metas (GLOBAL REPORTING INITIATIVE; UNITED NATIONS GLOBAL COMPACT; WORLD BUSINESS COUNCIL FOR SUSTAINABLE DEVELOPMENT, [2015]). Nesse sentido, atores do ecossistema já começam a desenvolver modelos de apoio, patrocínio e pesquisa e desenvolvimento para empresas que queiram fazer parcerias com negócios sociais (O RETRATO..., 2019).

Em resumo, abordamos neste capítulo as origens dos negócios sociais, vinculadas a uma noção mais abrangente de desenvolvimento que contempla geração de valor socioambiental para a sociedade em detrimento de uma visão centrada em indicadores econômicos. Buscamos contextualizar amplamente o objeto de pesquisa, cercando os principais desafios e dificuldades apontados pelo setor. Discutimos conceitos e características dos negócios sociais a partir da proposição de negócios híbridos, que será

\footnotetext{
${ }^{25}$ No original: "The growing general interest in the social and environmental impact of companies is also driving expansion for impact investing".
} 
importante para compreender a comunicação organizacional em novos formatos e modelos de gestão. Da mesma forma, apresentamos a perspectiva de autores da área sobre o ecossistema de negócios sociais que, no decorrer desta pesquisa, associamos aos estudos sobre públicos, próprios do campo das relações públicas. 


\section{A COMUNICAÇÃO EM NEGÓCIOS SOCIAIS}

Neste capítulo são apresentados os referenciais teóricos da comunicação que darão as diretrizes para a nossa pesquisa empírica. Abordamos estudos sobre a comunicação integrada, eixo conceitual para o estudo do processo comunicativo em negócios sociais. Tendo em vista a natureza teórica e prática desta pesquisa, também apresentamos reflexões sobre políticas e estratégias de comunicação em negócios sociais e da classificação de públicos aplicada a esse ecossistema. Por fim, discutimos as possíveis contribuições para os estudos sobre o processo de comunicação em negócios sociais nas áreas de relações públicas comunitárias e comunicação para a sustentabilidade.

Para desenvolver este capítulo foram fundamentais as contribuições de Kunsch (1997, 2006, 2007a, 2009, 2016), Sabbatini (2007, 2010), França (2010, 2012), França e Ferrari, (2008), Grunig e Hunt (1984), Felizola et al. (2009), Vilaça (2012), Medrano (2007), Smith (2015), Smith, Gonin, Besharov (2013), Palmerston et al. (2004), Casali (2002), Deetz (2017, 2009), Peruzzo (1993) e Silva, Guedes e Santos (2017).

\subsection{A comunicação integrada em interface com os negócios sociais}

A comunicação integrada é a referência principal deste estudo para refletir sobre a comunicação dos negócios sociais. Os estudos sobre o tema inserem-se na grande área das ciências sociais aplicadas, na área da comunicação e subárea da comunicação organizacional. Tem origem no Brasil na década de 1980, à época da redemocratização do país, contexto semelhante, portanto, às origens dos negócios sociais. No campo acadêmico, somam-se aos estudos de viés interpretativo da comunicação organizacional, que tiveram forte crescimento no mesmo período, sobretudo na América Latina e na Europa (KUNSCH, 2006). Segundo Scroferneker (2006), o modelo interpretativo concebe as organizações como culturas, em que a comunicação é compreendida como um processo subjetivo de construção da realidade social. Os estudos interpretativos buscavam priorizar aspectos ainda pouco contemplados da comunicação organizacional, enfatizando práticas cotidianas, interações sociais e processos simbólicos.

É nesse contexto que se propõe uma comunicação integrada, defendida há anos em inúmeras obras de Kunsch $(1997,2006,2016)$, que hoje se dedica a compreender 
como a comunicação integrada pode contribuir para a gestão da sustentabilidade nas organizações.

Em primeiro lugar, cabe-nos apresentar a perspectiva da autora para a comunicação organizacional, que no Brasil possui diferentes abordagens conceituais. Para Kunsch (2016, p. 149), “a comunicação organizacional, como objeto de pesquisa, é a disciplina que estuda como se processa o fenômeno comunicacional dentro das organizações no âmbito da sociedade global". "Comunicação corporativa" ou “comunicação empresarial” são outros termos recorrentes na área, mas que, para a autora, são mais restritivos às atividades comunicacionais de empresas tradicionais.

A comunicação integrada, por sua vez, deve ser compreendida como uma filosofia e uma política de comunicação no âmbito das organizações. Em suma, ela “pressupõe uma junção da comunicação institucional, da comunicação mercadológica, da comunicação interna e da comunicação administrativa, que formam o mix, o composto da comunicação organizacional" (KUNSCH, 2016, p. 150). A comunicação integrada implica, portanto, na convergência de diferentes áreas da comunicação, com base em uma política global que deve estar alinhada aos objetivos gerais da organização. A comunicação integrada, portanto,

\begin{abstract}
procura contemplar uma visão abrangente da comunicação nas e das organizações, levando em conta todos aqueles aspectos relacionados com a complexidade do fenômeno comunicacional inerente à natureza das organizações, bem como os relacionamentos interpessoais, além da função estratégica e instrumental (KUNSCH, 2007, p. 47).
\end{abstract}

A comunicação integrada faz parte de uma macroestratégia do negócio, como "uma filosofia capaz de orientar e nortear toda a comunicação que é gerada na organização" (KUNSCH, 2016, p. 179), enquanto as táticas e ações ficam a cargo de cada uma das subáreas da comunicação. No caso dos negócios sociais, uma política global de comunicação deve estar alinhada aos objetivos sociais do negócio, ou seja, à solução que o negócio oferece para um problema social.

Elevar a comunicação a um nível estratégico é uma das grandes contribuições da comunicação integrada aos estudos da área. Segundo Vilaça (2012, p. 61), a comunicação integrada potencializa a atuação da área de comunicação nos empreendimentos a partir da compreensão de que a "comunicação somente faria sentido se fosse considerada estratégica para as organizações”. A comunicação deixaria de ser vista, assim, como um conjunto de ações isoladas e passaria a ser concebida como um processo que necessita de planejamento e direcionamento estratégicos, alinhando-se com 
os objetivos da organização (OLIVEIRA, 2015). Isso não significa, contudo, desconsiderar a inerência do conflito nas relações organizacionais; defende tão somente a adoção de uma comunicação integrada e não fragmentada (KUNSCH, 2006).

A comunicação integrada busca, assim, "dar conta da complexidade da comunicação das organizações com seus diferentes segmentos de públicos" (SCROFERNEKER, 2006, p. 52) ao afirmar que deve ser trabalhada de forma planejada e estratégica, em oposição à perspectiva recorrente nos estudos da época que privilegiavam a instrumentalidade da comunicação organizacional. Para isso, dois princípios são fundamentais: o envolvimento da diretoria e a inserção da comunicação no processo decisório da empresa.

Depois que Margarida Kunsch lançou o conceito na década de 1980 e o desenvolveu nos anos seguintes, outros autores da comunicação organizacional se debruçaram sobre a comunicação integrada. Bueno (2009, p. 126) afirma que a comunicação integrada "pressupõe a existência de diretrizes comuns para orientar a elaboração e implementação de diferentes ações, estratégias e produtos de comunicação de uma organização", com o objetivo de agregar valor a sua marca ou de consolidar a sua imagem perante seus públicos e a sociedade em geral.

Oliveira e Paula (2006) enfatizam na comunicação integrada a convergência de esforços para a criação de espaços comuns onde significados e sentidos são compartilhados entre as organizações e seus públicos. Geraldes (2014, p. 138) ressalta a “indissociabilidade entre tática, estratégia e políticas, constituindo uma comunicação que [...], com um foco na sustentabilidade, elabora seus produtos e processos a partir de valores, princípios, identidade e memória”. Outro ponto de vista é o de Felizola et al. (2009, p. 8-9) que em revisão sobre o conceito o abordam de forma mais racionalista:

\footnotetext{
definimos que a comunicação integrada é o processo de fomentar conteúdos relacionados à empresa, seus colaboradores e produtos, que envolve uma dinâmica conjugada de transmissão de informações, tanto no nível administrativo e interno, quanto no nível externo (institucional e mercadológico), proporcionando unicidade de conceitos, o que garante seu gerenciamento racional.
}

A comunicação integrada aplica-se a todo tipo de organização, seja ela pública ou privada, com ou sem fins lucrativos (KUNSCH, 2016), sendo este um dos motivos pelos quais a escolhemos para esta reflexão sobre o processo de comunicação em negócios sociais, que muitas vezes misturam elementos de empresas tradicionais e de organizações do terceiro setor. 
Entre as vantagens deste modelo de gestão comunicacional estão a maior eficácia de suas ações e táticas - planejadas a partir de uma política global - e o potencial de evitar a sobreposição de tarefas no âmbito da comunicação. Além disso, garante programas de comunicação mais coerentes para a "construção de uma identidade corporativa forte e sintonizada com as novas exigências e necessidades da sociedade contemporânea" (KUNSCH, 2016, p. 180).

Kunsch (2016) compreende as organizações para além de meras unidades econômicas, tratando-as como unidades sociais em um contexto mais amplo e destacando sua importância para o desenvolvimento econômico e socioambiental em níveis local e global. Nesse cenário, a comunicação integrada seria "um fator estratégico para o desenvolvimento organizacional na sociedade globalizada" (KUNSCH, 2016, p. 179) em múltiplas perspectivas (econômica, social e ambiental).

Em estudo sobre a comunicação para a sustentabilidade em organizações do terceiro setor, Ulsen $(2018$, p. 42) reforça esse vínculo entre comunicação integrada e desenvolvimento: "A visão integrada compreende a participação da comunicação na gestão estratégica, no desenvolvimento econômico, social e ambiental da organização". A escolha da comunicação integrada para os estudos sobre comunicação em negócios sociais é justificada também por incluir, em sua abordagem da comunicação organizacional, uma dimensão socioambiental.

Isso posto, é por essas quatro formas de comunicação - a institucional, a mercadológica, a interna e a administrativa - que as organizações irão interagir com os seus públicos e com a sociedade em geral (KUNSCH, 2016). No caso dos negócios sociais, essa interação se dará com atores do ecossistema e de fora dele, em dimensões diversas, ou seja, de natureza institucional, mercadológica, interna ou administrativa, e expressa por meio de técnicas, práticas e instrumentos comunicacionais.

\subsubsection{Comunicação administrativa}

A comunicação administrativa é aquela que "se processa dentro da organização, no âmbito das funções administrativas; é a que permite viabilizar todo o sistema organizacional, por meio de uma confluência de fluxos e redes" (KUNSCH, 2016, p. 152). Ressaltamos, na definição da autora, o entendimento da organização enquanto sistema aberto, em que a comunicação irá permear todo o processo de entradas (inputs), transformações (throughputs) e saídas (outputs). 
Em Kunsch (2016), a comunicação administrativa difere-se da comunicação interna, estando relacionada com fluxos, níveis e redes formal e informal de comunicação. Para outros autores, contudo, a comunicação interna engloba todo o processo comunicativo entre pessoas e grupos, incluindo-se a própria comunicação administrativa, com seus fluxos informativos, redes formais e informais e canais de comunicação (MARCHIORI, 2006, apud MEDRANO, 2007).

Enquanto sistema aberto, Sabbatini (2010) ressalta a importância de ampliar alianças estratégicas - fora da estrutura hierarquizada do negócio - a fim articular recursos produtivos e tecnológicos para a pesquisa e desenvolvimento de novos produtos e serviços. Para a autora, "as empresas não conseguem mais reunir individualmente a capacitação tecnológica e os ativos necessários para promover a integração vertical" (SABBATINI, 2010, p. 68), e o intercâmbio de informações com parceiros estratégicos ajudaria a ampliar a rentabilidade e a manter os índices de inovação. Os negócios sociais com foco em inovação social têm a oportunidade, neste cenário, de desenvolver alianças com negócios tradicionais, impactar sua linha produtiva e oferecer vantagens competitivas mais sustentáveis para produtos e serviços de grandes empresas.

Ainda sobre os negócios sociais, cabe especial atenção das aceleradoras à comunicação administrativa nos seus estágios iniciais - que correspondem às fases de estruturação do modelo de negócios, refino e validação da ideia e prototipagem do produto e/ou serviço. É quando se coloca à prova a tese de mudança do negócio, na qual o empreendedor apresenta as suas hipóteses de transformação de uma dada realidade social: "Uma tese de mudança é um proposição convincente de como os insumos do empreendimento irão gerar resultados no curto prazo (outputs) e no longo prazo (outcomes)" (SOCIAL ENTERPRISE KNOWLEDGE NETWORK, 2006, p. 27). A comunicação administrativa poderá desempenhar função importante para tornar esse processo mais eficiente e eficaz, o que trará melhores resultados ao negócio do ponto de vista econômico e dos resultados sociais alcançados.

\subsubsection{Comunicação interna}

A comunicação interna diz respeito à interação entre organização e seus funcionários, o que permite que os colaboradores "sejam bem-informados e a organização antecipe respostas para as suas necessidades e expectativas. Isso ajudará a mediar os conflitos e a buscar soluções preventivas" (KUNSCH, 2016, p. 159). A autora explica 
que, até a redemocratização do país, os investimentos em comunicação interna eram mínimos (KUNSCH, 2016). Depois da mudança de regime, essa subárea começou a ser valorizada em processos de gestão participativa, com maior ênfase no diálogo aberto com os funcionários. Contudo, observamos, a partir de estudos empíricos da área, que a comunicação interna das organizações, ainda que afirme querer o diálogo com os funcionários, segue presa a canais formais de comunicação constituídos a fim de eliminar ruídos e atender a uma lógica de produção (VILAÇA, 2012).

Estudo recente sobre a comunicação interna das empresas brasileiras mostra que entre as tendências da área está o fortalecimento da comunicação face a face, com ênfase no trabalho com lideranças e no uso de canais digitais para apoiar estratégias de comunicação com os funcionários (QUER..., 2019). Entre as fragilidades da comunicação interna está a dificuldade de mensurar seus resultados atrelados aos objetivos organizacionais, sendo necessário assumir uma função mais estratégica no negócio.

Kunsch (2016) ressalta ainda a importância de uma política de comunicação interna que mostre coerência entre discurso e práticas organizacionais: "A qualidade da comunicação interna passa pela disposição da direção em abrir informações, pela autenticidade, usando a verdade como princípio" (KUNSCH, 2016, p. 160). Sabbatini (2007, p. 5) vai além e afirma que o relacionamento transparente com o público interno é de fundamental importância para a efetivação de políticas de comunicação integrada: "É preciso que a democracia na comunicação interna e a participação dos funcionários passe a vigorar com naturalidade na empresa, ou seja, que faça parte da sua essência e do processo de gestão".

Segundo Smith, Gonin e Besharov (2013), o empreendedor social tem que ser capaz de gerenciar demandas múltiplas e geralmente conflitantes originadas pelo compromisso com a missão social e os riscos à sustentabilidade financeira do negócio. Funcionários do negócio social podem questionar, por exemplo, se o negócio está mais alinhado a aspectos financeiros ou à sua missão social. Os autores defendem, para isso, a criação de estruturas internas que tanto diferenciem quanto integrem as lógicas econômicas e sociais do negócio, criando papéis distintos para as gerências.

Além disso, um negócio social precisa lidar no seu dia a dia com inúmeras tensões internas: a questão da contratação e gestão de pessoas, por exemplo, tem o desafio de atrair profissionais ligados tanto à missão social quanto à sustentabilidade financeira do negócio, o que provoca tensões entre os funcionários; no caso de negócios inclusivos, 
há ainda o desafio de ter pessoas em condição de vulnerabilidade social ou minorias ligadas a posições estratégicas do empreendimento, para além de uma política de cotas sociais, tradicionalmente ligadas a cargos subalternos.

Diante de tais particularidades, uma política de comunicação interna sólida, participativa e coerente com os objetivos organizacionais contribuirá substancialmente para os negócios sociais.

\subsubsection{Comunicação mercadológica}

Vinculada diretamente ao marketing, a comunicação mercadológica corresponde a "toda a produção comunicativa em torno dos objetivos mercadológicos, tendo em vista a divulgação publicitária dos produtos ou serviços de uma empresa" (KUNSCH, 2016, p. 162). Trata-se de uma área que precisa ser constantemente abastecida por pesquisas de mercado, com o objetivo de promover relações comerciais que envolvem a trocas de produtos e serviços entre um produtor, normalmente, uma empresa, e consumidor, podendo ser uma pessoa física ou organização.

Por um lado, Smith, Gonin e Besharov (2013, p. 29, tradução nossa) acreditam que "a missão social da organização contribui para o seu sucesso comercial, servindo como uma ferramenta de marketing com os clientes em uma indústria particularmente competitiva" ${ }^{26}$. Por outro, compreender quem é o cliente dos negócios sociais será decisivo para uma comunicação mercadológica eficiente.

Cada vez mais exigentes, os consumidores da contemporaneidade (e os próprios empreendedores sociais) inserem-se em um contexto de maior conscientização quanto aos impactos da ação das empresas no meio ambiente e da sua efetiva contribuição ao desenvolvimento econômico e social, cobrando das organizações "responsabilidade social, atitudes transparentes, comportamentos éticos" (KUNSCH, 2007a, p. 43). Para Kunsch (2007a), as ações isoladas de comunicação e marketing focadas em produtos e serviços são insuficientes para fazer frente aos novos mercados e para se relacionar com os públicos; por isso, a comunicação institucional e a comunicação mercadológica devem ser trabalhadas de forma articulada pela organização.

A comunicação mercadológica de um negócio social passa pela maior conscientização socioambiental de clientes (incluindo os negócios tradicionais e

\footnotetext{
${ }^{26}$ No original: "the organization's social mission contributes to its commercial success, by serving as a marketing tool with clients in a particularly competitive industry".
} 
consumidores da base da pirâmide) e mudança de comportamentos e hábitos, fazendo-os optar por produtos e serviços que gerem benefícios sociais. Para isso, Porter e Kramer (2011, p. 9, tradução nossa) defendem que o marketing deve ir "além da persuasão e da criação de demanda para o estudo de necessidades humanas mais profundas e como atender a grupos de clientes não tradicionais" 27 .

Neste contexto começam a surgir novos métodos de captação de recursos entre os negócios sociais, apoiados em estratégias de marketing de causas (em inglês, causerelated marketing) em grandes empresas (COMINI; FISCHER, [2017]). O marketing de causa está ligado a ações de impacto prático em projetos, causas e iniciativas de cunho social, por exemplo, a doação de parte da renda obtida com a venda de um produto ou serviço para uma causa social. Em 2019, a Yunus Negócios Sociais Brasil lançou a Yunus Corporate, área da organização específica para lidar com grandes empresas em projetos de inovação social. Dois anos antes, a Yunus assessorou o lançamento do projeto Ama, da Ambev, que reverte $100 \%$ do lucro da venda da água mineral para iniciativas em regiões que sofrem com a seca (OLIVEIRA, 2019).

\subsubsection{Comunicação institucional}

A comunicação institucional explicita o lado público das organizações, auxiliando a difundir informações sobre a missão, a visão e os valores do negócio (KUNSCH, 2016). É essencial para a construção de uma imagem organizacional forte e positiva para os seus públicos: "Divulgar a missão da instituição, transmitir a função da empresa e dar ênfase à contribuição da organização para a sociedade são as três principais pretensões da comunicação institucional” (FELIZOLA et al., 2009, p. 6).

Parte-se do princípio de que a organização é uma coletividade inserida em um ambiente aberto e orgânico, com o qual mantém constantes trocas de sentidos e significados, provendo os públicos com informações sobre si:

Para a empresa já não é suficiente "saber fazer", faz falta sobretudo "fazer saber", ou seja, fazer conhecer a própria capacidade, ressaltá-la frente à competência, fazendo visível sua qualidade e seu valor. Nesta ótica, a empresa se comunica para conseguir credibilidade, confiança, fidelidade e transmitir seriedade e confiabilidade (MEDRANO, 2007, p. 47).

\footnotetext{
${ }^{27}$ No original: "marketing courses will have to move beyond persuasion and demand creation to the study of deeper human needs and how to serve nontraditional customer groups".
} 
Nesta perspectiva, a comunicação institucional sofreu grandes transformações devido a dois fenômenos contemporâneos: a maior conscientização dos públicos quanto ao papel das organizações no desenvolvimento econômico e social, como citado anteriormente, e o avanço das tecnologias da informação, que aproximaram pessoas e organizações. Neste cenário, ser uma empresa transparente e responsável vai além de fornecer informações financeiras e balanços contábeis: "Tudo isto implicará a necessidade de se planejar, pensar e administrar estrategicamente a comunicação organizacional com todos os públicos e a opinião pública" (KUNSCH, 2007a, p. 42). Ou seja, para que sejam eficazes, as estratégias de comunicação institucional precisam promover a interação entre organização e públicos.

Kunsch (2016) aponta alguns dos componentes da comunicação institucional integrada: relações públicas (que atua no posicionamento da empresa em relação aos públicos), jornalismo empresarial (produção de conteúdo para publicações empresariais), assessoria de imprensa (relacionamento com jornalistas e monitoramento da imagem na imprensa), editoração multimídia (design e web design de produtos comunicacionais), imagem corporativa, identidade corporativa, propaganda institucional, marketing social (promoção de ideias, causas e programas sociais) e marketing cultural (promoção e patrocínio da cultura).

O storytelling é exemplo de técnicas de comunicação institucional em negócios sociais que, quando praticadas em âmbito organizacional, visam não somente conquistar e reter a atenção dos públicos, mas também despertar emoções e gerar a confiança no negócio. O storytelling, ou as "narrativas", carrega força simbólica a fim de persuadir e criar reputação favorável às organizações e, para Farias, Penafieri e Miano (2015), pode ter uso estratégico no resgate da memória institucional, no incentivo à gestão do conhecimento e inovação e na comunicação interna, para valorizar as pessoas e promover a humanização nas organizações. "As relações públicas têm no storytelling um grande aliado para tornar o que é intangível em uma organização passível de experimentação" (FARIAS; PENAFIERI; MIANO, 2015, p. 5305), tornando possível vivenciar aspectos da cultura organizacional.

Assim, os negócios sociais podem, em nossa análise, se valer de técnicas de storytelling no desenvolvimento de campanhas para seus públicos e na comunicação dos seus resultados sociais. Ao contar a história de empreendedores, geralmente repleta de elementos com os quais qualquer investidor social pode se identificar, o empreendedor social pode mostrar como o seu negócio faz a diferença na vida das pessoas. 
Outro exemplo ligado ao planejamento tático e operacional da comunicação institucional é a participação em eventos significativos do segmento em que atua, o que pode, no âmbito de um planejamento mais amplo, se tornar estratégia significativa para os negócios sociais ganharem mais visibilidade, captarem novos investidores e posicionarem-se, em médio prazo, como referência no setor, por exemplo, em entrevistas para a imprensa.

Ao analisar a gestão de negócios sociais, Smith, Gonin e Besharov (2013) identificam tensões ligadas à identidade organizacional, o que chamam de "tensões de pertencimento". Segundo os autores, as tensões e contradições da identidade do negócio social - que costumam ter identidades divergentes quanto aos aspectos sociais e econômicos do negócio - podem emergir no público interno, nos investidores, em fundações, doadores, clientes, fornecedores e na própria opinião pública.

Outra particularidade da comunicação institucional em negócios sociais é a possível presença de múltiplas identidades organizacionais (SMITH; GONIN; BESHAROV, 2013), o que pode provocar conflitos com os públicos, sobretudo o público interno, já que há uma tendência entre os membros da organização de focar em uma ou outra dessas identidades. Além disso, organizações com identidades múltiplas podem ter mais dificuldade em ser compreendidas pelos públicos, o que deve ser levado em consideração pelas estratégias de comunicação institucional. Por outro lado, a missão social e os resultados econômicos podem se reforçar mutuamente, permitindo que o negócio seja bem-sucedido em ambas as frentes (SMITH; GONIN; BESHAROV, 2013).

Outra particularidade é a necessidade de uma comunicação que estimule o próprio ecossistema de negócios sociais no mercado produtivo e auxilie no reconhecimento da sua importância na solução de problemas sociais. Nesse sentido, uma tendência recente é o fortalecimento da identidade do ecossistema, com maior exposição na mídia e parcerias com grandes empresas, incentivando o surgimento e crescimento dos negócios sociais (O RETRATO..., 2019).

Por fim, vale destacar que a comunicação integrada pressupõe uma visão sistêmica das organizações, formada por partes inter-relacionadas. Kunsch (2007a, p. 48), sem defender a compartimentação da área, mas somente para "tornar os conceitos muito mais didáticos e compreensíveis", propõe um diagrama da comunicação integrada (Figura 8).

Pereira (2017) compreende a comunicação integrada como um ponto de intersecção entre a perspectiva da comunicação organizacional e de relações públicas, 
hoje adotado por grande parte da comunidade acadêmica da área. Em paralelo, o modelo também é empregado por um número crescente de agências na área de comunicação, "agregando valor a seus serviços, na medida em que se sentem capacitadas para gerarem soluções rápidas e eficientes, tornando-se um diferencial competitivo no seu mercado de atuação" (PALMERSTON et al., 2004, p. 4-5). Sabbatini (2007) aponta, contudo, a dificuldade de se alinhar na prática os diversos interesses das dimensões administrativa, interna, mercadológica e institucional da comunicação, superando os fluxos e redes formais e tradicionais em prol de um sistema integrado, menos burocrático e mais flexível e democrático, alinhado aos objetivos da organização.

Figura 8 - Comunicação integrada

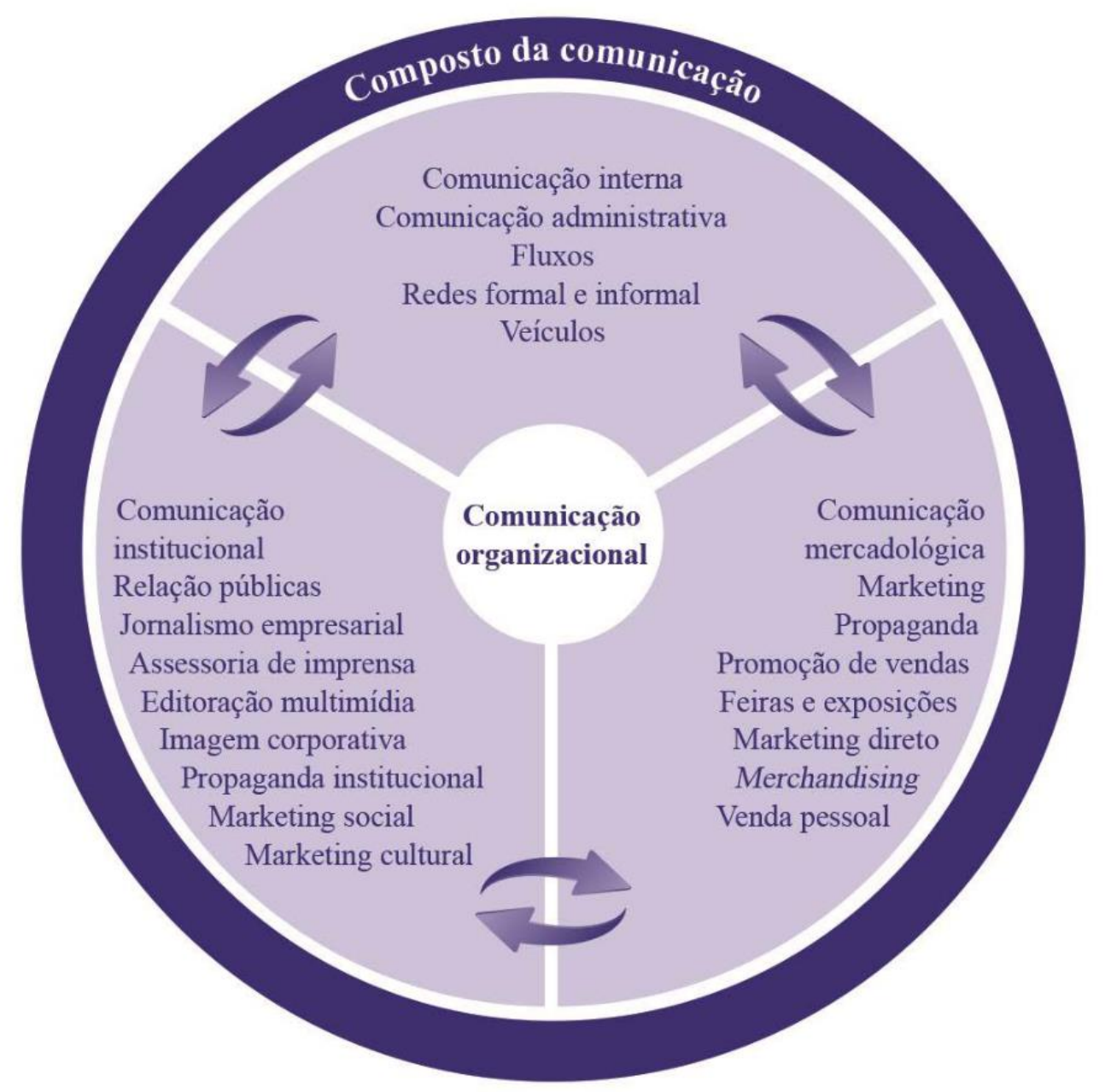

Fonte: Kunsch (2016, p. 151).

Refletir sobre a comunicação dos negócios sociais à luz da filosofia da comunicação integrada implica dar conta de dimensões múltiplas do fenômeno comunicacional. Quando aplicada aos negócios sociais, de natureza híbrida, essa filosofia 
deve incluir elementos inerentes a tais modelos organizacionais. A comunicação integrada deve ter em vista, por exemplo, as tensões provocadas pelas contradições que emergem da justaposição entre a missão social e os objetivos financeiros. A missão social do negócio é central e deverá ser contemplada em todo o mix da comunicação administrativa, interna, mercadológica e institucional - e em seu planejamento estratégico global.

\subsection{Políticas e estratégias na gestão da comunicação dos negócios sociais}

Tendo estabelecido o conceito de comunicação integrada, macrotendências e paralelos com os negócios sociais, dedicamo-nos a seguir a tecer algumas considerações sobre a prática da comunicação integrada em seus aspectos estratégico, tático e operacional.

Em primeiro lugar, devemos destacar a necessidade, verificada junto aos próprios empreendedores sociais, de uma maior atuação da comunicação neste segmento. A segunda edição do Mapa de negócios de impacto social + ambiental indica que os empreendedores sociais pedem ajuda em questões relacionadas à "comunicação" do negócio em 19\% dos casos estudados, ficando atrás apenas de "dinheiro", com $48 \%$ das menções, e "mentoria", com 22\% (O RETRATO..., 2019). "Parcerias e networking" (19\%) e "Vendas" (11\%) foram outros pedidos de ajuda citados pelos negócios sociais que poderão se beneficiar diretamente de políticas e estratégias de comunicação integrada.

Em consulta a 56 empreendedores sociais, a ESPM Social (2019) buscou identificar o uso de estratégias de marketing e dos processos de comunicação em negócios sociais. A ampla maioria dos negócios consultados $(78,6 \%)$ compreende que a comunicação e o marketing são significativos para esse tipo de empreendimento. Outro dado importante é que, do total de negócios que responderam à pesquisa, 66,7\% receberam apoio de aceleradora sobre assuntos relacionados à comunicação e ao marketing (ESPM SOCIAL, 2019). A "nota" atribuída ao apoio da aceleradora ao negócio, contudo, foi baixa: 5,7.

Os dados do estudo referido apontam ainda uma realidade social em mudança, em que os mercados estão mais acirrados e há novos perfis de públicos (ESPM SOCIAL, 2019). Nesse cenário, a comunicação fragmentada já não atende às necessidades das organizações contemporâneas, que exigem “criatividade, atenção redobrada aos públicos 
e baixo custo nas ações comunicativas" (PALMERSTON et al., 2004, p. 2). Isso posto, a comunicação integrada

passa a ser uma arma estratégica para a sobrevivência e o desempenho de uma organização em uma realidade complexa e que se altera de forma muito rápida. Hoje em dia, não é possível mais pensar, por exemplo, em realizar uma brilhante assessoria de imprensa, criar campanhas retumbantes ou produzir peças publicitárias impactantes de forma isolada, sem o envolvimento de todas as subáreas da comunicação organizacional (KUNSCH, 1997, p. 149).

Diagnosticando as realidades da comunicação nas empresas, Kunsch (2006) observa quatro realidades distintas (para fins deste estudo, buscamos, no Capítulo 5, avaliar a realidade da comunicação do Quintessa e dos negócios sociais consultados). São elas:

1) organizações em que a comunicação tem valor estratégico, com investimentos regulares em pessoas e profissionais da área;

2) organizações em que a comunicação tem valor tático e técnico, com fins de divulgação, mas sem estratégias e diretrizes claras;

3) organizações em que a comunicação é reativa e improvisada;

4) organizações em que a comunicação é espontânea, sem qualquer atenção específica a ela.

Para compreender a realidade comunicacional das organizações, a etapa de diagnóstico é fundamental. Sabbatini (2007) identifica 11 passos para essa etapa, que contemplam aspectos do planejamento estratégico de comunicação do negócio, a clareza e transparência da comunicação com os públicos, o perfil dos profissionais da área, como os resultados são mensurados, os mecanismos de participação dos funcionários e as características das estruturas e fluxos comunicacionais, a fim de superar uma ideia de gestão mecanicista.

No caso dos negócios sociais, podem ser analisados: a presença de uma área ou de profissionais da área de comunicação, a adoção de serviços de comunicação terceirizados, se há instrumentos de comunicação, se a comunicação tem um planejamento próprio, se há clareza quanto à definição de públicos e as estratégias de comunicação dirigidas a eles, a regularidade nos investimentos em comunicação, entre outros fatores.

A comunicação integrada também precisa estar respaldada por um planejamento estratégico, que deverá "contemplar análises sociais, políticas, mercadológicas, econômicas e culturais e fomentar o pensar crítico e a integração constante entre as 
diversas áreas da empresa" (SABBATINI, 2007, p. 8). O planejamento global da comunicação integrada - que direcione as ações da área de forma eficiente - pode minimizar um possível complicador na gestão comunicacional em termos práticos que são as diferenças entre os instrumentos utilizados.

Para Palmerston et al. (2004), a comunicação integrada é uma tendência verificada, sobretudo, em médias e grandes organizações, uma vez que pequenas empresas não costumam contar com infraestrutura e equipes diversificadas na área. Em nossa visão, contudo, a comunicação integrada não é entendida, em suas diretrizes principais, pela presença de profissionais da área com formações diversificadas, mas por uma gama de técnicas, funções e práticas de comunicação em diferentes frentes de atuação, articuladas por uma política global e em consonância com os objetivos organizacionais.

Nesse sentido, a noção de "árvore da comunicação" (Figura 9), proposta por França e Ferrari (2008), resume de forma didática a perspectiva de política global de comunicação adotada neste trabalho.

Figura 9 - Árvore da comunicação

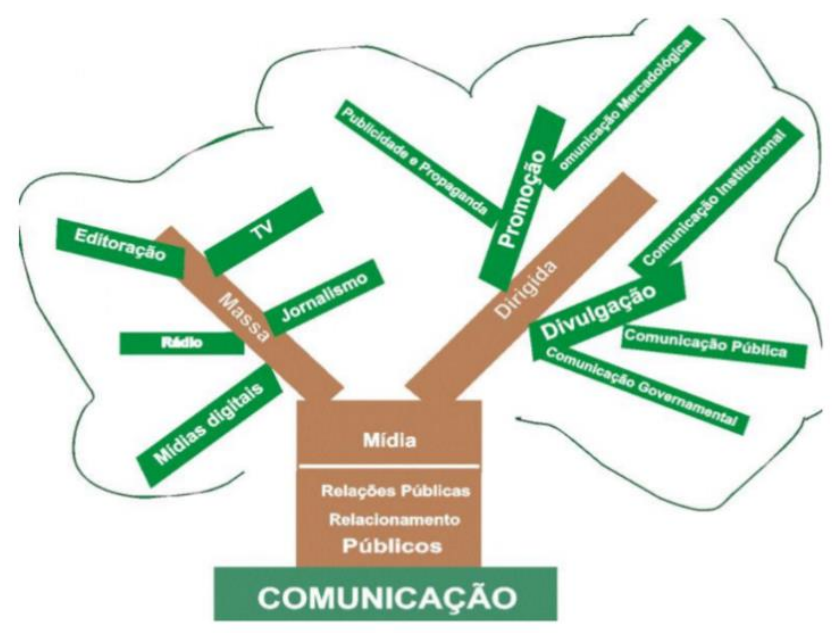

Fonte: França e Ferrari (2008, p. 5).

A comunicação é tratada como uma grande área, em que se estabelecem as relações humanas de modo contínuo, e suas ramificações ou subáreas e gêneros específicos são classificados e formam o composto da comunicação. Nessa perspectiva, os públicos são o objeto primeiro da comunicação de uma empresa (FRANÇA; FERRARI, 2008). 
Para Oliveira e Paula (2006), compõem uma comunicação estratégica: a) o tratamento processual da comunicação, compreendida numa visão ampla e integrada; b) a inserção na cadeia decisória, ou seja, a comunicação é um requisito para a análise e o gerenciamento de situações e cenários e seus efeitos na reputação da organização e relacionamento com os atores sociais; c) a gestão dos relacionamentos com os atores sociais, ou seja, o planejamento e a condução sistemática e monitorada das interações com os públicos da organização; d) o uso sistemático do planejamento, que contempla a "formulação de estratégias de posicionamento e de relacionamento da organização com o ambiente, buscando garantir a articulação entre os fluxos informacionais e relacionais" (OLIVEIRA; PAULA, 2006, p. 9); e, por fim, e) a identificação de expectativas e o monitoramento de desempenho e da contribuição para os resultados da organização.

O elevado número de instrumentos de comunicação disponíveis requer uma escolha consciente e bem pensada por meio de um processo de planejamento e gestão estratégicos, assim como a coordenação de uma equipe de trabalho na área de comunicação formada por profissionais com diferentes habilidades e competências. Com o crescimento da comunicação digital e o surgimento de novos instrumentos, relações públicas, jornalistas e publicitários precisam atuar de forma conjunta com profissionais de outras áreas, tais como programadores, analistas de sistemas, gestores da informação e programadores gráficos (CASALI, 2002).

Em estudo sobre o impacto das tecnologias da informação sobre a comunicação integrada, Casali (2002) aponta a necessidade de que cada veículo de comunicação ofereça um benefício singular, com grandes possibilidades de interação com os públicos. Os conteúdos não devem ser repetidos nos diferentes canais; em vez disso, "os diversos meios de comunicação são utilizados para compor um cenário onde a mensagem final será formada apenas na cognição do receptor" (CASALI, 2002, p. 7). Não se trata, portanto, de uma centralização da comunicação e sim de um esforço coordenado da organização com os diferentes instrumentos e técnicas comunicacionais.

Na prática, as ações de comunicação devem ser, portanto, planejadas e avaliadas em termos de integração e complementaridade entre si, numa perspectiva própria da comunicação integrada.

Comunicação integrada pressupõe a utilização comum de imagens, informações e mensagens em várias frentes midiáticas, quando estrategicamente pertinentes, bem como a divulgação de determinada ação e de seus resultados utilizando outras ações de comunicação (exemplo: um filme publicitário utilizando imagens captadas em um evento social apoiado pela 
empresa etc.), otimizando e complementando o processo como um todo (YANAZE, FREIRE; SENISE, 2013, p. 176).

Na contemporaneidade, Casali (2002) defende ainda uma comunicação integrada que pretenda coordenar as mensagens com o máximo de impacto nos públicos. "Surge a necessidade da criação de mídias alternativas e independentes, bem como a criação de uma comunicação segmentada, quase única, se possível individualizada, personalizada" (CASALI, 2002, p. 9), cujo planejamento deve contemplar o conceito a ser compartilhado, públicos, abrangência do veículo, repetição e coordenação das mensagens.

Em estudo sobre comunicação e governança corporativa, Smith (2015) conclui que as ações de engajamento (e, portanto, de comunicação) ainda são definidas conforme a agenda do gestor, em função das possíveis ameaças e oportunidades para o negócio. Apesar de se classificar como comunicação estratégica, trata-se de uma política e filosofia comunicacional que não objetiva o entendimento com os públicos, servindo somente aos interesses de uma das partes. A autora propõe desenhos de colaboração mais propensos à "tomada de decisão e escolhas coletivas que gerem mútuos benefícios a todos os participantes" (SMITH, 2015, p. 140) - perspectiva que, em nossa análise, também contribuiria para os resultados dos negócios sociais.

Para isso, o desafio é conceber um planejamento de comunicação inovador e multidimensional que dê visibilidade aos produtos e à causa social ligada ao negócio e, ao mesmo tempo, leve em conta as restrições orçamentárias dos negócios sociais em estágios iniciais. O uso de canais alternativos de comunicação no ecossistema de negócios sociais é recomendado para dialogar com pessoas de menor renda e buscar formas de dar capilaridade para o negócio (PROGRAMA DAS NAÇÕES UNIDAS PARA O DESENVOLVIMENTO; FUNDAÇÃO DOM CABRAL, 2015).

Os negócios sociais - que se afastam dos modelos de empresas tradicionais e também se distinguem das organizações filantrópicas típicas - podem, em nossa análise, se beneficiar de políticas e estratégias de comunicação em todas as suas fases, da ideação à expansão e escalada do empreendimento. Para isso, as estratégias e políticas de comunicação dos negócios sociais deverão estar atreladas aos objetivos de negócio (social e financeiro), com ênfase em processos de interação participativos e democráticos, com benefícios mútuos aos negócios e aos seus públicos, sobretudo as comunidades diretamente impactadas pela tese de mudança. 


\subsection{Classificação de públicos e o ecossistema de negócios sociais}

Elemento central da função e atividade de relações públicas, a boa gestão do relacionamento com os públicos das organizações também é contemplada em nossa pesquisa. A escolha de adicionar esta reflexão em nossa análise se justifica pelo entendimento de que "no empreendedorismo social os desafios socioambientais demandam um olhar sistêmico, que envolve sensibilização, diálogo, mobilização e relacionamento com grupos de interesses diversos" (OLIVEIRA; NADER, 2017, p. 49).

"Públicos" são grupos ou setores relacionados com a organização de forma permanente ou não. França (2012), ao conceituar o termo de maneira lógica, explica que essa concepção deve ir além de um agrupamento de pessoas e avaliar as especificidades e os níveis de interesse dos públicos nas relações com a organização. Expressão comum, a noção de "público em geral" seria contraditória, uma vez que "um público é sempre um grupo especializado e cujos membros têm interesse específico nas atividades e comportamentos das organizações" (GRUNIG; FERRARI; FRANÇA, 2009, p. 82). Andrade (1993) entende que públicos são grupos formados por pessoas adultas, com opiniões múltiplas, em busca de uma atitude comum - uma expressão da coletividade para um problema ou controvérsia compartilhada por todos. Segundo o autor, "a presença de uma controvérsia, a oportunidade de discussão e o aparecimento de uma decisão ou opinião coletivas" são características do que se pode classificar como público (ANDRADE, 1993, p. 13-14).

Também é comum ver o conceito de público quase como sinônimo de stakeholder. Kunsch (2007a, p. 45), porém, aponta diferenças entre os dois termos: para a autora, o termo "stakeholders" "não pode ser usado para qualquer tipo de público.

Diríamos que ele se refere somente a públicos 'realmente estratégicos"”. Os stakeholders são pessoas ou grupos que estão ligados à organização e mantêm com ela uma relação lógica de legitimidade e/ou poder (FRANÇA, 2012). Pela teoria dos stakeholders, "consideram-se públicos aqueles que $\mathrm{t}[\hat{\mathrm{e}}] \mathrm{m}$ parceria financeira ou comprometimento estável (stake) com a organização" (FRANÇA, 2012, p. 45) e, por isso, são considerados importantes sustentadores (holders) de negócios.

O mapeamento de públicos é uma atividade básica das relações públicas a fim de obter a maior eficácia e assertividade da comunicação organizacional. Andrade (1993) foi um dos primeiros a propor um mapeamento de públicos, classificando-os como internos, externos ou mistos. Em justaposição à comunicação integrada e ressalvadas as 
suas diferenças e especificidades, a comunicação administrativa e a interna priorizariam os públicos internos, enquanto a comunicação mercadológica e a institucional destinamse, sobretudo, aos públicos externos (SCROFERNEKER, 2006).

Anos mais tarde, observou-se que tal classificação dos públicos acabava por provocar incertezas quanto ao papel específico de cada público em relação à organização, o que, consequentemente, prejudicava a definição de programas de relacionamento e ações de comunicação. Os públicos "não podem ser considerados sob o critério genérico de internos, externos, mistos, mas do ponto de vista global da sua relação direta com a organização, merecendo cada um deles tratamento diferenciado em termos de transmissão e recepção de mensagens" (FRANÇA; FERRARI, 2008, p. 6).

Kunsch (2007a, p. 45) reforça a necessidade de uma nova classificação de públicos diante das mudanças contemporâneas trazidas pelas tecnologias da informação: "Na era digital o conceito tradicional de públicos dimensionados por espaço geográfico, nas categorias de interno, misto e externo não dá conta de acompanhar a dinâmica dos dias de hoje". Para a autora, o relacionamento com os públicos foi alterado e hoje ultrapassa fronteiras geográficas, "envolvendo as redes sociais criadas no ciberespaço, que também têm o poder de provocar mudanças comportamentais" (KUNSCH, 2007a, p. 47).

Com o avanço dos estudos acerca da diversidade de públicos, França (2012) apresenta uma classificação para a qual utiliza três critérios considerados lógicos, aplicáveis à análise de qualquer tipo de relação organizacional, e que permitem compreender melhor os públicos. São eles:

a) o grau de dependência jurídica e situacional da organização em relação aos seus públicos;

b) o maior ou menor grau de participação dos públicos nos negócios da empresa; e

c) o grau de interferência que determinados públicos podem exercer sobre a organização e seus negócios.

Dessa forma, França (2012) classifica os públicos em organizados (divididos ainda em essenciais e não essenciais) e não organizados. Os públicos essenciais são aqueles ligados à missão e aos objetivos da organização, e são classificados em constitutivos, ou seja, públicos dos quais depende a existência da organização, e não 
constitutivos ou de sustentação, que atuam diretamente na viabilização da organização no ambiente em que atua. Os públicos de sustentação podem ser primários ou secundários.

Os públicos não essenciais são "redes de interesse específico, pelo grau de maior ou menor participação nas atividades da organização. São considerados não essenciais, pois não participam das atividades-fim, apenas das atividades-meio" (FRANÇA, 2012, p. 80). São divididos em: redes de consultoria e serviços promocionais, redes de interesses associativos e organizados, redes sindicais e redes setoriais da comunidade. Por fim, as redes de interferência são formadas por públicos que de alguma forma influenciam o andamento do negócio, e são quatro: redes de concorrentes, redes de comunicação de massa, redes de ativistas e redes ideológicas. Tendo estes critérios e classificações em vista, o mapeamento de públicos deve contemplar: os tipos de públicos com os quais a organização interage; os objetivos da organização e expectativas de relacionamento; o nível de dependência; as expectativas da organização; e as expectativas dos públicos (FRANÇA, 2010).

Grunig e Hunt (1984) propõem uma teoria situacional pela qual os públicos são identificados como grupos de pessoas que: 1) enfrentam um problema em comum;2) reconhecem a existência do problema; e 3) se organizam para fazer algo em relação ao problema. Contempladas as três condições, os autores propõem três tipos de públicos: os públicos ativos são organizados para discutir e reagir ao problema; os públicos latentes enfrentam o problema oriundo da organização, mas não o detectam; já os públicos conscientes, ao contrário, são aqueles que detectam o problema. Por fim, o não público é aquele que não contempla nenhuma das três condições e, portanto, não influencia a organização. Se, por um lado, a classificação proposta pelos autores pode provocar uma postura reativa das organizações, por outro, a distinção de públicos pela sua relação diante de um problema pode contribuir para um cenário de arranjos e rearranjos do ecossistema de negócios sociais, em que os públicos são centrados em um problema social, e portanto coletivo de toda a sociedade.

A identificação dos públicos é seguida de uma pesquisa dos problemas e das questões que podem vir a afetar possíveis estratégias de relacionamento (GRUNIG, 2005). É quando a organização parte para o desenvolvimento de políticas de relacionamento com os públicos segundo os princípios da comunicação integrada, ou seja, caracterizando-se por sua natureza global, trabalhando simultaneamente "as relações com a sociedade [...] em sinergia com o planejamento estratégico da organização" (FRANÇA; FERRARI, 2008, p. 7). 
Na visão do sociólogo Lucien Matrat, decisões, comportamentos, julgamentos e opiniões dos públicos podem influenciar o desenvolvimento de uma organização (XIFRA TRIADÚ, 2006). O pesquisador francês classifica os públicos em quatro categorias: de decisão, consulta, comportamento e opinião. Os públicos de decisão são aqueles dos quais a organização depende para o exercício de suas atividades, por exemplo, os acionistas; os públicos de consulta são aqueles que devem ser sondados pela organização antes de agir ou tomar decisões estratégicas, como entidades de classe; os públicos de comportamento são aqueles que podem estimular ou prejudicar a organização pela sua atuação, caso de funcionários e clientes; por fim, os públicos de opinião influenciam a organização ao manifestar seu julgamento ou ponto de vista, por exemplo, os formadores de opinião e a mídia (FRANÇA, 2012).

Entre as funções essenciais do profissional de relações públicas está classificar e mapear os relacionamentos de uma organização. Também é responsável por elaborar diretrizes, selecionar instrumentos de comunicação e criar as mensagens adequadas a cada público (FRANÇA; FERARRI, 2008). Um programa de relações públicas deve contemplar, para isso, objetivos em curto e longo prazos e respectivos indicadores da qualidade de relacionamento; planejamento e implementação de um programa de comunicação com os públicos; e, por fim, sua avaliação, a fim de verificar seus resultados em relação aos objetivos previamente estabelecidos (GRUNIG, 2005).

Uma boa gestão do relacionamento com os públicos implica inúmeras vantagens à organização - por exemplo, aumentar o valor do negócio, promover melhor a sua imagem e reputação, gerar mídia espontânea, possivelmente reduzir custos e melhorar a produtividade e competitividade, além de contribuir para atração de investidores e fidelização de clientes. Segundo Bueno (2002, p. 86), "não resta dúvida de que o processo de segmentação dos públicos acarreta mudanças formidáveis na comunicação empresarial, com a implementação de canais [...] para atender a demandas informativas localizadas".

Sabbatini (2010, p. 108) alerta que, nas empresas, é comum considerar que os públicos sejam "simplesmente meio para que os acionistas alcancem seus objetivos", vinculando-os à cadeia de valor do negócio e à maximização de retorno financeiro. Em oposição a esta perspectiva, Deetz (2017) irá defender a ampliação da participação dos públicos na tomada de decisões e na governança corporativa. Para o autor, a inclusão dos públicos nos processos decisórios "é essencial para o processo de criatividade que pode 
promover o alcance dos interesses econômicos e sociais, em vez da negociação de interesses, uns contra os outros" (DEETZ, 2007, p. 273).

Faz-se assim necessário explorar práticas de comunicação alternativas e colaborativas, centradas no diálogo e na colaboração entre os públicos, a fim de promover um entendimento mais profundo das várias formas organizacionais:

\footnotetext{
Quanto antes as empresas conseguirem inserir os valores sociais na cadeia de decisão, maior será a melhoria na qualidade do produto e do serviço, a eficiência e o desempenho econômico da organização, os benefícios econômicos e sociais para as partes interessadas e o desenvolvimento contínuo da confiança social e a capacidade de tomar decisões juntos (DEETZ, 2017, n. p.).
}

Em novos modelos organizacionais, tal como os negócios sociais híbridos, com múltiplos propósitos, a comunicação deve buscar convergir as demandas do negócio com as demandas dos demais públicos envolvidos, sobretudo aqueles considerados essenciais para a tese de mudança do negócio. Para isso, em complemento à noção de ecossistema de negócios sociais - pela qual a literatura da área e os atores sociais que atuam neste segmento compreendem como as diferentes organizações interagem entre si - pode ser somada a percepção de conceituação e classificação lógica de públicos (FRANÇA, 2012), própria da área de relações públicas.

A conceituação e classificação de públicos permitirá aos negócios sociais, em nossa análise, compreender as especificidades e expectativas dos públicos e gerenciar e priorizar de forma mais estratégica o seu relacionamento com eles para, desse modo, fazer um uso mais eficaz dos diferentes instrumentos de comunicação dirigida. Além disso, a percepção de públicos amplia a noção de stakeholders, expressão recorrente na literatura sobre negócios sociais, podendo fazer emergir, em nossa análise, novas possibilidades de aliança e parcerias estratégicas a fim de ampliar o impacto social dos negócios sociais e obter vantagem competitiva para seus produtos e serviços.

\subsection{Comunicação para a sustentabilidade: uma contribuição para a comunicação dos negócios sociais}

Para fins de análise e reflexão acerca da comunicação nas suas variadas dimensões nos negócios sociais, pretendemos destacar estudos recentes dedicados a discutir as relações entre a sustentabilidade e a comunicação no âmbito das organizações.

Os estudos sobre a comunicação para a sustentabilidade ressaltam, em linhas gerais, a dimensão comunicativa como condição imprescindível para a promoção de 
iniciativas sustentáveis no âmbito das organizações e para maior conscientização dos públicos quanto a causas socioambientais. Os estudos analisados também convergem para a relevância que a comunicação para a sustentabilidade assume na contemporaneidade, nas organizações dos três setores e para a sociedade como um todo. Também apontam os desafios impostos para a promoção de processos comunicativos eficazes na conscientização e engajamento de diferentes segmentos sociais no sentido de incentivar ações concretas de preservação do meio ambiente e combate às injustiças sociais.

A ONU aponta "Relato e Comunicação" como o quinto e último passo para a implementação dos ODS nas organizações (GLOBAL REPORTING INITIATIVE; UNITED NATIONS GLOBAL COMPACT; WORLD BUSINESS COUNCIL FOR SUSTAINABLE DEVELOPMENT, [2015]). O documento Guia dos ODS para as empresas, voltado sobretudo para as grandes corporações e, por sugestão da entidade, passível de ser adaptado por pequenos e médios negócios, destaca, no tópico dedicado à comunicação, indicadores para a elaboração de relatório de sustentabilidade, a fim de manter uma comunicação efetiva e transparente quanto às contribuições dos negócios para o desenvolvimento sustentável. A abordagem dada pelo Guia à comunicação é essencialmente instrumental, centrada em ferramentas diversas para a comunicação da sustentabilidade nas empresas: além do relatório, websites corporativos, canais de mídia social, eventos, rotulagem de produtos e serviços, mercado e publicidade são citados como "algumas das muitas formas efetivas de se comunicar com as partes interessadas em sustentabilidade" (GLOBAL REPORTING INITIATIVE; UNITED NATIONS GLOBAL COMPACT; WORLD BUSINESS COUNCIL FOR SUSTAINABLE DEVELOPMENT, [2015], p. 28).

Cox (2010) identifica duas funções distintas da comunicação para a sustentabilidade: a primeira é de natureza pragmática, ou seja, refere-se a uma comunicação de caráter instrumental, atuando em suporte à solução de problemas ambientais por meio de ações comunicacionais; a segunda é de natureza constitutiva, isto é, auxilia no entendimento sobre o mundo natural, suas demandas, problemas e alternativas de soluções.

O CEBDS destaca a contribuição da comunicação para o entendimento e mobilização dos públicos da organização sobre a sustentabilidade e as ações de responsabilidade social. É função do profissional de comunicação esclarecer conceitos relativos à sustentabilidade, considerados fundamentais na construção de uma consciência global favorável ao desenvolvimento sustentável (CONSELHO 


\section{EMPRESARIAL BRASILEIRO PARA O DESENVOLVIMENTO SUSTENTÁVEL,}

2010). Por esta razão, as áreas de comunicação e sustentabilidade devem estar fortemente interligadas, principalmente nas grandes organizações, em "relação que vai além do suporte operacional, assumindo caráter estratégico" (KUNSCH, 2015, p. 27).

Assim, mais do que práticas desconexas, Kunsch (2009) aponta a importância da comunicação integrada na gestão da sustentabilidade, em que se adote uma visão mais ampla do fenômeno comunicacional e se considerem suas dimensões:

a) humana, com a "abertura de canais dialógicos de fato e que possibilite[m] maior valorização das pessoas" (KUNSCH, 2012, p. 269);

b) estratégica, baseada em planejamento e com vistas a eficácia e geração de resultados organizacionais; e

c) instrumental, esta última predominante nas organizações, com caráter funcional e técnico para a transmissão de informações e viabilização de processos.

Para a autora, a comunicação para a sustentabilidade só será possível em organizações que busquem implementar políticas de transparência para as ações de sustentabilidade, bem como adotem uma filosofia orientada para o "desenvolvimento integrado dos aspectos econômico, social e ambiental” (KUNSCH, 2009, p. 72-73). É fundamental também que a comunicação não seja desvinculada das decisões organizacionais, sejam elas de caráter econômico ou político, ocupando assim "lugar de destaque na estrutura organizacional" (KUNSCH, 2009, p. 71). Dessa forma, a comunicação deixará de ser mera tática e passará a ser considerada área estratégica na gestão da sustentabilidade nas organizações.

Nesse sentido, a sustentabilidade deve ser contemplada em todas as dimensões da comunicação integrada. Segundo Vilaça (2012, p. 267), a comunicação interna da sustentabilidade, por exemplo, não deve ser centrada em "vitórias e sucessos"; ao contrário, deve abrir espaço, na visão da autora, "para a oferta de insumos capazes de serem vistos como impulsionadores para a formação de uma nova consciência" (VILAÇA, 2012, p. 267, grifo da autora) de funcionários e demais públicos.

No âmbito organizacional, o discurso do desenvolvimento sustentável não deve ser apenas retórica, mas se efetivar em práticas e condutas que induzam à reflexão, à deliberação e ao debate, gerando mudanças reais nos comportamentos e valores daqueles que o recebem (VILAÇA, 2012, p. 108).

$\mathrm{Na}$ comunicação institucional, as organizações devem enfatizar os aspectos relacionados à missão, visão e aos valores, promovendo ações de relacionamento, diálogo 
e conscientização de seus públicos. A comunicação mercadológica, por sua vez, deve buscar esclarecer os consumidores, ultrapassando a barreira do consumo e do consumerismo. Para Kunsch (2009, p. 73), a comunicação das organizações não pode se caracterizar apenas como instrumento publicitário, mas "precisa ser expressão de um compromisso público com a sustentabilidade”.

Lourenço e Marchiori (2013) também se dedicam a refletir sobre a comunicação para a sustentabilidade nas organizações, a fim de facilitar relacionamentos, promover processos interacionais e proporcionar um ambiente de entendimento coletivo acerca da sustentabilidade e das práticas de responsabilidade social. Segundo as autoras, para que tais práticas sejam efetivas de fato, a sustentabilidade deve ser constituída como um valor organizacional, mudança que passa necessariamente pela conscientização e mudança de comportamentos dos sujeitos que compõem a organização.

Nesse sentido, a comunicação sustentável "favorece o entendimento da sustentabilidade como um valor, fazendo com que esta ocorra naturalmente no ambiente organizacional" (LOURENÇO; MARCHIORI, 2013, p. 12), o que evidencia, para as autoras, que o sucesso das práticas organizacionais nesta área irá depender do comportamento e da conscientização dos indivíduos sobre a sustentabilidade.

Um melhor entendimento das pessoas sobre sustentabilidade passa, em primeiro lugar, pela própria compreensão da temática e da sua importância para a sociedade, motivo pelo qual alguns autores têm se dedicado à análise e reflexão das práticas discursivas sobre sustentabilidade. É o caso de Baldissera (2009), que ressalta as intenções de uso e apropriação do termo "sustentabilidade" pelas organizações com vistas a ganhar a simpatia da opinião pública, gerar capital simbólico e neutralizar possíveis questionamentos.

Segundo o autor, o "termo sustentabilidade é da qualidade do polissêmico, empregado para designar diferentes ideias e intenções” (BALDISSERA, 2009, p. 37), sendo necessário superar as incertezas quanto ao seu significado para colaborar com uma alfabetização ecológica, tal qual propõe o autor, da sociedade como um todo. O autor afirma ainda que, "de modo geral, acredita-se que a sociedade e suas organizações se encontram distantes de compreender a significação contemplada pela noção de sustentabilidade" (BALDISSERA, 2009, p. 38). Esta perspectiva é reforçada por Bueno (2011) ao apontar que a comunicação pode contribuir para a consolidação do conceito de sustentabilidade, evitando associá-la a ações meramente pontuais ou restringindo-a a uma ou outra dimensão em particular. Para esses autores, somente a partir da ressignificação 
da sustentabilidade é que serão possíveis práticas verdadeiramente efetivas de responsabilidade social.

Os ODS têm uma contribuição importante a dar nesse sentido: para as Nações Unidas, eles “definem uma estrutura comum de ação e linguagem que ajudará as empresas a se comunicarem de forma mais consistente e efetiva com as partes interessadas a respeito do seu impacto e desempenho atual e futuro" (GLOBAL REPORTING INITIATIVE; UNITED NATIONS GLOBAL COMPACT; WORLD BUSINESS COUNCIL FOR SUSTAINABLE DEVELOPMENT, [2015], p. 6). As metas, por sua vez, auxiliam, na visão da entidade, a formação de parcerias para a resolução de problemas sociais complexos.

Batistella e Marchiori (2013) ressaltam que as práticas de sustentabilidade das organizações estão relacionadas aos processos comunicacionais em duas vias: a primeira, informacional, entendida como um processo linear de troca de informações nos fluxos formais de comunicação das empresas; e a segunda, de natureza relacional, compreendida como um "processo social multirreferencial que propicia a construção de sentidos, sempre renovados a partir de articulações entre as diferentes instâncias de emissão, circulação e recepção" (BATISTELLA; MARCHIORI, 2013, p. 114), fundamentais para a adaptação das organizações diante das exigências da sustentabilidade.

Nesse sentido, a comunicação para a sustentabilidade é entendida, em sua essência, como uma comunicação que implica construir uma nova visão de mundo pelas organizações e pela sociedade, contribuindo de forma decisiva para as necessárias transformações sociais para garantir o futuro do planeta. Para Kunsch e Moya (2014, p. 6), "somente por meio da comunicação será possível criar as bases das mudanças necessárias, com a maior conscientização dos governos, da iniciativa privada e dos segmentos representativos da sociedade civil". Dessa forma, a comunicação para a sustentabilidade "pode ser um agente de mudança e promover novas maneiras de um viver sustentável” (MOYA, 2016, p. 233), precisando para isso superar práticas fechadas, instrumentais e voltadas unicamente para os processos produtivos.

Deetz (2009) aponta a importância da comunicação na emergência de novas formas de gestão, provocadas pela insatisfação com a centralização do poder decisório. $\mathrm{O}$ autor defende novas "formações multiorganizacionais e de interesses, reunidas em torno da solução de problemas, superação de conflitos e/ou definição de cursos inovadores" (DEETZ, 2009, p. 99). Smith (2015), por sua vez, advoga um novo modelo de governança que parte da construção coletiva de soluções para enfrentar os desafios da 
sustentabilidade econômica, social e ambiental, para o qual as organizações devem buscar novas formas de comunicação baseadas "mais no conflito do que em modelos de comunicação centrados na pessoa ou orientados ao consenso" (DEETZ, 2009, p. 99).

Os estudos dão novo sentido para a comunicação nas organizações, fortalecendo sua função estratégica para a construção da cidadania e defesa dos interesses coletivos em detrimento dos interesses puramente econômicos. No caso dos negócios sociais, a comunicação mantém, em nossa análise, pontos de interlocução com os pressupostos da comunicação para a sustentabilidade e pode se beneficiar da abordagem dos estudos dessa área em diferentes aspectos. São comuns às práticas discursivas de ambos as noções de interesse público, trabalho coletivo, participação, engajamento a uma causa e transformação social.

Outro ponto de convergência diz respeito à possível contribuição da comunicação para esclarecer e popularizar conceitos, atingindo mais públicos. Do mesmo modo que o termo "sustentabilidade", a expressão "empreendedorismo social" tem sido apropriada por diferentes atores sociais e organizações, com diferentes intencionalidades. Divulgar a locução "negócios sociais" para os públicos e a sociedade como um todo ajudará a superar as incertezas e, ao mesmo tempo, ampliar a conscientização quanto ao lugar desses empreendimentos na resolução de problemas sociais complexos - que envolvem a participação de diferentes setores - e na agenda global e local da sustentabilidade. Nesse sentido, a comunicação dos negócios sociais também poderá se beneficiar de novas formas de comunicação e governança - mais adequadas aos formatos organizacionais híbridos -, com maior ênfase em processos colaborativos e participativos para a solução de problemas sociais.

\subsection{Negócios sociais: novas perspectivas para as relações públicas comunitárias}

Discutimos, neste item, aspectos das relações públicas comunitárias, em que a comunicação é compreendida sob uma lógica dialógica e transformadora, comprometida com os interesses de segmentos sociais organizados, em diálogo com os negócios sociais.

Em nossa análise, os negócios sociais emergem com um novo público no contexto - já amplo e diversificado - da comunicação comunitária e das relações públicas comunitárias. Com origem na década de 1980, também atrelada à redemocratização do país, e na articulação crescente dos movimentos sociais (KUNSCH, W., 2007), as relações públicas comunitárias estão vinculadas a atividades, projetos e programas de 
interesse coletivo em organizações dos três setores. No primeiro setor, manifestam-se na forma de políticas públicas, iniciativas de participação popular e parcerias públicoprivadas; no segundo setor, em ações de responsabilidade social corporativa; e no terceiro setor, mais recorrente na literatura sobre o tema, em instituições sem fins lucrativos que geram bens e serviços de caráter social, como movimentos sociais, instituições religiosas, centros comunitários e organizações de voluntariado, entre outras.

Quanto às frentes de atuação, Peruzzo (1993), numa perspectiva humanizada da profissão, elenca uma série de possibilidades para as relações públicas comunitárias. São "atividades, projetos e programas nos quais podemos fazer algo em prol do interesse genuíno de públicos ou do interesse público" (PERUZZO, 1993, p.6), sejam em organizações públicas ou privadas - com ou sem fins lucrativos - ligadas à defesa do bem comum ou ainda em movimentos sociais organizados. Para a autora, as relações públicas comunitárias, enquanto agentes de mudança e mobilização social, estão comprometidas com a redução das desigualdades sociais e promoção da cidadania.

Em um contexto brasileiro de conhecidos déficits nas áreas da educação, saúde, meio ambiente e habitação, as relações públicas têm a oportunidade de "exercerem sua função social, mediando movimentos organizados, órgãos públicos e empresas privadas no campo dos interesses das classes populares ou segmentos com interesses específicos" (SILVA; GUEDES, 2016, p. 8). Nesse sentido, as relações públicas comunitárias irão envolver os públicos em "iniciativas de mobilização social em busca de corresponsabilidade, engajadas em causas permanentes e não apenas em ações filantrópicas" (AMPARO; SILVA, 2015, p. 79) que contribuam de forma efetiva para a qualidade de vida da população.

Sob tais aspectos, as relações públicas comunitárias guardam similaridades com a definição e os objetivos dos negócios sociais, que se dedicam ao desenvolvimento de iniciativas inovadoras que visam à resolução de problemas da sociedade, fundamentados em valores de base ideológica e visões de mundo próprias para a solução de problemas sociais (SOCIAL ENTERPRISE KNOWLEDGE NETWORK, 2006), observados na tese de mudança do negócio.

Cabe às relações públicas comunitárias atuar junto aos atores sociais com o propósito de estimular a mobilização social e política, de modo participativo e democrático, tendo em vista "a problematização e transformação de suas realidades, de modo consciente, no exercício do papel de protagonistas de sua própria história" (SILVA; GUEDES; SANTOS, 2017, p. 92). Peruzzo (2007, p. 149) também enfatiza a participação 
como dimensão essencial das relações públicas comunitárias, as quais, para a autora, têm o "papel fundamental de facilitar o processo de ação coletiva", respeitando-o e tornandose parte integrante dele, recusando, desta forma, o papel a elas costumeiramente atribuído de consultor e mediador externo.

O estímulo à participação da comunidade é, portanto, outro aspecto comum entre as relações públicas comunitárias e os negócios sociais, uma vez que a literatura sobre o tema reforça o vínculo entre tais empreendimentos e o ambiente em que estão inseridos, seja pelas características da economia local, seja pelas necessidades específicas daquela comunidade (BARKI; AGUIAR, 2013). Perspectiva semelhante é compartilhada por Oliveira e Nader (2017), para quem o empreendedorismo social requer o estímulo à participação coletiva e crítica voltada à ação social e política.

Outro aspecto importante na interface entre as relações públicas comunitárias e os negócios sociais é a necessidade de conceber estratégias de comunicação para públicos comuns a ambos. Isso torna o ecossistema dos negócios sociais um campo de atuação, por excelência, das relações públicas comunitárias, as quais possibilitam diversas formas de mediação entre os três setores da sociedade, dado seu envolvimento significativo em todos eles, sobretudo no terceiro setor (KUNSCH, 2007b). Na articulação entre Estado, empresas e sociedade civil, cabe às relações públicas comunitárias repensar "o conteúdo, as formas, as estratégicas, os instrumentos, os meios e as linguagens das ações comunicativas com os mais diferentes grupos envolvidos, a opinião pública e a sociedade" (KUNSCH, 2007b, p. 178).

Cabe ao profissional de relações públicas, portanto, trabalhar estrategicamente os processos comunicativos das organizações, sensibilizar a sociedade e a opinião pública e estabelecer canais efetivos de interlocução com os diferentes setores da sociedade, e "a partir de um conjunto de técnicas subsidiadas por estratégias e programas de comunicação, auxiliar no desafio de construir uma nova realidade cidadã" (AMPARO; SILVA, 2015, p. 88). Nesse sentido,

em trabalhos de dimensão comunitária, é fundamental que ele se preocupe com
a comunicação simétrica de mão dupla, criando canais de diálogo,
estabelecendo políticas de portas abertas, procurando conhecer o perfil dos
públicos, realizando pesquisas de opinião, desenvolvendo planos de ação, tudo
de forma participativa (KUNSCH, 2007b, p. 176).

Herrera (2012) enumera alguns princípios das relações públicas no empreendedorismo social, entre os quais estão a implantação de trabalhos cooperativos, de corresponsabilidade e solidariedade; a organização de interconexões, formando 
parcerias e redes sociais; o fomento à cidadania ativa; a adoção de práticas e disseminação de uma educação libertadora; a democratização da propriedade; o incentivo a práticas de formas associativas de propriedade e de gestão; a construção de redes cooperativas e solidárias de intercâmbio comercial, técnico, cultural etc. em âmbito local, regional, nacional e global; a disseminação de práticas participativas de gestão; o empoderamento de cidadãos, da comunidade e da sociedade; e o uso do planejamento como processo de interferência na realidade de uma comunidade, a fim de transformá-la. Sob estes princípios, o planejamento de relações públicas comunitárias - alinhado ao plano de negócio e à tese de mudança dos negócios sociais - deve apresentar, com as adaptações necessárias, uma metodologia alternativa que enfatize "um trabalho engajado, no qual se priorizam a interação, a participação e a valorização de todos os envolvidos no processo" (KUNSCH, 2007c, p. 293), com o claro propósito de intervenção social.

Por fim, o que se sugere é uma visão ampla das relações públicas, tal qual proposta por Henriques (2007) e Kunsch (2007c), que defendem que as técnicas da profissão sejam adotadas, em seus fundamentos, em qualquer demanda de relacionamento entre organizações e seus públicos, "não no sentido propagandístico ou mercadológico, mas em uma acepção política da defesa pública de interesses por meio do relacionamento entre instituições e públicos" (HENRIQUES, 2007, p. 101). Trata-se, portanto, não somente de uma mudança de lugar de atuação, mas de uma "nova postura metodológica" de exercício profissional, com ênfase na função articuladora e gestora das relações públicas comunitárias na realidade social (CÉSAR, 2007, p. 83). A articulação dos negócios sociais com a área sugerida aqui apoia-se nesta perspectiva, que não restringe às relações públicas comunitárias os movimentos sociais ou a organizações do terceiro setor, podendo se dar em qualquer espaço de atuação, dependendo unicamente da postura do profissional.

A resolução de problemas sociais complexos e de grandes dimensões exige ampla parceria entre diferentes setores da sociedade e a participação ativa da comunidade local beneficiada. Nesse contexto, a comunicação e as relações públicas comunitárias poderão desempenhar função decisiva, desenvolvendo ações estrategicamente planejadas, de forma participativa, e que envolvam essas organizações e seus públicos, a opinião pública e a sociedade. Faz-se necessário ampliar os estudos acerca das possibilidades de atuação das relações públicas em estratégias de comunicação de novos modelos de negócios e novas formas de organização da sociedade, como é o caso dos negócios sociais. 
Em resumo, buscamos neste capítulo discutir o processo de comunicação em negócios sociais. Não é nossa intenção apresentar uma revisão teórica das temáticas do campo, mas articular conhecimentos oriundos dos referenciais teóricos da comunicação organizacional com o nosso objeto de estudo. Sob as dimensões da comunicação integrada, procuramos refletir sobre políticas e estratégias da comunicação administrativa, interna, institucional e mercadológica dos negócios sociais. Soma-se a isso a noção de públicos, própria da área de relações públicas, enquanto possível contribuição para o entendimento das especificidades dos atores do ecossistema de negócios sociais.

Este capítulo também explorou conhecimentos de outras duas linhas de pesquisa com literatura mais consolidada no campo da comunicação: contemporâneos aos negócios sociais, os estudos sobre a comunicação para a sustentabilidade - ligada às grandes empresas - e as relações públicas comunitárias - vinculadas ao terceiro setor e aos movimentos sociais - são duas interpretações possíveis para a reflexão sobre o potencial da comunicação para conscientizar e mobilizar pessoas a fim de promover mudanças positivas na sociedade.

Isso posto, discutimos a seguir os resultados da etapa de pesquisa empírica, da qual emergem as possíveis correlações, com suas contribuições e contradições, entre teoria e prática da comunicação em negócios sociais. 
Neste capítulo, apresentamos o estudo de caso único e representativo do ecossistema investigado: o Quintessa, uma aceleradora de negócios sociais localizada na cidade de São Paulo. Esta etapa da pesquisa seguiu o referencial teórico descrito no Capítulo 2, no qual justificamos a opção pelo estudo de caso tal qual proposto por Yin (2001). Definidas naquele capítulo as estratégias metodológicas, partimos para a consolidação do protocolo de estudo de caso (Quadro 3), conforme descrito a seguir.

Num primeiro momento, selecionamos o estudo de caso, que inclui a escolha da aceleradora e dos negócios sociais para compor esta etapa da pesquisa. Trata-se de uma amostra intencional (por julgamento), ou seja, por critérios estabelecidos pela própria pesquisadora e de acordo com os objetivos deste estudo. Os critérios para a escolha da aceleradora incluem:

- tempo de atuação do mercado;

- representatividade no setor;

- vinculação aos ODS; e

- aceite em participar da pesquisa.

Quanto aos negócios sociais selecionados para o estudo, foram estabelecidos os seguintes critérios:

- ter objetivos sociais identificados nos ODS;

- ter participado de um programa de aceleração do Quintessa;

- estágio de maturidade do negócio, em conformidade Quintessa (2017)

Na sequência, o estudo foi organizado em três etapas:

a) pesquisa documental: com análise descritiva de documentos cedidos pela organização (site, apresentações, entrevistas, entre outros materiais institucionais);

b) entrevistas em profundidade com membros do Quintessa: foram entrevistados dois funcionários e uma mentora ligada à área de comunicação. As respostas foram o ponto de partida para desenvolvermos uma análise descritiva da comunicação da aceleradora;

c) entrevistas em profundidade com negócios sociais: foram realizadas três entrevistas em profundidade com dirigentes da Banca do Bem, 4YOU2 e E-Moving, negócios acelerados pelo Quintessa. 
Quadro 3 - Protocolo para estudo de caso

\begin{tabular}{|c|c|c|c|}
\hline Fase do protocolo de & Etapas & Instrumentos & Estratégias \\
\hline \multirow{3}{*}{ 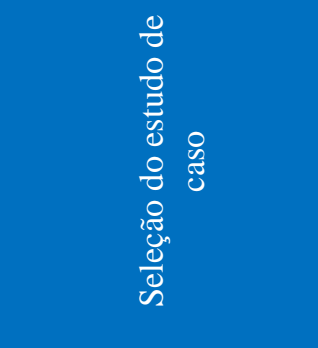 } & Seleção da aceleradora & Amostragem & Amostragem intencional e não aleatória \\
\hline & Seleção de três negócios acelerados & Amostragem & Amostragem intencional e não aleatória \\
\hline & Carta-convite & Carta (Apêndice A) & $\begin{array}{l}\text { Envio por e-mail e comprovação de } \\
\text { vínculo com a Universidade de São } \\
\text { Paulo }\end{array}$ \\
\hline \multirow{4}{*}{ 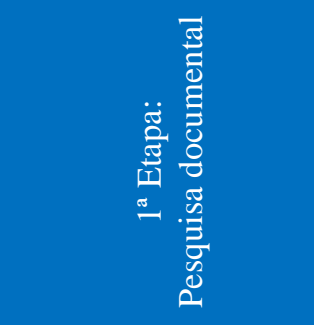 } & Informações gerais sobre o Quintessa & Site, redes sociais & Análise descritiva \\
\hline & Publicações & $\begin{array}{l}\text { Apresentação institucional, Guia 2.5: guia para o } \\
\text { desenvolvimento de negócios de impacto }\end{array}$ & Análise descritiva \\
\hline & Entrevistas na imprensa & Portais Draft, Notícias de Impacto, Revista Trip & Análise descritiva \\
\hline & Participação em eventos & Evento Histórias que só o Quintessa Pode Contar & Observação direta \\
\hline \multirow{3}{*}{ 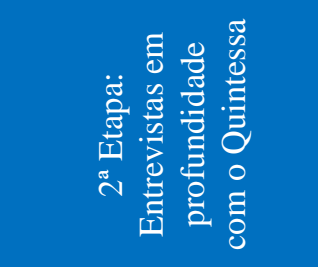 } & $\begin{array}{l}\text { Thaís Fontoura - busca e seleção de } \\
\text { novos negócios }\end{array}$ & Roteiro de perguntas (Apêndice B) & Análise descritiva e análise de conteúdo \\
\hline & Maércio Diogo - gestor de projetos & Roteiro de perguntas (Apêndice B) & Análise descritiva e análise de conteúdo \\
\hline & Luciana Branco - mentora & Roteiro de perguntas (Apêndice B adaptado) & Análise descritiva e análise de conteúdo \\
\hline \multirow{3}{*}{ 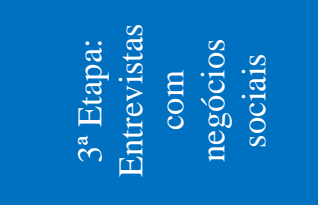 } & 4YOU2 (escola de inglês) & Roteiro de perguntas (Apêndice C) & Análise de conteúdo \\
\hline & E-Moving (bicicletas elétricas) & Roteiro de perguntas (Apêndice C) & Análise de conteúdo \\
\hline & Banca do Bem (e-commerce) & Roteiro de perguntas (Apêndice C) & Análise de conteúdo \\
\hline
\end{tabular}

Fonte: Elaborado pela autora. 
A cada etapa do estudo somaram-se reflexões extraídas da etapa anterior, permitindo, ao final da terceira etapa, uma visão mais abrangente e conclusiva dos dados coletados na pesquisa empírica.

\subsection{Pesquisa documental (primeira etapa)}

A pesquisa documental foi utilizada na primeira etapa deste estudo de modo que a pesquisadora pudesse compreender melhor o Quintessa. A coleta de dados compreendeu diversificada documentação cedida pela aceleradora:

- as duas edições do Guia 2.5: guia para o desenvolvimento de negócios de impacto (www.guiadoisemeio.com.br);

- site (www.quintessa.org.br), apresentação e vídeo institucionais;

- redes sociais (páginas oficiais no Facebook, LinkedIn e Instagram, incluindo os perfis pessoais das diretoras no LinkedIn);

- newsletter bimestral do Quintessa;

- notícias e reportagens na imprensa (DATT, 2019; EIROA, 2018; GONÇALO JUNIOR, 2018; LEUZINGER, 2018) e entrevistas das diretoras e de profissionais (ARANHA, 2018; CERIDONO, 2019) e do fundador (LEO..., 2017);

- participação no encontro da série Impacto e Retorno Financeiro: Histórias que só o Quintessa Pode Contar, realizado no dia 16 de maio de 2019.

Visando embasar a coleta de dados, foram observados os seguintes pontos:

- se os dados levantados permitiam constituir uma análise social e histórica do Quintessa, para fins de contextualização da etapa seguinte;

- quais são a missão, a visão e os valores do Quintessa;

- a caracterização do modelo de negócios da aceleradora, incluindo os serviços oferecidos aos empreendedores sociais; e

- características da estrutura administrativa e da cultura organizacional do Quintessa para posterior reflexão sobre a comunicação administrativa e interna da aceleradora.

A descrição das evidências coletadas a seguir, organizada na forma de uma narrativa, permitiu identificar dados e informações relevantes para a pesquisa, aos quais se somam insights da pesquisadora. A análise descritiva desta etapa do estudo segue 
roteiro adaptado de proposta de Kunsch (2016) para questionário de pesquisa institucional e contempla os seguintes itens: identificação e dados gerais, história, infraestrutura física, serviços, estrutura organizacional e administrativa e cultura organizacional.

\subsection{Análise descritiva da pesquisa documental: perfil institucional do Quintessa}

\subsubsection{Identificação e dados gerais}

A Associação Quintessa é o nome empresarial que atende pelo nome fantasia Quintessa, uma associação privada com sede no espaço CIVI-CO, um coworking para empreendedores sociais localizado à Rua Dr. Virgílio de Carvalho Pinto, 445, em Pinheiros, na cidade de São Paulo. A aceleradora atua no ramo de serviços de consultoria e gestão para negócios sociais e programas de parceria com empresas, funcionando num modelo de gestão híbrido. O Quintessa foi fundado pelo administrador e economista Leo Figueiredo, ex-executivo da Hedging-Griffo, e desde 2017 é dirigido pelas administradoras de empresa Anna de Souza Aranha e Gabriela Bonotti.

Não foram divulgados dados de patrimônio e situação econômica da aceleradora.

\subsubsection{História}

Prestes a completar dez anos, o Quintessa foi fundado no final de 2009 por Leo Figueiredo, que, após mais de 30 anos no mercado financeiro, decidiu deixar a área para fundar o então Instituto Quintessa, com a finalidade de auxiliar e impulsionar uma nova forma de fazer negócios. Tem como premissa a ideia de que o empreendedorismo é capaz de resolver problemas sociais e ambientais. Para o fundador, o empreendedor deve ter consciência do seu papel na sociedade: toda a riqueza gerada por ele em seu negócio deve ser estendida à sociedade "não como retribuição, mas como uma missão" (LEO..., 2017). Sobre a iniciativa de Leo Figueiredo, a diretora do Quintessa Gabriela Bonotti comenta em entrevista para a revista Draft:

Ele sabia o quão solitária é a decisão do empreendedor e queria dedicar sua experiência para ajudar outros empreendedores. Além disso, desejava deixar um legado de impacto positivo. Na época não existia o conceito de "negócios de impacto", então foi um movimento intuitivo de enxergar as empresas como um veículo para geração de impacto (LEUZINGER, 2018, n. p.). 
O nome escolhido, "Quintessa", remete à essência de algo puro e concentrado. Conforme descrito no site da aceleradora, "uma palavra que simboliza aquilo que não vemos, não tocamos, mas que traz sentido e conecta a todos" (QUEM..., c2019), que sugere ir além do conhecimento técnico e dar atenção a aspectos invisíveis e intangíveis dos negócios.

Em sua origem, o Quintessa arrecadava recursos com doações do fundador e, por dois anos, de 2009 a 2011, dedicou-se a apoiar gratuita e exclusivamente empreendedores da base da pirâmide. $\mathrm{O}$ modelo, contudo, não apresentava sustentabilidade financeira, o que fez a organização optar por um reposicionamento estratégico do negócio. No ano seguinte, Gabriela Bonotti e Anna Aranha passaram a integrar a equipe e a sustentabilidade financeira tornou-se uma preocupação maior.

A seguir, uma linha do tempo situa o Quintessa na cronologia das organizações de apoio aos negócios sociais (Figura 10), pela qual se observa o crescimento expressivo desse tipo de empreendimento ao longo das duas últimas décadas.

Figura 10 - Linha do tempo: ano de fundação das organizações de apoio aos negócios sociais

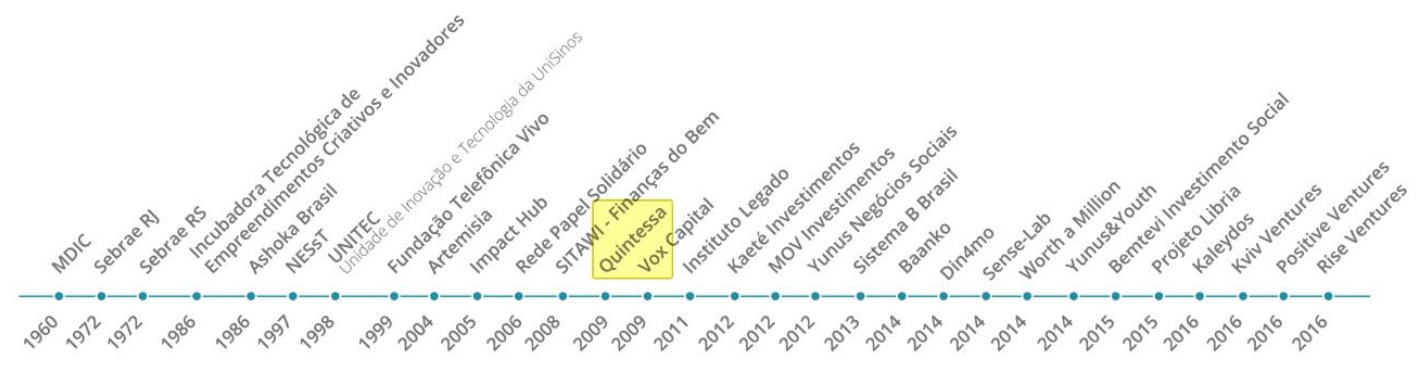

Fonte: Guia 2.5, documento cedido pelo Quintessa.

Os anos de 2012 a 2015 foram um período de testes e consolidação do novo modelo de negócios, especialmente dos programas de aceleração de negócios sociais, com duração variável de seis meses a dois anos. Em 2013, o Quintessa tem seu maior case de sucesso até então: a 4YOU2, escola de inglês criada com o objetivo de proporcionar um ensino de línguas de qualidade e acessível a pessoas das classes CDE. Segundo a primeira edição do Guia 2.5, em quase dois anos de aceleração o Quintessa abordou diferentes aspectos do negócio: estruturação de processos e gestão de pessoas, redesenho dos produtos e precificação, gestão financeira, metas comerciais, modelo 
societário, assessoria jurídica, modelo de expansão, acompanhamento de indicadores de resultados, pontes com potenciais clientes e preparação para a captação de investimentos. Uma parceria com o portal Catraca Livre - acelerado pelo Quintessa - e a publicação de reportagens sobre negócios e iniciativas da aceleradora ajudaram a visibilidade do negócio, na avaliação do fundador (GONÇALO JUNIOR, 2018). Em 2015, o Quintessa lança a primeira edição do Guia 2.5: guia para o desenvolvimento de negócios de impacto.

Em 2016, um novo ponto de virada para o Quintessa: a diversificação do portfólio. Além dos programas de aceleração, passam a ser oferecidos o programa de assessoria na captação de investimentos, que auxilia o empreendedor a captar fundos com investidores, e os programas de parcerias, com o objetivo de conectar negócios sociais e empresas. Desde aquele ano, o negócio sobrevive com receitas próprias (GONÇALO JUNIOR, 2018).

Em 2017, Leo Figueiredo se afasta da gestão do Quintessa, passando a colaborar somente como mentor dos programas de aceleração, e Anna Aranha e Gabriela Bonotti assumem a direção. No mesmo ano, o Quintessa lança a segunda edição do Guia 2.5. Em 2018, a aceleradora lança três programas de seleção, mentoria e captação de recursos para negócios sociais: o Sponsorship Quintessa, o programa Hangar Social, em parceria com o CIVI-CO e a Pipe Social, e o Programa Realiza!, em parceria com a Kaleydos, plataforma de investimento e desenvolvimento de negócios.

Em 2019 são estabelecidas duas parcerias com grandes empresas: com o grupo Braskem o Quintessa desenvolve o Braskem Labs Scale, que seleciona negócios para geração de impacto positivo com o uso de plástico ou química; e com a AMBEV participa do Programa Voa, que oferece a organizações não governamentais mentorias gratuitas em planejamento, orçamento, captação de recursos e gestão de pessoas.

O Quintessa também esteve envolvido em duas chamadas públicas: em parceria com o Instituto Vedacit, braço de responsabilidade social da Vedacit (da área de construção civil), desenvolve o Mapa cidades sustentáveis, que busca dar visibilidade para organizações que têm o propósito de tornar as cidades brasileiras mais sustentáveis; é também um dos apoiadores da chamada Território de Futuro, liderado pelo grupo Marquise (construtora e incorporadora), para busca e seleção de negócios nas áreas de infraestrutura e serviços de ambientes urbanos no Ceará. 


\subsubsection{Infraestrutura física}

Desde janeiro de 2018 o Quintessa é um dos 64 residentes do CIVI-CO, espaço de coworking composto por organizações que atuam em projetos de impacto social. Inaugurado em novembro de 2017, o CIVI-CO se inclui em um segmento em alta no Brasil, o coworking de nicho, e se propõe, nas palavras de um dos seus fundadores, Ricardo Podval, em entrevista à Revista Pequenas Empresas \& Grandes Negócios, "a ser uma ponte entre negócios sociais, área pública e a sociedade” (DATT, 2019, n. p.).

Sobre a sede, Gabriela Bonotti afirma:

A principal vantagem é o alinhamento de propósito, já que o CIVI-CO também existe para causar impacto e contribuição social para o país. [...] Por ser um espaço que se propõe a debates, há um fluxo de empreendedores de impacto muito interessante, que não se limita aos residentes. É gente que vem para algum evento no auditório ou "bater papo com uma startup", e que podemos prospectar em busca de possíveis novos acelerados (LEUZINGER, 2018, n. p.).

O CIVI-CO ${ }^{28}$ conta com escritórios, auditório, espaço para eventos e um café. Busca empreendedores cívico-sociais que, na definição dos sócios, são pessoas dispostas a trabalhar em políticas públicas do país para uma sociedade mais justa e engajada, para além do negócio que representam (LIRA, 2017). Ainda segundo os sócios, o candidato à residência precisa ser baseado em algum dos 17 ODS da ONU (EIROA, 2018).

Residente do CIVI-CO desde o início de 2019, a mentora do Quintessa Luciana Branco, da agência de comunicação [EM BRANCO], elogia a proposta do lugar: "Para mim é como se eu estivesse a vida inteira lá. Eu sou completamente fascinada por aquele lugar. [...] É mais do que inspirador, convoca para colocar em prática" ${ }^{29}$.

Praticidade, redução de despesas e um ambiente em que pudesse estar conectado a outras organizações do ecossistema de negócios sociais levaram o Quintessa ao CIVICO. Em entrevista para a Revista Trip, a diretora Anna Aranha afirma que "já nos conectamos a diversas iniciativas e empreendedores, que se tornaram potenciais parceiros

\footnotetext{
${ }^{28}$ No final de 2018, o espaço envolveu-se em uma polêmica pública ao dispensar uma recepcionista após término de contrato (de pessoa jurídica), de seis meses. O complicador é que ela tinha comunicado poucos dias após a seleção para a vaga que estava grávida. O CIVI-CO divulgou nota dizendo que a contratação por período determinado foi "em comum acordo" e que o desligamento se deu "após o encerramento da vigência contratual" (HERDY, 2018, n. p.). A notícia repercutiu na mídia e rendeu comentários negativos nas redes sociais, apontando a contradição entre os valores organizacionais e o posicionamento do CIVI$\mathrm{CO}$ no episódio. Após reunião com residentes e funcionários, o CIVI-CO convidou a ex-funcionária para se reintegrar à equipe, em regime CLT, e afirmou ter pagado a licença-maternidade e os direitos devidos à recepcionista (FONSECA, 2018).

${ }^{29}$ Os trechos grafados em itálico correspondem a informação oral coletada nas entrevistas realizadas neste estudo.
} 
para expandirmos geograficamente nossa atuação" (EIROA, 2018, n. p.). Sobre a sede, a publicitária Thaís Fontoura, funcionária do Quintessa e uma das entrevistadas neste estudo, destaca, entre os pontos positivos, o fato de o espaço já ser bem conhecido entre os empreendedores sociais, o contato direto e espontâneo com atores do ecossistema e o fato de o espaço ser muito frequentado, especialmente em dia de eventos. O CIVI-CO é muito aberto à realização de eventos do Quintessa, de acordo com a profissional (Figura 11): "Pra gente faz todo o sentido estar aqui dentro [...] o CIVI-CO virou uma referência de inovação e impacto social", disse Thaís Fontoura.

Figura 11 - Noite dos mentores do Quintessa no CIVI-CO

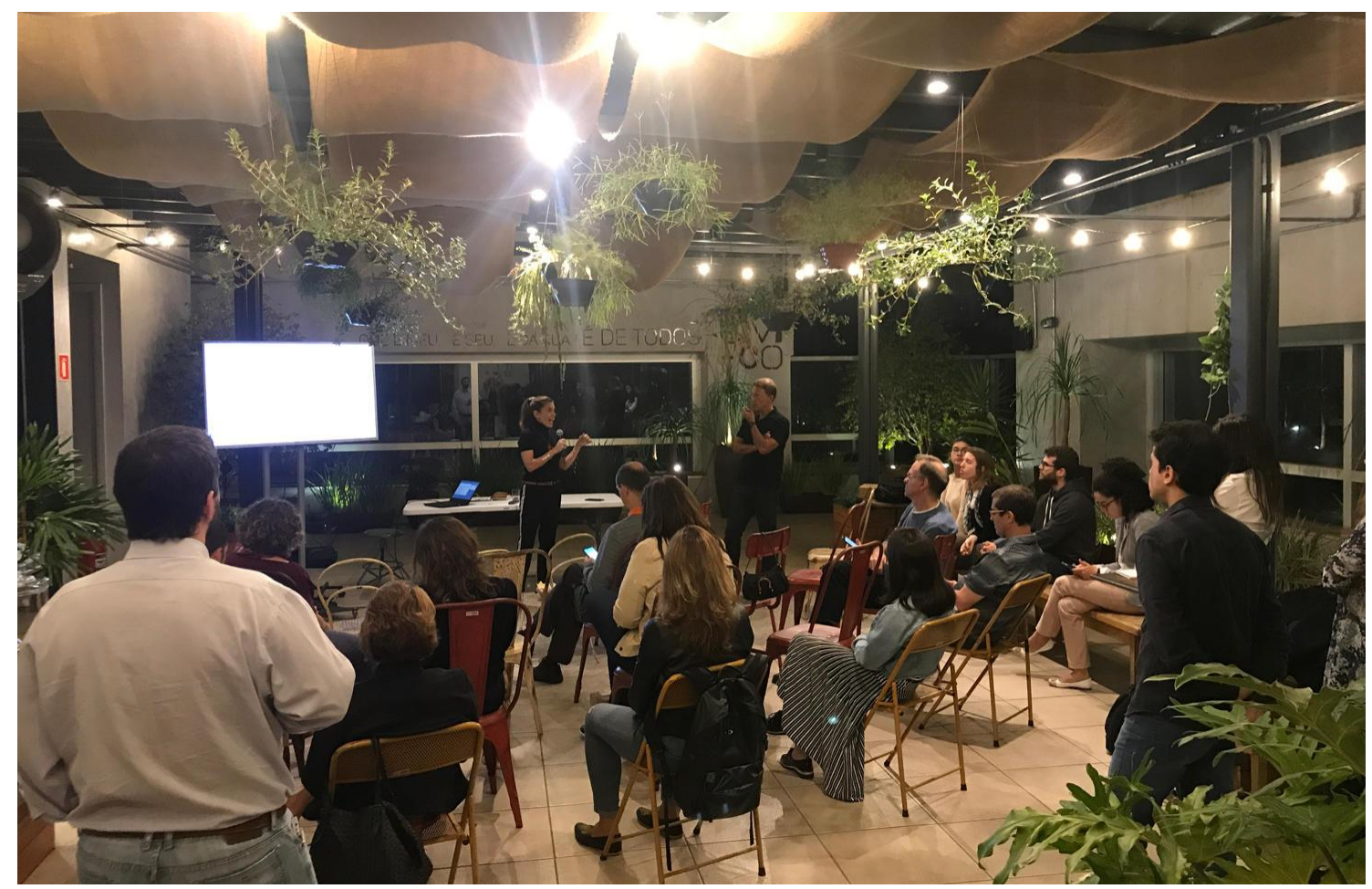

Fonte: Entrevistada Thaís Fontoura.

\subsubsection{Serviços}

O Quintessa atua com fins de estruturar a gestão, impulsionar o crescimento e captar investimentos para negócios que buscam resolver desafios sociais e ambientais. Nas palavras da diretora Anna Aranha e reproduzida na apresentação institucional, "no Quintessa desejamos transformar a realidade do país pelo empreendedorismo: existimos para impulsionar uma nova forma de fazer negócios, garantindo o sucesso de empresas que resolvem os desafios centrais da sociedade" (QUEM..., c2019). Na prática, a ideia é 
acelerar, como o próprio nome sugere, o processo de maturidade do negócio, ou seja, fazer a empresa chegar mais rápido num patamar que levaria mais tempo para ser atingido sem a aceleração.

Algumas outras aceleradoras que atuam neste setor são: NESsT, Artemisia e Yunus Negócios Sociais Brasil. O Quintessa aponta como seu diferencial nesse mercado o suporte personalizado aos empreendedores e suas equipes, por meio de programas de aceleração customizados para cada negócio. O Quintessa não visa "prestar um serviço", e sim "estar a serviço" do empreendedor, explica Anna Aranha no vídeo institucional, com foco na entrega de resultados para o negócio acelerado. Em entrevista, a diretora explica ainda como é feito o atendimento aos negócios:

Customizamos o programa de acordo com os desafios prioritários de cada negócio, nos dedicamos 8h/semana a nossos gestores e quinzenalmente a nossos mentores, e dedicamos um ano no programa, permitindo que atuemos desde a identificação dos desafios até o refinamento das soluções implementadas (ARANHA, 2018, n. p.).

Os serviços oferecidos pelo Quintessa estão divididos em três programas. São eles:

a) Programas de Aceleração: criados oficialmente em 2010, são o principal serviço oferecido pelo Quintessa aos negócios sociais em estágios 2 a $6^{30}$, com ênfase no desenvolvimento da gestão. O objetivo desses programas é "auxiliar em processos de validação, estruturar a gestão e impulsionar o crescimento de negócios de impacto", segundo a apresentação institucional (QUEM..., c2019). São três programas de aceleração, conforme o estágio do negócio:

- validação: com duração de quatro a cinco meses;

- tração: com duração de 12 meses;

- escala: com duração de seis a sete meses.

De abrangência nacional, os programas oferecem ao empreendedor social suporte em diferentes frentes:

- mentoria e suporte em gestão: auxílio em decisões estratégicas e acompanhamento de resultados nas áreas comercial, de gestão de pessoas, planejamento estratégico, plano

\footnotetext{
${ }^{30}$ Adotamos, aqui, a classificação do Guia 2.5 para estágio de negócios, já citada no Capítulo 3.
} 
de expansão, modelo de negócio, modelo societário, financeiro, operação, cultura organizacional, estrutura de capital e governança;

- desenvolvimento pessoal do empreendedor: coaching individual;

- rede de contatos do Quintessa: conexão com potenciais investidores, parceiros e clientes, redes de mentores e empreendedores. A aceleradora também oferece a divulgação do negócio acelerado na mídia e nas redes sociais.

São três critérios de seleção principais:

- o impacto: relevância do problema social e da solução apresentada pelo empreendedor, alinhamento entre objetivos sociais e sustentabilidade financeira do negócio;

- o empreendedor e a equipe: perfil do empreendedor, engajamento da equipe e dedicação integral ao negócio;

- o negócio: estágio de desenvolvimento, mercado potencial, possibilidade de crescimento e inovação da solução.

Com duração de quatro semanas, o processo de seleção dos programas de aceleração é aberto durante todo o ano, uma vez que o atendimento aos negócios é individualizado e personalizado. São cinco etapas, do entendimento inicial do plano de negócios e apresentação do Quintessa até a aprovação no Conselho Gestor, passando pelo entendimento detalhado do negócio, reunião com o mentor e construção do case. O longo processo é importante para alinhar as expectativas, permitindo uma investigação aprofundada do negócio. Os ODS auxiliam no entendimento e enquadramento do negócio, mas o Quintessa também se vale de pesquisas próprias para avaliar a relevância do problema social e da solução oferecida pelo empreendedor.

Os programas de aceleração do Quintessa têm três grandes pilares: estratégia de negócio, gestão de pessoas e vendas, sendo que este último visa estruturar uma área comercial do negócio e aperfeiçoar canais de vendas. Já as estratégias de marketing irão depender do cliente que o negócio quer atingir: para os públicos $\mathrm{B} 2 \mathrm{~B}$, a aceleração é direcionada para um bom pitch de vendas e relacionamento com o cliente; para os públicos Business-to-Consumer (B2C) há foco maior no marketing digital, se atender ao perfil do negócio acelerado.

A aceleração, por sua vez, também se divide em três etapas: conhecer o negócio, construir a solução junto com o empreendedor e prepará-lo para dar andamento ao trabalho que foi feito sem a ajuda do Quintessa. Uma vez por ano, o Quintessa se reúne 
com o negócio acelerado para uma avaliação dos resultados e prospecção da possível adesão ao programa de assessoria para captação de investimentos.

Recentemente, o Quintessa participou de um modelo diferenciado de aceleração com o Programa Hangar, em parceria com o CIVI-CO e a Pipe Social. Com três meses e meio de duração, o programa promoveu encontros entre empreendedores de 15 negócios sociais entre novembro de 2018 e março de 2019, o Confraria Hangar. Em complemento, eles também receberam suporte individual dos gestores de projetos do Quintessa. Ao final do processo, a turma Hangar-001 apresentou um pitch dos negócios para potenciais empreendedores em um demoday.

De acordo com o portfólio disponível no site da aceleradora, 62 negócios já foram acelerados pelo Quintessa.

b) Assessoria para Captação de Investimentos: programa de abrangência nacional e oferecido a negócios nos estágios 5 e 6, tem como objetivo auxiliar os empreendedores a captar recursos, dando mais tempo a eles para se dedicarem ao negócio e, ao mesmo tempo, atraindo o que o Quintessa chama de "investidores qualificados". O suporte ao empreendedor social se dá na análise de perfil dos investidores, suporte na negociação e fechamento do contrato, passando por ajustes no decorrer das negociações e indicação de escritórios parceiros para assessoria jurídica. Como diferencial, a possibilidade de conexão com potenciais investidores. No portfólio do Quintessa para este programa está a Hand Talk, com a qual a aceleradora colaborou na captação de R \$ 2,5 milhões em 2018. O programa foi criado em 2016 pela aceleradora.

c) Programas de Parcerias: a proposta dos programas é tornar o Quintessa uma ponte entre empresas, instituições e fundações e o ecossistema de negócios sociais. Os programas são desenhados conforme a demanda de cada parceiro, atuando em temáticas como inovação, corporate venture, novos negócios, impacto socioambiental positivo e sustentabilidade. No portfólio da aceleradora constam parcerias com as seguintes organizações: WhizHealth (saúde), Kaleydos (investimentos), Instituto Arapyaú (sustentabilidade), In3Citi (inovação social) e Unibes Cultural (empreendedorismo e Cultura), que já atuam no ecossistema de negócios sociais, e Trigg (finanças), SENAC (educação), Instituto BRF (responsabilidade social), AMBEV (empreendedorismo social) e Braskem Labs (inovação e sustentabilidade). 


\subsubsection{Estrutura organizacional e administrativa}

O Quintessa se organiza em dois grandes times: busca e seleção de novos negócios e gestão de projetos.

O time de busca e seleção de novos negócios é formado por quatro pessoas, entre elas a diretora Anna Aranha. A prospecção de negócios divide-se em prospecção ativa (predominante), prospecção passiva e processo de seleção de novos negócios. É também responsável pela comunicação do Quintessa e pela prospecção de parcerias estratégicas com grandes empresas.

As atividades da equipe de busca e seleção de novos negócios são divididas da seguinte maneira: uma funcionária, no caso, a diretora Anna Aranha, atua na prospecção de empresas e investidores para os programas de parcerias; dois funcionários dedicam-se ao processo seletivo de novos negócios; e uma funcionária trabalha na prospecção ativa e na comunicação da aceleradora.

Já a equipe de gestão de projetos é responsável pelo atendimento aos empreendedores nos programas de aceleração. Para cada negócio acelerado, o Quintessa aloca um mentor - outros mentores podem ser acionados durante a aceleração para auxiliar em demandas específicas do empreendedor - e um gestor, que atende semanalmente o negócio acelerado. Em entrevista, Gabriela Bonotti explica que "os gestores são as pessoas que estão aqui full time, que tocam o dia a dia das acelerações, com um dia inteiro de dedicação por semana junto à startup" (LEUZINGER, 2018, n. p.). Cada gestor costuma ficar responsável por três a quatro negócios em processo de aceleração.

Em termos gerais, a equipe do Quintessa é pequena, com 13 funcionários, e tem perfil relativamente homogêneo: adulto-jovem, sendo nove mulheres e quatro homens; trabalham há pouco tempo no Quintessa (há até 3 anos); com ensino superior completo (exceto pela estagiária); predominantemente formados em Administração de Empresas, seguida dos cursos de Engenharia de Produção e Publicidade e Propaganda, em instituições como Fundação Getúlio Vargas (FGV), Universidade Federal de São Carlos (UFSCar) e Escola Superior de Propaganda e Marketing (ESPM). Entre os integrantes do grupo há profissionais que já atuaram em outras organizações do ecossistema de impacto (ICE e Sitawi Finanças do Bem) ou tiveram experiências anteriores como empreendedores sociais (nos negócios Cultivar: Novos Caminhos do Campo à Mesa, 3Marias e Caraca!). Em termos de tamanho da equipe de trabalho, verifica-se o 
crescimento do Quintessa após a criação dos novos programas: de seis funcionários em 2017, passando para 12 no final de 2018 e com expectativa de chegar a 15 até o final de 2019. A seguir, apresentamos um breve perfil das duas diretoras do Quintessa:

- Anna de Souza Aranha: em nossos estudos, a diretora foi identificada como principal porta-voz da empresa em entrevistas e eventos do setor e, portanto, fonte de observação direta e análise documental da pesquisadora. Formada em Administração Pública pela FGV, complementou seus estudos na Stanford University Graduate School of Business (Stanford Ignite) e Singularity University (Digital Education Program), nas áreas de empreendedorismo e inovação. É também cofundadora do Intento DFW, plataforma para o desenvolvimento de lideranças com integridade, e professora no MBA de Business Innovation da Faculdade de Informática e Administração Paulista (FIAP). Desde 2012, atua no Quintessa.

- Gabriela Bonotti: é formada em Administração pela FGV, com formação complementar na Universidade de Salamanca (Administração e Gestão de Empresas). Desde 2012, atua no Quintessa, inicialmente como gestora de projetos e, desde 2017, como diretora.

Elemento importante da cultura organizacional do Quintessa é o chamado suporte "mão na massa", ressaltado no discurso da equipe de trabalho: "nós desenvolvemos uma parceria super próxima com nossos acelerados e colocamos a mão na massa junto com eles. E não só com o empreendedor, mas com o time todo", conta a diretora Gabriela Bonotti (LEUZINGER, 2018, n. p.). Também em entrevista, João Ceridono (2019, n. p.), gestor de projetos, reafirma tal postura:

\footnotetext{
Na prática é parecido com uma consultoria, mas só para startups, e tem outra diferença da consultoria "normal", que é muita mão na massa. Então não só damos a nossa opinião do que deve ser feito, nós também ajudamos a implementar.
}

O Quintessa conta ainda com a colaboração de 48 mentores, que oferecem orientação gratuita aos negócios acelerados, em diferentes áreas de atuação. Entre os mentores do Quintessa estão alguns profissionais ligados à comunicação e ao marketing: a já citada Luciana Branco, sócia-fundadora da [EM BRANCO], que desenvolve planos de comunicação para clientes na área cultural; Leonardo Almeida Byrro, ex-gerente de marketing da Skol; Luiz Kroeff, especialista em planejamento de marcas e comunicação; e Marina Dolinsky, do Twitter Brasil e consultora em gestão e cultura organizacional. 
Os mentores são todos voluntários que dedicam duas horas quinzenais em reuniões com os acelerados do Quintessa: “Com isso, além de ser personalizada para cada negócio, a aceleração oferece para o empreendedor um contato muito próximo e uma relação de longo prazo", explica Gabriela Bonotti (LEUZINGER, 2018, n. p.). Não há uma prospecção de mentores; eles chegam espontaneamente ao Quintessa e passam a integrar o grupo após um alinhamento de expectativas, liderado pela própria diretora. Outra preocupação da aceleradora é não ter mentores ociosos; ou seja, só são mantidos no portfólio mentores ativos nos programas de aceleração.

\subsubsection{Cultura organizacional}

O Quintessa não apresenta diretrizes estratégicas classificadas em missão, visão e valores como é recorrente em grandes empresas (KUNSCH, 2016). Contudo, tais elementos estão presentes na documentação analisada neste estudo e puderam ser inferidos pela pesquisadora. A missão da aceleradora pode ser contemplada no propósito de "impulsionar uma nova forma de fazer negócios, garantindo o sucesso de empresas que resolvem os desafios centrais da sociedade" (QUINTESSA, 2019). Enquanto visão de negócio, o Quintessa objetiva transformar a realidade do país pelo empreendedorismo, ressignificando a ação das empresas para a geração de impacto social.

Entre os valores organizacionais, ressaltamos duas afirmações da aceleradora. $\mathrm{O}$ Quintessa diz estimular que os negócios tenham "uma gestão consciente e humana" (QUINTESSA, 2019). Em outro trecho da apresentação institucional, a aceleradora afirma: "Prezamos pela profundidade na atuação, pelo relacionamento próximo, de confiança e parceria, com o compromisso em entregar resultados relevantes e com excelência" (QUINTESSA, 2019).

Ainda entre as diretrizes estratégicas da aceleradora, são apontadas cinco características da atuação do Quintessa em negócios sociais: personalização no atendimento, equipe dedicada, contato próximo com o empreendedor, suporte "mão na massa" e relação em longo prazo com o negócio acelerado.

A aceleradora se preocupa em se distinguir de outros serviços de mercado: o Quintessa não se reconhece, por exemplo, como uma consultoria, que, na visão da aceleradora, é mais impessoal e baseada em uma cartela de soluções para a contratação do empreendedor. O Quintessa também não se identifica como uma escola de formação, em que o empreendedor participa de um workshop sobre técnicas de gestão e 
desenvolvimento para depois buscar aplicá-las no seu próprio negócio. A aceleração de um negócio no Quintessa configura-se, principalmente, como um processo individualizado e personalizado entre aceleradora e empreendedor social.

\subsection{Entrevistas em profundidade com o Quintessa (segunda etapa)}

Após contato inicial com o Quintessa e seu aceite em participar da pesquisa, fomos encaminhados para a publicitária Thaís Fontoura para dar andamento aos trabalhos. Realizamos duas entrevistas em profundidade com profissionais do Quintessa: uma com a própria Thaís Fontoura, da equipe de busca e seleção de novos negócios, e outra com o economista Maércio Diogo, um dos gestores dos programas de aceleração.

Com duração de cerca de 1h30, as entrevistas foram organizadas em blocos temáticos que contemplaram: história de vida profissional e ingresso na aceleradora, os programas de aceleração do Quintessa (principalmente com o gestor), a comunicação em negócio sociais, a comunicação do Quintessa (principalmente com a publicitária), comunicação e sustentabilidade e desafios e oportunidades do setor. Após acerto prévio com os entrevistados, as conversas foram gravadas para posterior análise das respostas.

Visando embasar a elaboração do roteiro de entrevistas (Apêndice B), foram observados os seguintes pontos:

- instrumentos e técnicas de comunicação adotados pelo Quintessa;

- as práticas de comunicação institucional da aceleradora, sobretudo para missão, visão e valores institucionais;

- estratégias de comunicação adotadas para cada público;

- se havia coerência entre as ações de comunicação praticadas no cotidiano do Quintessa e as práticas comunicacionais difundidas nos programas de aceleração;

- se a comunicação possuía valor estratégico na aceleradora;

- se há diferenças na abordagem comunicacional dependendo do estágio do negócio;

- se a sustentabilidade é um fator estratégico para a aceleradora; e

- se a sustentabilidade é contemplada nas práticas comunicacionais da aceleradora.

Apresenta-se a seguir um breve currículo de cada profissional entrevistado:

- Thaís Fontoura: é formada em Publicidade e Propaganda pela ESPM. Antes do Quintessa, trabalhou por um ano na Unilever, sendo responsável pelo 
acompanhamento da comunicação e análises de mercado da marca Becel. Em 2016, fundou a 3Marias, uma startup com o intuito de contribuir para segurança da mobilidade feminina. Ingressou no Quintessa no final de 2017, sendo responsável pela busca e pré-seleção de negócios, bem como pela comunicação da aceleradora à época da realização desta pesquisa.

- Maércio Diogo: é formado em Economia pela Universidade Estadual Paulista (UNESP). Desde fevereiro de 2017 atua no Quintessa como gestor de projetos, sendo responsável por conduzir as acelerações dos negócios, auxiliando os empreendedores na estruturação e estratégia de negócios sociais.

Em complemento aos nossos estudos, também entrevistamos uma integrante do grupo de mentores do Quintessa:

- Luciana Branco: jornalista formada pela Pontifícia Universidade Católica de São Paulo (PUC-SP). Em 2004, fundou o escritório de relações públicas Luciana Branco Comunica, hoje batizado de [EM BRANCO]. Atua no planejamento, criação e execução de planos de comunicação para clientes com foco em cultura.

A análise descritiva das entrevistas com os integrantes do Quintessa, amparada pela pesquisa documental da etapa anterior, buscou identificar suas principais características e iniciativas na área de comunicação, a fim de traçar, na etapa seguinte, de análise dos dados, correlações entre aceleradora e negócios acelerados em termos de políticas e filosofias comunicacionais. Recorremos, para a análise, a um resumo das evidências, à triangulação de dados e ao uso de quadros, a fim de auxiliar o trabalho da pesquisadora.

\subsection{Análise descritiva da comunicação do Quintessa}

Ao ser questionada se o Quintessa possui ou não um setor de comunicação, Thaís Fontoura é enfática: "Longe disso". A comunicação da aceleradora entrou em pauta em 2017, a partir contratação da entrevistada. Com formação em Publicidade e Propaganda, ela se juntaria à equipe formada em sua maioria por administradores para aperfeiçoar as vendas e a comunicação do Quintessa.

Sem um setor de comunicação, as atividades da área são tocadas pelo time de busca e seleção de novos negócios, inicialmente por Anna Aranha, em interface com 
parceiros e atores do ecossistema de negócios sociais, e Thaís Fontoura, na relação com os empreendedores e canais de comunicação do negócio. Em abril de 2019, com a chegada de uma nova funcionária ao time, a publicitária Mariana Vale passa a assumir as atribuições da colega, que agora se dedica exclusivamente à seleção de novos negócios. Com o reforço na equipe, a ideia é passar de uma comunicação mais operacional/executiva para outra mais planejada/estratégica. Um exemplo da falta de planejamento estratégico da comunicação do Quintessa é a proximidade da comemoração dos 10 anos da aceleradora, ainda sem programação definida até a realização deste estudo $^{31}$.

Além da nova contratação, outro investimento em curto prazo na área seria a realização, ainda em 2019, de uma pesquisa de opinião com o objetivo de verificar como o Quintessa é compreendido pelos seus públicos. A pesquisa também iria contemplar públicos potenciais do Quintessa - empreendedores que não são de impacto social - a fim de descobrir seu entendimento sobre esse setor. Na época da entrevista, havia grandes expectativas quanto aos resultados da pesquisa: "É o primeiro grande investimento de comunicação dentro do Quintessa", disse Thaís. Em contato posterior com a entrevistada, a pesquisadora foi informada que o projeto foi cancelado, sem maiores esclarecimentos.

\subsubsection{Públicos}

Segundo Thaís Fontoura, o Quintessa identifica entre seus "públicos estratégicos":

- negócios sociais e seus empreendedores: atuais clientes, negócios que já passaram pela aceleração e podem participar de novos programas em outros estágios ou potenciais clientes, independentemente do segmento em que atuam e em todo o território nacional;

- mentores: voluntários, fazem parte da proposta de valor dos programas de aceleração do Quintessa. São considerados um diferencial em relação a outras aceleradoras do ecossistema de negócios sociais;

\footnotetext{
${ }^{31}$ Por ora, o Quintessa lançou a marca comemorativa dos dez anos da aceleradora e está planejando, junto com a agência [EM BRANCO], a realização de um "evento de impacto", nas palavras de Luciana Branco, programado para acontecer no mês de setembro.
} 
- organizações de apoio ao ecossistema de negócios sociais: são as 30 organizações apresentadas no Guia 2.5, sendo empresas ou associações, em sua maioria sediadas no estado de São Paulo, que atuam no suporte ao desenvolvimento de negócios sociais em diferentes frentes: desenvolvimento pessoal, capacitação e treinamento, espaço físico, conexão com investidores, reconhecimento e divulgação, rede de mentores, rede de empreendedores, desenvolvimento da gestão, investimento e financiamento;

- grandes empresas: o Quintessa busca ampliar parcerias com grandes empresas em programas para seleção de empreendedores e aceleração de novos negócios, buscando desenvolver soluções de inovação e sustentabilidade;

- investidores: os investidores de negócios sociais são estratégicos para o Quintessa, que conta com o programa Sponsorship, pelo qual a aceleradora busca no mercado negócios sociais com grande potencial de crescimento e em estágio de ganhar escala.

Há ainda públicos potenciais e pouco explorados pelo Quintessa, como as startups de tecnologia: "Tem um público lá que a gente quer falar", conta Thaís Fontoura. Ir a eventos como a Campus Party, por exemplo, é uma sinalização do Quintessa para "quebrar a bolha", como explica Thaís, e buscar públicos fora do ecossistema de negócios sociais. Apresentamos no Quadro 4 os públicos apontados pelo Quintessa em classificação proposta por França (2010), que considera os objetivos, as expectativas e o planejamento de comunicação. 
Quadro 4 - Tipos, objetivos, dependência e expectativas de relacionamento do Quintessa com os públicos

\begin{tabular}{|c|c|c|c|c|c|}
\hline Tipo de público & Negócios sociais & Mentores & Grandes empresas & $\begin{array}{l}\text { Organizações do } \\
\text { Guia } 2.5\end{array}$ & Investidores \\
\hline Tipo de relacionamento & $\begin{array}{l}\text { negócios; legal; parcerias } \\
\text { em longo prazo }\end{array}$ & $\begin{array}{l}\text { social; colaboração; } \\
\text { parceria em longo prazo }\end{array}$ & $\begin{array}{l}\text { negócios; legal; parcerias } \\
\text { em longo prazo }\end{array}$ & $\begin{array}{l}\text { parcerias em longo prazo; } \\
\text { social }\end{array}$ & $\begin{array}{l}\text { negócios; legal; parcerias } \\
\text { em longo prazo }\end{array}$ \\
\hline Objetivos do Quintessa & $\begin{array}{l}\text { conseguir mais clientes; } \\
\text { ampliar o impacto }\end{array}$ & $\begin{array}{l}\text { apoio e troca de } \\
\text { conhecimentos }\end{array}$ & $\begin{array}{l}\text { mais parceiros; ampliar o } \\
\text { impacto }\end{array}$ & $\begin{array}{l}\text { troca de pipeline e } \\
\text { conhecimentos }\end{array}$ & $\begin{array}{l}\text { ampliar parcerias em } \\
\text { aceleração e captação }\end{array}$ \\
\hline Nível de dependência & essencial & essencial & essencial & redes de interferência & essencial \\
\hline $\begin{array}{l}\text { Expectativas do } \\
\text { Quintessa }\end{array}$ & $\begin{array}{l}\text { satisfação; confiança; } \\
\text { credibilidade }\end{array}$ & $\begin{array}{l}\text { confiança; dedicação; } \\
\text { comprometimento }\end{array}$ & $\begin{array}{l}\text { satisfação; confiança; } \\
\text { credibilidade }\end{array}$ & $\begin{array}{l}\text { relação duradoura; apoio; } \\
\text { bons contatos }\end{array}$ & credibilidade; recursos \\
\hline Expectativas do público & $\begin{array}{l}\text { bom atendimento; } \\
\text { aperfeiçoamento da gestão }\end{array}$ & $\begin{array}{l}\text { reconhecimento; } \\
\text { realização pessoal e } \\
\text { social; aprendizagem }\end{array}$ & $\begin{array}{l}\text { honestidade; retorno de } \\
\text { investimento (social e } \\
\text { financeiro) }\end{array}$ & apoio; bons contatos & $\begin{array}{l}\text { honestidade; retorno de } \\
\text { investimento (social e } \\
\text { financeiro) }\end{array}$ \\
\hline $\begin{array}{l}\text { Como deve ser planejada } \\
\text { a comunicação }\end{array}$ & $\begin{array}{l}\text { direta; permanente; } \\
\text { promocional; persuasiva; } \\
\text { criativa }\end{array}$ & $\begin{array}{l}\text { direta; informativa; } \\
\text { motivadora; interativa; } \\
\text { transmissora de valores }\end{array}$ & $\begin{array}{l}\text { direta; informativa; } \\
\text { permanente; persuasiva; } \\
\text { criativa; transparente }\end{array}$ & $\begin{array}{l}\text { direta; informativa; de } \\
\text { regularidade planejada; } \\
\text { manifestadora de } \\
\text { parcerias }\end{array}$ & $\begin{array}{l}\text { direta; informativa; } \\
\text { persuasiva; transparente; de } \\
\text { regularidade planejada }\end{array}$ \\
\hline $\begin{array}{l}\text { Instrumentos que podem } \\
\text { ser utilizados }\end{array}$ & $\begin{array}{l}\text { informativos; campanhas; } \\
\text { eventos; parcerias; cursos }\end{array}$ & $\begin{array}{l}\text { contatos diretos; reuniões; } \\
\text { informativos; } \\
\text { confraternizações }\end{array}$ & $\begin{array}{l}\text { contatos diretos; reuniões; } \\
\text { relatórios; projetos; } \\
\text { apresentações }\end{array}$ & $\begin{array}{l}\text { encontros; projetos; } \\
\text { publicações; relatórios; } \\
\text { informativos }\end{array}$ & $\begin{array}{l}\text { contatos diretos; reuniões; } \\
\text { relatórios; projetos; } \\
\text { apresentações }\end{array}$ \\
\hline
\end{tabular}

Fonte: Adaptado de França (2010). 


\subsubsection{Políticas, filosofias e objetivos da comunicação}

Toda a comunicação do Quintessa hoje tem um viés prospectivo: seu principal objetivo é atrair empreendedores e conseguir mais negócios para os programas de aceleração. Outro objetivo, mais recente, é ampliar as parcerias com grandes empresas; porém, nossa entrevistada entende que é algo completamente diferente do que o Quintessa faz hoje em termos de prospecção de clientes: "É uma outra linguagem, uma outra forma de chegar nessas pessoas", explica Thaís Fontoura.

Nesta frente, o Quintessa busca novos parceiros para programas como o Braskem Labs, que visa selecionar e acelerar negócios de inovação social. Outro aspecto ressaltado por Thaís é a necessidade de "unificar" a linguagem do Quintessa, melhorando a comunicação institucional. Já a relação com investidores, que costumava ser mais ativa no Quintessa, hoje é passiva, em muitos casos, por indicação do CIVI-CO.

\subsubsection{Comunicação organizacional}

\subsubsection{Comunicação administrativa e interna}

A comunicação interna tem um tom mais informal: "Ainda é um time pequeno, então é tudo muito próximo", diz Thaís Fontoura. Há reuniões quinzenais com todo o time (busca e seleção e gestão de projetos), e duas vezes por ano são realizados encontros de imersão estratégica, com duração de dois a três dias. No final do ano há uma comemoração com toda a equipe do Quintessa. "Com um time maior, será preciso uma outra estrutura", acredita a entrevistada.

A comunicação com mentores é intermediada pelos gestores de projetos e pela

diretora Gabriela Bonotti. É uma relação interpessoal, por telefone ou pessoalmente, no caso da mentora Luciana Branco. Não há ações de comunicação direcionadas para este público (reconhecidamente de valor para o negócio), exceto quando da sua entrada no Quintessa - quando um teste é aplicado ao mentor para alinhar expectativas - e na celebração de final de ano, na qual os mentores podem conhecer um ao outro. "Eu queria ter mais tempo para conhecer mais mentores", disse Luciana Branco ao avaliar positivamente o evento mais recente com mentores realizado pelo Quintessa. 


\subsubsection{Comunicação institucional}

Thaís Fontoura contou que o Quintessa passou seus primeiros anos "em silêncio", e somente em 2017 ficou clara a necessidade de ampliar a comunicação institucional da aceleradora. Só mais recentemente a aceleradora começou a observar " $a$ força de marca do Quintessa", acredita a entrevistada. Com eventos sempre lotados, ela contou que o empreendimento recebeu a seguinte provocação do parceiro Unibes Cultural: colocar o Quintessa no holofote em vez de só dar projeção ao empreendedor. O resultado direto disso foi a série de eventos Histórias que só o Quintessa Pode Contar.

A aceleradora entende que é uma de suas funções e de todo o ecossistema promover a compreensão pública do que é um negócio social. Uma das iniciativas neste sentido é o diálogo constante com os atores desse ecossistema, sobretudo as organizações citadas no Guia 2.5, em encontros da rede para troca de pipeline e aprendizagem, "o que é muito próprio do Quintessa", contou Thaís Fontoura. São 30 organizações citadas no documento, sendo que há aquelas mais próximas da aceleradora e aquelas que só se manifestam para atualizar contatos.

Um exemplo desta troca de pipeline é o relacionamento com a investidora Vox Capital. A investidora costuma indicar ao Quintessa negócios sociais que a procuram e que têm potencial de investimento, mas que ainda não estão prontos para a captação em termos de gestão e desenvolvimento. "São os melhores leads", conta Thaís, numa relação benéfica a ambas as organizações. Para estimular outras parcerias, o time de busca e seleção do Quintessa, principalmente a diretora Anna Aranha, procura ter, no mínimo, uma reunião por ano com as organizações do Guia 2.5 para identificar possíveis objetivos comuns.

Para ampliar o número de parcerias com grandes empresas, a entrevistada entende que o desafio ainda é compreender qual é a melhor linguagem para se conectar com este público e se relacionar com ele. Hoje, as grandes empresas ainda estão vinculadas a ações sociais de cunho filantrópico, sobretudo as fundações e institutos de responsabilidade social, avalia Thaís Fontoura.

\subsubsection{Comunicação mercadológica}

A comunicação mercadológica é a dimensão comunicacional mais bem estruturada no Quintessa: todas as técnicas e instrumentos de comunicação têm, como 
função principal, trazer novos negócios para a aceleradora, explica a entrevistada. Os objetivos da comunicação mercadológica se dividem em fechar novas vendas dos programas de aceleração e cultivar um relacionamento mais próximo com negócios que tenham potencial de impacto social.

A prospecção de clientes acontece sobretudo de maneira ativa, por e-mail ou telefone. Em menor quantidade, há empreendedores que chegam à aceleradora por indicação e há aqueles que a buscam espontaneamente, ou porque participaram de eventos do Quintessa ou porque seguem a aceleradora nas redes sociais ou viram alguma reportagem na imprensa. Esse "lead passivo", contudo, não é qualificado, avaliou Thaís Fontoura.

A publicitária conta que entre as estratégias em estudo está a possibilidade de adotar ações de inbound marketing. Houve uma tentativa de contratação terceirizada, mas que não foi levada adiante devido à compreensão de que uma agência externa não seria capaz de produzir conteúdo qualificado sobre o que o Quintessa faz e conhece do ecossistema de negócios sociais. "É um projeto que precisa internalizar", acredita a entrevistada.

\subsubsection{Técnicas e instrumentos}

O Quintessa trabalha com as seguintes técnicas e instrumentos de comunicação:

- Guia 2.5: documento elaborado pela aceleradora que concentra informações sobre as organizações que apoiam negócios sociais, podendo ser inclusive concorrentes do Quintessa. É um material de suporte ao empreendedor, em constante atualização no site (http://guiadoisemeio.com.br);

- redes sociais digitais: o Quintessa tem páginas oficiais no Facebook (de 2012, com pouco mais de 8 mil curtidas), no Instagram (de 2018, com pouco mais de 1.400 seguidores) e no LinkedIn (pouco mais de 1.300 seguidores). Sobre este último, enquanto a página institucional é pouco movimentada, os perfis pessoais dos funcionários da aceleradora são bastante ativos, uma vez que a rede funciona como um canal para a prospecção de empreendedores.

Para a comunicação digital, o Quintessa também investe pequenas quantias em adwords e posts patrocinados. Vale a pena mencionar ainda que tanto a página no Facebook (www.facebook.com/InstitutoQuintessa) quanto o perfil no LinkedIn 
(www.linkedin.com/company/instituto-quintessa) ainda apresentam em seu endereço eletrônico o antigo nome da aceleradora, Instituto Quintessa;

- organização de eventos: a aceleradora organiza encontros do setor no auditório do CIVI-CO ou do parceiro Unibes Cultural. É o caso, por exemplo, do evento de relançamento do Guia 2.5 ou de encontros temáticos organizados com a finalidade de atrair novos empreendedores e gerar leads para a prospecção de novos negócios. No ano passado, a aceleradora lançou a série de eventos Histórias que só o Quintessa Pode Contar - um painel com a participação da diretora Anna Aranha e de representantes de negócios acelerados ou parceiros. "A gente não conseguiu ficar sozinho no palco", contou a entrevistada Thaís Fontoura. A série teve três eventos em 2018 e, até o momento em que elaboramos esta dissertação, um evento em 2019;

- vídeo institucional: o vídeo foi lançado pelo Quintessa “depois de anos engavetado". $\mathrm{Na}$ opinião da entrevistada, o vídeo "economiza uma hora de conversa" e ajuda o empreendedor a compreender a proposta de valor da aceleradora. Ainda em 2019, o Quintessa pretende lançar "pílulas” do vídeo, que terá uma versão acessível com o apoio da Hand Talk, um dos negócios acelerados.

- assessoria de imprensa: não há uma assessoria de imprensa propriamente dita; o Quintessa se vale do contato pessoal da diretora Anna Aranha com jornalistas para realizar entrevistas sobre a temática e inserir pautas esporádicas na mídia. Os principais veículos são: Valor Econômico, Folha de S.Paulo, Revista Pequenas Empresas \& Grandes Negócios e portal Notícias de Impacto.

- newsletter: é distribuída por e-mail a cada dois meses para um mailing de 3 mil pessoas, na maioria empreendedores sociais. A newsletter apresenta mentores, novos negócios que estão sendo acelerados pelo Quintessa e depoimentos de negócios em fase final de aceleração. A aceleradora também faz uso de e-mail marketing para divulgar os eventos que organiza. Para isso, conta com a ferramenta de marketing digital RD Station, "que poderia ser melhor planejada”, conta Thaís Fontoura.

\subsubsection{Mensuração e avaliação de resultados}

Segundo a entrevistada Thaís Fontoura, o principal indicador de resultados é comercial, ou seja, a geração de "lead qualificado" ou a entrada de um novo negócio para o portfólio do Quintessa. A aceleradora faz uso do Customer Relationship Management 
(CRM) para verificar quais são os canais mais qualificados para o relacionamento com os empreendedores e, assim, aperfeiçoar a prospecção de novos negócios. Não há indicadores de avaliação da comunicação institucional.

\subsection{Entrevistas com os negócios acelerados (terceira etapa)}

O Quintessa conta hoje com 62 negócios sociais ${ }^{32}$ em seu portfólio; os primeiros negócios apoiados representam 13\% desta cartela de clientes, anteriores ao modelo atual de programas de aceleração. Dos negócios acelerados após esta fase inicial:

- cerca de $60 \%$ foram acelerados na fase de tração, ou seja, quando o objetivo é estruturar a gestão e impulsionar o crescimento;

- outros $19 \%$ foram acelerados na fase de validação, etapa de refinamento do modelo de negócio;

- $3 \%$ foram acelerados nas fases de validação e tração; e

- $3 \%$ foram acelerados na fase de escala;

- $2 \%$ participaram do programa de assessoria para captação de investimentos, o mais recente do Quintessa.

A classificação do estágio do negócio é importante para que o Quintessa possa identificar e investigar mais a fundo as demandas e os desafios do empreendedor. Na validação, por exemplo, o objetivo é consolidar o modelo de negócios, tendo em vista a sua sustentabilidade financeira e o impacto social. Na fase de tração, o negócio está crescendo, mas ainda de forma desordenada, sendo a gestão o foco da atuação do Quintessa.

Não há uma predileção da aceleradora por uma tese de mudança específica, mas educação, saúde e meio ambiente são os segmentos mais representativos no seu portfólio: $27 \%$ são negócios da área de educação; $15 \%$ da área de saúde; e, em meio ambiente, temos a segmentação em agricultura, pecuária e agroindústria (7\%), reciclagem $(6 \%)$ e produtos sustentáveis (3\%) (Gráfico 1).

\footnotetext{
${ }^{32}$ Dados de junho de 2019. De acordo com a primeira edição do Guia 2.5, o Quintessa acelerou 30 negócios sociais de 2009 a 2015.
} 
Gráfico 1 - Classificação dos negócios acelerados pelo Quintessa

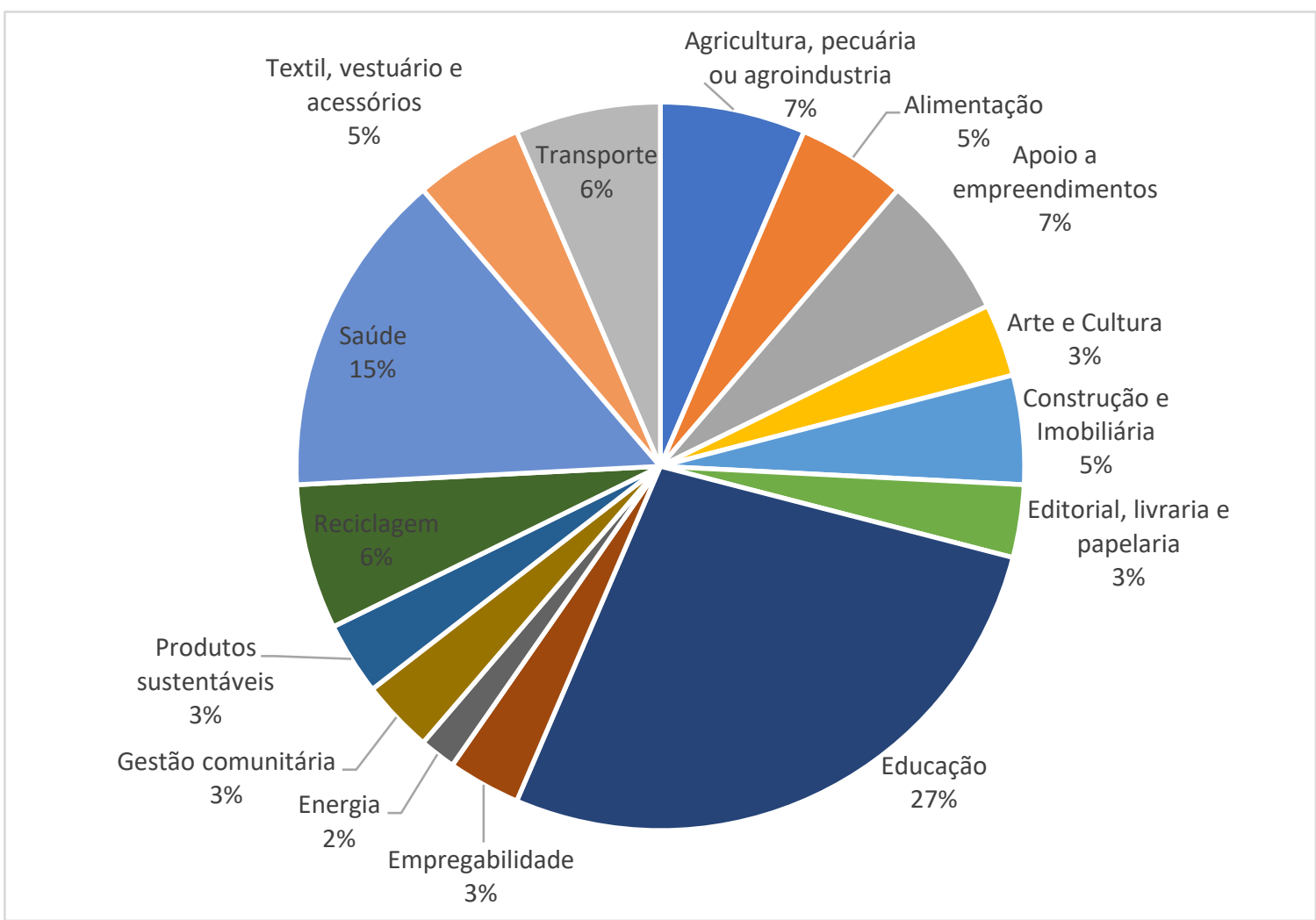

Fonte: Elaborado pela autora.

Sendo o alinhamento aos ODS um dos critérios de seleção do Quintessa, classificamos os negócios acelerados em termos de sua contribuição a eles ${ }^{33}$ (Gráfico 2). Do total de negócios acelerados pelo Quintessa, 29\% vinculam-se ao ODS 4 ("educação de qualidade"), 15\% ao ODS 3 ("boa saúde e bem-estar"), 15\% ao ODS 12 ("consumo e produção responsáveis") e 13\% ao ODS 11 (“cidades e comunidades sustentáveis”). Também são citados os ODS 10 ("redução das desigualdades"), ODS 8 ("emprego digno e crescimento econômico"), ODS 17 (“parcerias em prol das metas"), ODS 2 ("fome zero") e ODS 5 ("igualdade de gênero").

\footnotetext{
${ }^{33}$ Notamos, em alguns casos, negócios identificados com mais de um ODS, optando por aquele que, a critério da pesquisadora, mais se sobressaía à tese de mudança do negócio.
} 
Gráfico 2 - Classificação dos negócios acelerados pelo Quintessa de acordo com os ODS

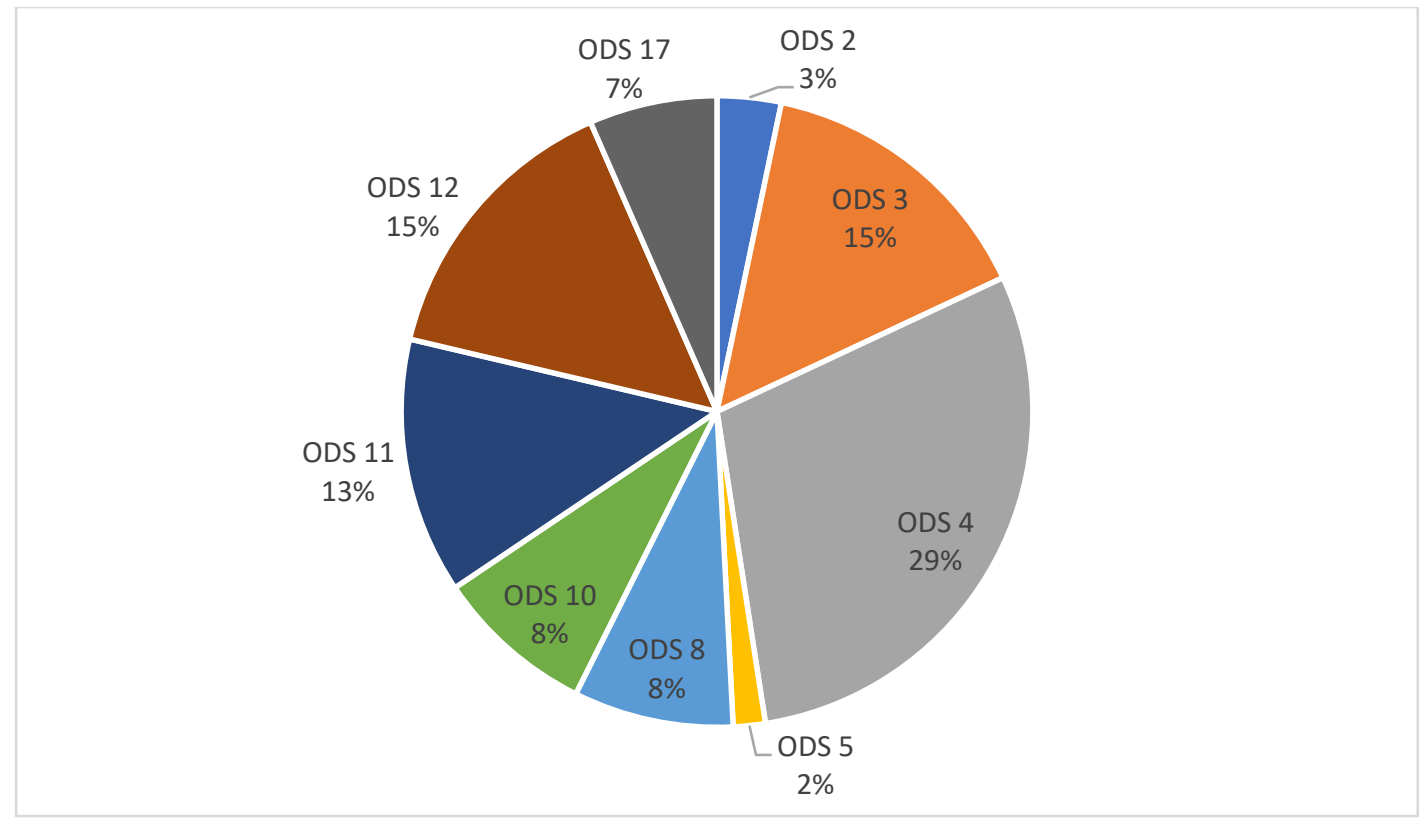

Fonte: Elaborado pela autora.

Quanto à natureza dos negócios acelerados, observamos algumas tendências no portfólio do Quintessa: oferta de soluções de base tecnológica nas áreas da saúde e educação (plataformas de conexão, aplicativos, cursos e material didático on-line), tanto para gestores de saúde e educadores quanto para o consumidor final; lojas on-line em diferentes segmentos e produtos e serviços de baixo custo para a base da pirâmide (em educação, saúde, alimentação e moradia); e produtos sustentáveis. Dois atores do ecossistema de negócios sociais foram acelerados pelo Quintessa: Impact Hub e Sistema B. Do segmento de comunicação e mídia, Catraca Livre, Banca do Bem e a agência CAUSE passaram pelos programas de aceleração.

\subsubsection{Negócios sociais selecionados para o estudo de caso}

Para fins deste estudo de caso, foram escolhidos três negócios acelerados pelo Quintessa: 4YOU2, E-Moving e Banca do Bem. A seguir, uma breve descrição de cada um deles:

- $4 Y O U 2$

Entrevistado: Gustavo Fuga, fundador e presidente 
Fundada em 2012, a 4YOU2 tem a missão de democratizar o ensino de inglês, o que, pela tese de mudança do negócio, aumenta a empregabilidade e, com isso, a renda de jovens e adultos da periferia. Para isso, oferece cursos de inglês high quality/low cost, com professores estrangeiros e material didático on-line. $\mathrm{O}$ cliente em potencial é o jovem/adulto da classe D, de 15 a 40 anos, com idade média entre 20 e 30 anos. A 4YOU2 conta hoje com dez unidades em três estados brasileiros: São Paulo (nos bairros de Capão Redondo, Santana, Ipiranga, Jardim Ângela, Taboão da Serra, Tatuapé e Campo Limpo), Minas Gerais (Patrocínio e Pedro Leopoldo) e Paraíba (João Pessoa), com um total de 66 funcionários. O negócio também conta com uma linha de cursos In Company, para empresas que queiram oferecer cursos de inglês para seus funcionários. O negócio passou pela aceleração do Quintessa em 2013, à época gratuito, num processo que durou quase dois anos.

\section{- Banca do Bem}

Entrevistado: Rodrigo Pipponzi, sócio-fundador da Banca do Bem e diretor-executivo da Editora MOL

A proposta de negócio da Banca do Bem, ainda em fase de validação, é ser um marketplace de produtos conscientes, com a curadoria da Editora MOL, autodeclarada uma editora de impacto social. Desde 2015, a Banca funciona como um e-commerce da editora: a cada livro, revista ou calendário vendido pela Banca do Bem, parte do dinheiro é revertido para instituições sociais ligadas a educação, alimentação, mobilidade, saúde, sustentabilidade ou turismo sustentável. Entre as instituições apoiadas estão: Grupo de Apoio ao Adolescente e à Criança com Câncer (GRAACC), Associação de Assistência à Criança Deficiente (AACD), Instituto Ayrton Senna, Vá de Bike, Todos pela Educação, entre outros. É possível tornar-se assinante das publicações do grupo ou adquirir produtos avulsos pela internet. A Banca do Bem está sendo estruturada para funcionar como uma empresa, tendo a Editora MOL como sócia majoritária. A equipe ainda é pequena: seis pessoas. A Banca do Bem foi um dos negócios acelerados pelo Quintessa entre os meses de março e outubro de 2018.

\section{- E-Moving}

Entrevistado: Gabriel Arcon, CEO e cofundador

Fundada em 2015, a E-Moving oferece o serviço de aluguel de bicicletas elétricas door to door para curtas e médias distâncias na cidade de São Paulo, contribuindo para a 
mobilidade urbana, a redução de gastos do usuário com transporte e a redução de emissão de poluentes no meio ambiente. Oferece duas modalidades de aluguel de bicicletas: Try (quinzenal) e Go (mensal). Atualmente, são alugadas pouco mais de 800 bicicletas na capital para pessoas físicas, entregadores e empresas que queiram oferecer esta possibilidade de locomoção pela cidade aos seus funcionários. Com uma equipe de 36 funcionários, conta com uma montadora de bicicletas, uma loja física na Vila Olímpia e um e-commerce de bicicletas elétricas. A E-Moving foi acelerada pelo Quintessa por cerca de um ano, concluído em maio de 2018.

As entrevistas foram realizadas pessoalmente, no caso da E-Moving, e por telefone, no caso da Banca do Bem e da 4YOU2. Com duração média de 40 minutos, seguiram roteiro semiestruturado em blocos temáticos, que incluiu: história de vida profissional, histórico e tese de mudança do negócio, avaliação dos programas de aceleração, estratégias de comunicação do negócio ${ }^{34}$, avaliação da comunicação do negócio, negócios sociais e sustentabilidade e desafios para o setor.

Os negócios acelerados foram escolhidos de forma não aleatória, considerando alguns critérios julgados importantes pela investigadora para a interpretação e análise qualitativa. As organizações selecionadas puderam trazer diferentes pontos de vista sobre os programas de aceleração do Quintessa e sobre o processo de comunicação em negócios sociais. Dos três negócios, dois foram acelerados na fase de tração e um na fase de validação. Os três negócios são de segmentos diferentes: educação, transporte/mobilidade urbana e editorial/mídia. As práticas discursivas também exploram valores diferentes para seus clientes e públicos: a 4YOU2 é um negócio para a base da pirâmide, com foco em preço com qualidade; a E-Moving integra um movimento de sustentabilidade no meio urbano; e a Banca do Bem atua no engajamento dos públicos em causas sociais.

Quanto aos empreendedores, alguns eram mais experientes à época da aceleração, caso da Banca do Bem, e outros, mais iniciantes, caso de Gustavo Fuga, da 4YOU2. Entre os negócios escolhidos, a E-Moving não conhecia o ecossistema de negócios sociais até ser prospectado pelo Quintessa para os programas de aceleração; os outros dois empreendimentos já estavam mais envolvidos neste setor. Quanto à maturidade do negócio, a 4YOU2 tem 7 anos, a E-Moving, 4 anos, e a Banca do Bem, enquanto negócio próprio, menos de 1 ano.

\footnotetext{
${ }^{34}$ Os objetivos do trabalho foram explicados brevemente para os entrevistados, bem como a concepção de comunicação integrada adotada para fins deste estudo.
} 
Visando embasar a elaboração do roteiro de entrevistas (Apêndice C), foram observados os seguintes pontos:

- se a comunicação possuía valor estratégico nos negócios sociais;

- se a sustentabilidade é um fator estratégico dos negócios sociais;

- se há diferenças de abordagem para a comunicação dependendo do estágio do negócio;

- práticas, instrumentos e técnicas comunicacionais dos negócios sociais acelerados; e

- se são identificadas diferenças entre a comunicação de um negócio tradicional em relação a um negócio social.

\subsection{Análise de conteúdo e interpretação dos dados}

Seguimos, para fins de avaliação e interpretação de todas as entrevistas em profundidade, uma estratégia de análise geral, nos termos propostos por Yin (2001), a partir de pressupostos teóricos que levaram ao estudo de caso e que foram explorados nos capítulos anteriores desta dissertação e, ainda, em conformidade com as questões e objetivos de pesquisa, conforme quadro-síntese do método (Quadro 5). De acordo com Yin (2011, p. 133) "o objetivo final disso é tratar as evidências de uma maneira justa, produzir conclusões analíticas irrefutáveis e eliminar interpretações alternativas".

Para fins deste estudo, optamos pela técnica de análise de conteúdo, tendo como referência principal Bardin (2002), com o objetivo de inferir hipóteses baseadas nas evidências discursivas coletadas em relação ao seu contexto social de forma clara, objetiva e crítica. $\mathrm{O}$ tratamento das entrevistas a partir da análise de conteúdo conduziu à produção de categorias sintéticas relacionadas a cada fator de análise. A investigação das evidências se fundamentou em conceitos e proposições teóricas e em dois modelos específicos para a condução da análise: adequação ao padrão e construção da explanação (BARDIN, 2002). As estratégias de análise buscaram ser condizentes com o objetivo, o problema e as finalidades da pesquisa, priorizando o cruzamento dos dados com a sustentação teórica.

Desse modo, a análise intercala dados e citações dos entrevistados com as referências para demonstrar a conexão entre teoria e evidência empírica. Para auxiliar a análise, utilizamos recursos como a triangulação de dados e elaboração de quadros. Em síntese, o método de análise de conteúdo foi organizado nas seguintes fases: 
a) leitura geral do material coletado (entrevistas e documentos);

b) formulação de categorias de análise, com base no quadro de referências teóricas, questões de pesquisa e indicações trazidas da leitura geral;

c) decupagem das entrevistas;

d) agrupamento progressivo das categorias em iniciais, intermediárias e finais; e

e) inferência e interpretação dos dados, com base no referencial teórico. 
Quadro 5 - Quadro-síntese do método de análise de conteúdo

\begin{tabular}{|c|c|c|c|c|}
\hline Questões de pesquisa & Unidade de análise & Questões do roteiro & Autores & $\begin{array}{l}\text { Análise dos } \\
\text { dados }\end{array}$ \\
\hline $\begin{array}{l}\text { Quais dimensões da comunicação integrada são } \\
\text { identificadas nos negócios sociais? }\end{array}$ & $\begin{array}{l}\text { Todos os entrevistados e } \\
\text { documentação }\end{array}$ & $\mathrm{B} 5, \mathrm{~B} 9, \mathrm{~B} 12, \mathrm{C} 20$ & $\begin{array}{l}\text { Kunsch }(1997,2006,2007 a, 2016) \\
\text { Smith, Gonin e Besharov (2013) }\end{array}$ & $\begin{array}{l}\text { Análise de } \\
\text { conteúdo }\end{array}$ \\
\hline $\begin{array}{l}\text { Quais meios, técnicas e práticas de comunicação são } \\
\text { adotados em negócios sociais e com qual finalidade? }\end{array}$ & $\begin{array}{l}\text { Todos os entrevistados e } \\
\text { documentação }\end{array}$ & B9, B11, C24, C26 & $\begin{array}{l}\text { Kunsch }(1997,2006,2007 a, 2016) \\
\text { França e Ferrari (2008) }\end{array}$ & $\begin{array}{l}\text { Análise de } \\
\text { conteúdo }\end{array}$ \\
\hline $\begin{array}{l}\text { Quais são as diferenças identificadas na comunicação } \\
\text { de um negócio social e de um negócio tradicional? }\end{array}$ & Todos os entrevistados & B9, B23, C15 & $\begin{array}{l}\text { Deetz (2017); Smith, Gonin e Besharov } \\
\text { (2013); Austin, Stevenson e Wei-Skillern } \\
\text { (2012); Comini (2016) }\end{array}$ & $\begin{array}{l}\text { Análise de } \\
\text { conteúdo }\end{array}$ \\
\hline $\begin{array}{l}\text { Nos negócios sociais, a comunicação se configura de } \\
\text { forma planejada e estratégica ou ocasional e } \\
\text { operacional? }\end{array}$ & Todos os entrevistados & B6, B26, C19, C22 & $\begin{array}{l}\text { Kunsch }(1997,2006,2007 a, 2016) \\
\text { Oliveira (2015); Sabbatini (2007) }\end{array}$ & $\begin{array}{l}\text { Análise de } \\
\text { conteúdo }\end{array}$ \\
\hline $\begin{array}{l}\text { Como a comunicação se relaciona com as estratégias de } \\
\text { negócio e a tomada de decisões? }\end{array}$ & Todos os entrevistados & $\begin{array}{l}\mathrm{B} 8, \mathrm{~B} 12, \mathrm{~B} 22, \mathrm{C} 23, \\
\mathrm{C} 25\end{array}$ & $\begin{array}{l}\text { Kunsch (1997, 2006, 2007a, 2016); } \\
\text { Reficco e Vernis (2010); Smith, Gonin e } \\
\text { Besharov (2013) }\end{array}$ & $\begin{array}{l}\text { Análise de } \\
\text { conteúdo }\end{array}$ \\
\hline $\begin{array}{l}\text { Como são abordadas questões ligadas à } \\
\text { sustentabilidade na comunicação dos negócios sociais? }\end{array}$ & $\begin{array}{l}\text { Todos os entrevistados e } \\
\text { documentação }\end{array}$ & $\mathrm{C} 12, \mathrm{C} 25$ & $\begin{array}{l}\text { Kunsch (2009); Smith (2015); Fischer e } \\
\text { Comini (2012) }\end{array}$ & $\begin{array}{l}\text { Análise de } \\
\text { conteúdo }\end{array}$ \\
\hline $\begin{array}{l}\text { Em qual estágio do negócio a comunicação passa a ser } \\
\text { trabalhada do ponto de vista da estratégia de negócio? }\end{array}$ & Todos os entrevistados & B30, B31, B33 & $\begin{array}{l}\text { Kunsch }(1997,2006,2007 a, 2016) \\
\text { Oliveira }(2015)\end{array}$ & $\begin{array}{l}\text { Análise de } \\
\text { conteúdo }\end{array}$ \\
\hline $\begin{array}{l}\text { Qual é a influência dos ODS na comunicação dos } \\
\text { negócios sociais? }\end{array}$ & $\begin{array}{l}\text { Todos os entrevistados e } \\
\text { documentação }\end{array}$ & $\mathrm{C} 10, \mathrm{~B} 34$ & $\begin{array}{l}\text { British Council e Social Enterprise UK } \\
\text { (2015); Programa das Nações Unidas } \\
\text { para o Desenvolvimento (2019) }\end{array}$ & $\begin{array}{l}\text { Análise de } \\
\text { conteúdo }\end{array}$ \\
\hline
\end{tabular}

Fonte: Elaborado pela autora. 


\subsubsection{Categorias de análise}

Optamos neste estudo pela análise temática, estratégia transversal pela qual os dados são organizados em categorias identificadas em função dos conteúdos e na qual "não se têm em conta a dinâmica e a organização, mas a frequência dos temas extraídos do conjunto dos discursos, considerados como dados segmentáveis e comparáveis" (BARDIN, 2002, p. 38)

Para sistematizar a análise dos resultados, optou-se por dividir o diário de campo em categorias, numa "representação simplificada dos dados brutos" (BARDIN, 2002, p. 119). Bardin (2002) avalia que um conjunto de boas categorias deve ter as seguintes qualidades: exclusão mútua, ou seja, um único princípio de classificação deve orientar a sua organização; pertinência, com categorias adaptadas ao material de análise escolhido e ao quadro teórico definido; objetividade; fidedignidade; e produtividade.

Para a autora, "um sistema de categorias é válido se puder ser aplicado com precisão ao conjunto da informação e se for produtivo no plano das inferências" (BARDIN, 2002, p. 55). Para isso, a partir das evidências coletadas, estabelecemos as categorias iniciais de análise, procurando identificar as relações existentes entre elas no estudo de caso.

Por fim, agrupamos progressivamente as categorias iniciais para produzir as categorias intermediárias e, posteriormente, as categorias finais. 


\subsubsection{Quadros-resumo da construção progressiva das categorias de análise}

Quadro 6-Categoria 1: A sustentabilidade dos negócios sociais e os negócios sociais sustentáveis

\begin{tabular}{|c|c|c|c|c|}
\hline Categorias iniciais & Conceito norteador & $\begin{array}{l}\text { Categorias } \\
\text { intermediárias }\end{array}$ & Conceito norteador & Categorias finais \\
\hline $\begin{array}{l}\text { Os conceitos de negócio social e } \\
\text { negócio de impacto }\end{array}$ & $\begin{array}{l}\text { Explora o uso de diferentes terminologias por } \\
\text { pesquisadores e profissionais do setor }\end{array}$ & \multirow{5}{*}{$\begin{array}{l}\text { A sustentabilidade dos } \\
\text { negócios sociais: } \\
\text { desafios do setor }\end{array}$} & \multirow{5}{*}{$\begin{array}{l}\text { A problematização conceitual de } \\
\text { negócios sociais diante do papel } \\
\text { das empresas na solução de } \\
\text { problemas da sociedade, seus } \\
\text { desafios e dificuldades em } \\
\text { compatibilizar objetivos sociais } \\
\text { e financeiros }\end{array}$} & \multirow{10}{*}{$\begin{array}{l}\text { A sustentabilidade } \\
\text { dos negócios sociais } \\
\text { e os negócios } \\
\text { sociais sustentáveis }\end{array}$} \\
\hline O papel das empresas & $\begin{array}{l}\text { Discute a contribuição e responsabilidade das } \\
\text { empresas para a solução dos problemas sociais }\end{array}$ & & & \\
\hline $\begin{array}{l}\text { Objetivos financeiros e objetivos } \\
\text { sociais }\end{array}$ & $\begin{array}{l}\text { Salienta a compatibilidade entre os objetivos sociais } \\
\text { e financeiros dos negócios }\end{array}$ & & & \\
\hline $\begin{array}{l}\text { Fortalecimento do ecossistema de } \\
\text { negócios sociais }\end{array}$ & $\begin{array}{l}\text { Discute o potencial de crescimento dos negócios } \\
\text { sociais }\end{array}$ & & & \\
\hline $\begin{array}{l}\text { Desafios para o empreendedor de } \\
\text { um negócio social }\end{array}$ & $\begin{array}{l}\text { Enumera dificuldades do empreendedor para ter e } \\
\text { manter um negócio social }\end{array}$ & & & \\
\hline $\begin{array}{l}\text { Objetivos de Desenvolvimento } \\
\text { Sustentável (ODS) }\end{array}$ & Discute a adoção dos ODS pelos negócios sociais & \multirow{5}{*}{$\begin{array}{l}\text { Negócios sociais são } \\
\text { negócios sustentáveis? }\end{array}$} & \multirow{5}{*}{$\begin{array}{l}\text { A sustentabilidade enquanto } \\
\text { valor estratégico dos negócios } \\
\text { tradicionais e sociais e a } \\
\text { constituição de cadeias } \\
\text { produtivas mais sustentáveis, } \\
\text { tendo como diretrizes os ODS }\end{array}$} & \\
\hline Comunicação e sustentabilidade & $\begin{array}{l}\text { Explora a comunicação da sustentabilidade e para a } \\
\text { sustentabilidade em negócios sociais }\end{array}$ & & & \\
\hline Sustentabilidade e negócios sociais & $\begin{array}{l}\text { Discute a sustentabilidade nos diferentes segmentos } \\
\text { de negócios sociais }\end{array}$ & & & \\
\hline $\begin{array}{l}\text { Valor estratégico da } \\
\text { sustentabilidade }\end{array}$ & $\begin{array}{l}\text { Problematiza a sustentabilidade enquanto valor na } \\
\text { estratégia de comunicação dos negócios sociais }\end{array}$ & & & \\
\hline $\begin{array}{l}\text { Cadeia de produção e negócios } \\
\text { sociais }\end{array}$ & $\begin{array}{l}\text { Discute a participação dos negócios sociais em } \\
\text { cadeias de produção sustentáveis }\end{array}$ & & & \\
\hline
\end{tabular}

Fonte: Elaborado pela autora. 
Quadro 7 - Categoria 2: A comunicação na aceleração de negócios sociais

\begin{tabular}{|c|c|c|c|c|}
\hline Categorias iniciais & Conceito norteador & Categorias intermediárias & Conceito norteador & Categorias finais \\
\hline O empreendedor social & $\begin{array}{l}\text { Explora a figura do empreendedor no negócio } \\
\text { social }\end{array}$ & \multirow{4}{*}{$\begin{array}{l}\text { Comunicação e } \\
\text { empreendedorismo social }\end{array}$} & \multirow{4}{*}{$\begin{array}{l}\text { A comunicação com os } \\
\text { empreendedores sociais na } \\
\text { prospecção, construção da } \\
\text { solução e avaliação de resultados } \\
\text { de programas de aceleração de } \\
\text { negócios sociais }\end{array}$} & \multirow{8}{*}{$\begin{array}{l}\text { A comunicação na } \\
\text { aceleração de } \\
\text { negócios sociais }\end{array}$} \\
\hline $\begin{array}{l}\text { A comunicação com o potencial } \\
\text { empreendedor a ser acelerado }\end{array}$ & $\begin{array}{l}\text { Evidencia as estratégias de prospecção e busca } \\
\text { por novos negócios sociais para os programas } \\
\text { de aceleração }\end{array}$ & & & \\
\hline $\begin{array}{l}\text { A comunicação com o } \\
\text { empreendedor acelerado }\end{array}$ & $\begin{array}{l}\text { Discute o relacionamento entre empreendedor } \\
\text { e aceleradora após os programas de aceleração }\end{array}$ & & & \\
\hline $\begin{array}{l}\text { A comunicação com o } \\
\text { empreendedor durante a aceleração }\end{array}$ & $\begin{array}{l}\text { Ressalta as trocas comunicativas entre } \\
\text { empreendedor, gestor e mentor durante os } \\
\text { programas de aceleração }\end{array}$ & & & \\
\hline $\begin{array}{l}\text { A comunicação para a aceleração } \\
\text { de um negócio social }\end{array}$ & $\begin{array}{l}\text { Explora a abordagem da comunicação durante } \\
\text { o processo de aceleração de um negócio social }\end{array}$ & \multirow{4}{*}{$\begin{array}{l}\text { Comunicação e a aceleração } \\
\text { de negócios sociais }\end{array}$} & \multirow{4}{*}{$\begin{array}{l}\text { A abordagem do processo de } \\
\text { comunicação em negócios } \\
\text { sociais para diferentes estágios } \\
\text { de negócios, enquanto política, } \\
\text { filosofia e estratégia para } \\
\text { aceleração dos negócios sociais }\end{array}$} & \\
\hline $\begin{array}{l}\text { A comunicação do negócio social } \\
\text { nos estágios de validação, tração e } \\
\text { escala }\end{array}$ & $\begin{array}{l}\text { Discute a comunicação nos diferentes estágios } \\
\text { de um negócio social }\end{array}$ & & & \\
\hline $\begin{array}{l}\text { Avaliação dos programas de } \\
\text { aceleração }\end{array}$ & $\begin{array}{l}\text { Apresenta a avaliação dos empreendedores } \\
\text { quanto aos programas de aceleração }\end{array}$ & & & \\
\hline O mentor & $\begin{array}{l}\text { Discute a figura do mentor nos programas de } \\
\text { aceleração }\end{array}$ & & & \\
\hline
\end{tabular}

Fonte: Elaborado pela autora. 
Quadro 8 - Categoria 3: A filosofia da comunicação integrada em negócios sociais

Categorias iniciais

Comunicação e ecossistema de negócios sociais

A relação dos negócios sociais com o ecossistema

\section{Públicos}

A comunicação com

investidores

A comunicação com grandes empresas

A relação da aceleradora com o ecossistema de negócios sociais

A comunicação institucional de um negócio social

A comunicação do produto ou

serviço de um negócio social

A comunicação com o cliente final e com a empresa

Comunicação administrativa

\section{Comunicação interna}

A comunicação do negócio social e do negócio tradicional

Comunicação estratégica, tática e operacional

\section{Conceito norteador}

Evidencia a comunicação dos atores sociais do

ecossistema de negócios sociais

Discute a relação de negócios sociais com o ecossistema

Públicos dos negócios sociais

Evidencia a comunicação entre aceleradora, negócios

sociais e investidores

Discute a comunicação da aceleradora com grandes

empresas para o desenvolvimento de soluções de

impacto social

Discute a relação entre aceleradora e ecossistema de negócios sociais e o macroambiente

Discute a comunicação de missão, visão e valores organizacionais de negócios sociais

Explora as estratégias de comunicação de produtos e serviços para atuais e potenciais clientes

Ressalta as formas de comunicação com clientes finais (B2C) e corporativos (B2B)

Investiga a comunicação em fluxos e processos produtivos dos negócios sociais

Discute os efeitos da comunicação de um negócio com propósito para as equipes do negócio social

Pontua as diferenças identificadas na comunicação de um negócio social e de um negócio tradicional

Indica quais os tipos de comunicação praticados em negócios sociais
Públicos e o ecossistema

de negócios sociais

\section{Categorias intermediárias \\ Conceito norteador}

Categorias finais

relacionamento entre os públicos do ecossistema de negócios sociais, grandes

empresas e empreendedores sociais, tendo em vista solução de problemas sociais

A filosofia da comunicação integrada em negócios sociais

As diferentes dimensões da comunicação dos negócios sociais - administrativa, interna, institucional e mercadológica - numa perspectiva integrada 
Quadro 8-Conclusão

\begin{tabular}{|c|c|c|c|c|}
\hline Categorias iniciais & Conceito norteador & Categorias intermediárias & Conceito norteador & Categorias finais \\
\hline Planejamento de comunicação & $\begin{array}{l}\text { Discute o nível de planejamento das ações de } \\
\text { comunicação }\end{array}$ & \multirow{8}{*}{$\begin{array}{l}\text { Políticas e estratégias de } \\
\text { comunicação }\end{array}$} & \multirow{8}{*}{$\begin{array}{l}\text { A análise da comunicação } \\
\text { quanto a objetivos, } \\
\text { discursos, políticas, } \\
\text { estratégias, planejamento, } \\
\text { investimentos e indicadores } \\
\text { de avaliação em negócios } \\
\text { sociais }\end{array}$} & \\
\hline $\begin{array}{l}\text { Práticas discursivas dos } \\
\text { negócios sociais }\end{array}$ & $\begin{array}{l}\text { Problematiza a linguagem e o discurso organizacional } \\
\text { na comunicação dos negócios sociais }\end{array}$ & & & \\
\hline $\begin{array}{l}\text { Instrumentos e técnicas de } \\
\text { comunicação }\end{array}$ & $\begin{array}{l}\text { Elenca os instrumentos e técnicas de comunicação } \\
\text { dos negócios sociais }\end{array}$ & & & \\
\hline $\begin{array}{l}\text { Estrutura de comunicação nos } \\
\text { negócios sociais }\end{array}$ & $\begin{array}{l}\text { Detalha a posição da comunicação na estrutura do } \\
\text { negócio social }\end{array}$ & & & \\
\hline Investimento em comunicação & $\begin{array}{l}\text { Indica posição dos empreendedores quanto aos } \\
\text { investimentos em comunicação }\end{array}$ & & & \\
\hline Desafios da comunicação & $\begin{array}{l}\text { Explora os desafios enfrentados pelos } \\
\text { empreendedores na comunicação de negócios sociais }\end{array}$ & & & \\
\hline Avaliação da comunicação & $\begin{array}{l}\text { Evidencia os indicadores de avaliação da } \\
\text { comunicação nos negócios sociais }\end{array}$ & & & \\
\hline $\begin{array}{l}\text { Objetivos da comunicação no } \\
\text { negócio social }\end{array}$ & $\begin{array}{l}\text { Indica os objetivos apontados por empreendedores e } \\
\text { gestores na comunicação do negócio social }\end{array}$ & & & \\
\hline
\end{tabular}

Fonte: Elaborado pela autora. 


\subsubsection{Categoria 1: A sustentabilidade dos negócios sociais e os negócios sociais sustentáveis}

Nesta categoria buscamos compreender aspectos do contexto em que se inserem os negócios sociais. Num primeiro momento, nosso objetivo foi entender os usos e conceitos do termo "negócios sociais" entre os entrevistados do estudo de caso. Observamos, nos dados analisados, que o uso do termo "negócio de impacto social" predomina tanto no Quintessa quanto nos negócios por ele acelerados.

A opção pelo termo "negócios de impacto" demonstra o principal critério de seleção do Quintessa: o impacto social, podendo o negócio ter ou não distribuição de dividendos - quando parcelas do lucro de uma empresa são distribuídos aos seus acionistas como uma forma de remuneração do capital investido por eles. O Quintessa e os negócios analisados adotam a expressão "negócios sociais" no sentido proposto por Yunus (2007), ou seja, para negócios cujos lucros são reinvestidos no próprio empreendimento. Ambos com políticas de distribuição de dividendos, a Editora MOL (da Banca do Bem) e a 4YOU2 também adotam para si o conceito de "negócio do impacto social".

Ao ser perguntado se a E-Moving era ou não um negócio social (ou negócio de impacto), Gabriel Arcon contou que "o Quintessa abriu os nossos olhos para isso". O empreendedor informou ainda que, num primeiro momento, a ideia do negócio surgiu da necessidade dos sócios, que levavam muito tempo no trânsito durante o trajeto de casa para o trabalho: "De uma necessidade, como consequência, descobrimos a questão socioambiental". Gabriel Arcon hoje investe em outras duas empresas que classifica como negócios de impacto social.

Ao se autodenominar aceleradora de negócios de impacto, o Quintessa se diferencia de outras aceleradoras do ecossistema, como a Yunus Brasil e a Bemtevi, que atuam somente com negócios cujos lucros são reinvestidos no próprio empreendimento. Dessa maneira, o Quintessa tem o potencial de atingir mais públicos, mantendo, por assim dizer, "um pé dentro e outro fora" do ecossistema de negócios sociais. Sinaliza, também, certa concordância com a visão de negócios de impacto de Comini, Barki e Aguiar (2013), segundo os quais tais negócios mantêm uma aproximação maior com o mercado tradicional, podendo, inclusive, se tornar grandes empresas após ganhar escala.

A expressão "negócios de impacto" é recorrente na documentação produzida pelo ecossistema de negócios sociais e analisada nesta pesquisa (DUMONT et al., 2016; O RETRATO..., 2019), na contramão dos estudos dos pesquisadores brasileiros 
consultados, que preferem a expressão "negócios sociais", independentemente da distribuição de lucro, num claro descompasso entre academia e mercado. Comum a ambos é a expressão "empreendedorismo social", adotada com diferentes usos e intencionalidades na documentação consultada e por diferentes atores sociais e organizações, fenômeno semelhante ao observado por Baldissera (2009) em seus estudos sobre sustentabilidade.

Os "negócios de impacto" seriam, assim, mais uma variante a ser considerada na escala de negócios híbridos (ALTER, 2007); o uso da expressão pelo ecossistema de negócios sociais, contudo, pode tornar o conceito ainda mais confuso. Duas questões são centrais: em primeiro lugar, a expressão "negócios de impacto" tem um problema semântico, já que qualquer negócio, seja ele social ou não, tem algum impacto na sociedade, podendo ser positivo ou negativo; em segundo lugar, a dificuldade de definir indicadores e mensurar o impacto dos negócios sociais (OLIVEIRA FILHO; KIYAMA; COMINI, 2013) apresenta um outro complicador para o uso da expressão - uma autodenominação que, na prática, não é apropriadamente medida e avaliada.

Para a entrevistada Thaís Fontoura, o conceito de negócios de impacto ainda é muito "difuso" para o mercado, sendo associado às ações filantrópicas e às organizações da sociedade civil. A entrevistada também ressalta que o tema precisa ser mais bem trabalhado no mercado e na opinião pública e que "nós [o ecossistema] somos os que mais conhecemos o tema, então é certo que a gente fale sobre ele". Para a mentora Luciana Branco, a dificuldade na compreensão do conceito terá seus efeitos sentidos na comunicação dos negócios: "Há uma complexidade grande dos negócios de impacto para comunicar, até porque os interlocutores ainda não estão entendendo essa conciliação do business com o social". A opinião das entrevistadas é um indicativo da necessidade de uma social business literacy entre os públicos dos negócios sociais.

Os negócios sociais são resultado direto de um contexto social, cultural e político que ressignificou o papel das empresas na solução de problemas sociais. Tal entendimento está na gênese do Quintessa e é central na tese de mudança da aceleradora, que destaca a possível contribuição do empreendedorismo social e das empresas para transformar a realidade social do país. Questão sensível aos negócios sociais, o impacto social do Quintessa é inferido (mas não quantificado) pelo impacto alcançado pelos negócios acelerados: "quanto mais os negócios impactam, mais o Quintessa impacta", resume Thaís Fontoura. 
A tese de mudança do Quintessa alinha-se à modificação de perspectiva quanto à noção de desenvolvimento, discutida por Fischer e Comini (2012), e do exercício de novos papéis pelos negócios na contemporaneidade (KUNSCH, 2009), dando novo sentido à noção de empreendedorismo, antes vinculado somente a aspectos financeiros. “O que o CEO precisa entender é que se ele não mudar, o business pode acabar. Mas se ele mudar, o business pode ser muito mais lucrativo", é a opinião da mentora Luciana Branco, que acredita na necessidade de uma mudança de consciência das lideranças, de modo que sejam repensados todos os processos organizacionais.

Ao falar sobre a oferta do seu produto para pessoas jurídicas, o empreendedor Gabriel Arcon afirma que as empresas são corresponsáveis, junto com os órgãos públicos, por promover mudanças positivas na sociedade: "O que a sua empresa faz pela mobilidade urbana? Oferece vale estacionamento?", disse o CEO da E-Moving. Para o empreendedor, "as empresas têm o papel de persuadir, educar e incentivar os seus colaboradores a utilizar formas alternativas de deslocamento", ao citar que uma empresa pode gerar impacto social positivo ao tomar medidas simples - por exemplo, ao oferecer a seus funcionários a possibilidade de ir de bicicleta para o trabalho ao invés de dirigir um carro corporativo.

Mudar o modelo de negócios de uma grande empresa, contudo, não é trivial, como explica o gestor de projetos Maércio Diogo. É como "manobrar um transatlântico", ao contrário de uma startup, em que as mudanças são mais fáceis de ser operacionalizadas. O impacto, porém, é muito maior. Maércio entende que os negócios sociais podem contribuir para que as grandes empresas agreguem os esforços de responsabilidade social à sua estrutura de negócio, criando uma linha de valor compartilhada ao oferecer soluções melhores, mais sustentáveis e mais baratas para as cadeias produtivas, ajustadas "a partir da realidade do cliente", explicou o entrevistado.

\subsubsection{Sustentabilidade e negócios sociais}

O gestor de projetos Maércio Diogo acredita que o valor atribuído à sustentabilidade seguirá os critérios de escolha do cliente, numa avaliação entre custo e benefício dos produtos e serviços oferecidos pelos negócios sociais. Quando o cliente é uma grande empresa, a sustentabilidade assume valor estratégico se ligada à cadeia de produção ou à aquisição de negócios sociais inovadores por negócios maiores, explica o entrevistado. Nestes cenários, os negócios sociais ganham rápida escala. Nota-se, aqui, a 
noção de sustentabilidade ligada, sobretudo, a aspectos do ciclo "de vida de produtos, cadeias produtivas, serviços e funções dos negócios na sociedade” (SMITH, 2015, p. 39). Já o cliente final pode ou não ver valor em um negócio social sustentável: "Ser sustentável é suficiente para ser um diferencial? Dependendo do cliente, não”, acredita Maércio Diogo. Para clientes da base da pirâmide, por exemplo, o sustentável também precisa ser mais barato, explica Maércio: "Alguns negócios precisaram entender que precisavam ser mais baratos para vender mais".

Na 4YOU2, escola de inglês para a população de baixa renda, a sustentabilidade não é um tema presente na comunicação, diferentemente dos outros dois negócios analisados. "A gente sempre fala que é uma empresa sustentável", diz Gabriel Arcon, da E-Moving. Ele explica ainda que a sustentabilidade "é uma consequência do negócio. Não é algo forçado. Ser sustentável está no nosso sangue. Não vou colocar bike em combustão na rua, por exemplo". Observamos que, seja para o cliente final, seja para a grande empresa, a discussão sobre o valor estratégico da sustentabilidade passa necessariamente por uma compreensão mais abrangente dos sentidos e significados da sustentabilidade (BALDISSERA, 2009).

A Editora MOL associa a sustentabilidade à certificação $\mathrm{B}$, ainda que o próprio B-Lab diferencie a certificação de outras práticas de sustentabilidade e responsabilidade social (RODRIGUES, 2016). Segundo Rodrigo Pipponzi, a certificação B é muito exigente, abrangendo aspectos ligados à escolha dos parceiros, ações para o bem-estar dos funcionários e cultura organizacional. Para Rodrigues (2016), a grande diferença entre uma empresa B e uma empresa com práticas de responsabilidade social é a mensuração de resultados e prestação de contas, uma exigência da B-Lab - "porém, não é possível afirmar que a empresa B representa um novo tipo de organização ou um novo setor na economia, como sugerem suas mensagens" (RODRIGUES, 2016, p. 196).

Desde 2014, a 4YOU2 também é uma empresa B, “um reconhecimento do nosso compromisso com a transparência, responsabilidade e o bem-estar social”, conforme citado no site da organização (4YOU2..., c2019). A Banca do Bem também está sendo estruturada para ser uma empresa B, segundo Rodrigo Pipponzi. Ao ser perguntado se a certificação agrega ao negócio, o empreendedor responde: "Sim, cada vez mais. Tô até impressionado com isso. Como todo mundo tá começando a conhecer isso". A visão de Rodrigo Pipponzi quanto à certificação $\mathrm{B}$ demonstra uma preocupação do mercado quanto à maior cobrança sobre as organizações por atitudes éticas e responsáveis (KUNSCH, 2007a) e corrobora a perspectiva de Rodrigues (2016) sobre a iniciativa: 
empresas B visam, com a certificação, ganhar visibilidade no mercado e atrair consumidores e investidores.

Observamos, nos empreendimentos acelerados pelo Quintessa, a preocupação com boas práticas corporativas; dois dos três negócios analisados são empresas B (4YOU2 e Editora MOL), porém, sem a dimensão ambiental vinculada à estratégia de negócios, não são autodeclaradas empresas sustentáveis. O único negócio autodeclarado sustentável, a E-Moving, é aquele que, apesar de não ser certificado, possui uma dimensão ambiental ligada ao impacto social do negócio: a redução da emissão de $\mathrm{CO}_{2}$.

O Quintessa não é focado em negócios sustentáveis, mas uma parcela do seu portfólio adota tais práticas, sobretudo nos eixos de produtos sustentáveis, reciclagem e uso de recursos naturais. Segundo Thaís Fontoura, o Quintessa está mais interessado no impacto que os negócios podem trazer à sociedade. Assim, todos os negócios acelerados pelo Quintessa terão impacto social, sendo alguns sustentáveis e outros não. Serão considerados sustentáveis pela aceleradora os negócios que contemplem os três pilares de Elkington (2001), econômico, ambiental e social, mas se observa pelo seu portfólio o predomínio do pilar social. A entrevistada explica ainda que o negócio que se propõe a ser sustentável (aqueles ligados, sobretudo, à resolução de problemas ambientais) já procura o Quintessa com esse propósito, e a aceleradora irá atuar somente na gestão e desenvolvimento do modelo de negócios. Ou seja, o Quintessa não atribui para si a responsabilidade de tornar o negócio mais sustentável.

Nesse cenário, os ODS se configuram no Quintessa como pressupostos básicos para um primeiro entendimento do negócio social e ajudam a embasar a sua tese de mudança. "É uma das primeiras perguntas" dos programas de aceleração, conta Maércio Diogo, ajudando no alinhamento entre aceleradora e empreendedor, sem, contudo, restringir o negócio a um ou outro ODS. "Não é o melhor direcional, mas é o que temos", avalia Thaís Fontoura. Para o gestor de projetos, os ODS ajudam a orientar a discussão, mas não ajudam na solução. Ou seja, os ODS “ajudaram a trazer um norte para institutos empresariais e empresas", mas não são conclusivos sobre a melhor resposta aos problemas sociais, na opinião de Maércio Diogo.

A mentora Luciana Branco aponta outra problemática dos ODS: o desconhecimento de grande parte da população acerca dos objetivos propostos pelas Nações Unidas. Para a jornalista, os ODS são "um ponto de partida maravilhoso para nortear prioridades. [...] Dentro do Quintessa, todo mundo sabe de cor. Os negócios acelerados também. Fora daquele universo, porém, ninguém nunca ouviu falar". Ela 
atribui para si e para os profissionais de comunicação o papel de "furar a bolha para fazer conexões reais", ou seja, fazer com que um número cada vez maior de pessoas compreenda, fale e se engaje em relação aos ODS. "Como a gente faz o pop falar dos ODS? Isso é comunicação de impacto”, afirma a mentora, para quem, sem isso, não será possível transformar a realidade social, apenas obter "aplausos da nossa própria bolha".

O uso dos ODS pelo Quintessa se configura, em nossa análise, como uma tentativa de se ajustar e fazer parte de uma agenda global, em vez de ser compreendido como uma diretriz de trabalho propriamente dita. Isso se verifica, em hipótese, no fato de que os ODS não dialogam de maneira adequada com o pequeno e médio empreendedor (BRITISH COUNCIL; SOCIAL ENTERPRISE UK, 2015), dificultando o vínculo entre os ODS e o trabalho do Quintessa.

A própria aceleradora avalia, contudo, que os ODS são importantes para o diálogo que deseja manter com grandes empresas e investidores, vide, por exemplo, os propósitos e ações da Rede Brasil do Pacto Global (REDE BRASIL DO PACTO GLOBAL; PROGRAMA DAS NAÇÕES UNIDAS PARA O DESENVOLVIMENTO, 2019). Por tais razões, os ODS são mencionados no discurso do Quintessa, mas sem muita força e desvinculados do impacto social gerado pelo empreendimento. Em nossa análise, uma comunicação articulada entre ODS e impacto social poderá contribuir para a formação de alianças intersetoriais (FISCHER, 2012), sobretudo com as grandes empresas, fator estratégico para alavancar o impacto dos negócios sociais (COMINI, 2016).

Para Thaís Fontoura, o termo "sustentabilidade" é habitual em grandes empresas e organizações da sociedade civil, mas pouco utilizado nos negócios sociais, salvo aqueles ligados às temáticas ambientais. $\mathrm{O}$ entendimento da sustentabilidade pela sua dimensão ambiental é notável entre os empreendedores entrevistados. Ao ser perguntado sobre a sustentabilidade na 4YOU2, Gustavo Fuga imediatamente responde: "Ambiental, você diz? Pouco, podemos desenvolver bem mais". Contudo, ele responde afirmativamente quanto aos negócios sociais terem o potencial de incentivar outros negócios a serem mais sustentáveis.

\subsubsection{Por um modelo de negócios sustentável}

Sustentável ou não, ser um negócio social requer especial atenção ao modelo de negócios, a fim de conciliar objetivos financeiros e sociais - é o que revelam os dados 
analisados. O Quintessa é um caso de organização que teve que ajustar seu plano de negócios para conciliar objetivos sociais e sustentabilidade financeira: a aceleradora foi criada como instituto, oferecendo aceleração gratuita aos empreendedores, mas percebeu a necessidade de mudar o negócio para continuar a existir. Hoje, ajuda outros negócios sociais a ter modelos de negócios sustentáveis.

Maércio Diogo explica que, durante a aceleração, os objetivos sociais e financeiros do empreendimento são definidos na validação do plano de negócios. "São processos que correm juntos" e entram em uma das grandes pautas do Quintessa: a estratégia do negócio. Quando perguntado se, em algum momento da aceleração, o negócio perde seu propósito inicial, Maércio responde: “Não necessariamente, mas muda de curso".

A importância do modelo de negócios para conciliar objetivos sociais e financeiros é reforçada pelos entrevistados. Gustavo Fuga, da 4YOU2, não vê dificuldades em conciliar financeiro e social: "Quanto mais o negócio cresce, mais impacto social ele gera", é a explicação dada pelo empreendedor. No caso da Banca do Bem, Rodrigo Pipponzi diz que conciliar objetivos financeiros e sociais é visto como algo natural:

A gente tem indicadores que já levam isso em consideração, para que não haja conflito. O negócio já é montado de uma forma que todos os indicadores convivem. A gente não precisa somar o social no negócio; o negócio depende da geração social. Se não gerar resultado social, a empresa para, não funciona. Os dois modelos andam juntos.

O empreendedor explica ainda que a motivação de compra de um produto na Banca do Bem é social; portanto, quanto mais livros e revistas são vendidos, maior é o impacto social. Contudo, ele observa que é usual ter que renunciar a oportunidades com potencial de gerar lucro, mas que não se encaixam na missão social do negócio.

Em suma, quanto aos objetivos sociais e financeiros, tópico recorrente na literatura sobre negócios sociais, os empreendimentos analisados e o Quintessa têm postura semelhante: conciliar objetivos sociais e financeiros depende, sobretudo, do modo como é estruturado o plano de negócios. O plano deve ser desenvolvido de forma que, quanto mais o negócio lucre, maior impacto social cause. Tal perspectiva se aproxima da noção de "valor compartilhado", de Porter e Kramer (2011), e da proposição de Rodrigues (2016) de posicionar a responsabilidade social na estratégia de negócios.

Os objetivos sociais e financeiros dos negócios investigados podem ser avaliados em termos de uma escala contínua, tal qual proposto por Austin, Stevenson e Wei-Skillern 
(2012). Ao classificarmos 4YOU2, Banca do Bem e E-Moving de acordo com os fatores de finalidade, cadeia de valor, processo decisório e sustentabilidade financeira (COMINI, 2016), observamos que os negócios obedecem a uma lógica social, sobretudo quanto à finalidade (Quadro 9). Em outros critérios, aproximam-se das práticas de mercado. Cabe observar que, para selecionar negócios acelerados, o Quintessa prioriza a finalidade, não os demais critérios. 
Quadro 9 - Classificação de empreendimentos sociais aplicado a E-Moving, 4YOU2 e Banca do Bem

\begin{tabular}{|c|c|c|c|c|c|c|c|}
\hline \multirow{5}{*}{ Finalidade } & Fatores & $\begin{array}{l}\text { Lógica de } \\
\text { mercado }\end{array}$ & Lógica social & $\begin{array}{l}\text { Lógica de } \\
\text { mercado }\end{array}$ & Lógica social & $\begin{array}{l}\text { Lógica de } \\
\text { mercado }\end{array}$ & Lógica social \\
\hline & Objetivo principal & & 4YOU2 & & E-Moving & & Banca do Bem \\
\hline & Oferta & & 4YOU2 & & E-Moving & Banca do Bem & \\
\hline & Intencionalidade & & 4YOU2 & & E-Moving & & Banca do Bem \\
\hline & Escala & 4YOU2 & & E-Moving & & Banca do Bem & \\
\hline \multirow{3}{*}{ Cadeia de valor } & Clientes & & 4YOU2 & E-Moving & & Banca do Bem & \\
\hline & Fornecedores & 4YOU2 & & E-Moving & & & Banca do Bem \\
\hline & Colaboradores & 4YOU2 & & E-Moving & & Banca do Bem & \\
\hline Governança & Processo decisório & 4YOU2 & & E-Moving & & Banca do Bem & \\
\hline \multirow{2}{*}{ Sustentabilidade financeira } & Distribuição de lucro & 4YOU2 & & E-Moving & & Banca do Bem & \\
\hline & Valor econômico & 4YOU2 & & E-Moving & & & Banca do Bem \\
\hline Total & & \multicolumn{2}{|c|}{-2} & \multicolumn{2}{|c|}{-4} & \multicolumn{2}{|c|}{-2} \\
\hline
\end{tabular}

4 YOU2
E-Moving $\bigcirc$ Banca do Bem

$-10 \quad$ Lógica de mercado

Fonte: Adaptado de Comini (2016).

Lógica social 
Não são poucos os desafios de um negócio social - avaliam os entrevistados -, e eles ainda podem variar de acordo com o estágio em que o negócio se encontra. Em empreendimentos em fase de tração, por exemplo, as queixas costumam ser o volume de vendas, conta Thaís Fontoura. Maércio Diogo ressalta a necessidade de os negócios terem um olhar mais analítico para as vendas, a fim de mitigar riscos. É preciso ainda montar equipes mais fortes e complementares, que gerem negócios mais consistentes.

Quando as vendas não são o problema, o olhar se volta para a gestão, ou seja, para a qualidade da entrega - próprio dos negócios em estágio de escala, explica o gestor de projetos do Quintessa. É o caso da 4YOU2, que está em um processo de escala rápida, em que a prioridade é criar uma cultura de time e uma estratégia de vendas robusta para atrair novos alunos, explica Gustavo Fuga. Negócio da base da pirâmide, a 4YOU2 tem o "desafio enorme" de aliar qualidade com preço baixo, o que remete à recomendação do PNUD sobre a necessidade de negócios sociais buscarem aliar tecnologia e impacto social para crescer (PROGRAMA DAS NAÇÕES UNIDAS PARA O DESENVOLVIMENTO; FUNDAÇÃO DOM CABRAL, 2015).

Para a Banca do Bem, o desafio é sair da condição de startup e tornar-se um negócio estruturado. Mais madura, a Editora MOL tem buscado estruturar planejamento, produto, operação e transparência para ganhar escala, o que significa atrair parceiros para grandes mobilizações, aumentando o volume de recursos arrecadados. No caso da E-Moving, Gabriel Arcon deseja expandir suas operações na cidade de São Paulo e em outras médias e grandes cidades brasileiras. Na visão do empreendedor, eles conseguiram provar a tese de mudança e criar "excelentes cases"; é chegada a hora de expandir.

Observamos, pelos dados analisados, que os desafios dos negócios sociais se relacionam diretamente com o impacto que querem gerar, ou seja, descobrir como melhorar o produto ou serviço para conseguir chegar a um impacto social mais relevante.

O fortalecimento do ecossistema de negócios sociais, por sua vez, passa pela capacidade de os empreendimentos explicitarem seu valor na sociedade e, assim, atrair mais investimentos para o setor, acredita o entrevistado Maércio Diogo. Para isso, os negócios precisam gerar mais cases e, assim, inspirar novos negócios. Para Maércio Diogo, "poder testar mais seria bom", já que o nível de risco de um empreendimento é alto. 
Tópico presente nos relatórios produzidos por atores do ecossistema de negócios sociais (O RETRATO..., 2019), a atração de novos investimentos para o setor também é um desafio apontado pelos entrevistados. Gustavo Fuga acredita que é preciso investir mais nos estágios iniciais do negócio, fase de validação do modelo de negócios, uma vez que "passar dessa fase é bem difícil". Destacamos da fala do empreendedor sobre a necessidade de mais apoio nas fases iniciais do negócio o suporte ofertado no Guia 2.5, do Quintessa, que privilegia negócios já mais estruturados - em estágio 5 ou 6. Ou seja, o empreendedor não está conseguindo a ajuda que precisa justamente no momento mais crítico do negócio.

\subsubsection{Categoria 2: A comunicação na aceleração de negócios sociais}

“O empreendedor é um ser solitário", relatou Gabriel Arcon, da E-Moving. "É uma jornada bem dolorida", ressaltou Maércio Diogo. "O empreendedor é um aventureiro. Todos são e precisam ser", acredita a mentora e empreendedora Luciana Branco. "Tem que ter estômago", além de maturidade emocional e financeira, disse Thaís Fontoura, que, na contramão de outros colegas de faculdade, optou inicialmente pelo empreendedorismo em vez de um emprego formal. Esse também é o caso de Gustavo Fuga, que fundou a 4YOU2 aos 18 anos - sem experiências profissionais anteriores, Fuga contou com o auxílio do Quintessa para organizar a gestão do seu negócio.

Gustavo Fuga, Gabriel Arcon e Rodrigo Pipponzi são profissionais já há algum tempo no mercado e, ao longo de suas trajetórias, desenvolveram competências para gerir seus negócios, entre elas, comunicacionais. São convidados com frequência a participar de eventos do ecossistema de negócios sociais e fora dele. Também foram reconhecidos dentro e fora deste ecossistema: em 2015, Fuga recebeu o prêmio Jovem Talento da Viva Idea, uma fundação que apoia o desenvolvimento sustentável na América Latina. Em 2017, a E-Moving ganhou o prêmio da consultoria Ernest \& Young na categoria Emerge, para negócios com

potencial de crescimento. Em 2018, Rodrigo Pipponzi foi eleito empreendedor social do ano no prêmio da Folha de S.Paulo. O Quintessa, por sua vez, tem na figura da diretora Anna Aranha a sua principal porta-voz e interlocutora com outros atores do ecossistema de negócios sociais e do mercado. 
O empreendedor é figura central nos programas de aceleração do Quintessa. Maércio Diogo conta que, em média, "60\% do diálogo é com o empreendedor"; por isso, o perfil desse profissional é um dos critérios adotados na seleção de novos negócios. Mas, acrescenta, às vezes também "é preciso não falar com ele para estruturar o restante do time", revelando que é comum a centralização excessiva do negócio na figura do empreendedor social.

Em nossa análise, envolver o empreendedor nas estratégias de comunicação é fundamental, uma vez que a participação da alta direção é um dos elementos-chave para o sucesso de uma política de comunicação integrada (KUNSCH, 2016). Soma-se a isso, no caso do empreendedor social, a necessidade de desenvolver "a capacidade de construir e manter redes sociais de cooperação mais amplas, uma vez que visa a causas de interesse público" (OLIVEIRA; NADER, 2017, p. 47). Na prática, a mentora Luciana Branco afirmou estimular os empreendedores, nas parcerias, a "pensar grande", com vistas a alcançar maior impacto social.

Em um cenário de escassez de recursos para investimentos em comunicação, o empreendedor é, certamente, o melhor instrumento de comunicação de um negócio social em sua fase inicial. Na ausência dele, outra possibilidade é buscar no time um profissional para desenvolver tais habilidades e competências comunicacionais, sem perder de vista o olhar estratégico para o negócio.

\subsubsection{O primeiro contato com os empreendedores}

Para contatar novos empreendedores sociais, o Quintessa faz a prospecção ativa por telefone e e-mail. Apesar de contar com metas de vendas pré-estabelecidas, segundo a publicitária Thaís Fontoura, não se trata de um setor de vendas, mas de uma área de busca e seleção de novos negócios que contempla uma dimensão de relacionamento com os empreendedores. "A gente nunca fala que é uma área de vendas, mas uma área de seleção", disse Thaís. Outro termo evitado no contato com o empreendedor é o de "aceleradora de impacto social", já desgastado no ecossistema de negócios sociais, como avalia a profissional. Isso porque o empreendedor pode já ter passado por um programa de aceleração ou ter sido convidado a ingressar em outras aceleradoras. 
Trata-se ou não de uma relação de venda? Não fica claro. Avaliamos que a ambiguidade no discurso do Quintessa pode ser mitigada por uma comunicação mercadológica e institucional mais clara, informativa e objetiva. Para além da prospecção de novos clientes, a aceleradora pode se valer, ainda, da oferta de branded content (conteúdo de valor) alinhado à estratégia de negócios (oferta de serviço de qualidade), numa ação articulada e integrada da comunicação institucional e mercadológica, necessária a um mercado competitivo (KUNSCH, 2007a).

A seleção de novos negócios para os programas de aceleração é longa: o Quintessa tem grande preocupação com a pesquisa sobre o empreendimento em potencial, a classificação do estágio do negócio (validação, tração ou escala) e o diagnóstico. A relevância do problema e da solução é um dos principais tópicos de investigação ao selecionar novos negócios. Com o tempo e energia gastos na seleção, poucos empreendimentos desistem depois de acertada a participação nos programas de aceleração, conta Maércio Diogo.

Os empreendedores recém-chegados ao Quintessa relatam dificuldades nas vendas ou falta de organização do negócio, que "cresceu bagunçado", contou Thaís. É comum os empreendedores relatarem problemas de vendas, o que muitas vezes descobrem ser um problema de estratégia, explica o gestor de projetos. Mesmo aqueles que relatam problemas de comunicação, na verdade têm problemas anteriores, ligados à gestão do negócio, avalia a mentora Luciana Branco: “O que eu percebo é que a comunicação às vezes é muito pensada como solução, quando na verdade a solução é a gestão, entendeu? A comunicação é consequência". As falas do gestor e da mentora do Quintessa revelam uma visão de comunicação ligada a aspectos operacionais e táticos, que não contempla as conexões possíveis entre comunicação e estratégia do negócio; para os entrevistados, a comunicação deve ser abordada em um momento posterior à elaboração do plano de negócios.

Gustavo Fuga, por exemplo, tinha certeza de ter um bom serviço, mas, por inexperiência com o empreendedorismo, buscou o Quintessa para ajudar a estruturar a 4YOU2. A Banca do Bem vivia um momento "confuso", disse Rodrigo Pipponzi: ecommerce em crescimento, estratégia equivocada, precificação errada, vontade de ampliar os produtos vendidos. No caso da E-Moving, o Quintessa procurou o empreendedor Gabriel Arcon num momento em que o negócio estava próximo de obter aporte de investimento externo para crescer - fase de reavaliar o planejamento estratégico da empresa. 


\subsubsection{Durante a aceleração}

O Quintessa destaca a personalização dos programas de aceleração em função das demandas do empreendedor, que " $n$ a operação não muda tanto, mas no olhar para o negócio", contou o entrevistado Maércio Diogo. A proposta dos programas de aceleração do Quintessa contempla um indicador de estudo da Pipe Social (O RETRATO..., 2019) quanto à necessidade de programas mais customizados e adequados às necessidades específicas dos empreendedores sociais. Assim, em vez de sugerir um conjunto de boas práticas, a aceleradora busca "criar um espaço de confiança para os empreendedores abrirem os seus problemas", com transparência, olhar crítico e bons conteúdos, explica Maércio Diogo. Ainda sobre a aceleração, o gestor de projetos ressalta que:

A não ser que seja uma premissa, a aceleradora não apresenta uma boa prática se não tiver uma necessidade latente ali [...]. Às vezes, a gestão de pessoas não é ideal (em termos de boas práticas), mas está funcionando. Ou outras coisas são prioritárias. Isso ajuda a empresa a ter foco.

Quando a demanda é relevante para o negócio, a questão é trabalhada junto com os mentores em "duas ou três reuniões", contou Thaís Fontoura. Luciana Branco, por exemplo, é a principal mentora do Quintessa para assuntos ligados à comunicação institucional. A jornalista se juntou ao quadro de mentores da aceleradora em 2017, por convite de Thaís Fontoura, da qual foi mentora à época que a publicitária atuava no negócio social 3Marias.

Sobre as suas expectativas em relação à aceleração, Gustavo Fuga contou que, "como o produto se vendia sozinho, a gente tava mais preocupado com a qualidade da entrega". Outro ponto trabalhado com o Quintessa foi o posicionamento da 4YOU2: "É uma escola? É um projeto social?" foram exemplos de questões discutidas durante a aceleração. Enquanto a proposta de valor para o negócio era clara, a discussão foi centrada no posicionamento da 4 YOU2 perante os alunos. Já a aceleração da E-Moving aconteceu por um período de um ano, em que um gestor do Quintessa ia até o negócio de duas a três vezes por semana; além disso, a empresa tinha reuniões quinzenais com um mentor. "O Quintessa que procurou a gente [...]. Eles também estavam começando a se estruturar; tinham umas cinco empresas acelerando", conta Gabriel Arcon. 
Rodrigo Pipponzi trabalhou com Maércio na aceleração da Banca do Bem em 2018. No início, conta o empreendedor, realizou-se um trabalho investigativo, para entender o negócio e tirar dúvidas. O contato com o gestor era frequente, além de seis a sete reuniões e um workshop com o mentor Reynaldo Naves, fundador e sócio da consultoria Biz2Biz: Transformando Negócios. O empreendedor contou que todos os funcionários da Banca do Bem e os sócios da Editora MOL estiveram envolvidos na construção do plano de negócios, num processo que classificou como "imersivo".

Maércio Diogo explica que o Quintessa prioriza nos programas de aceleração "o que mais dói no acelerado", normalmente tópicos ligados às vendas, gestão e equipe. Para além disso, ou o tema é apontado pela aceleradora no diagnóstico ou é uma demanda específica do negócio. Nesses casos, "a gente acessa a rede conforme as demandas do empreendedor", e o tópico é trabalhado com um dos mentores. Caso contrário, "não adianta forçar a pauta", conta Maércio, ressaltando que o empreendedor "tem um nível muito saudável de teimosia". Outros tópicos ficam para os negócios trabalharem internamente após a aceleração, mas, "se o empreendedor não vir valor, não adianta".

A comunicação pode surgir como tópico da aceleração na etapa de diagnóstico, em que se verifica a importância da pauta para o negócio. Luciana Branco contou que, desde que começou a atuar no Quintessa como mentora, fez somente uma mentoria em longo prazo ${ }^{35}$ e, mais comum, alguns "trabalhos pontuais em comunicação", podendo abranger desde telefonemas de 30 minutos a reuniões de duas horas. "Por eu estar no CIVI-CO, vira e mexe eles me chamam: 'Lu, vamos tomar um café com um empreendedor?' e daí a gente faz uma mentoria pontual', o que demonstra certa aleatoriedade com que a questão da comunicação é tratada dentro dos programas de aceleração do Quintessa.

Maércio Diogo disse que, independentemente da fase do negócio, o empreendedor dificilmente apresenta uma demanda ligada à comunicação. Não é o que observamos nos negócios consultados: em estágio de ganhar escala, E-Moving e 4YOU2 apontam a necessidade e intenção de investir mais em comunicação. Na Banca do Bem, em estágio de validação, a preocupação com comunicação também existe, tanto no posicionamento do negócio no mercado quanto ligada ao estímulo ao consumo consciente entre seus clientes.

\footnotetext{
${ }^{35}$ Para o projeto Vir a ser, sobre logística reversa, do grupo Gaia Social. A mentoria consistiu em encontros quinzenais com os empreendedores por um período de quatro meses.
} 
Rodrigo Pipponzi conta que assuntos ligados à comunicação foram pouco abordados durante a aceleração, "mas hoje é um assunto super em pauta" na Banca do Bem. O empreendedor explica que a comunicação foi mencionada na aceleração como um "instrumento", mas não foi tratada como prioridade do processo, que focou o modelo de negócios. A aceleração durou entre cinco e seis meses.

Observamos na 4YOU2, na E-Moving e na Banca do Bem que a comunicação foi tema pouco abordado durante a aceleração do Quintessa, mas é hoje assunto relevante de todos os negócios consultados. Isso levanta a questão: a quase ausência da comunicação nos programas de aceleração seria um posicionamento do Quintessa ou, como alega a aceleradora, dos negócios acelerados?

Em nossa análise, e numa perspectiva de comunicação integrada, a comunicação é central nos eixos principais dos programas de aceleração do Quintessa: na estratégia, uma vez que a construção do plano de negócios, por si só, é um processo comunicativo e participativo, e o seu posicionamento no mercado se liga diretamente à comunicação institucional; na gestão, vinculando-se, sobretudo, à comunicação administrativa, tendo em vista a formalização de fluxos e processos produtivos; nas vendas, vinculada à comunicação mercadológica e, cada vez mais, à comunicação institucional; e no time, que mantém relação direta com a comunicação interna e a articulação das equipes de trabalho.

Assim, a construção do plano de negócios, sob a ótica de vendas, tal qual propõe o Quintessa, responde a uma necessidade latente do empreendimento social acelerado, porém se afasta do modelo de comunicação integrada logo no estágio inicial do negócio, pelo qual se preconiza a demanda de uma estratégia global de comunicação, em suas diferentes dimensões.

\subsubsection{A avaliação dos empreendedores}

Na opinião de Gustavo Fuga, a 4YOU2 teve uma aceleração "atípica”. Foram dois anos com o Quintessa, numa época em que a aceleração era gratuita. "Novos desafios iam aparecendo e a gente foi ficando", disse Fuga. A 4YOU2 foi um dos primeiros negócios a participar dos programas de aceleração do Quintessa, e a avaliação do empreendedor é bastante positiva: "life changing", resume Fuga. 
"Eu falo pros empreendedores que vêm pedir minha opinião sobre o Quintessa: não existe varinha mágica", diz Gabriel Arcon, ressaltando que cabe ao empreendedor tirar o máximo possível da aceleração. "É mais um braço trabalhando com você", sobre a ajuda do gestor no dia a dia do negócio. Para o empreendedor, a E-Moving teve no Quintessa uma "base de apoio e confiança pra poder crescer" e destaca, entre os pontos positivos da aceleração, a mentoria: o mentor "foi muito bem escolhido" e deu mais segurança para o desenvolvimento do negócio. "Até hoje eu sou amigo do mentor", diz Gabriel Arcon.

Bem avaliado pelos negócios acelerados, o mentor figura como um público estratégico do Quintessa, sendo necessário, porém, um mapeamento mais completo a fim de compreender melhor as expectativas desse público, com o objetivo de ampliar a participação dos mentores em ações da aceleradora. Luciana Branco contou que sua motivação para ser mentora foi, “depois de uma trajetória profissional, saber que você tem como colaborar com o seu próprio conhecimento para negócios que têm um pensamento contemporâneo de atuação". A profissional ressalta, entre os aspectos positivos da mentoria, em primeiro lugar, a troca de conhecimentos com os empreendedores e, em segundo lugar, com mais tempo, a possibilidade de estabelecer parcerias comerciais com os negócios acelerados.

Rodrigo Pipponzi conta que a aceleração consolidou uma nova estratégia para a Banca do Bem, que se tornou uma spin-off da Editora MOL. Apesar de o plano de negócios desenvolvido na aceleração "mudar o tempo todo", o conceito geral está presente, acredita o empreendedor, que avalia que os "insights" de todo o processo de aceleração foram importantes. Ele afirma ainda que faria novamente a aceleração, daqui a um ano, em outro estágio do negócio, e que já recomendou a aceleração para outros empreendedores.

Os programas de aceleração do Quintessa são bem-avaliados pelos três empreendedores entrevistados, ressaltando-se aspectos diferentes em cada negócio, o que reforça o nível de personalização defendido pela aceleradora: no caso da E-Moving, a mentoria; na Banca do Bem, o apoio na construção do plano de negócios; e na 4YOU2, o auxílio para estruturar a gestão do empreendimento.

O negócio social acelerado pelo Quintessa é ainda acompanhado a posteriori: no mínimo, realiza-se uma reunião anual para avaliar resultados e perspectivas futuras. Todos os negócios acelerados passam a fazer parte da "Rede Quintessa", conta Maércio Diogo. Há encontros regulares entre os negócios, parcerias entre os empreendedores, consulta à rede 
quando um especialista em determinado tema é necessário e recomendação de serviços. No caso de Gustavo Fuga e Rodrigo Pipponzi, também é comum a participação em eventos do setor.

Após a aceleração, é natural que alguns negócios sejam mais próximos do Quintessa do que outros. Porém, se o impacto social da aceleradora é avaliado pelo impacto social alcançado pelos negócios acelerados, é preciso um olhar mais atento a este público. Ao invés de uma comunicação pontual e fragmentada, o Quintessa pode se valer de uma classificação de públicos (FRANÇA, 2010) que avalie objetivos, expectativas de relacionamento, nível de dependência e expectativas dos públicos para traçar uma comunicação institucional estratégica com os negócios acelerados, que pode reverter em parcerias e reputação positiva para aceleradora.

\subsubsection{Categoria 3: A filosofia da comunicação integrada em negócios sociais}

"A cabeça funciona em fragmentos", revela Thaís Fontoura sobre a dificuldade de construir um planejamento de comunicação para a aceleradora. "Meu sonho é fazer um plano de comunicação para o Quintessa", afirma, ao avaliar que a comunicação da aceleradora é essencialmente operacional ("Somos executores de comunicação") e que as ações são trabalhadas no cotidiano, sem planejamento prévio. Na opinião da entrevistada, a falta de uma comunicação mais bem estruturada tem seus efeitos sentidos, por exemplo, na busca de novos clientes para os programas de aceleração. O desafio atual do Quintessa é atrair "leads qualificados", obtidos hoje principalmente por busca ativa, contou Thaís. Porém, a busca ativa toma muito tempo do Quintessa, não sendo o modelo ideal de prospecção de novos clientes. "Ainda não entendemos como fazer isso e como se liga a comunicação", avalia a profissional. Observa-se, aqui, a necessidade de uma pesquisa mais aprofundada para um planejamento de comunicação mais eficiente e eficaz com os empreendedores (KUNSCH, 2016), iniciativa que estava nos planos do Quintessa à época da entrevista, mas que foi descontinuada por opção da aceleradora.

Para Maércio Diogo, a 4YOU2 é um exemplo de negócio social que faz uma boa comunicação: "Explica, entende e você quer contratar". O gestor de projetos esclarece que, entre os negócios acelerados pelo Quintessa, o conhecimento sobre a área de comunicação é 
em geral baixo e centrado, sobretudo, em práticas de vendas e marketing. Há "pouco branding", sendo necessário reorganizar a comunicação a partir da perspectiva do cliente. A mentora Luciana Branco afirma que há um problema anterior, que é a clareza na definição do que é negócio social e qual problema ele quer ajudar a resolver. A jornalista indica que, antes de comunicar aos públicos, o empreendedor precisa fazer o que ela chama de "lição de casa":

Eu acabo sempre provocando os mentorandos que estão querendo se comunicar a realmente definir que negócio eles têm. Na hora que você sai de casa para falar, você tem que estar com a sua lição de casa - do business - muito bem-feita. Senão, você quer que a comunicação solucione um problema que é de gestão.

Contudo, há dificuldade em conceber um discurso organizacional apropriado aos negócios sociais, avalia Maércio Diogo: “Os negócios são muita coisa e fazem muita coisa”, sendo difícil às vezes entender o que a empresa de fato é, avalia o gestor. Perspectiva semelhante tem a mentora Luciana Branco: "Especialmente nos negócios de impacto social, uma das principais dificuldades é dar muitos passos para trás e escolher um discurso mais didático a fim de falar com mais gente", caso contrário, os empreendedores irão falar muito bem com "a bolha de impacto social", mas, por outro lado, não alcançarão o impacto desejado, avalia a jornalista. "Na cabeça da empresa, isso não é comunicação, é discurso de vendas", explica o gestor Maércio Diogo.

\subsubsection{Políticas, filosofias e objetivos da comunicação}

A comunicação, como em qualquer outro negócio, pode contribuir em vários aspectos, acredita Gustavo Fuga: branding, atração de clientes, atração de talentos, manutenção de uma boa rotina de trabalho e posicionamento do negócio para o mercado como um todo são alguns exemplos citados pelo fundador da 4 YOU2. "A diferença é que você tem ali a sua causa, tem o seu ecossistema", complementa o empreendedor.

A mentora Luciana Branco diz apontar, entre os negócios em processo de aceleração, a importância, na comunicação, de pensar nas estratégias, ter clareza dos objetivos do negócio e dos públicos que quer atingir para, assim, desenvolver estratégias discursivas adequadas para estes públicos. "Sair uma matéria no jornal não significa que o 
negócio está indo bem", diz, ao reforçar a importância do planejamento da comunicação em um negócio social.

Os negócios acelerados, apesar de mais jovens, parecem mais amadurecidos quanto às suas políticas e estratégias de comunicação do que o próprio Quintessa. Nos negócios já estruturados (4YOU2 e E-Moving), a comunicação é ligada a uma área de marketing, em conexão direta com o presidente da empresa. "Comunicação pra gente é tudo. É como a gente consegue mostrar para as empresas que vale a pena oferecer uma forma alternativa de mobilidade urbana", contou Gabriel Arcon sobre a E-Moving. Sobre o planejamento de comunicação, ele explica que "estamos planejamento mais", com um mês e meio a dois meses de antecedência - pouco tempo, se comparado a outras áreas do negócio. A E-Moving costuma planejar suas ações de comunicação articuladas com o que está acontecendo na cidade de São Paulo, com o objetivo de "juntar a nossa estratégia com o macroambiente", explica o empreendedor.

Gabriel Arcon explica ainda que as frentes de comunicação da E-Moving são muito paralelas e "quanto mais de cada uma, melhor". Ele possui hoje gerentes em cinco frentes: operações, financeiro, vendas, tecnologia e marketing, sendo que este último engloba também a área de comunicação. São quatro profissionais na equipe de marketing, trabalhando em comunicação on-line e institucional, trade offline, design e atendimento ao cliente, além de uma assessora de imprensa externa. Os gerentes se reúnem semanalmente para discutir o andamento do negócio e Arcon compreende que a comunicação da E-Moving está hoje alinhada com a estratégia do negócio: "No final do dia, o objetivo é alugar mais bicicletas".

Rodrigo Pipponzi acredita que "o grande ativo que a gente precisa ter é comunicação aqui dentro". Para isso, a Banca do Bem está desenvolvendo um projeto de comunicação, posicionamento e linguagem da marca, "tudo conectado com a aceleração" e com o envolvimento da "marca-irmã", Editora MOL.

Na 4YOU2, Gustavo Fuga revela que a comunicação já foi planejada, "parou” e, agora, terá o planejamento retomado, com a recente contratação de uma gerente de marketing mais experiente. Os investimentos em comunicação hoje são divididos, segundo o empreendedor, da seguinte forma: $70 \%$ em comunicação mercadológica (para atrair novos alunos), 20\% para comunicação institucional e 10\% para comunicação mercadológica com empresas (B2B). A 4YOU2 conta com uma área de marketing ligada diretamente ao 
presidente e fundador e dividida em três frentes de atuação - institucional, comunicação B2B e B2C. Hoje, são três funcionários atuando na área, que, segundo Gustavo Fuga conta, é uma das que terão mais investimentos na 4YOU2 em 2019.

Quanto aos investimentos em comunicação, os autores consultados não expressam valores propriamente ditos, mas sim a necessidade de uma comunicação estratégica, permanente e planejada. Ou seja, ainda que não sejam investidas grandes somas na comunicação do negócio social, sobretudo nos estágios iniciais, este investimento (de tempo, recursos materiais e humanos) precisa ser regular, planejado e em consonância com os objetivos sociais e financeiros do negócio. A mentora Luciana Branco reforça esse posicionamento ao afirmar que os empreendedores devem ter clareza dos públicos com os quais quer dialogar e "fazer poucas ações constantes para que o seu público realmente entenda o que você quer falar".

Quanto ao planejamento de comunicação, adotamos a classificação de Kunsch (2006) para as realidades comunicacionais no Quintessa e nos negócios consultados. Em nossa análise, 4YOU2, E-Moving e Banca do Bem são organizações em que a comunicação tem valor tático e técnico, com fins mercadológicos, mas ainda sem uma estratégia global de comunicação. Quanto ao Quintessa, com base nos dados coletados em entrevista e pesquisa documental, a aceleradora se vale de uma comunicação ainda reativa e improvisada, sem planejamento adequado de instrumentos e técnicas comunicacionais.

Ao chegar no programa de aceleração, Maércio Diogo explica que muitos negócios gostariam de investir mais em comunicação, mas reclamam de falta de tempo ou dinheiro para fazer isso. "O problema de caixa fala mais alto", avalia o gestor de projetos. Opinião semelhante tem a mentora Luciana Branco, que ressalta a falta de verbas nas startups para investimentos dessa natureza, além da própria falta de tempo para se dedicar à comunicação do negócio: "É muito desafiador você fazer tudo. São escolhas de dedicação de tempo que precisam ser feitas. E alguns naturalmente escolhem, e eu acho que tá certo, fechar um negócio a comunicar". Sobre a própria comunicação do Quintessa, Thaís Fontoura diz ter a sensação de que "falta equipe para fazer a comunicação da forma certa". Terceirizar ou ter uma equipe própria de comunicação é uma das atuais dúvidas da aceleradora. Outro aspecto ressaltado por Maércio Diogo é o fato de que a maioria das agências de comunicação oferece 
produtos e serviços considerados caros pelos negócios sociais. Ele sugere que as agências tenham modelos "mais acessíveis, mais rápidos e mais aderentes aos negócios sociais".

Em nossa análise, empreendimentos sociais têm nas práticas das grandes empresas uma referência em assuntos relacionados à comunicação organizacional. É recorrente, no mercado, a contratação de agências de comunicação para o desenvolvimento de campanhas e outros produtos comunicacionais. Como não possuem recursos para contratar este tipo de serviço, e na ausência de outros modelos bem-sucedidos no ecossistema de negócios sociais, os empreendedores sociais sentem-se desestimulados a investir em comunicação. Do lado das agências de comunicação, os profissionais da área poderão se valer da oportunidade de atender a um público negligenciado pelo mercado e propor ao empreendedor soluções inovadoras e multidimensionais que deem visibilidade aos produtos e, ao mesmo tempo, à causa social do negócio.

Na E-Moving hoje são gastos cerca de R \$ 20 mil por mês em marketing, valor que varia conforme o faturamento do negócio. Para Gabriel Arcon, o desafio da E-Moving e de outras startups é justamente saber "comofazer mais com menos". Luciana Branco toma outro caminho: "Como ser relevante para o seu interlocutor? Eu acho que essa é a grande pergunta da comunicação hoje". Para Thaís Fontoura, "o dilema do empreendedor é o dilema do Quintessa. Não tem braço, não tem dinheiro, então acaba não fazendo da forma certa". Thaís entende que, no caso do Quintessa, é preciso "partir do zero", "parar de empurrar com a barriga" e começar a fazer. A visão da publicitária vai ao encontro da posição de Luciana Branco quanto aos negócios acelerados: "Minha maior colaboração a eles tem sido num chamado para o negócio se estruturar de verdade", a fim de fazer uma "comunicação que fale com a vida real".

Quanto aos públicos dos negócios, as respostas são, no geral, centradas no "cliente": a 4YOU2 aponta como principais públicos os alunos (atuais e potenciais), a equipe e seus professores de inglês. A Editora MOL tem como públicos estratégicos os grandes varejos, que podem gerar grandes volumes de vendas; já na Banca do Bem, os clientes em potencial são o "consumidor consciente" e as empresas ligadas às causas socioambientais. O cliente potencial da E-Moving é o executivo que não quer perder tempo no trânsito, traçando um perímetro que passa por trechos da Zona Sul, Oeste e Centro da cidade de São Paulo. 
Nos negócios consultados, observamos o predomínio da classificação tradicional em público interno (funcionários) e externo (clientes), salvo raras referências ao ecossistema de negócios sociais. Outros modelos de classificação de públicos, que ressaltam a influência e relação direta com a organização, tal qual sugerem França e Ferrari (2008), podem contribuir para um planejamento mais estratégico da comunicação. Nesse sentido, são referências o mapeamento de públicos de França (2012), que avalia dependência, participação e grau de interferência em relação à organização, e Grunig e Hunt (1984), que estabelecem uma teoria situacional para o relacionamento entre públicos e organização.

Quanto aos instrumentos de comunicação, Kunsch (2016) ressalta que a escolha entre os vários instrumentos e técnicas deverá ser respaldada por um planejamento estratégico. Nos negócios sociais analisados, porém, observamos que os instrumentos de comunicação adotados objetivam, salvo ações com público interno, o relacionamento com o cliente e o aumento das vendas. Observamos, ainda, a necessidade de um esforço coordenado dos negócios com os diferentes instrumentos e técnicas de comunicação, em termos de integração e complementaridade entre si (CASALI, 2002). Segundo o gestor Maércio Diogo, entre os negócios acelerados pelo Quintessa os principais instrumentos utilizados são mídias sociais, site e apresentações (de vendas e institucionais).

A 4YOU2 adota como principais instrumentos de comunicação as mídias on-line (redes sociais e site), parcerias locais e panfletagem em estações de trem e metrô em locais considerados estratégicos para a divulgação das escolas da rede. Para o público interno, há uma newsletter e reuniões regulares. Ainda em fase de estruturação, a comunicação da Banca do Bem se dá, sobretudo, pelo site, redes sociais (Facebook e Instagram) e central de assinaturas. A comunicação da E-Moving desenvolve-se em meio digital, com ações em eventos do setor, blitz nas ruas e participação em eventos com a parceira Movida, empresa de locação de carros que está buscando um novo posicionamento no mercado, explica Arcon. Para a comunicação com o cliente final, a E-Moving quer ir na contramão do mercado e estar nas ruas, pois acredita ter em mãos um produto que chama a atenção. "Qualquer coisinha que a gente faz de diferente sai na capa do UOL", diz Gabriel Arcon sobre a boa receptividade do negócio na imprensa. 


\subsubsection{Dimensões da comunicação integrada}

Quanto à comunicação mercadológica da E-Moving, "estamos descobrindo como encantar mais o nosso cliente", conta Gabriel Arcon; "nosso principal desafio é o awareness. É as pessoas saberem que a gente existe". Ele explica que quem conhece a E-Moving "se encanta pelo negócio", pois ele traz um impacto muito rápido na vida das pessoas. Como fazer isso bem e com pouco dinheiro é, contudo, uma dificuldade do negócio.

No Quintessa, toda a comunicação da aceleradora tem um viés de prospecção, explica Thaís Fontoura. Por exemplo, ao organizar um evento sobre investimentos em negócios de impacto social, a intenção é divulgar o programa de assessoria na captação de fundos.

Além do cliente final, as grandes empresas têm se tornado um público estratégico na comunicação mercadológica dos negócios sociais acelerados e do próprio Quintessa. Para Maércio Diogo, a receptividade das grandes empresas também está crescendo: “Quando você já não precisa explicar mais o que é, já é um indicativo" dessa mudança de percepção quanto aos negócios sociais. O gestor acredita que o investimento em negócios sociais é uma maneira de as empresas inovarem de forma mais positiva. Outra possível causa para essa mudança é o olhar das grandes empresas para estratégias de marketing de causas, em parceria com negócios sociais (COMINI; FISCHER, [2017]).

Todos os negócios consultados têm produtos e serviços para empresas. Gabriel Arcon, da E-Moving, conta que investe $35 \%$ de recursos na comunicação B2B, que hoje conta com uma equipe exclusiva de quatro pessoas, e 65\% na comunicação B2C. Para o empreendedor, a comunicação do negócio implica um "aculturamento", seja de pessoas, seja de empresas, a fim de modificar conceitos e hábitos quanto à mobilidade urbana. Nesse aspecto, Luciana Branco alerta para a necessidade de pensar em uma comunicação "menos julgadora e mais convidativa" para promover mudanças de comportamento na sociedade.

Tal perspectiva dialoga com a percepção de Moya (2016) e Kunsch (2009), que destacam a importância da comunicação em todas as suas dimensões para a conscientização e promoção de mudanças em direção a um estilo de vida mais sustentável. A sociedade, contudo, está longe de compreender amplamente o que são os ODS, o que dificulta a 
comunicação dos negócios sociais, que esbarram na falta de objetividade e didatismo para falar com seus públicos, na opinião da mentora Luciana Branco:

Eu acho fundamental que a gente seja muito objetivo, porque com os negócios de impacto a conversa é muito etérea, sabe, muito idealizada. Acaba não sendo uma comunicação eficiente no sentido de transformar o comportamento humano. E a comunicação tem esse papel nos negócios de impacto.

A comunicação do Quintessa com grandes empresas requer outra abordagem, avalia Thaís Fontoura. "É uma outra forma de chegar nessas pessoas", e a aceleradora ainda está descobrindo qual tipo de linguagem deve usar para se conectar com o mercado. A entrevistada conta ainda que o Quintessa está buscando o seu "tom de voz" para falar com o empreendedor e para falar com as grandes empresas. A profissional entende que é preciso parar de usar termos sobre os quais já existam ideias pré-concebidas e que podem afastar potenciais clientes e parceiros.

A dificuldade de comunicação com grandes empresas, relatada pela profissional, é somente uma questão de linguagem ou da ausência de um plano de comunicação dirigido aos públicos do Quintessa? Em nossa análise, antes da terminologia, há um problema de estratégia de comunicação com os públicos da aceleradora, principalmente o empreendedor (que é público estratégico das ações de comunicação do Quintessa hoje) e da grande empresa (público potencial, com o qual a aceleradora quer desenvolver programas de parceria). Com uma cartela de produtos específicos para o B2B, os negócios acelerados em análise parecem ter mais clara a comunicação que querem fazer com as grandes empresas do que o próprio Quintessa. Sem produtos ou serviços específicos para oferecer àquele público, de que maneira a aceleradora propõe gerar valor para tais organizações, sem perder com isso seu foco no impacto social?

Já é claro para o Quintessa que a prospecção de negócios para os programas de aceleração é diferente do diálogo com as grandes empresas. Entende também que os ODS são importantes para a comunicação com este público estratégico, ainda que não seja claro como fazê-lo. Em nossa análise, a solução passa por um planejamento global de comunicação (KUNSCH, 2016), em que seja reforçada a missão, a função do negócio e a sua contribuição para a sociedade (FELIZOLA et al., 2009), bem como as estratégias de relacionamento com seus públicos, dando destaque a aspectos ainda pouco trabalhados na comunicação institucional da aceleradora: portfólio e os cases dos negócios acelerados, visibilidade dos 
resultados alcançados em função dos ODS e compartilhamento de conhecimentos adquiridos em dez anos de atuação com negócios sociais.

Hoje, como explica a entrevistada Thaís Fontoura, o Quintessa quer "sair da bolha" para falar com empreendedores de outros segmentos de mercado além do ecossistema de negócios sociais, em que a presença da aceleradora está relativamente consolidada. Para isso, ampliar a noção de públicos pode contribuir para expandir a atuação da aceleradora e gerar novos negócios e mais impacto social. A prospecção da E-Moving é exemplo da proposta da aceleradora de buscar empreendedores e explorar outros nichos de mercado fora do ecossistema de negócios sociais.

Observamos que esse ecossistema, recorrente na literatura consultada (COMINI, 2016; KIYAMA; COMINI; D’AMARIO, 2014; REFICCO; VERNIS, 2010), é pouco mencionado pelos empreendedores - que se limitam a participar de eventos e atuar como porta-vozes do setor na mídia, mas com pouco a acrescentar em termos de parcerias com outros negócios sociais e atores do ecossistema. Todos os empreendedores consultados afirmam buscar parcerias com grandes empresas a fim de aumentar a lucratividade e gerar mais impacto social. Tal cenário remete à análise de Oliveira Filho, Kiyama e Comini (2013) de que o ecossistema de negócios sociais é, na verdade, tratado como um todo que, na prática, não existe. Os negócios sociais consultados parecem ainda estar restritos às iniciativas B2B e B2C, estando longe da ideia de constituir alianças intersetoriais (FISCHER, 2012) mais amplas para a resolução de problemas sociais. Ou seja, no final do dia, cada empreendedor social retorna ao seu segmento de mercado.

Sobre a comunicação institucional, "a não ser que seja muito sensível ao empreendedor, a gente não consegue [incluí-la nos programas de aceleração]”, explica Maércio Diogo. "Eu vejo valor, mas na cabeça dos negócios”, pela falta de tempo e dinheiro, a comunicação é entendida como uma etapa posterior. "Quando ele consegue colocar para vender, daí a comunicação entra como refinamento do negócio", disse o gestor. Apesar disso, Maércio Diogo entende que:

A comunicação da empresa em si é tão importante quanto o produto que ela vende. A maioria dos negócios tem dificuldade de contar a sua história. Quando ele consegue amarrar a narrativa [do negócio] a vender mais, daí o empreendedor compra a ideia. 
A comunicação institucional é uma dimensão recente no Quintessa, conta Thaís Fontoura: "A gente tem dez anos de história. A gente tem uma certa bagagem para dividir com quem tá entrando nesse setor. Vamos assumir essa responsabilidade”. Na Editora MOL, "a gente se comunica totalmente como negócio de impacto social", ressalta Rodrigo Pipponzi. "Há um entendimento muito claro de o impacto social ser o nosso core e não uma coisa a mais. Não é nem um diferencial, é o que a gente ê”, explica o empreendedor.

Gustavo Fuga conta que a 4YOU2, por ser um negócio social, ganha reconhecimento em espaços que não são necessariamente ligados ao segmento em que atua. A comunicação institucional da 4YOU2 mantém forte vínculo com a tese de mudança do negócio, com a causa e o impacto social. Fuga explica ainda que, na 4YOU2, eles têm a visão de que fazem parte do ecossistema de negócios sociais e que têm a responsabilidade de fomentar esse setor: "Nossa comunicação é um pouco ativista nesse sentido". Na comunicação mercadológica, contudo, o fato de a 4YOU2 ser um negócio social não tem o mesmo valor. "O aluno não se atrai por isso, ele quer o serviço", explica Fuga. O empreendedor aponta dois pontos positivos principais na comunicação institucional do negócio: atração de talentos e parcerias.

Na perspectiva de Kunsch (2016) para as dimensões da comunicação, observamos o forte vínculo entre a comunicação institucional e a mercadológica na E-Moving e na Banca do Bem. Quanto à comunicação institucional, a 4YOU2 se difere das demais: o negócio revela a presença de múltiplas identidades organizacionais (SMITH; GONIN; BESHAROV, 2013); contudo, as tensões e divergências observadas por Smith, Gonin e Besharov (2013) parecem menos presentes nos negócios consultados e devem ser objeto de investigação mais aprofundada em estudos futuros.

No Quintessa, observamos que a comunicação institucional é a dimensão mais fragilizada da comunicação da aceleradora, percebida, principalmente, ao buscar parcerias no mercado, cujo nível de profissionalização é maior do que o dos empreendedores sociais que estão acostumados a prospectar. Cabe observar ainda que todos os negócios entrevistados reforçam a importância da comunicação institucional para a comunicação B2B, em que se ressaltam a missão e o impacto social.

Thaís Fontoura entende que um negócio social é como outro qualquer e, portanto, deve seguir as mesmas diretrizes de um negócio tradicional, ressaltando, em sua 
comunicação, que a sua razão de existir é a resolução de um problema socioambiental. Para Maércio Diogo, contudo, há uma cobrança maior em ser um negócio social: a pergunta “estou ou não resolvendo um problema?" é recorrente entre os empreendedores, diz o economista. Para a mentora Luciana Branco, em um contexto no qual "toda a comunicação precisa ser muito responsável", os negócios sociais nascem com um "telhado de vidro" que um negócio tradicional inicialmente não tem. Gabriel Arcon, da E-Moving, ressalta que a comunicação com o cliente é de fato diferente: "Eu não tô vendendo um produto, eu tô vendendo algo que faz bem para todo mundo, que terá impacto na vida dele e para a sociedade em geral’.

Sobre a comunicação interna, os entrevistados ressaltam a formação de uma boa equipe para o sucesso do negócio. Para os programas de aceleração do Quintessa, “o modelo [de negócios] não precisa estar pronto, mas o time precisa ser bom para colocar um futuro modelo em prática. [...] Quem eu atraio vai fazer diferença para o negócio dar certo", diz Maércio Diogo. Para Gustavo Fuga, a comunicação do propósito do negócio social contribui diretamente para atrair talentos.

Perspectiva semelhante é encontrada na E-Moving. Para Gabriel Arcon, ser um negócio de propósito retém talentos que estariam ganhando mais dinheiro em outras empresas, "mas escolheram estar aqui por causa do impacto positivo na sociedade". Hoje, entre 60 e $70 \%$ dos funcionários administrativos da E-Moving se deslocam para o trabalho de bicicleta. Além disso, ser um negócio em estágio de escala atrai para a equipe profissionais com perfil empreendedor, e "a gente incentiva isso aqui". A E-Moving adota outras práticas sustentáveis no negócio - por exemplo, não utiliza copos plásticos no escritório, oferece doação de pratos de comida por quantidade de bikes alugadas e doa bicicletas que não são mais utilizadas para o QG das Capivaras, uma bicicletaria filantrópica do interior de São Paulo. Tais ações somadas, na visão do empreendedor, modificam o perfil das pessoas que trabalham na E-Moving.

A comunicação institucional alinhada com o propósito do negócio contribui, na perspectiva dos empreendedores, para atrair um público interno engajado na causa social. Se a comunicação institucional atrai talentos, a função da comunicação interna é retê-los e aproveitá-los melhor para a missão social do negócio. Os empreendimentos acelerados não apresentaram nenhum tipo de estrutura interna diferenciada para as lógicas sociais e econômicas do negócio, como sugerem Smith, Gonin e Besharov (2013); ao contrário, 
mantêm estrutura semelhante à dos negócios tradicionais. Nenhum dos negócios acelerados foi identificado como inclusivo, mostrando ser esse um desafio ainda maior a ser enfrentado pelos negócios sociais.

As respostas quanto à avaliação da comunicação foram, em geral, lacônicas. No Quintessa, Thaís Fontoura explica que os indicadores de resultados são relacionados à prospecção de novos negócios - por exemplo, depois de um evento, quantos negócios se converteram em lead qualificado ou entraram nos programas de aceleração? Quanto à comunicação institucional, é feito um controle, mas não uma avaliação de resultados. Gustavo Fuga explica que eles estão desenvolvendo métricas para avaliar a comunicação, não sendo ainda possível fazer um balanço dos resultados. "O desafio de toda a empresa que faz comunicação é achar o canal certo, investir e conseguir mensurar os resultados", avalia Gabriel Arcon.

Os negócios sociais requerem um outro olhar sobre a comunicação, que não muda essencialmente em termos de técnicas e instrumentos, mas de trocas interativas, conteúdo da mensagem e proposta de valor. A contribuição da comunicação para a solução de problemas sociais passa necessariamente por criar espaços de diálogo e participação inclusivos, acesso à informação e tomada de consciência, mudança de comportamento e engajamento com uma causa.

\subsection{Limitações e futuros estudos}

Cientes das limitações deste estudo e da existência de outros modelos organizacionais no ecossistema de negócios sociais, entendemos que sejam necessárias pesquisas mais aprofundadas a fim de compreender quais fatores são determinantes para uma comunicação integrada de impacto social. É necessário continuar se debruçando sobre as questões abordadas nesta dissertação, inclusive com outras metodologias de pesquisa. Para tanto, propomos uma matriz de estudos, ainda em construção, para a comunicação integrada em negócios sociais.

A proposta de estudo do processo da comunicação em negócios sociais está sendo desenvolvida com base na estrutura apresentada no Quadro 1 desta dissertação, adaptada de Comini (2016), e tendo como referência os estudos de comunicação integrada de Kunsch 
(1997, 2006, 2007a, 2016). Pretende-se com isso estabelecer fatores para classificar a comunicação integrada em negócios sociais de acordo com as suas práticas organizacionais - vinculadas a uma lógica de mercado ou a uma lógica social (Quadro 10).

Quadro 10 - Proposta para a classificação de fatores da comunicação integrada em negócios sociais

\begin{tabular}{|l|l|l|l|}
\hline $\begin{array}{l}\text { Dimensões da } \\
\text { comunicação integrada }\end{array}$ & Fatores & Lógica de mercado & Lógica social \\
\hline Comunicação administrativa & & & \\
\hline Comunicação interna & & & \\
\hline Comunicação institucional & & & \\
\hline Comunicação mercadológica & & & \\
\hline
\end{tabular}

Fonte: Em elaboração pela autora e adaptado de Comini (2016).

Tal qual a proposta de Comini (2016), cada fator comunicacional receberia pontuação entre 10 (lógica social) e -10 (lógica de mercado). São fatores em estudo pela investigadora para avaliar uma comunicação de impacto social nas organizações híbridas: os fluxos organizacionais produtivos e estruturas de trabalho, na dimensão da comunicação administrativa; as relações interpessoais e a participação em processos decisórios, na dimensão da comunicação interna; a intencionalidade e transparência do discurso organizacional, na dimensão da comunicação institucional; e, na dimensão mercadológica, o relacionamento com o cliente que, numa lógica social, deve enfatizar processos comunicativos de tomada de consciência e aprendizagem.

Nosso objetivo é desenvolver uma matriz de estudos do processo de comunicação em negócios sociais (Figura 12) passível de ser aplicada em diferentes organizações de natureza híbrida. Assim, depois de classificar os fatores de comunicação em suas dimensões administrativa, interna, institucional e mercadológica, os resultados alcançados seriam aplicados em uma matriz de estudos da comunicação em negócios sociais formada por um único eixo, um continuum, que em um extremo apresenta os negócios sociais cuja comunicação mantém forte influência das práticas de mercado, similar a uma empresa tradicional, e, no outro, organizações que atuam, em sua comunicação, sob uma lógica social. 
A seguir, observamos um exemplo em que a comunicação institucional e a mercadológica são quase dicotômicas: por um lado, uma comunicação institucional com forte ênfase social; do outro, uma comunicação mercadológica com influência de uma lógica de mercado (Figura 12).

Figura 12 - Matriz em construção para estudos da comunicação integrada em negócios sociais

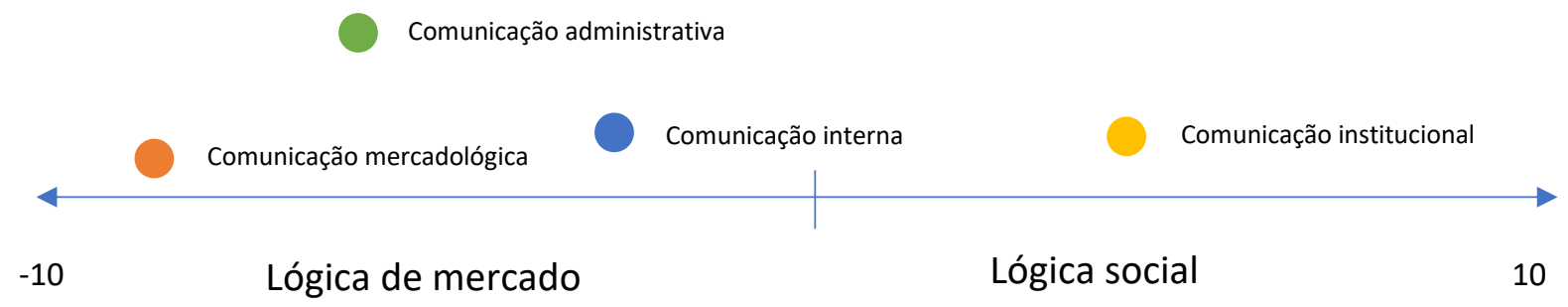

Fonte: Em elaboração pela autora e adaptado de Comini (2016).

Nossa proposta é avaliar, em estudos futuros, as práticas comunicacionais dos negócios sociais sob as dimensões da comunicação integrada. À luz dessa filosofia, a compreensão do processo comunicacionais em negócios sociais pode ser ampliada a fim de contemplar intencionalidades múltiplas, gerar novos sentidos e produzir efeitos diversos em seus públicos - mediação, inclusão, conscientização sobre causas, formação de alianças, mudanças comportamentais, mobilização - e, em última instância, causar impacto social. 


\section{CONSIDERAÇÕES FINAIS}

As questões de pesquisa estabelecidas nesta dissertação ajudaram a guiar a investigação e, nestas considerações finais, nossa intenção é retomá-las a fim de discutir as respostas obtidas por meio do referencial teórico e da pesquisa documental. Ressaltamos nossa opção por um estudo com recorte claro e bem definido - uma investigação qualitativa e exploratória - e que as conclusões aqui apresentadas, apesar de não poderem ser generalizadas para todo o ecossistema de negócios sociais, indicam tendências importantes e que podem contribuir tanto para a comunicação de outros negócios sociais e aceleradoras quanto para o campo da comunicação organizacional. Em nossa escolha de estratégias metodológicas, ressaltamos ainda a perspectiva de Yin (2001, p. 161), para quem “os estudos de caso possuem um público em potencial muito maior do que outros tipos de pesquisa”.

Assim, as questões iniciais propostas pelo nosso estudo são aqui compreendidas em função dos nossos objetivos específicos, conforme descrito a seguir, e considerando os papéis múltiplos que a comunicação pode exercer nas organizações.

Nas categorias iniciais de análise da pesquisa empírica e no primeiro capítulo da dissertação, propomos refletir sobre os negócios sociais em um contexto de desenvolvimento sustentável. O posicionamento de um negócio social no ambiente em que está inserido é compreendido como um processo comunicativo que passa pela definição de estratégias e objetivos. É apontado pela pesquisa empírica o fato de os negócios sociais identificarem como problemas de comunicação com os públicos questões que, na verdade, estão ligadas a processos de gestão e, consequentemente, a processos comunicacionais administrativos e internos. Muitos negócios comunicam para os públicos antes de comunicar para si mesmos, ou seja, antes de definir internamente o que são e de que forma querem contribuir para o desenvolvimento social e sustentável.

A opção do Quintessa e dos negócios acelerados pela substituição do termo "negócio social" por "negócio de impacto" é reveladora em diversos sentidos: pela tentativa de aproximação com o mercado e, portanto, com práticas corporativas tradicionais; pelo peso e maior responsabilidade que carregam os negócios sociais ao optar pelo empreendedorismo para contribuir para a resolução de um problema coletivo de alta complexidade; pela intenção de afastar-se de modelos organizacionais associados à filantropia e sem fins lucrativos. É 
preciso refinar o aspecto social dos negócios, que podem ter modelos de organização e gestão muito diferentes entre si, e entendemos que a comunicação pode contribuir para dar clareza ao conceito de negócios sociais.

Do ponto de vista da comunicação com os públicos, a noção de negócio de impacto é vaga e pouco elucidativa quanto aos propósitos dos negócios e, sobretudo, quanto ao alardeado impacto que são capazes de provocar na realidade social. Verificamos, tanto no Quintessa quanto nos negócios sociais consultados, pouca ênfase na comunicação de resultados sociais alcançados por estas organizações; suas ações de comunicação são centradas, majoritariamente, na divulgação de produtos e serviços e da tese de mudança do negócio.

Qual é o lugar dos negócios sociais entre as organizações contemporâneas? A literatura sobre negócios sociais reforça a importância das alianças intersetoriais para ampliar o impacto das soluções propostas pelos empreendedores para os problemas da sociedade. Porém, pouco se tem explorado - seja em âmbito acadêmico, seja entre os atores do ecossistema - o lugar de cada ator social (Estado, movimentos da sociedade civil, grandes corporações) neste cenário, o que seria ideal para cultivar relações de transparência entre as organizações e estabelecer uma comunicação mais esclarecedora com os públicos. A falta de precisão quanto ao lugar ocupado por cada ator social na resolução de problemas coletivos ajuda a explicar a pouca ênfase dada às alianças intersetoriais nos negócios consultados.

É preciso ainda olhar para esse contexto de forma mais ampla, observando as modificações nos processos produtivos das grandes empresas, resultado da pressão de grupos de interesse da sociedade civil, e as mudanças verificadas no terceiro setor, cujos profissionais têm migrado (com dificuldades) para o mercado tradicional, modificando suas práticas e sendo modificados por ele. Nesse sentido, buscamos refletir sobre um elemento comum a esses atores sociais que hoje fazem parte do mesmo ambiente no qual se inserem os negócios sociais: a sustentabilidade, ou, em nosso caso, a comunicação para a sustentabilidade. Partimos da seguinte questão: podem os ODS contribuir para a comunicação dos negócios sociais a fim de gerar sentidos sobre si - quanto à sua missão social - e para os seus públicos?

Observamos, em nosso estudo, que a compreensão da sustentabilidade pela sua dimensão ambiental ainda é muito forte no Quintessa e entre os negócios consultados. 
Predomina a visão de que os negócios sociais só seriam negócios sustentáveis se contemplassem, em sua missão, a resolução de um problema ambiental. Outro aspecto destacável é que, apesar do conhecimento sobre os ODS, os objetivos das Nações Unidas são pouco explorados na comunicação da aceleradora e dos negócios sociais. Sempre abordados superficialmente, os ODS foram apontados como um "entendimento inicial" do negócio social, em vez de um caminho possível para a solução de um problema da sociedade.

Uma possível explicação é a crítica feita ao fato de que toda a discussão sobre o cumprimento dos objetivos e metas das Nações Unidas contempla somente os Estados nacionais e as grandes empresas, negligenciando a potencial contribuição de pequenos e médios negócios para o desenvolvimento sustentável. Outro fator limitante da apropriação dos ODS pelos negócios sociais é, em nossa análise, a falta de comunicação dos resultados sociais alcançados pelos empreendedores, pouco mencionados no Quintessa e nos negócios analisados. Neste ponto, tais empreendimentos diferem-se das grandes empresas, que adotam modelos de relatórios de sustentabilidade amplamente divulgados para os seus públicos.

Em nosso estudo, procuramos compreender a comunicação dos negócios sociais sob uma filosofia de comunicação integrada, abrangendo as intencionalidades e efeitos do seu diálogo com seus públicos. Em primeiro lugar, quando nos referimos a uma comunicação integrada, de que tipo de integração estamos falando? Mais do que um exercício, a comunicação integrada é uma política e uma filosofia organizacionais cuja integração se dá pelas práticas discursivas, pelas estratégias de relacionamento com os públicos, pelo alinhamento aos objetivos de negócio e pelo planejamento e gestão de técnicas e instrumentos comunicacionais - que devem permear todas as dimensões da comunicação de um negócio social.

Ainda que na literatura, os negócios consultados e o Quintessa pareçam considerar impossível reproduzir modelos de negócios tradicionais, do ponto de vista da comunicação, sobretudo da filosofia da comunicação integrada, os negócios sociais ainda reproduzem práticas de empreendimentos tradicionais, com maior ênfase num discurso de vendas e no relacionamento com o "cliente". A prática diária do mundo dos negócios sugere que os empreendedores sociais e o Quintessa acabaram por internalizar os jargões do mundo corporativo: o "cidadão" dá lugar ao "cliente", a "solução social" dá lugar à "venda", a "mobilização social" dá lugar à "geração de leads". Assim, se pelo referencial teórico a 
comunicação de negócios sociais parece convergir para uma noção de comunicação comunitária - uma das premissas iniciais deste estudo -, pela pesquisa empírica emergem os pontos de divergência entre os dois: os negócios sociais consultados nesta pesquisa, em termos de técnicas e táticas comunicacionais, parecem mais próximos de empresas com práticas de responsabilidade social corporativa, ou seja, mais perto dos negócios tradicionais e mais distantes de organizações do terceiro setor.

Do ponto de vista da comunicação, a necessidade dos negócios sociais de pensar e agir diferente, tal qual preconizam Fischer e Comini (2012), parece ainda não acontecer. Com ênfase na lógica de mercado em detrimento de uma lógica social, os negócios sociais se aproximam daqueles tradicionais, sendo, sim, capazes de gerar "excelentes cases", para usar a expressão de um dos entrevistados, mas sem causar o impacto social desejado.

Dessa forma, predomina a comunicação mercadológica entre as dimensões da comunicação integrada identificadas nos negócios sociais analisados e no Quintessa premissa deste estudo confirmada pela pesquisa empírica. Quando abordada nos programas de aceleração, por exemplo, a comunicação é tomada quase como sinônimo de comunicação mercadológica e tratada como possível solução para um problema de vendas. Nos negócios analisados, observamos também o alinhamento acentuado entre a comunicação institucional e a mercadológica, sempre sob as diretrizes de uma área de marketing, exceto pelo negócio vinculado à base da pirâmide, que mantém estratégias e objetivos distintos para a comunicação institucional e para a comunicação mercadológica.

Há poucas referências à comunicação administrativa dos negócios sociais, dimensão que, avaliamos, deve ganhar especial atenção nos estágios iniciais dos negócios sociais, em consonância com o desenvolvimento do plano de negócios, em que são discutidos, analisados e testados fluxos, redes e processos produtivos com o objetivo de viabilizar um modelo de negócios sustentável. Ainda que receba menos investimentos que a comunicação mercadológica e institucional, a comunicação interna, por sua vez, é verificada na proposta de valor dos negócios analisados, a fim de atrair e reter talentos identificados com o propósito organizacional.

Outra questão contemplada por este estudo foi a reflexão sobre uma possível contribuição da filosofia da comunicação integrada para a aceleração dos negócios sociais. Observamos que a comunicação é item pouco abordado nos programas de aceleração do 
Quintessa, o que é justificado pela aceleradora com motivações diversas: falta de tempo do empreendedor, falta de recursos para investir em comunicação, falta de visão do empreendedor quanto ao valor estratégico da comunicação para o negócio, opção do programa por tratar aspectos considerados mais urgentes para o estágio em que o negócio se encontra etc. Em todos os negócios sociais analisados, porém, a comunicação, ainda que subordinada a uma área de marketing, é apontada como elemento importante para o impacto social do empreendimento.

A aparente dicotomia entre aceleradora e negócios acelerados faz emergir uma reflexão - ainda pouco trabalhada nos estudos de comunicação organizacional - quanto ao estágio do negócio no qual a comunicação passa a ser considerada do ponto de vista da estratégia de negócio. Entre os entrevistados, o modelo comunicacional das grandes empresas é considerado caro para negócios em estágios iniciais, fazendo com que a comunicação seja abordada pelos negócios após a aceleração, nos estágios de tração e escala. Também deve ser considerada na abordagem dos programas de aceleração do Quintessa para a comunicação nos negócios sociais a maneira como a própria comunicação da aceleradora acontece de forma reativa e ainda improvisada, sem planejamento estratégico.

Em nossa análise, a comunicação, por si só, não é capaz de conciliar objetivos financeiros e sociais dos empreendimentos - próprio das etapas iniciais de concepção dos negócios sociais -, mas é capaz de dar forma e sentido a eles. Além disso, em meio à grande oferta de instrumentos comunicacionais disponíveis, uma filosofia da comunicação integrada atua como um facilitador para o empreendedor social nos estágios iniciais do negócio, permitindo-lhe constituir um desenho estratégico da comunicação para o dia a dia da organização.

Buscamos ainda identificar e analisar, em níveis estratégico, tático e operacional, práticas e técnicas de comunicação adotadas pelos negócios sociais. A etapa de pesquisa empírica deste estudo observou, entre os negócios acelerados e o Quintessa, um entendimento da comunicação ligada a aspectos táticos e operacionais, a fim de gerar novas parcerias comerciais e atrair clientes. Além disso, nos negócios sociais analisados, os empreendedores sociais afirmaram que a comunicação está relacionada às estratégias de negócio e à tomada de decisões, porém sob uma lógica de mercado em vez de uma lógica social, no sentido posto por Comini (2016). 
Outra característica da comunicação dos negócios sociais observada neste estudo é seu baixo alcance de públicos potenciais, desejados pelos empreendedores sociais consultados. A "bolha" do ecossistema de negócios sociais é mencionada por mais de um entrevistado neste estudo como uma espécie de empecilho para atingir um impacto social maior. O pensamento inverso a essa proposta parece mais efetivo em termos de mudança social: ao invés de se ajustar a uma lógica de mercado, melhor opção não seria fazer a "bolha" crescer e estimular outros públicos a integrar o ecossistema de negócios sociais?

Reconhecidamente bem-sucedidos no nicho, os negócios sociais consultados e o Quintessa querem ampliar seu número de interlocutores. Contudo, não parecem ter um direcionamento muito claro de quem são eles e quais são as suas demandas e expectativas. As respostas dos entrevistados vagam entre "grandes empresas" e "clientes", numa relação quase sempre de intenção comercial, mas que exige uma mudança comportamental. Em nossa avaliação, é necessário que os negócios sociais ampliem sua noção de públicos, hoje restritos à cadeia produtiva, para pensar em uma comunicação planejada, estratégica e diversificada com outros públicos do ambiente em que estão inseridos, o que pode fazer surgir oportunidades mais diversificadas e com potencial de impacto para os negócios sociais.

Por fim, a comunicação integrada pode colaborar efetivamente com os negócios sociais e seu relacionamento com os públicos, no sentido de responder aos problemas sociais, ampliando o alcance de suas ações para além de um relacionamento entre cliente e empresa. Difere, portanto, de uma lógica de mercado adotada pelos empreendimentos sociais nas suas práticas de comunicação e cujos efeitos são sentidos no impacto social que o negócio quer provocar. A comunicação de impacto social é, sobretudo, transformadora de pessoas, de organizações, de Estados, do planeta. 


\section{REFERÊNCIAS}

$2^{\circ}$ MAPA de negócios de impacto social + ambiental. São Paulo: Pipe Social, 2019.

4YOU2 Idiomas: uma nova maneira de aprender inglês. 4YOU2 Idiomas, São Paulo, c2019. Disponível em: https://bit.ly/2NXv7eO. Acesso em: 8 nov. 2019.

ABRAMOVAY, R. Muito além da economia verde. São Paulo: Abril, 2012.

ABRAMOVAY, R. Desenvolvimento sustentável, valores éticos e visões de mundo. Valor Econômico, São Paulo, $1^{\circ}$ dez. 2015. Disponível em: https://bit.ly/2mTb5sc. Acesso em: 25 abr. 2018.

ALTER, K. Social enterprise typology. Ahmedabad: Virtue Ventures, 2007. Disponível em: https://bit.ly/2IWHx4B. Acesso em: 28 jul. 2019.

AMPARO, G. A. do; SILVA, R. B. da. Relações públicas comunitárias: qual o papel na intermediação entre a comunidade e as empresas privadas?. UNISANTA Law and Social Science, São Paulo, v. 4, n. 1, p. 78-93, 2015.

ANDRADE, C. T. S. Para entender relações públicas. São Paulo: Loyola, 1993.

ARANHA, A. Como estimular a expansão dos negócios de impacto. [Entrevista concedida a] Portal Notícias de Impacto. Notícias de Impacto, [S. l.], 30 maio 2018. Disponível em: https://bit.ly/2MGeKCo. Acesso em: 14 jul. 2019.

ASPEN NETWORK OF DEVELOPMENT ENTREPRENEURS; LGT VENTURE PHILANTHROPY; QUINTESSA PARTNERS; UNIVERSITY OF ST. GALLEN. Mapa do setor de investimento de impacto no Brasil: resumo das conclusões. [S.l.]: Ande, 2014. Disponível em: https://bit.ly/2MZRxLZ. Acesso em: 12 maio 2018.

AUSTIN, J. The collaboration challenge: how nonprofits and businesses succeed through strategic alliances. São Francisco: Jossey-Bass, 2002.

AUSTIN, J.; STEVENSON, H.; WEI-SKILLERN, J. Social and commercial entrepreneurship: same, different, or both? Revista de Administração, São Paulo, v. 47, n. 3, p. 370-384, 2012. DOI 10.5700/rausp1055. Disponível em: https://bit.ly/35Gq8Hj. Acesso em: 12 jul. 2019.

BALDISSERA, R. A comunicação (re)tecendo a cultura da sustentabilidade em sociedades complexas. In: KUNSCH, M. M. K.; OLIVEIRA, I. L. (org.). A comunicação na gestão da sustentabilidade das organizações. São Caetano do Sul: Difusão, 2009. p. 33-55.

BARDIN, L. Análise de conteúdo. Lisboa: Edições 70, 2002. 
BARICHELLO, E. M. R. A autoria na elaboração de uma tese. In: MOURA, C. P.; LOPES, M. I. V. (org.). Pesquisa em comunicação: metodologias e práticas acadêmicas. Porto Alegre: EDIPUCRS, 2016. p. 129-150.

BARKI, E.; AGUIAR, L. Negócios com impacto social em grandes e pequenas empresas. In: BARKI, E.; IZZO, D.; TORRES, H.; AGUIAR, L. (org.). Negócios com impacto social no Brasil. São Paulo: Peirópolis, 2013. p. 65-81.

BARKI, E.; COMINI, G.; CUNLIFFE, A.; HART, S.; RAI, S. Social entrepreneurship and social business: retrospective and prospective research. Revista de Administração de Empresas, São Paulo, v. 55, n. 4, p. 380-384, 2015. DOI 10.1590/S0034-759020150402. Disponível em: https://bit.ly/31pH91I. Acesso em: 12 jul. 2019.

BATISTELLA, M. M.; MARCHIORI, M. O processo comunicacional e as práticas sustentáveis nas organizações. Organicom, São Paulo, v. 10, n. 18, p. 110-122, 2013. DOI 10.11606/issn.2238-2593.organicom.2013.139173. Disponível em: https://bit.ly/2oH5Mx7. Acesso em: 12 jul. 2019.

BATTILANA, J.; LEE, M. Advancing research on hybrid organizing: insights from the study of social enterprises. Academy of Management Annals, Briarcliff Manor, v. 8, n. 1, p. 397-441, 2014. DOI 10.5465/19416520.2014.893615. Disponível em: https://bit.ly/33JGkpd. Acesso em: 12 jul. 2019.

BOFF, L. Sustentabilidade: o que é - o que não é. Rio de Janeiro: Vozes, 2012.

BRAGA, J. L. A prática da pesquisa em comunicação: abordagem metodológica como tomada de decisões. E-compós, Brasília, DF, v. 14, n. 1, p. 1-33, 2011.

DOI 10.30962/ec.665. Disponível em: https://bit.ly/2BhwajJ. Acesso em: 25 abr. 2018.

BRAGA, J. L. Aprender metodologia ensinando pesquisa: incidências mútuas entre metodologia pedagógica e metodologia científica. In: MOURA, C. P.; LOPES, M. I. V. (org.). Pesquisa em comunicação: metodologias e práticas acadêmicas. Porto Alegre: EdiPUCRS, 2016. p. 77-98.

BRANDÃO, D.; CRUZ, C.; ARIDA, A. L. Métricas em negócios de impacto social: fundamentos. São Paulo: Move: ICE, [2014]. Disponível em: https://bit.ly/32ye350. Acesso em: $1^{\circ}$ maio 2018.

BRASIL. Ministério das Relações Exteriores. Objetivos de desenvolvimento sustentável (ODS). Brasília, DF, [201-]. Disponível em: https://bit.ly/1X4myxq. Acesso em: 16 jul. 2019.

BRASIL. Presidência da República. Decreto no ${ }^{\circ}$.892, de 27 de outubro de 2016. Cria a Comissão Nacional para os Objetivos de Desenvolvimento Sustentável. Diário Oficial da União, Brasília, DF, 31 out. 2016. 
BRITISH COUNCIL; SOCIAL ENTERPRISE UK. Think global, trade local: how business with a social purpose can deliver more sustainable development. [S. l.]: British Council: Social Enterprise UK, 2015. Disponível em: https://bit.ly/1SieKa6. Acesso em: 16 jul. 2019.

BRITO, D. Empreendedorismo de impacto social cresce no Brasil. Agência Brasil, Brasília, DF, 16 jul. 2018. Disponível em: https://bit.ly/2uqIV8A. Acesso em: 16 jul. 2019.

BUENO, W. C. Comunicação e gestão empresarial: cenários contemporâneos.

Communicare, São Paulo, v. 2, n. 1, p. 83-91, 2002. Disponível em: https://bit.ly/2MPX33v. Acesso em: 29 abr. 2018.

BUENO, W. C. As transgressões conceituais em Comunicação Empresarial. Organicom, São Paulo, ed. esp., n. 11-12, p. 121-127, 2009. Disponível em: http://bit.ly/3411HmR. Acesso em: 15 nov. 2019.

BUENO, W. C. A importância da comunicação para a sustentabilidade. Educação para a Sustentabilidade, São Paulo, 8 out. 2011. Disponível em: https://bit.ly/2qo534f. Acesso em: 29 abr. 2018.

CASALI, A. M. Comunicação integrada e novas tecnologias de informação. In: CONGRESO LATINOAMERICANO DE INVESTIGADORES DE LA COMUNICACIÓN, 6., 2002, Santa Cruz de la Sierra. Anais [...]. Santa Cruz de La Sierra: Alaic, 2002. Disponível em: https://bit.ly/2OZ3nZc. Acesso em: 23 jun. 2019.

CERIDONO, J. Projetos novos a caminho e, como sempre, de um jeito inovador! [Entrevista concedida a] Camila Freitas. Notícias Eniac, [Guarulhos], 27 maio 2019. Disponível em: https://bit.ly/2MQJC3h. Acesso em: 14 jul. 2019.

CÉSAR, R. E. Movimentos sociais, comunidade e cidadania. In: KUNSCH, M. M. K.; KUNSCH, W. L. (org.). Relações públicas comunitárias: a comunicação em uma perspectiva dialógica e transformadora. São Paulo: Summus, 2007. p. 78-91.

COMINI, G. M. Negócios sociais e inclusivos: um panorama da diversidade conceitual. São Paulo: Ashoka Brasil: Instituto Walmart, 2011. (Série Mapa de Soluções Inovadoras: Tendências de Empreendedores na Construção de Negócios Sociais e Inclusivos). Disponível em: https://bit.ly/2MRfLrC. Acesso em: 25 abr. 2019.

COMINI, G. M. Negócios sociais e inovação social: um retrato de experiências brasileiras. 2016. 166 f. Tese (Livre-docência em Administração) - Faculdade de Economia, Administração e Contabilidade, Universidade de São Paulo, São Paulo, 2016.

COMINI, G. M.; BARKI, E.; AGUIAR, L. A three-pronged approach to social business: a Brazilian multi-case analysis. Revista de Administração, São Paulo, v. 47, n. 3, p. 385397, 2012. DOI 10.1590/S0080-21072012000300004. Disponível em: https://bit.ly/32sf6mX. Acesso em: 25 jul. 2019. 
COMINI, G. M.; BARKI, E.; AGUIAR, L. O novo campo dos negócios com impacto social. In: BARKI, E.; IZZO, D.; TORRES, H. G.; AGUIAR, L. (org.). Negócios com impacto social no Brasil. São Paulo: Peirópolis, 2013. p. 41-64.

COMINI, G. M.; FISCHER, R. M. (org.). Lições da prática: reflexões sobre os elos entre organizações da sociedade civil e negócios de impacto socioambientais. [São Paulo]: Ashoka, [2017]. Disponível em: https://bit.ly/2huorYY. Acesso em: 12 jul. 2019.

CONSELHO EMPRESARIAL BRASILEIRO PARA O DESENVOLVIMENTO SUSTENTÁ VEL. Guia de comunicação e sustentabilidade. São Paulo: CEBDS, 2010. Disponível em: https://bit.ly/2pCeI6E. Acesso em: 25 abr. 2018.

COX, R. Environmental communication and the public sphere. 2. ed. Thousand Oaks: Sage, 2010.

DATT, F. "Coworkings de nicho" viram alternativa para quem não quer uma sede própria. 8 jan. 2019. Pequenas empresas \& grandes negócios. Disponível em: https://glo.bo/2NONO5s. Acesso em: 23 jun. 2019.

DAVIDSON, A.; EDENS, G.; ROCHA, R.; PARKINSON, R.; LALL, S.; COSTA, T.; BOMBARDI, F.; HAMRA, S. O panorama das aceleradoras e incubadoras no Brasil. [S. l.]: Ande: ICE, 2017. Disponível em: https://bit.ly/2FO1HxH. Acesso em: 12 maio 2018.

DAVIDSON, A.; ROCHA, R. (org.). Panorama do setor de investimento de impacto no Brasil: resultados de mercado 2016 \& 2017. [S. l.]: Ande: Lavca, 2018. Disponível em: https://bit.ly/2VM3Teq. Acesso em: 12 jul. 2019.

DEES, J. G. The meaning of "social entrepreneurship". Duke Innovation and Entrepreneurship, Durham, 31 out. 1998. Disponível em https://bit.ly/2VSsqyD. Acesso em: 25 abr. 2018.

DEETZ, S. A ascensão dos modelos de governança dos stakeholders e o consequente redesenho da comunicação. In: KUNSCH, M. M. K.; OLIVEIRA, I. L. (org.). A comunicação na gestão da sustentabilidade das organizações. São Caetano do Sul: Difusão, 2009, p. 85-106.

DEETZ, S. Entrevista: Prof. Stanley Deetz "Estamos limitando soluções criativas". [Entrevista concedida a] Tatiana Maia Lins. Revista da Reputação, Rio de Janeiro, 28 jul. 2017. Disponível em: https://bit.ly/35QoDGK. Acesso em: 30 jul. 2019.

DUARTE, J. Entrevista em profundidade. In: DUARTE, J.; BARROS, A. (org.). Métodos e técnicas de pesquisa em comunicação. São Paulo: Atlas, 2005. p. 62-83.

DUMONT, K.; EDENS, G.; MARIZ, F.; ROCHA, R.; ROMAN, E.; ROSSI, A.; VALENCIA, N. The impact investing landscape in Latin America: trends 2014 \& 2015: special focus on Brazil, Colombia \& Mexico. [S. l.]: Ande, 2016. Disponível em: https://bit.ly/2Gueh4q. Acesso em: 12 jul. 2019. 
EIROA, C. Com impacto, por favor. Revista Trip, São Paulo, 25 set. 2018. Disponível em: https://bit.ly/2pzWSRM. Acesso em: 17 jul. 2019.

ELKINGTON, J. Sustentabilidade: canibais com garfo e faca. São Paulo: M. Books, 2011.

ENDEAVOR INSIGHT. Criando uma rede de empreendedores sociais: uma análise do ecossistema empreendedor para os negócios sociais em São Paulo. [S. l.]: Endeavor, 2016. Disponível em: https://bit.ly/33Hiyu5. Acesso em: 25 abr. 2018.

ESPM SOCIAL. Pesquisa de marketing e comunicação: negócios de impacto social. São Paulo: ESPM, 2019.

FARIAS, L. A.; PENAFIERI, V.; MIANO, B. O storytelling como estratégia das relações públicas para a promoção da humanização. In: ROMANCINI, R.; LOPES, M. I. V. (org.). CONGRESSO IBERO-AMERICANO DE COMUNICAÇÃO, 14., 2015, São Paulo. Anais [...]. São Paulo: ECA-USP, 2015. p. 5300-5310. Disponível em: https://bit.ly/2DAP9tq. Acesso em: 26 jul. 2019.

FELIZOLA, M. P. M.; CABRAL, A. C.; SANTOS, G. M.; SANTOS, V. L.; SANTOS, T. O. R. dos; OLIVEIRA, R. C. R. de. Comunicação organizacional integrada: em busca de um conceito. In: CONGRESSO BRASILEIRO DE CIÊNCIAS DA COMUNICAÇÃO, 32, 2009, Curitiba, PR. Anais [...]. Curitiba, PR: Intercom, 2009. Disponível em: http://bit.ly/2XgnaW6. Acesso em: 16 jul. 2019.

FERNANDES, B. R. Planejamento estratégico de comunicação para o licenciamento ambiental no estado de São Paulo. 2014. 247 f. Tese (Doutorado em Ciências da Comunicação) - Escola de Comunicações e Artes, Universidade de São Paulo, São Paulo, 2014.

FISCHER, R. M. Networks, terceiro setor e desenvolvimento social: a construção de um banco interativo de projetos sociais na Amazônia Legal. Revista de Administração, São Paulo, v. 36, n. 3, p. 28-35, 2001. Disponível em: https://bit.ly/2nZG0n9. Acesso em: 8 maio 2018.

FISCHER, R. M. O desafio da colaboração: práticas de responsabilidade social entre empresas e terceiro setor. São Paulo: Gente, 2002.

FISCHER, R. M. Estado, mercado e terceiro setor: uma análise conceitual das parcerias intersetoriais. Revista de Administração, São Paulo, v. 40, n. 1, p. 5-18, 2005. Disponível em: https://bit.ly/NDdnUC. Acesso em: 8 maio 2018.

FISCHER, R. M. Agenda social no Brasil. In: JUNQUEIRA, L. A. P.; GONÇALVES DIAS, S. L. F.; WANDERLEY, M. B.; MENDONÇA, P. (org.). Gestão social: mobilizações e conexões. São Paulo: LCTE Editora, 2012. v. 6. p. 280-285. Disponível em: https://bit.ly/2VVWn0L. Acesso em: 8 maio 2018. 
FISCHER, R. M.; COMINI, G. Sustainable development: from responsibility to entrepreneurship. Revista de Administração, São Paulo, v. 47, n. 3, p. 363-369, 2012. DOI 10.1590/S0080-21072012000300002. Disponível em: https://bit.ly/2Bu1lZa. Acesso em: 30 jul. 2019.

FONSECA, M. Coworking descolado dispensa funcionária grávida e gera revolta. Exame, São Paulo, 10 dez. 2018. Disponível em: https://bit.ly/32ynAsE. Acesso em: 17 jul. 2019.

FORÇA TAREFA DE FINANÇAS SOCIAIS. Carta de princípios para negócios de impacto no Brasil. São Paulo: ICE: Sitawi Finanças do Bem, 2015a. Disponível em: https://bit.ly/2NJBWQG. Acesso em: 16 jul. 2019.

FORÇA TAREFA DE FINANÇAS SOCIAIS. Finanças sociais: soluções para desafios sociais e ambientais: uma nova mentalidade para gerenciar recursos e necessidades da sociedade. São Paulo: ICE: Sitawi Finanças do Bem, 2015b. Disponível em: https://bit.ly/35REULi. Acesso em: 16 jul. 2019.

FORÇA TAREFA DE FINANÇAS SOCIAIS. Avanço das recomendações e reflexões para o fortalecimento das finanças sociais e negócios de impacto no Brasil: relatório 2016. São Paulo: ICE; Sitawi Finanças do Bem, 2016. Disponível em: https://bit.ly/31Amawp. Acesso em: 2 maio 2018.

FRANÇA, F. Subsídios para o estudo do conceito de relações públicas no Brasil. Comunicação \& Sociedade, São Bernardo do Campo, v. 24, n. 39, p. 127-154, 2003. DOI 10.15603/2175-7755/cs.v24n39p127-154. Disponível em: https://bit.ly/2Bv8JmU. Acesso em: 30 jul. 2019.

FRANÇA, F. A classificação dos stakeholders. 2010. 52 slides. Disponível em: https://bit.ly/2QeHp6d. Acesso em: 17 jul. 2019.

FRANÇA, F. Públicos: como identificá-los em nova visão estratégica. 3. ed. São Caetano do Sul: Yendis, 2012.

FRANÇA, F.; FERRARI, M. A. Reflexões sobre uma nova proposta de classificação da comunicação e de suas áreas. In: CONGRESSO BRASILEIRO CIENTÍFICO DE COMUNICAÇÃO ORGANIZACIONAL E RELAÇÕES PÚBLICAS, 2., 2008, Belo Horizonte. Anais [...]. Belo Horizonte: Abrapcorp, 2008. Disponível em: https://bit.ly/2pyA7Oq. Acesso em: 16 jul. 2019.

FREITAS, W. R. S.; JABBOUR, C. J. C. Utilizando estudo de caso(s) como estratégia de pesquisa qualitativa: boas práticas e sugestões. Estudo \& Debate, Lajeado, v. 18, n. 2, p. 722, 2011. Disponível em: https://bit.ly/31wqDjV. Acesso em: 28 jun. 2019.

GERALDES, E. C. Os blogs de notícias e a possibilidade de reconstituição da esfera pública. Comunicologia, Brasília, DF, v. 2, n. 1, p. 43-56, 2009. DOI 10.24860/comunicologia.v2i1.1269. Disponível em: https://bit.ly/2J3XWV2. Acesso em: 16 jul. 2019. 
GERALDES, E. C. Política de comunicação nas organizações: a terceira esfera. In: FORMIGA SOBRINHO, A. B. (org.). Muito além dos meios: comunicação organizacional, desafios e interfaces. Brasília: Editora UnB, p.130-138, 2014

GLOBAL REPORTING INITIATIVE; UNITED NATIONS GLOBAL COMPACT; WORLD BUSINESS COUNCIL FOR SUSTAINABLE DEVELOPMENT. Guia dos ODS para as empresas: diretrizes para implementação dos ODS na estratégia dos negócios. [S. l.]: GRI, [2015]. Disponível em: https://bit.ly/33KpIhg. Acesso em: 23 jul. 2019.

GLOBESCAN; SUSTAINABILITY. The 2018 GlobeScan-SustainAbility leaders survey. [S. l.]: GlobeScan: SustainAbility, 2018. Disponível em: https://bit.ly/2thWbL6. Acesso em: 17 jul. 2019.

GODOY, A. S. Pesquisa qualitativa: tipos fundamentais. Revista de Administração de Empresas, São Paulo, v. 35, n. 3, p. 20-29, 1995. Disponível em: https://bit.ly/31s15Xv. Acesso em: 16 jul. 2019.

GONÇALO JUNIOR. O quinto elemento. Capital Aberto, São Paulo, 14 jan. 2018. Disponível em: https://bit.ly/33LV7jf. Acesso em: 14 jul. 2019.

GONÇALVES, C. E. A. Negócios sociais e investimentos de impacto: um estudo sobre as percepções dos atores do ecossistema. 2017. 232 f. Dissertação (Mestrado em Ciências) Faculdade de Economia, Administração e Contabilidade, Universidade de São Paulo, São Paulo, 2017.

GONÇALVES, C. A.; BORGES, F. R. F.; SOUZA, G. F. M.; RIBEIRO, J. A. Aliando o bom desempenho empresarial ao desenvolvimento sustentável: um estudo sob a ótica das perspectivas ambiental, social, econômica e da governança corporativa. In: KEINERT, T. M. M. (org.). Organizações sustentáveis: utopias e inovações. São Paulo: Annablume, 2007, p. 131-143.

GRUNIG, J. E. Guia de pesquisa e medição para elaborar e avaliar uma função excelente de relações públicas. Organicom, São Paulo, v. 2, n. 2, p. 47-69, 2005.

DOI 10.11606/issn.2238-2593.organicom.2005.138881. Disponível em: https://bit.ly/2MAsIqV. Acesso em: 23 jul. 2019.

GRUNIG, J. E.; FERRARI, M. C.; FRANÇA, F. Relações públicas: teoria, contexto e relacionamentos. São Caetano do Sul: Difusão, 2009.

GRUNIG, J. E.; HUNT, T. Managing public relations. New York: CBS College Publishing, 1984.

HENRIQUES, M. S. Ativismo, movimentos sociais e relações públicas. In: KUNSCH, M. M. K.; KUNSCH, W. L. (org.). Relações públicas comunitárias: a comunicação em uma perspectiva dialógica e transformadora. São Paulo: Summus, 2007. p. 92-104. 
HERDY, T. Coworking da moda de São Paulo, CIVI-CO dispensa recepcionista grávida na véspera do parto. Época, [s. l.], 4 dez. 2018. Disponível em: https://glo.bo/2J7Lync. Acesso em: 17 jul. 2019.

HERRERA, R. N. Relações públicas na perspectiva do empreendedorismo social. In: CONGRESSO BRASILEIRO DE PESQUISADORES EM COMUNICAÇÃO ORGANIZACIONAL E RELAÇÕES PÚBLICAS, 6., 2012, São Luís. Anais [...]. São Luís: Abrapcorp, 2012.

KERLIN, J. A. Social enterprise in the United States and Europe: understanding and learning from the differences. Voluntas, Baltimore, v. 17, p. 247-263, 2006.

DOI 10.1007/s11266-006-9016-2. Disponível em: https://bit.ly/2VX4cmE. Acesso em: 17 jul. 2019.

KISCHINHEVSKY, M. Métodos de pesquisa qualitativa aplicada à comunicação radiofônica. In: MOURA, C. P.; LOPES, M. I. V. (org.). Pesquisa em comunicação: metodologias e práticas acadêmicas. Porto Alegre: EDIPUCRS, 2016. p. 277-294.

KIYAMA, R. S.; COMINI, M. G.; D’AMARIO, E. Q. Criação de negócios sociais no Brasil: um estudo exploratório. In: ENCONTRO DA ASSOCIAÇÃO NACIONAL DE PÓS-GRADUAÇÃO E PESQUISA EM ADMINISTRAÇÃO, 38., 2014, Rio de Janeiro. Anais [...]. Maringá: Anpad, 2014. Disponível em: http://bit.ly/356MZdX. Acesso em: 25 abr. 2018.

KUNSCH, M. M. K. Relações públicas e modernidade: novos paradigmas na comunicação organizacional. 3. ed. São Paulo: Summus, 1997.

KUNSCH, M. M. K. Comunicação organizacional no Brasil: panorama histórico e perspectivas. In: Laboratório Integrado de Marketing e Cultura (org.). Políticas de comunicação corporativa. São Paulo: Com-Arte, 2005, p. 11-31.

KUNSCH, M. M. K. Planejamento e gestão estratégica de relações públicas nas organizações contemporâneas. Anàlisi, Barcelona, v. 34, p. 125-139, 2006. Disponível em: https://bit.ly/2pC7vnr. Acesso em: 23 jun. 2019.

KUNSCH, M. M. K. Comunicação organizacional na era digital: contextos, percursos e possibilidades. Signo y Pensamiento, Bogotá, v. 26, n. 51, p. 38-51, 2007a. Disponível em: https://bit.ly/2YCm321. Acesso em: 30 jun. 2019.

KUNSCH, M. M. K. Dimensões e perspectivas das relações públicas comunitárias. In: KUNSCH, M. M. K.; KUNSCH, W. L. (org.). Relações públicas comunitárias: a comunicação em uma perspectiva dialógica e transformadora. São Paulo: Summus, 2007 b. p. $165-180$.

KUNSCH, M. M. K. Planejamento e gestão estratégica das relações públicas comunitárias. In: KUNSCH, M. M. K.; KUNSCH, W. L. (org.). Relações públicas comunitárias: a 
comunicação em uma perspectiva dialógica e transformadora. São Paulo: Summus, 2007c. p. 293-309.

KUNSCH, M. M. K. A comunicação para a sustentabilidade organizacional na sociedade global. In: KUNSCH, M. M. K.; OLIVEIRA, I. L. (org.). A comunicação na gestão da sustentabilidade das organizações. São Caetano do Sul: Difusão, 2009. p. 57-81.

KUNSCH, M. M. K. As dimensões humana, instrumental e estratégica da Comunicação Organizacional: recorte de um estudo aplicado no segmento corporativo. Intercom: Revista Brasileira de Ciências da Comunicação, São Paulo, v. 35, n. 2, p. 267-289, 2012. DOI 10.1590/S1809-58442012000200014. Disponível em: https://bit.ly/2VWJALk. Acesso em: 25 jul. 2019.

KUNSCH, M. M. K. A comunicação na gestão da sustentabilidade em organizações brasileiras. Revista Mediterránea de Comunicacion, Sant Vicent del Raspeig, v. 6, n. 2, p. 1-33, 2015. DOI 10.14198/MEDCOM2015.6.2.02. Disponível em: https://bit.ly/2pRV9b3. Acesso em: 30 jul. 2019.

KUNSCH, M. M. K. Planejamento de relações públicas na comunicação integrada. 6 . ed. São Paulo: Summus, 2016.

KUNSCH, M. M. K.; MOYA, I. M. S. Políticas e estratégias de comunicação na gestão da sustentabilidade nas organizações públicas e privadas: principais resultados da pesquisa empírica. In: CONGRESO LATINOAMERICANO DE INVESTIGADORES DE LA COMUNICACIÓN, 12., 2014, Lima. Anais [...]. Lima: Alaic: PUCP, 2014. Disponível em: https://bit.ly/35Tmjyn. Acesso em: 25 abr. 2018.

KUNSCH, W. L. Resgate histórico das relações públicas comunitárias no Brasil. In: KUNSCH, M. M. K.; KUNSCH, W. L. (org.). Relações públicas comunitárias: a comunicação em uma perspectiva dialógica e transformadora. São Paulo: Summus, 2007. p. 107-123.

LAKATOS, E. M.; MARCONI, M. A. Fundamentos de metodologia científica. 5. ed. São Paulo: Atlas, 2003.

LEO Figueiredo: Trip Transformadores 2017. [S. l.: s. n.], 14 dez. 2017. 1 vídeo (4 min, $41 \mathrm{~s})$. Publicado pelo canal Trip Transformadores. Disponível em: https://bit.ly/2J5GcZD. Acesso em: 14 jul. 2019.

LEUZINGER, B. O Quintessa promove a "gestão consciente" para impulsionar startups com propósito. Projeto Draft, [s. l.], 5 dez. 2018. Disponível em: https://bit.ly/2QDspym. Acesso em: 17 jul. 2019.

LIMEIRA, T. M. V. O papel das aceleradoras de impacto no desenvolvimento dos negócios sociais no Brasil: relatório de pesquisa. São Paulo: FGV EAESP, 2014. Disponível: https://bit.ly/2P5yp1I. Acesso em: 16 jul. 2019. 
LIRA, A. São Paulo ganha espaço compartilhado para negócios de impacto social. Revista Pequenas Empresas \& Grandes Negócios, [s. l.], $1^{\circ}$ nov. 2017. Disponível em: https://glo.bo/32ydvvY. Acesso em: 17 jul. 2019.

LOURENÇO, M. R.; MARCHIORI, M. Comunicação sustentável: um processo de construção da consciência dos sujeitos sobre sustentabilidade. In: CONGRESSO BRASILEIRO DE ESTUDOS ORGANIZACIONAIS, 1., 2013, Fortaleza. Anais [...]. Fortaleza: SBEO, 2013. Disponível em: https://bit.ly/2MWOFPV. Acesso em: 25 abr. 2018.

MALHOTRA, N. Pesquisa de marketing: uma orientação aplicada. 4. ed. Porto Alegre: Bookman, 2006.

MEDEIROS, D. C. V. Fundação Roberto Marinho: quando a "solidariedade" se transforma em construção de consensos e negócios sociais. 2018. $241 \mathrm{f}$. Tese (Doutorado em Comunicação) - Universidade Federal do Rio de Janeiro, Rio de Janeiro, 2018.

MEDRANO, J. A. V. Comunicação organizacional integrada: alicerce intrínseco da economia de comunhão. 2007. 265 f. Tese (Doutorado em Ciências da Comunicação) Escola de Comunicações e Artes, Universidade de São Paulo, São Paulo, 2007.

MOYA, I. M. S. Crítica do discurso da sustentabilidade global: a comunicação como estratégia possível. 2016. 259 f. Tese (Doutorado em Comunicação) - Escola de Comunicações e Artes, Universidade de São Paulo, São Paulo, 2016.

MOZZATO, A. R.; GRZYBOVSKI, D. Análise de conteúdo como técnica de análise de dados qualitativos no campo da administração: potencial e desafios. Revista de Administração Contemporânea, Curitiba, v. 15, n. 4, p. 731-747, 2011. DOI 10.1590/S1415-65552011000400010. Disponível em: https://bit.ly/2J9tBEz. Acesso em: 23 jun. 2019.

OLIVEIRA, C. Yunus Brasil cria braço para ajudar grandes empresas na área de negócios sociais. Revista Pequenas Empresas \& Grandes Negócios, [s. l.], 7 fev. 2019. Disponível em: https://glo.bo/2MWGRh4. Acesso em: 23 jun. 2019.

OLIVEIRA, R. B. Comunicação organizacional integrada na Universidade de Brasília: um estudo de caso. 2015. 183 f. Dissertação (Mestrado em Gestão Pública) - Universidade de Brasília, Brasília, DF, 2015.

OLIVEIRA, I. L.; PAULA, M. A. Componentes da comunicação estratégica: uma reflexão sobre a articulação entre os aspectos teórico-conceituais e práticos. In: CONGRESSO BRASILEIRO DE CIÊNCIAS DA COMUNICAÇÃO, 29., 2006, Brasília, DF. Anais [...]. Brasília, DF: Intercom, 2006. Disponível em: https://bit.ly/2N1Eyco. Acesso em: 16 jul. 2019.

OLIVEIRA, M. J. C.; NADER, S. M. Empreendedorismo social na interface entre comunicação pública e capital social. Organicom, São Paulo, v. 14, n. 26, p. 41-51, 2017. 
DOI 10.11606/issn.2238-2593.organicom.2017.139355. Disponível em: https://bit.ly/2P1vyGZ. Acesso em: 16 jul. 2019.

OLIVEIRA FILHO, G.; KIYAMA, R. S.; COMINI, G. Os desafios de mensurar impacto social. In: BARKI, E.; IZZO, D.; TORRES, H.; AGUIAR, L. (org.). Negócios com impacto social no Brasil. São Paulo: Peirópolis, 2013. p. 211-226.

O RETRATO atual do pipeline de impacto no Brasil. Pipe Social, São Paulo, 2019. Disponível em: https://bit.ly/2ByrB4K. Acesso em: 16 jul. 2019.

PALMERSTON, V. B.; AGUIAR, A.; COLLIER, A. C.; LAGARES, B.; LAMMARE, B.; ALVES, C. P.; ARAÚJO, D.; MORATO, F.; ARAÚJO, L. K.; OLIVEIRA, M. M.; BONOM, M.; ALVES, M.; CAMPOS, R. A prática da comunicação integrada nas organizações. In: CONGRESSO BRASILEIRO DE CIÊNCIAS DA COMUNICAÇÃO, 27.; ENCONTRO DOS NÚCLEOS DE PESQUISA DA INTERCOM, 4., 2004, Porto Alegre. Anais [...]. São Paulo: Intercom, 2004. Disponível em: https://bit.ly/2PjeQBb. Acesso em: 23 jun. 2019.

PEREIRA, E. L. I. A era pós-disciplinar e o ambiente contemporâneo de relações públicas: cosmovisão ampliada da disciplina. 2017. 195 f. Tese (Doutorado em Ciências da Comunicação) - Escola de Comunicações e Artes, Universidade de São Paulo, São Paulo, 2017.

PERUZZO, C. M. K. Relações públicas, movimentos populares e transformação social. Revista Brasileira de Comunicação, São Paulo, v. 16, n. 2, p. 1-10, 1993. Disponível em: https://bit.ly/2J9TrZb. Acesso em: 29 abr. 2018.

PERUZZO, C. M. K. Comunicação comunitária e gestão participativa. In: KUNSCH, M. M. K.; KUNSCH, W. L. (org.). Relações públicas comunitárias: a comunicação em uma perspectiva dialógica e transformadora. São Paulo: Summus, 2007. p. 137-149.

PORTER, M. E.; KRAMER, M. R. Creating shared value. Harvard Business Review, Brighton, v. 80, jan./fev. 2011. Disponível em: https://bit.ly/1yheDln. Acesso em: 16 jul. 2019.

PORTOCARRERO, F.; DELGADO, A. J. Negocios inclusivos y generación de valor social. In: MÁRQUEZ, P.; REFICCO, E.; BERGER, G. (ed.). Negocios inclusivos: iniciativas de mercado con los pobres de Iberoamérica. Washington, DC: Banco Interamericano de Desarrollo, 2010. p. 127-172.

PRAHALAD, C. K.; HART, S. L. The fortune at the bottom of the pyramid. Strategy + Business, New York, n. 26, 2002. Disponível em: https://bit.ly/2r16ap4. Acesso em: 12 maio 2018.

PROGRAMA DAS NAÇÕES UNIDAS PARA O DESENVOLVIMENTO.

Transformando Nosso Mundo: a Agenda 2030 para o Desenvolvimento Sustentável. 2016. Disponível em: http://bit.ly/2phBS2u. Acesso em: 25 jul. 2019. 
PROGRAMA DAS NAÇÕES UNIDAS PARA O DESENVOLVIMENTO. Iniciativa Incluir. 2019. Disponível em: https://bit.ly/2vwC0Ms. Acesso em: 25 jun. 2019.

PROGRAMA DAS NAÇÕES UNIDAS PARA O DESENVOLVIMENTO; FUNDAÇÃO DOM CABRAL. Mercados inclusivos no Brasil: desafios e oportunidades do ecossistema de negócios. [Brasília, DF]: PNUD: FDC, 2015. Disponível em: https://bit.ly/1L7mqrz. Acesso em: 16 jul. 2019.

PROGRAMA DAS NAÇÕES UNIDAS PARA O DESENVOLVIMENTO; SERVIÇO BRASILEIRO DE APOIO ÀS MICRO E PEQUENAS EMPRESAS. Retrato dos pequenos negócios inclusivos e de impacto no Brasil 2017. [Brasília, DF]: PNUD: SEBRAE, 2017. Disponível em: https://bit.ly/2MYDSVe. Acesso em: 25 jun. 2019.

QUEM somos. Quintessa, São Paulo, c2019. Disponível em: https://bit.ly/2JYbzFV. Acesso em: 7 nov. 2019.

QUER saber as tendências em CI para 2019? Ação Integrada, Curitiba, 14 jan. 2019. Disponível em: https://bit.ly/2nF6r19. Acesso em: 17 jul. 2019.

QUINTESSA. Somos Quintessa. 2019. (4min23s). Disponível em: http://bit.ly/2qZV9G4. Acesso em: 7 nov. 2019.

QUINTESSA. Guia 2.5: guia para o desenvolvimento de negócios de impacto. 2017. Disponível em: http://bit.ly/2KlWXAc. Acesso em: Acesso em: 25 jun. 2019.

REDE BRASIL DO PACTO GLOBAL; PROGRAMA DAS NAÇÕES UNIDAS PARA O DESENVOLVIMENTO. Rede Brasil do Pacto Global. Brasília, DF: Rede Brasil: PNUD 2019. Disponível em: https://bit.ly/33WjB9T. Acesso em: 25 jun. 2019.

REFICCO, E.; VERNIS, A. Ecosistemas organizacionales para fortalecer negocios inclusivos. In: MÁRQUEZ, P.; REFICCO, E.; BERGER, G. (ed.). Negocios inclusivos: iniciativas de mercado con los pobres de Iberoamérica. Washington, DC: Banco Interamericano de Desarrollo, 2010. p. 127-172.

RENAULT, C. S. Metrics for entrepreneurship centers: a guide for practitioners. Orlando: Inbia, 2017. Disponível em: https://bit.ly/33WIiD7. Acesso em: 16 jul. 2019.

RIBEIRO, S. A.; ANDRADE, R. M. G.; ZAMBALDE, A. L. Incubadoras de empresas, inovação tecnológica e ação governamental: o caso de Santa Rita do Sapucaí (MG).

Cadernos Ebape.BR, Rio de Janeiro, v. 3, p. 1-14, 2005. Número especial. DOI 10.1590/S1679-39512005000500010. Disponível em: https://bit.ly/32yGrEc. Acesso em: 22 out. 2019.

RODRIGUES, J. O movimento B Corp: significados, potencialidades e desafios. 2016. 217 f. Dissertação (Mestrado em Administração) - Faculdade de Economia, Administração e Contabilidade, Universidade de São Paulo, São Paulo, 2016. 
ROSOLEN, T.; TISCOSKI, G. P.; COMINI, G. M. Empreendedorismo social e negócios sociais: um estudo bibliométrico da publicação nacional e internacional. Revista Interdisciplinar de Gestão Social, Salvador, v. 3, n. 1, p. 85-105, 2014. DOI 10.9771/23172428rigs.v3i1.8994. Disponível em: https://bit.ly/32zPIvv. Acesso em: 16 jul. 2019.

ROXO, M. Metodologia como disciplina: estratégias pedagógicas adotadas em sala de aula. In: MOURA, C. P.; LOPES, M. I. V. (org.). Pesquisa em comunicação: metodologias e práticas acadêmicas. Porto Alegre: EDIPUCRS, 2016. p. 109-128.

SABBATINI, J. N. Uma tipologia possível para análise da comunicação organizacional. In: CONGRESSO BRASILEIRO CIENTÍFICO DE COMUNICAÇÃO ORGANIZACIONAL E RELAÇÕES PÚBLICAS, 1., 2007, São Paulo. Anais [...]. São Paulo: Abrapcorp, 2007. Disponível em: https://bit.ly/32FjHSU. Acesso em: 23 jun. 2019.

SABBATINI, J. F. Comunicação organizacional e governança corporativa: uma intersecção possível? 2010. 214 f. Tese (Doutorado em Ciências da Comunicação) - Escola de Comunicações e Artes, Universidade de São Paulo, São Paulo, 2010.

SCHELLER, F. Os jornais como investimento de impacto social. O Estado de S.Paulo, São Paulo, 11 mar. 2019. Economia \& Negócios. Disponível em: https://bit.ly/2JcvyjF. Acesso em: 23 jun. 2019.

SCROFERNEKER, C. M. A. Trajetórias teórico-conceituais da comunicação organizacional. Revista Famecos, Porto Alegre, v. 13, n. 31, p. 47-53, 2006.

DOI 10.15448/1980-3729.2006.31.3392. Disponível em: https://bit.ly/2OWuVuw. Acesso em: 30 jul. 2019.

SERVIÇO BRASILEIRO DE APOIO ÀS MICRO E PEQUENAS EMPRESAS. Diretrizes estratégicas para atuação do Sistema SEBRAE no mercado de negócios sociais. Brasília, DF: SEBRAE, 2013. Disponível em: https://bit.ly/2MZ9Kck. Acesso em: 16 jul. 2019.

SERVIÇO BRASILEIRO DE APOIO ÀS MICRO E PEQUENAS EMPRESAS.

Diretrizes estratégicas: o SEBRAE no atendimento aos negócios de impacto social: versão 2.0. Brasília, DF: SEBRAE, 2016. Disponível em: https://bit.ly/32C0Ubc. Acesso em: 16 jul. 2019.

SOCIAL ENTERPRISE KNOWLEDGE NETWORK. Gestión efectiva de emprendimientos sociales. Washington, DC: Banco Interamericano de Desarrollo, 2006.

SELLTIZ, C.; WRIGHTSMAN, L. S.; COOK, S. W. Métodos de pesquisa nas relações sociais. 5. ed. São Paulo: EPU: Edusp, 1975.

SEN, A. Desenvolvimento como liberdade. São Paulo: Companhia das Letras, 2010. 
SILVA, A. H.; FOSSÁ, M. I. T. Análise de conteúdo: exemplo de aplicação da técnica para análise de dados qualitativos. Qualit@s, Campina Grande, v. 16, n. 1, p. 1-14, 2015. DOI 10.18391/qualitas.v16i1.2113. Disponível em: https://bit.ly/31BOCOO. Acesso em: 16 jul. 2019.

SILVA, A. P. A.; GONÇALVES-DIAS, S. L. F. Mensuração de desempenho socioambiental: estudo de casos em negócios sociais brasileiros. Pensamento e Realidade, São Paulo, v. 30, n. 2, p. 117-151, 2015. Disponível em: https://bit.ly/360p94L. Acesso em: $1^{\circ}$ maio 2018.

SILVA, M. P.; GUEDES, E. N.; SANTOS, P. C. Conscientização e participação: as relações públicas comunitárias na construção da cidadania. Organicom, São Paulo, v. 14, n. 26, p. 87-98, 2017. DOI 10.11606/issn.2238-2593.organicom.2017.139359. Disponível em: https://bit.ly/32EiafX. Acesso em: 16 jul. 2019.

SILVA, M., GUEDES, E. Emergências da sociedade contemporânea: demandas sociais e a contribuição das relações públicas comunitárias no caso da Una C. Comunicação \& Mercado, Dourados, v. 5, n. 12, p. 7-19, jan-jun 2016.

SMITH, V. P. B. Comunicação, governança e sustentabilidade: como desenhos de interação influenciam o engajamento de empresas com stakeholders. 2015. 159 f. Tese (Doutorado em Ciências da Comunicação) - Escola de Comunicações e Artes, Universidade de São Paulo, São Paulo, 2015.

SMITH, W. K.; GONIN, M.; BESHAROV, M. L. Managing social business tensions: a review and research agenda for social enterprise. Business Ethics Quarterly, Cambridge, v. 23, n. 3, p. 1-53, 2013. DOI 10.5840/beq201323327. Disponível em: https://bit.ly/2W5bW6c. Acesso em: 16 jul. 2019.

TORQUATO, G. Da gênese do jornalismo empresarial e das relações públicas à comunicação organizacional no Brasil. In: KUNSCH, M. M. K. (org.). Comunicação organizacional: histórico, fundamentos e processos. São Paulo: Saraiva, 2009.

TUZZO, S. A.; MAINIERI, T. Pesquisa empírica em comunicação organizacional e relações públicas: proposta metodológica e olhar sobre a prática de assessorias de comunicação em Goiás. Intercom: Revista Brasileira de Ciências da Comunicação, São Paulo, v. 34, n. 1, p. 233-252, 2011. DOI 10.1590/S1809-58442011000100012. Disponível em: https://bit.ly/2pMRzhW. Acesso em: 16 jul. 2019.

ULSEN, P. Comunicação para a Sustentabilidade em Organizações do Terceiro Setor. 2018. 500 f. Tese (Doutorado em Ciências da Comunicação) - Escola de Comunicações e Artes, Universidade de São Paulo, São Paulo, 2018.

VILAÇA, W. P. T. A comunicação interna na gestão da sustentabilidade: um estudo fenomenológico. 2012. 290 f. Tese (Doutorado em Ciências da Comunicação) - Escola de Comunicações e Artes, Universidade de São Paulo, São Paulo, 2012. 
XIFRA TRIADÚ, J. Lucien Matrat y la consolidación de las relaciones públicas en Europa. Revista Historia y Comunicación Social, Madrid, v. 11, p. 229-240, 2006. Disponível em: https://bit.ly/31GcH6S. Acesso em: 16 jul. 2019.

YANAZE, M. H.; FREIRE, O.; SENISE, D. Retorno de investimentos em comunicação: avaliação e mensuração. 2. ed. Rio de Janeiro: Difusão: Senac, 2013.

YIN, R. K. Estudo de caso: planejamento e métodos. 2. ed. Porto Alegre: Bookman, 2001.

YUNUS, M. O Banqueiro dos Pobres - A Evolução do Microcrédito que Ajudou os Pobres. São Paulo: Ática, 2000.

YUNUS, M. Credit for the poor: poverty as distant history. Harvard International Review, Cambridge, v. 29, n. 3, p. 20-24, 2007. Disponível em: https://bit.ly/2JfCGff. Acesso em: 2 maio 2018.

YUNUS, M. Seven principles of social business. Yunus Centre, Daca, c2011. Disponível em: https://bit.ly/35ToG4B. Acesso em: 25 jun. 2019. 


\section{APÊNDICES}

\section{APÊNDICE A - Carta-convite para participação da pesquisa}

São Paulo, 25 de fevereiro de 2019.

Prezada Senhora,

Tenho a satisfação de apresentar Verônica Reis Cristo, aluna regularmente matriculada no Programa de Ciências da Comunicação, área Interfaces Sociais da Comunicação, Registro USP 4904005, em nível de Mestrado, na Escola de Comunicações e Artes (ECA) da Universidade de São Paulo (USP).

Verônica Reis Cristo é minha orientanda e está desenvolvendo sua pesquisa de mestrado sobre "A comunicação em negócios sociais", que tem como objetivo identificar o papel exercido pela comunicação organizacional em negócios sociais e quais os seus impactos em ações ligadas diretamente à sustentabilidade e aos seus objetivos sociais. Para que a mestranda possa viabilizar a pesquisa aplicada, solicito o apoio imprescindível dessa organização, autorizando-a a realizar entrevistas com seus colaboradores e empreendedores de negócios sociais acelerados.

Desde já agradeço pela atenção de V.Sa. e me coloco à disposição para outras informações que se fizerem necessárias.

Cordiais saudações,

Profa. Dra. Margarida Maria Krohling Kunsch

Orientadora

Ilma. Sra. Anna de Souza Aranha

Diretora da Associação Quintessa 


\section{APÊNDICE B - Roteiro para entrevista com o Quintessa}

\section{Identificação da aceleradora}

Nome:

Ano de criação:

Número de negócios acelerados:

Número de funcionários:

Serviços oferecidos:

Localização:

\section{Identificação do entrevistado}

Nome:

Contatos:

Cargo:

Tempo de empresa:

Escolaridade/área de formação:

Breve história profissional:

Descrição das atividades na empresa:

\section{Sobre a comunicação do Quintessa}

1. Como o Quintessa está organizado, em termos de estrutura e equipes?

2. A aceleradora possui uma área de comunicação?

3. Em caso positivo, a qual área da aceleradora a comunicação é vinculada?

4. Quantas pessoas trabalham na área de comunicação? Quando ela foi criada e com qual objetivo inicial?

5. Como avalia ser a comunicação do seu negócio?

6. Como você avalia os investimentos feitos na área de comunicação do seu negócio? Há um orçamento para esta área?

7. Planeja-se ampliar os investimentos de comunicação no curto, médio e longo prazo?

8. Qual é o envolvimento da comunicação nas tomadas de decisão e no planejamento estratégico da aceleradora? 
9. Quais atividades são desenvolvidas pela área de comunicação?

10. Quais são os públicos mais importantes do seu negócio?

11. Quais são as principais ações do seu negócio para comunicação com os seus públicos?

12. Quais são os principais objetivos das ações de comunicação do negócio?

13. Como é avaliado o desempenho da área de comunicação?

14. Como vê os resultados alcançados pela comunicação da aceleradora?

15. Quais são os principais desafios da área de comunicação da aceleradora?

16. Quais são as vantagens e desvantagens de compartilhar um espaço como este da CIVI-CO?

\section{Sobre comunicação e sustentabilidade em negócios sociais}

17. Vi no site que o Quintessa adota os ODS para a seleção de negócios acelerados. Como a aceleradora define sustentabilidade?

18. A aceleradora possui ações ligadas à sustentabilidade? Quais?

19. Em sua avaliação, como os investidores avaliam a importância dos objetivos sociais e de ações de sustentabilidade em um negócio?

20. Na sua opinião, qual é o papel das aceleradoras de negócios sociais para incentivar ações de sustentabilidade em termos locais e regionais?

21. Na sua avaliação, os negócios sociais são sinônimos de desenvolvimento sustentável? Por quê?

22. Na sua opinião, qual é o papel da comunicação em um negócio social? Como a comunicação pode contribuir para o negócio alcançar seus objetivos sociais e financeiros?

23. Quais são as diferenças em relação à comunicação de um negócio tradicional ou outros segmentos em que você atuou?

24. Quais são os principais desafios da comunicação de um negócio social?

25. Qual é a função das aceleradoras para promover uma comunicação que incentive a sustentabilidade nos negócios sociais?

26. Como avalia as estratégias de comunicação adotadas pelos negócios sociais hoje? Quais delas têm se revelado mais eficientes? 
27. Na sua avaliação, a comunicação praticada pelos negócios sociais hoje tem contribuído para incentivar outros empreendedores na tomada de consciência sobre a importância de incluir aspectos sociais em seus empreendimentos?

\section{Sobre os programas de aceleração de negócios sociais}

28. Quais são os principais critérios de seleção de negócios sociais para participação em programas de aceleração?

29. Quais são as principais áreas de impacto dos negócios acelerados?

30. Quais são as principais dificuldades identificadas por você entre os negócios sociais escolhidos para aceleração?

31. Em linhas gerais, como está estruturado o programa de aceleração de negócios sociais (eixos principais, carga horária, principais tópicos)?

32. Quais são os principais diferenciais do seu programa de aceleração em relação a outros no mercado?

33. Quais estratégias são apresentadas aos empreendedores para conciliar objetivos sociais e financeiros de um negócio?

34. A sustentabilidade é abordada em programas de aceleração de novos empreendimentos? De que maneira? São abordados os ODS?

35. A comunicação é abordada em programas de aceleração de novos empreendimentos? E o marketing? De que maneira?

36. Como é feita a avalição dos resultados do programa de aceleração? Há um acompanhamento feito a posteriori com os negócios acelerados? 


\section{APÊNDICE C - Roteiro para entrevista com empreendedores sociais}

\section{Identificação do negócio social}

Nome:

Ano de criação:

Segmento:

Número de funcionários:

Localização:

\section{Dados do entrevistado}

Nome:

Contatos:

Cargo:

Tempo de empresa:

Escolaridade/área de formação:

Breve história de vida do empreendedor:

\section{Caracterização geral do negócio}

1. Qual é a missão do seu negócio?

2. Quais são os objetivos sociais do negócio? Qual problema social quer ajudar a resolver?

3. Quais são os serviços e produtos oferecidos? Qual é o perfil dos clientes?

4. O negócio já participou de programas de aceleração/incubação de negócios sociais? Quais? Em quais fases do negócio?

5. Qual é a sua avaliação da participação do negócio em programas de aceleração de negócios sociais?

6. Como vê o seu negócio daqui a cinco anos?

\section{Sobre os objetivos sociais e as ações de sustentabilidade}

7. Quais são as áreas mais envolvidas com os objetivos sociais do negócio?

8. Você associa a existência de objetivos sociais a melhores resultados para o negócio? Em caso positivo, quais? 
9. Quais são as estratégias adotadas para conciliar objetivos sociais e financeiros do negócio?

10. O negócio possui ações ligadas à sustentabilidade? Quais?

11. Quais áreas do negócio estão envolvidas com as ações de sustentabilidade?

12. [Caso tenha respondido "sim" à pergunta 10] Você associa a existência de ações de sustentabilidade a melhores resultados para o negócio? Em caso positivo, quais?

13. Na sua opinião, qual é a contribuição dos negócios sociais para incentivar ações de sustentabilidade em termos locais e regionais?

\section{Sobre a área de comunicação}

14. Na sua opinião, qual é o papel da comunicação em um negócio social? Como a comunicação pode contribuir para o negócio alcançar seus objetivos sociais e financeiros?

15. Quais são as diferenças em relação à comunicação de um negócio tradicional?

16. Seu negócio possui uma área de comunicação?

17. Em caso positivo, a qual área da empresa a comunicação é vinculada?

18. Quantas pessoas trabalham na área de comunicação? Quando ela foi criada e com qual objetivo inicial?

19. Você descreveria a comunicação do seu negócio como planejada ou ocasional?

20. A área de comunicação do negócio ocupa-se, majoritariamente, com quais aspectos da comunicação (mercadológica, interna e administrativa, e institucional)?

21. Como você avalia os investimentos feitos na área de comunicação do seu negócio?

22. Planeja-se ampliar os investimentos em comunicação?

23. Qual é o envolvimento da comunicação nas tomadas de decisão do negócio?

24. Quais atividades são desenvolvidas pela área de comunicação?

25. Quais são os públicos mais importantes do seu negócio? Classifique-os.

26. Quais são as principais ações do seu negócio para comunicação com os seus públicos? 
27. Quais são os principais objetivos das ações de comunicação do negócio?

28. Qual é o envolvimento da área de comunicação com os objetivos sociais do negócio?

29. Como é avaliado o desempenho da área de comunicação?

30. Como vê os resultados alcançados pela comunicação do seu negócio?

31. Você acredita que a comunicação contribui para os resultados financeiros e sociais do negócio hoje? De que forma?

32. Você acredita que a comunicação feita hoje pelo negócio consegue fazer compreender o que é um negócio social e no que ele se difere de um negócio tradicional?

33. Quais são os principais desafios da comunicação de um negócio social?

34. Você acredita que a comunicação feita hoje pelo seu negócio é capaz de gerar mudanças de comportamento e conscientização da importância da sustentabilidade? 


\section{APÊNDICE D - Termo de consentimento}

Título da pesquisa: “A comunicação integrada em negócios sociais: um estudo aplicado do caso Quintessa"

Pesquisadora: Verônica Reis Cristo. Orientadora: Margarida Maria Krohling Kunsch (ECA/USP)

1. Natureza da pesquisa: você está sendo convidado(a) a participar desta pesquisa, que tem como finalidade compreender o papel exercido pela comunicação organizacional em negócios sociais e quais são os seus impactos em ações ligadas diretamente à sustentabilidade e aos seus objetivos sociais.

2. Participantes da pesquisa: aceleradoras de negócios sociais e negócios sociais acelerados.

3. Envolvimento na pesquisa: ao participar deste estudo, você permite que o pesquisador utilize os dados coletados durante a entrevista para a construção de sua pesquisa de dissertação. Sempre que quiser poderá pedir mais informações sobre a pesquisa por meio do telefone do pesquisador e/ou seu e-mail de contato. Caso deseje, em qualquer momento, desistir da participação do estudo, isto não implicará nenhum prejuízo para você.

4. Sobre as entrevistas: serão gravadas, transcritas e utilizadas única e exclusivamente para fins desta pesquisa.

5. Confidencialidade: sua identificação pessoal não será divulgada em nenhuma publicação sem sua autorização prévia.

6. Benefícios: ao participar desta pesquisa, você não terá nenhum benefício direto. Entretanto, esperamos que este estudo lhe permita refletir sobre os processos de sua organização.

7. Pagamento: você não terá nenhum tipo de despesa para participar desta pesquisa e não receberá nenhum pagamento por sua participação, contribuindo voluntariamente. 
Consentimento Livre e Esclarecido

Tendo em vista os itens apresentados, eu,

$\mathrm{RG} \mathrm{n}^{\mathrm{o}}$

cargo de forma livre e esclarecida, manifesto meu consentimento em participar voluntariamente desta pesquisa. Declaro que recebi cópia deste termo de consentimento e autorizo a realização desta pesquisa e a divulgação dos resultados dos dados obtidos neste estudo.

Organização:

Contato:

Endereço:

São Paulo, de de 2019.

Assinatura do participante da pesquisa

Assinatura do pesquisador 


\section{APÊNDICE E - Negócios acelerados pelo Quintessa}

Quadro 11 - Classificação dos negócios acelerados pelo Quintessa, em termos de contribuição aos ODS

\begin{tabular}{|c|c|c|c|}
\hline ODS & Negócio social acelerado & Segmento de atuação & Descrição \\
\hline \multirow{2}{*}{ 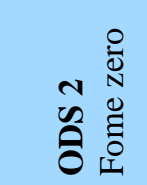 } & Markato Brasil & Alimentação & Alimentação de baixo custo para o consumidor final \\
\hline & Mr. Veggi & Alimentação & Venda de alimentos vegetarianos congelados \\
\hline \multirow{9}{*}{ 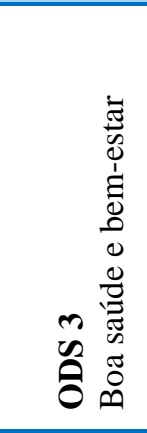 } & Dandelin & Saúde & Desenvolve aplicativo de consultas médicas \\
\hline & Fofuuu & Saúde & Oferece jogos infantis para fonoaudiologia \\
\hline & Heart care & Saúde & Desenvolve aplicativo para monitoramento cardíaco \\
\hline & Hfocus & Saúde & Oferece metodologia de pesquisa para pacientes \\
\hline & Popfisio & Saúde & Serviços de fisioterapia de baixo custo \\
\hline & Telavita & Saúde & Plataforma para conectar pacientes e psicólogos \\
\hline & TNH Health & Saúde & Oferece tecnologias para a gestão de serviços de saúde \\
\hline & UniverSaúde & Saúde & Oferece tecnologias de apoio à gestão de saúde \\
\hline & Ver bem & Saúde & Venda de óculos de baixo custo para base da pirâmide \\
\hline \multirow{11}{*}{ 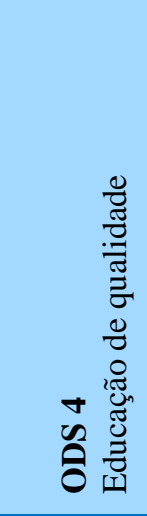 } & 4YOU2 & Educação & Curso de inglês de baixo custo para a base da pirâmide \\
\hline & A Banca & Arte e cultura & Produtora cultural de incentivo à cultura do hip hop \\
\hline & A Taba & Educação & Curadoria de livros infantis \\
\hline & Banca do Bem & Editorial, livraria e papelaria & Produção de livros e revistas. Quem compra uma obra ajuda em uma causa. \\
\hline & Bombelêla & Arte e cultura & Escola de dança \\
\hline & Catraca Livre & Editorial, livraria e papelaria & Guia de programação cultural gratuita de São Paulo \\
\hline & Coruja Educação & Educação & Oferece material didático on-line para escolas, pais e professores \\
\hline & Electi & Educação & Desenvolve metodologia de ensino com incentivo ao impacto social \\
\hline & Elos Educacional & Educação & Consultoria educacional para educadores \\
\hline & Escola mais & Educação & Escola de baixo custo \\
\hline & Imaginie & Educação & Oferece reforço em redação por plataforma eletrônica \\
\hline
\end{tabular}


Quadro 11 - Continuação

\begin{tabular}{|c|c|c|c|}
\hline ODS & Negócio social acelerado & Segmento de atuação & Descrição \\
\hline \multirow{7}{*}{ 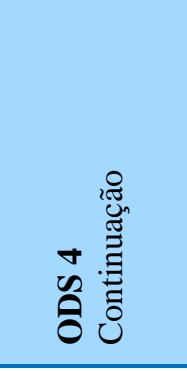 } & Instituto Elos & Educação & Desenvolve projetos de estímulo ao desenvolvimento e mobilização locais \\
\hline & Magia de ler & Educação & Não localizado \\
\hline & Nave a vela & Educação & $\begin{array}{l}\text { Metodologia de ensino para escolas; incentivo à cultura "mão na massa" nas escolas, } \\
\text { com projetos e resolução de problemas }\end{array}$ \\
\hline & Neuro saber & Educação & Oferece cursos sobre desenvolvimento infantil \\
\hline & Projeto Redação & Educação & Plataforma on-line para correção de redações \\
\hline & Qmágico (Eduquo) & Educação & Oferece soluções de base tecnológica para escolas \\
\hline & Stoodi & Educação & Cursinho on-line \\
\hline 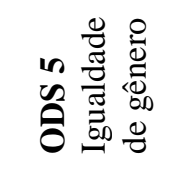 & Nina & Transporte & Tecnologia para rastrear casos de assédio no trânsito \\
\hline 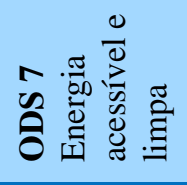 & Emap Solar & Energia & Consultoria e engenharia de energias renováveis \\
\hline$\stackrel{8}{7}$ & Catarina Mina & Têxtil, vestuário e acessórios & Venda de bolsas artesanais \\
\hline ๑ & Escola do Mecânico & Empregabilidade & Oferece cursos de formação para mecânicos \\
\hline .50 & Feira Preta & Empregabilidade & Feira cultural em apoio ao empreendedor negro \\
\hline 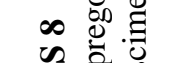 & Já entendi & Educação & Oferece cursos de formação profissional para a base da pirâmide \\
\hline อิ ઘี & Joaquina Brasil & Têxtil, vestuário e acessórios & Moda sustentável e inclusiva, produzida por egressas do sistema prisional \\
\hline
\end{tabular}


Quadro 11 - Continuação

\begin{tabular}{|c|c|c|c|}
\hline ODS & Negócio social acelerado & Segmento de atuação & Descrição \\
\hline \multirow{5}{*}{ 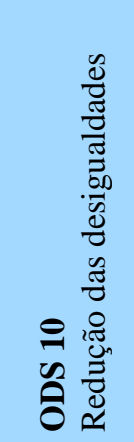 } & Consolidar & Apoio a empreendimentos & Desenvolve programas de inclusão e diversidade nas organizações \\
\hline & Hand talk & Educação & Desenvolve tecnologia de tradução automática para libras \\
\hline & Idasul & Têxtil, vestuário e acessórios & Moda da periferia \\
\hline & Portabilis & Educação & $\begin{array}{l}\text { Desenvolve tecnologias de apoio na gestão de políticas públicas em educação e } \\
\text { assistência social }\end{array}$ \\
\hline & Terra Nova & Gestão comunitária & Atua na regularização fundiária \\
\hline \multirow{8}{*}{ 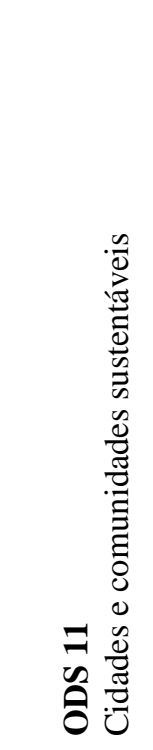 } & Courrieiros & Transporte & Entregadores de bicicleta \\
\hline & E-Moving & Transporte & Aluguel de bikes elétricas \\
\hline & Instituto Cidade Jardim & $\begin{array}{l}\text { Agricultura, pecuária ou } \\
\text { agroindústria }\end{array}$ & $\begin{array}{l}\text { Ações de agricultura urbana, horticultura e engenharia com jardins suspensos e } \\
\text { telhados verdes }\end{array}$ \\
\hline & Lumen & Transporte & Serviços de logística e transporte \\
\hline & Mestres da reforma & Construção e imobiliária & Plataforma que conecta profissionais de obras e clientes \\
\hline & Moradigna & Construção e imobiliária & Oferece serviços de reformas de baixo custo \\
\hline & Pé de Feijão & $\begin{array}{l}\text { Agricultura, pecuária ou } \\
\text { agroindústria }\end{array}$ & Busca estimular a educação ambiental com projetos de hortas urbanas \\
\hline & Sala 2 & Construção e imobiliária & Escritório de arquitetura \\
\hline
\end{tabular}


Quadro 11 - Conclusão

\begin{tabular}{|c|c|c|c|}
\hline ODS & Negócio social acelerado & Segmento de atuação & Descrição \\
\hline \multirow{9}{*}{ 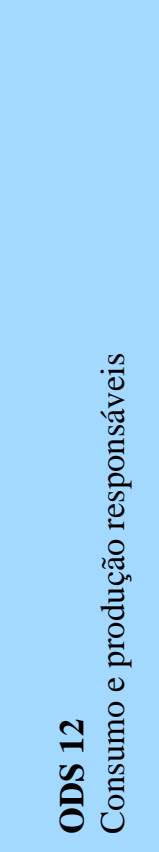 } & Boomera & Reciclagem & Desenvolve programas de gestão de resíduos e economia circular \\
\hline & Fruta imperfeita & Alimentação & $\begin{array}{l}\text { Busca evitar o desperdício de alimentos. Usuário recebe cesta com produtos } \\
\text { imperfeitos que seriam descartados }\end{array}$ \\
\hline & Grupo Gaia & $\begin{array}{l}\text { Agricultura, pecuária ou } \\
\text { agroindústria }\end{array}$ & Realiza o diagnóstico e planejamento para uso de recursos naturais \\
\hline & Instituto Muda & Reciclagem & Desenvolve programas de gestão de resíduos em condomínios \\
\hline & Irys & Produtos sustentáveis & Desenvolve e vende produtos de limpeza sustentáveis \\
\hline & Nossa nova & Produtos sustentáveis & Loja on-line de produtos sustentáveis \\
\hline & Plantverde & $\begin{array}{l}\text { Agricultura, pecuária ou } \\
\text { agroindústria }\end{array}$ & Atua na recuperação de áreas degradadas \\
\hline & Recicleiros & Reciclagem & Desenvolve programas de gestão sustentável de resíduos sólidos \\
\hline & Soma & Reciclagem & Programa de pontos e recompensa por ações de reciclagem \\
\hline & CAUSE & Apoio a empreendimentos & $\begin{array}{l}\text { Agência de comunicação que desenvolve programas para negócios que querem apoiar } \\
\text { causas }\end{array}$ \\
\hline$\overline{0}$ & Impact Hub & Apoio a empreendimentos & Aceleradora e coworking de impacto social \\
\hline$\sim . \stackrel{0}{ \pm}$ & Move social & Gestão comunitária & Apoio na gestão de soluções de impacto \\
\hline 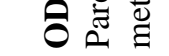 & Sistema B & Apoio a empreendimentos & Busca impulsionar práticas de governança corporativa com enfoque socioambiental \\
\hline
\end{tabular}

Fonte: Elaborado pela autora. 